UNIVERSIDADE DE SÃO PAULO

FACULDADE DE FILOSOFIA, LETRAS E CIÊNCIAS HUMANAS DEPARTAMENTO DE LETRAS CLÁSSICAS E VERNÁCULAS PROGRAMA DE PÓS-GRADUAÇÃO EM ESTUDOS COMPARADOS DE LITERATURAS DE LÍNGUA PORTUGUESA

DONIZETH APARECIDO DOS SANTOS

Sagas familiares e narrativas de fundação engajadas de Erico Verissimo e Pepetela 
UNIVERSIDADE DE SÃO PAULO

FACULDADE DE FILOSOFIA, LETRAS E CIÊNCIAS HUMANAS

DEPARTAMENTO DE LETRAS CLÁSSICAS E VERNÁCULAS

PROGRAMA DE PÓS-GRADUAÇÃO EM ESTUDOS COMPARADOS

DE LITERATURAS DE LÍNGUA PORTUGUESA

Sagas familiares e narrativas de fundação engajadas de Erico Verissimo e Pepetela

Donizeth Aparecido dos Santos

Tese de doutorado apresentada ao Programa de Pósgraduação em Estudos Comparados de Literaturas de Língua Portuguesa do Departamento de Letras Clássicas e Vernáculas da Faculdade de Filosofia, Letras e Ciências Humanas da Universidade de São Paulo (USP).

Orientadora; Prof ${ }^{\mathrm{a}}$. Dr ${ }^{\mathrm{a}}$ Tania Celestino de Macêdo

De acordo:

Prof $^{a}$ Dr $^{a}$ Tania Celestino de Macêdo

São Paulo

2013

VERSÃO CORRIGIDA 


\section{Sagas familiares e narrativas de fundação engajadas de Erico Verissimo e Pepetela}

Tese de doutorado apresentada ao Programa de Pósgraduação em Estudos Comparados de Literaturas de Língua Portuguesa do Departamento de Letras Clássicas e Vernáculas da Faculdade de Filosofia, Letras e Ciências Humanas da Universidade de São Paulo (USP).

Orientadora; Prof ${ }^{\mathrm{a}}$. Dr ${ }^{\mathrm{a}}$ Tania Celestino de Macêdo

\section{BANCA EXAMINADORA}

Professor (a) doutor (a):

Instituição: Assinatura:

Professor (a) doutor (a):

Instituição: Assinatura:

Professor (a) doutor (a):

Instituição: Assinatura:

Professor (a) doutor (a):

Instituição: Assinatura:

Professor (a) doutor (a):

Instituição: Assinatura:

Professor (a) doutor (a):

Instituição: Assinatura: 
DEDICATÓRIA

Para minha mãe, com saudade... 


\section{AGRADECIMENTOS}

À Jane, Felipe e Fernanda, pela compreensão da minha ausência-presença durante os últimos cinco anos.

Ao meu pai, por ter me conscientizado da importância de estudar.

À professora Tania Macêdo, minha orientadora, por ter acreditado em mim e no projeto.

Ao professor Sérgio Adolfo, por ter me mostrado a beleza das literaturas africanas de língua portuguesa.

Aos professores da banca do exame de qualificação e da banca de defesa, Anita Moraes, Rosângela Sarteshi, Mário César Lugarinho e Rejane Vechia, pelas valiosas observações feitas.

À minha amiga Reny, pela revisão ortográfica.

À Stella, pela tradução do resumo para o inglês.

À Roseli e Júlio, da Secretária de Pós-graduação, pela atenção. 


\section{RESUMO}

Esta tese apresenta um estudo comparativo entre a trilogia $O$ tempo e o vento, formada pelos romances $O$ continente (1995), $O$ retrato (1995) e $O$ arquipélago (1995), do escritor brasileiro Erico Verissimo; e o romance Yaka (1998), do escritor angolano Artur Carlos Maurício Pestana dos Santos, conhecido como Pepetela, pelo fato dos dois escritores se utilizarem de estratégias narrativas comuns, tais como a saga familiar, a metaficção, a técnica narrativa do contraponto e a polifonia na escrita de seus romances históricos ou narrativas de fundação. A utilização de recursos narrativos comuns torna semelhantes as estruturas narrativas das duas obras que formam o corpus da pesquisa. Ao final da tese, esperamos comprovar que a obra do escritor brasileiro serviu de modelo para o escritor angolano, que incorporou algumas de suas estratégias narrativas e as adaptou ao contexto da literatura angolana, segundo o conceito de intertextualidade de Julia Kristeva (1974) que concebe a escrita de um texto literário como a leitura do corpus anterior, noção que implica ver o texto como absorção e transformação de um outro texto, de modo que o romancista ao escrever a sua obra sempre parte de um modelo pré-existente, seja para legitimá-lo ou questioná-lo, sem que isto signifique que ele tenha feito uma mera cópia do modelo apropriado.

Palavras-chave: Literatura comparada, Literaturas de língua portuguesa, Literatura engajada, Narrativas de fundação, Sagas familiares 


\begin{abstract}
This thesis presents a comparative study of the trilogy $O$ tempo e o vento,formed by the novels $O$ Continente (1995), $O$ retrato (1995) and $O$ Arquipélago(1995), by the Brazilian writer ÉricoVerissimo, and the novelYaka (1998), by the Angolan writer Artur Carlos Maurício Pestana dos Santos, known as Pepetela, by the fact of the two writers use common narrative strategies, such as family saga, a metafiction, the counterpoint narrative technique and polyphony in their historical novels writing and founding narratives. The use of narrative resources makessimilar the narrative structures of the two works that compose the corpus of this research. At the end of the thesis, we hope to prove that the work of Brazilian writer served as a model for the Angolan writer, which incorporated some of his narrative strategies and adapted them to the context of the Angolan literature, according to the concept of intertextuality of Julia Kristeva (1974) that conceives writing a literary text as the reading of previous corpus notion that implies seeing the text as absorption and transformation of another text, so that the novelist, at the time he writes his work, always parts of a pre-existing model, in order to legitimize it or question it, without this implying that he has made a mere copy of the appropriate model.
\end{abstract}

Keywords: Comparative Literature, Portuguese Language Literature, Engaged Literature, Founding Narratives, Family Sagas. 


\section{SUMÁRIO}

INTRODUÇÃO

1. LITERATURA E ENGAJAMENTO ÉTICO E ESTÉTICO 19

1.1. A função social da literatura 19

1.2. A função social do escritor 24

1.3. O engajamento literário $\quad 28$

1.4. Literatura de engajamento, literatura militante e literatura engajada $\quad 37$

1.5. O romance engajado do século $X X$

1.6. O romance engajado de língua portuguesa 56

1.7. A intertextualidade nos romances engajados de língua portuguesa 66

1.8. Marcas reformuladas pela posteridade: Erico Veríssimo e Pepetela 72

1.9. Gênero, tema e estratégias narrativas comuns utilizadas por Erico 76

Veríssimo e Pepetela

$\begin{array}{ll}\text { 1.9.1. A saga familiar } & 77\end{array}$

$\begin{array}{ll}\text { 1.9.2. Narrativas de fundação } & 78\end{array}$

$\begin{array}{ll}\text { 1.9.3. O contraponto } & 79\end{array}$

$\begin{array}{ll}\text { 1.9.4. A polifonia } & 81\end{array}$

1.9.5. A metaficção $\quad 83$

2. O PROJETO LITERÁRIO DE ERICO VERISSIMO 86

3. A TRILOGIA $O$ TEMPO E $O$ VENTO: UMA SAGA FAMILIAR E

UMA NARRATIVA DE FUNDAÇÃO ENGAJADA 
3.2. As estratégias narrativas utilizadas para a desmitificação da história

3.2.2.2. A família Caré como contraponto à família Terra-Cambará e à história oficial

3.2.3. A polifonia

3.2.3.1. A desmitificação da guerra

3.2.3.2. A desconstrução do mito da democracia racial gaúcha

4.2. Duas peças de teatro pelo caminho FUNDAÇÃO ENGAJADA

5.1. Uma narrativa de fundação engajada

5.2. As estratégias narrativas utilizadas para contar uma outra história 
5.2.3. A polifonia

5.2.4. A metaficção

262

CONCLUSÃO

REFERÊNCIAS BIBLIOGRÁFICAS 


\section{INTRODUÇÃO}

A ideia inicial do projeto de realizar um estudo comparativo entre as obras literárias de Erico Verissimo e Pepetela nasceu em 2003, durante as aulas de Literaturas africanas de língua portuguesa do Programa de pós-graduação da Universidade Estadual de Londrina (UEL), quando fizemos a leitura de Yaka $(1998)^{1}$, a pedido do professor Sérgio Adolfo. A leitura do romance se tornou uma revelação, pois, até então, entre as obras de Pepetela, conhecia apenas As aventuras de Ngunga (1981).

Durante a leitura, fomos prazerosamente percebendo as diversas semelhanças que o romance angolano tinha com O tempo e o vento ${ }^{2}(1995 \mathrm{~h}, \mathrm{j}, \mathrm{g})$, de Erico Verissimo: o gênero, um romance histórico que é também um romance de fundação; a saga familiar, a história sendo contada e vista por várias gerações de uma mesma família; o sapalalo, o casarão colonial de madeira de dois andares onde reside a família protagonista, que lembrava muito o sobrado dos Terra-Cambará; o uso da técnica do contraponto, com a inserção da história de uma família que está na contramão da história narrada, a família cuvale de Vilonda, cujo papel na narrativa equivale ao dos Caré, de O tempo e o vento, como uma antissaga familiar, contrastando com a história da família protagonista; a metaficção presente a partir da metade do romance através da autobiografia que o protagonista Alexandre Semedo estava escrevendo, revelação que nos fazia crer que grande parte do romance que estávamos lendo fazia parte do livro da personagem, caracterizando-se como uma mise em abyme, muito semelhante a que ocorre no volume final da trilogia de Erico Verissimo, onde a personagem Floriano Cambará é o autor do romance da qual faz parte; e por último, a polifonia elaborada

\footnotetext{
${ }^{1}$ As datas citadas entre parênteses após os títulos das obras serão as das edições utilizadas nesta tese. No entanto, alertamos que o faremos somente na primeira vez em que a obra for citada, nas demais citações aparecerá apenas o título, a não ser nos casos em que for citação textual direta.

${ }^{2}$ Trilogia formada pelos romances $O$ continente (1995h), O retrato (1995j) e O arquipélago (1995g).
} 
de uma forma parecida com o contraponto de Verissimo, pois a multiplicidade de narradores faz com que vejamos um mesmo assunto sempre por duas ou mais perspectivas, com destaque para a voz narrativa da estátua yaka, que narra a história colonial pela perspectiva daqueles que não figuram na história principal, tal qual nos interlúdios de $O$ continente, em que há um coro geral dos excluídos. Era algo tão parecido com $O$ tempo e o vento, por causa do processo de composição, mas ao mesmo tempo era tão diferente por conta da matéria literária angolana abordada no romance.

No entanto, naquela época já estávamos com o projeto de dissertação de mestrado definido e com a pesquisa em andamento, e por essa razão, e também pela incerteza e receio da empreitada, a comparação entre os dois escritores ficou adiada. Mas, com a empolgação gerada por Yaka, não deixamos de ler Pepetela e passamos à leitura de outros de seus romances e nosso entusiasmo com obra literária dele foi aumentando cada vez mais. No decorrer de nossas leituras fomos encontrando outros elementos convergentes com a obra de Erico Verissimo. Em Mayombe (1982), a discussão política sobre a revolução e o papel do intelectual que Pepetela fez nesse romance nos lembrou muito a que foi feita por Erico Verissimo em $O$ senhor embaixador $(1995 \mathrm{~m})^{3}$, além de que a polifonia presente nas duas obras também apresenta algumas semelhanças, como, por exemplo, a democratização da narrativa, que explicita as diferentes visões de mundo das personagens; e em Lueji, o nascimento dum império (1997), encontramos o mesmo processo de construção de $O$ tempo e o vento, com a utilização de dois tempos históricos, um tempo diacrônico e outro sincrônico, com duas histórias separadas por quatro séculos se espelhando e se dialogando o tempo todo, além do fato de essa obra ser também uma narrativa de fundação, uma saga familiar e conter uma personagem-romancista, que se revela como o autor do próprio romance no qual está inserido, tal qual Floriano Cambará de $O$ tempo o vento.

\footnotetext{
${ }^{3}$ A nossa reflexão sobre este ponto convergente da obra dos dois escritores deu origem ao artigo "Os intelectuais e a revolução: uma análise das personagens de Erico Verissimo e Pepetela", publicado pela Revista Crioula, v. 3, 2008.
} 
Em 2006, depois de concluído o curso de mestrado e de ter passado por um período de um ano de inatividade acadêmica, retomamos a ideia do estudo comparativo entre os dois escritores, visando abordá-lo numa futura tese de doutorado. Pelas nossas leituras de artigos de vários professores da área de literaturas africanas de língua portuguesa e de entrevistas de escritores angolanos, sabíamos que Erico Verissimo fora lido em Angola juntamente com outros escritores modernistas brasileiros. Mas havia uma grande dúvida: Pepetela teria lido Erico Verissimo e incorporado algumas de suas técnicas narrativas para a elaboração das suas narrativas de fundação? Ou teria sido apenas uma coincidência ambos utilizarem estratégias narrativas muito semelhantes? A resposta veio ainda em 2006: no início de Portanto... Pepetela (2002), livro de fortuna crítica do autor angolano, organizado pelas professoras Rita Chaves e Tania Macêdo, encontramos o fragmento de uma entrevista de Pepetela concedida ao jornalista Wilson Bueno, do jornal O Estado de São Paulo, no qual ele revela ter lido e sido influenciado por Erico Verissimo, Jorge Amado, Graciliano Ramos, José Lins do Rego e João Ubaldo Ribeiro, romancistas brasileiros que ele considera como sendo seus mestres.

Dissipada a dúvida, a partir de 2007, começamos a elaborar o projeto, que sofreu várias alterações no decorrer deste tempo. A mais significativa delas foi a exclusão de Lueji, o nascimento dum império, que constava no corpus quase desde o início da pesquisa, por causa da extensão da tese. No entanto, na conclusão do trabalho, falaremos um pouco mais sobre essa obra, pelo fato de ela conter duas grandes semelhanças e duas grandes diferenças com $O$ tempo e o vento. Também optamos pela não inclusão de A gloriosa família: o tempo dos flamengos (1999), pois, embora sendo também uma narrativa de fundação e uma saga familiar, os seus processos narrativos se afastam totalmente do modelo fornecido por Erico Verissimo. Por fim, optamos por fazer um estudo comparativo apenas entre $O$ tempo e o vento e Yaka, que corresponde à ideia inicial do projeto. 
Além da apreciação da obra literária de Erico Verissimo e Pepetela, o que nos motivou a empreender esse projeto foi a necessidade de se lançar luz sobre os elementos comuns que algumas de suas obras apresentam e que ainda não foram devidamente observados, e o fato de desconhecermos a existência de qualquer pesquisa envolvendo os dois escritores, mesmo com o significativo aumento dos estudos comparados de literaturas de língua portuguesa nas universidades brasileiras, nas quais há diversos trabalhos concluídos e em andamento envolvendo Pepetela e outros escritores brasileiros, e nenhum envolvendo Erico Verissimo com um autor africano de língua portuguesa, mesmo o escritor gaúcho pertencendo ao grupo de escritores brasileiros cujas obras tiveram grande circulação e impacto em Angola e Moçambique, conforme veremos na parte final do primeiro capítulo.

Uma hipótese coerente para essa ausência de estudos literários aproximando Erico com escritores africanos de língua portuguesa pode ser formulada a partir da observação feita por Angel Rama (2001, p.282), que considera que o estado natal de Erico Verissimo, o Rio Grande do Sul, "mostra vínculos maiores com o Uruguai, ou a região argentina dos pampas, do que com o Mato Grosso ou o Nordeste de seu próprio país”, pensamento semelhante ao de Antonio Candido (2006, p. 242), para quem a produção literária desse estado "possui traços característicos, que por vezes a aproximam mais da literatura gauchesca rioplatense que do romance urbano do Rio de Janeiro". Essa diferenciação da cultura e da literatura do Rio Grande do Sul em relação às regiões brasileiras que apresentam mais afinidades com os países africanos de língua portuguesa é uma possível explicação para a inexistência de estudos comparativos entre obras de Erico Verissimo e obras de escritores africanos. Nesse sentido, essa análise comparativa procura mostrar que, apesar de não haver quase nenhuma afinidade cultural entre o Rio Grande do Sul e Angola, há afinidades ideológica e estética entre Pepetela e Erico Verissimo. 
Dessa forma, essa tese apresenta um estudo comparativo entre a trilogia $O$ tempo e $o$ vento, formada pelos romances $O$ continente, $O$ retrato e $O$ arquipélago, do escritor brasileiro, e o romance Yaka, do escritor angolano, a partir do conceito de intertextualidade concebido por Julia Kristeva, pelo fato dos dois escritores se utilizarem de estratégias narrativas comuns, tais como a saga familiar, a metaficção, a técnica narrativa do contraponto e a polifonia na escrita de seus romances históricos ou romances de fundação. A utilização das mesmas técnicas tornam semelhantes as estruturas narrativas das duas obras que formam o corpus da pesquisa. Ao final da tese, esperamos ter comprovado que a obra literária de Erico Verissimo serviu de modelo para Pepetela, que incorporou algumas de suas estratégias narrativas e as adaptou ao seu projeto literário e ao contexto da literatura angolana.

Desse modo, primeiramente situamos os dois escritores num processo de desenvolvimento da literatura, sem que haja a subordinação da obra de um sobre a de outro, seguindo o pensamento de Julia Kristeva (1974), para quem a escrita de um texto literário é a leitura do corpus anterior, noção que implica ver o texto como absorção e transformação de um outro texto, de forma que o romancista ao escrever a sua obra sempre parte de um modelo pré-existente, seja para legitimá-lo ou questioná-lo, sem que isto signifique que ele tenha feito uma mera cópia do modelo apropriado.

Para tanto, considerando tanto Erico Verissimo quanto Pepetela como escritores engajados, conforme o conceito de engajamento literário pensado e teorizado por Jean-Paul Sartre (2006), no primeiro capítulo, intitulado "Literatura e engajamento ético e estético", fazemos uma abordagem vertical da literatura engajada, analisando, principalmente, a função social da literatura e do escritor, a teorização do engajamento realizada por Sartre, a definição do conceito de literatura engajada feita por Benoît Denis (2002), o diálogo intertextual que houve nas primeiras décadas do século XX entre romances e romancistas engajados devido às grandes afinidades estéticas e ideológicas entre eles, até chegarmos à análise da 
intertextualidade entre os romancistas de língua portuguesa, onde situamos Erico Verissimo e Pepetela como herdeiros da tradição da literatura engajada surgida no período do entreguerras. Embora haja um hiato temporal entre o período de produção literária dos dois autores, nos apoiamos na tese de Edvaldo Bergamo (2008) de que o romance engajado das décadas de 30 e 40 do século passado deixou marcas que foram aproveitadas e reformuladas pela posteridade. Dentre elas, apresentamos algumas marcas temáticas e formais da literatura do romancista brasileiro que foram apropriadas e reformuladas pelo romancista angolano já na década de 80 . Neste capítulo nos servimos, principalmente, do respaldo teórico de Antonio Candido (1972, 2000), Alejo Carpentier (1971), Jean-Paul Sartre (1994, 2006), Edward Said (2005), Benoît Denis (2002), Julia Kristeva (1974), Mikhail Bakhtin (1997), Irving Howe (1998), Alfredo Bosi (2008), Benjamin Abdala Júnior (2007) e Edvaldo Bergamo (2008).

No segundo capítulo, "O projeto literário de Erico Verissimo", verificamos como é realizado o "corte transversal da sociedade" pretendido pelo escritor gaúcho, desde a primeira obra publicada, Fantoches em 1932, até a última, Incidente em Antares em 1971, verificando também como se dá a conciliação do elemento ético com o estético em suas obras literárias, condição que as fazem engajadas. Neste capítulo nos amparamos nos escritos de Antonio Candido (1972b, 2000, 2004a), Álvaro Lins (1963), Wilson Martins (1977), Flávio Loureiro Chaves (1972, 2001), Maria da Glória Bordini (1985, 1995, 1997, 2003), Silviano Santiago (2005), Moysés Vellinho (2005), Massaud Moisés (2009), Tristão de Athayde (1972), Fábio Lucas (1972), Gilberto Mendonça Telles (1979), Ana Letíca Fauri (2005), Márcia Ivana de Lima e Silva (2000), Joaquim Rodriguez Suro (1985), Guilhermino César (1972) e Daniel Fresnot (1977).

No capítulo seguinte, "A trilogia $O$ tempo e o vento: uma saga familiar e uma narrativa de fundação engajada", abordamos a principal obra literária de Erico Verissimo a partir dos pontos em que acreditamos, conforme a proposta desta tese, que foram apropriados e 
adaptados ao contexto literário angolano por Pepetela, levando-se em conta também a coerência dessa obra com o seu projeto literário de realizar um corte transversal da sociedade. Desse modo, abordamos $O$ tempo e o vento como uma narrativa de fundação engajada, em que o escritor gaúcho acrescenta elementos do engajamento literário do século $\mathrm{XX}$ ao modelo de romance de fundação do século XIX; como uma saga familiar, em que o destino da família Terra-Cambará se entrelaça à história da formação do Rio Grande do Sul e, em certa medida, também do Brasil; e a utilização das técnicas narrativas do contraponto, da polifonia e da metaficção como estratégias narrativas para desmitificar a história oficial gaúcha, conforme previa o projeto da escrita da trilogia. Além de alguns autores já citados, nos valemos neste capítulo dos estudos de Tzvetan Todorov (1976), Gerard Genette (1976), Paul Ricouer (2010), Georg Lukács (1966), Fernando Ainsa (1991), Seymour Menton (1993), Fredric Jameson (2007), Linda Hutcheon (1984, 1991), Lucia Helena (2005), Regina Zilberman (2000, 2004), Alcmeno Bastos (2000) e Hermógenes Saviani Filho (2008).

No quarto capítulo, "O projeto literário de Pepetela", fazemos uma abordagem similar à realizada no segundo capítulo. Acompanhamos o percurso literário do escritor angolano desde o seu primeiro romance escrito, Muana Puó em 1969, até a sua mais recente publicação, A sul. O sombreiro, romance publicado no final de 2011, verificando a dupla face que o seu projeto literário comporta: a tematização da formação da nação angolana, reescrevendo a história do país através da ficção, dando voz a tudo que ficou silenciado nos desvãos da história colonial, e ao mesmo tempo questionando todo esse processo, inserindo no texto literário uma crítica contundente tanto às estruturas de poder colonial quanto às novas estruturas de poder que se estão a construir, com o objetivo de levar os seus leitores à reflexão. Verificamos também como a radicalidade ética do seu projeto literário é acompanhada pela radicalidade estética. Neste capítulo utilizamos como base para a nossa argumentação os trabalhos de Michel Laban (1991), Rita Chaves (1999, 2005), Tania 
Macêdo (2002, 2006), Pires Laranjeira (1995), Vima Lima Martin (2002, 2009), Fernando Martinho (2002), Helena Riaúzova (1986), Alberto de Oliveira Pinto (2002), Maria Tereza Salgado (2002), Célia Marinângelo (2002), Maria Thereza Abelha Alves (2002), Carmen Lúcia Tindó Ribeiro Secco (2002), Magdala França Vianna (2002), Valéria Teixeira (2002), Ana Mafalda Leite (2002), Ana Luisa Ventura Pereira (2009), Rosangela Manhas Mantolvani (2009) e Simone Caputo Gomes (2009).

No quinto capítulo, "Yaka: uma saga familiar e uma narrativa de fundação engajada", abordamos o romance de Pepetela a partir dos mesmos pontos abordados em O tempo e o vento, os quais acreditamos que foram apropriados e adaptados por Pepetela ao contexto literário angolano e ao seu projeto literário. Ou seja, abordamos Yaka como uma narrativa de fundação que contém elementos do engajamento literário do século $\mathrm{XX}$; como uma saga familiar, em que o destino da família Semedo se entrelaça à história da formação de Angola; e analisamos a utilização das técnicas narrativas do contraponto, da polifonia e da metaficção como estratégias narrativas para contar a história do colonialismo português em Angola pelo ponto de vista do povo angolano, contrastando-a com a história oficial; fazer uma análise da sociedade colonial angolana; dar voz aos excluídos e silenciados pela história e mostrar diferentes pontos de vista sobre um mesmo assunto. Neste capítulo, além de alguns autores já citados no embasamento dos capítulos anteriores, nos valemos também das obras de Benedict Anderson (2008), Edward Said (1995), Frantz Fanon (1979), Albert Memmi (1969), Hayden White (1995), Mikhail Bakhtin (1998), Mário César Lugarinho (2007), Carlos Serrano (1999), Antonio Roberto Esteves (1995), Inocência Mata (1982, 2000) e Maria Aparecida Santilli (2002).

Finalmente, na conclusão da tese, analisamos as diferenças no modo de utilização dessas estratégias narrativas pelos dois autores, e ao final esperamos ter comprovado que esses recursos narrativos, ou pelo menos a maioria deles, utilizados inicialmente por Erico 
Verissimo foram incorporados e adaptados por Pepetela ao seu projeto literário e ao contexto literário angolano.

Em tempo, esclarecemos que nos capítulos 3 e 5 nos referimos a $O$ tempo e o vento e Yaka como narrativas que possuem uma forma de representação literária típica do romance histórico tradicional, conforme a teorização feita por Georg Lukács (1996), pelo fato de elas se utilizarem de uma família totalmente fictícia para a análise dos acontecimentos históricos abordados, mostrando como essas personagens foram afetadas e como reagiram a determinados acontecimentos históricos, enquanto que as personagens históricas compõem o pano de fundo da narrativa, recuperando, dessa forma, a singularidade histórica de uma época atravessada por diversas crises históricas que condicionam a vida dos indivíduos em sociedade. E, por outro lado, também mostramos que essas narrativas, pelo fato de serem engajadas, possuem algumas características do novo romance histórico, conforme o conceito de Fernando Ainsa (1991) e Seymour Menton (1993), assim como alguns traços da metaficção historiográfica de Linda Hutcheon (1991). No entanto, alertamos que essa questão não é aprofundada pelo fato de entendermos que ela fugiria ao nosso objetivo principal e implicaria no aumento da extensão do texto. Desse modo, mostramos que as duas obras se colocam num entre-lugar, conforme o sentido dado a este termo por Silviano Santiago, entre as duas concepções de romance histórico, tendo características tanto de uma quanto de outra.

Esclarecemos também que optamos pela abordagem de $O$ tempo e o vento e Yaka como narrativas de fundação, no sentido definido por Lúcia Helena (2005, p.176) como "um fenômeno híbrido, parte artístico-literário, parte histórico-político, no qual, por meio da ficção, criam-se 'comunidades imaginadas'"4', e não como romances históricos, pelo fato de que a nomenclatura e a definição de "narrativa de fundação" abarca os aspectos ficcional, histórico, político e mítico da narrativa, sem prejuízo ou exclusão de nenhum deles.

\footnotetext{
4 "Comunidade imaginada" é um termo criado por Benedict Anderson (2008) para definir um conceito de nação e analisar os nacionalismos que surgiram a partir do século XIX e que levaram a criação das nações modernas.
} 


\section{LITERATURA E ENGAJAMENTO ÉTICO E ESTÉTICO}

\subsection{A função social da literatura}

Antonio Candido (2000), ao abordar as relações entre literatura e sociedade, afirma que a arte, e por consequência a literatura, que é uma de suas principais manifestações, é social em dois sentidos que se complementam. Primeiro, para ser elaborada ela depende da ação de fatores do meio em que é gerada, que se exprimem na obra artístico-literária em vários graus de sublimação; e depois de concebida e publicada, produz sobre os receptores/leitores um efeito prático, modificando suas condutas e concepções de mundo, ou reforçando neles o sentimento dos valores sociais. Isso acontece, observa ele, em decorrência da própria natureza da arte literária. Outro fator importante é que a relação de influência do meio social sobre os artistas/escritores e do objeto artístico/literário sobre os receptores/leitores, independe do grau de conscientização que ambos possam ter, de modo que ela possa se realizar de forma inconsciente ou subconsciente.

No primeiro desses dois sentidos apontados pelo crítico, sobre o caráter social do objeto artístico, está a sua assertiva de que os elementos sociais, externos à obra literária, tornam-se internos, transformando-se em elementos que desempenham papéis significativos na constituição do texto literário. Ou então, conforme afirma em outro momento, o texto literário se forma a partir do contexto, que dá "lastro às obras e as amarram ao mundo onde vivemos" (CANDIDO, 1972, p. 79). Dessa forma, segundo Candido (2000), uma obra literária é fruto da confluência entre a iniciativa individual do escritor e as condições sociais do ambiente em que está inserido. Assim, para ele, esses dois aspectos da criação literária estão indissoluvelmente ligados: "forças sociais condicionantes guiam o artista em grau maior ou menor. Em primeiro lugar, determinando a ocasião de a obra ser produzida; em segundo, 
julgando da necessidade de ela ser produzida; em terceiro, se vai ou não se tornar um bem coletivo" (CANDIDO, 2000, p. 25).

Quanto aos fatores socioculturais, oriundos dessas forças sociais condicionantes, que influem concretamente na elaboração de uma obra literária, Antonio Candido (Ibid.) observa que é difícil discriminá-los, mas aponta que os mais importantes e decisivos estão ligados à estrutura social, aos valores e ideologias presentes na sociedade e às técnicas de comunicação utilizadas pelo escritor. Desse modo, segundo ele,

O grau e a maneira por que influem estes três grupos de fatores variam, conforme o aspecto considerado no processo artístico. Assim, os primeiros se manifestam mais visivelmente na definição da posição social do artista, ou na configuração de grupos receptores; os segundos, na forma e conteúdo da obra; os terceiros, na sua fatura e transmissão. Eles marcam, em todo caso, os quatro momentos da produção, pois: a) o artista, sob impulso de uma necessidade interior orienta-o segundo os padrões da sua época, b) escolhe certos temas, c) usa certas formas e d) a síntese resultante age sobre o meio. (CANDIDO, 2000, p. 21)

Assim, na teorização de Antonio Candido, a concepção de uma obra literária não é apenas fruto de uma iniciativa individual, isenta de qualquer contágio de elementos externos à estrutura do texto literário, como queriam os estruturalistas e simpatizantes do new criticism, e nem tampouco estaria condicionada a um determinismo do meio e do momento, como pensava a antiga crítica sociológica, e sim da junção desses dois fatores que não se excluem, ou melhor, se complementam. Nesse sentido, a escrita de um romance, de um poema ou de um texto dramático é resultado da inspiração do escritor associada aos fatores socioculturais do meio e da época em que ele está inserido.

No segundo sentido social da arte, identificado por Antonio Candido, encontram-se as funções da literatura, especialmente a sua função social, que, segundo o crítico, "comporta o papel que a obra desempenha no estabelecimento de relações sociais, na satisfação de necessidades espirituais e materiais, na manutenção ou mudança de uma certa ordem na sociedade" (CANDIDO, 2000, p. 46). Embora afirme que essa função independe da vontade e 
da consciência de escritores e leitores, Candido observa que eles quase sempre estabelecem alguns propósitos conscientes, que por sua vez tornam-se uma das camadas de significação do texto literário. Desse modo, o escritor pode querer atingir determinado fim, enquanto que o leitor pode desejar que ele lhe apresente algum aspecto da realidade.

Esse acordo que pode ser preestabelecido entre autor e leitor contribui para o surgimento de uma função ideológica da obra literária, definida pelo crítico como "um desígnio consciente, que pode ser formulado como ideia" (Ibid.), com a ressalva de que isso, muitas vezes, pode ser uma ilusão do escritor, desmentida pelo próprio texto literário que escreveu. A função ideológica, segundo Candido, é menos importante que a função social e a função total ${ }^{5}$ da literatura, e aparece frequentemente englobada nelas, tornando-se mais clara em textos literários que contenham fins políticos, religiosos ou filosóficos.

Essas três funções da literatura analisadas por Antonio Candido em Literatura $e$ sociedade, concebendo o conceito de função como o papel que a obra literária desempenha na sociedade, foram repensadas e ampliadas por ele em A literatura e a formação do homem, conferência proferida na XXIV Reunião Anual da SBPC, realizada em São Paulo em julho de 1972, e publicada nesse mesmo ano pela Revista Ciência e Cultura, com o intuito de mostrar algumas variações sobre uma outra função, a função humanizadora da literatura, que seria o conjunto das três funções anteriormente citadas.

\footnotetext{
${ }^{5}$ Em Literatura e sociedade, Antonio Candido (2000, p.44-47) distingue três funções para a literatura, tomada num sentido amplo da natureza literária: função total, função social e função ideológica. A função total, segundo ele consiste num "sistema simbólico, que transmite certa visão do mundo, por meio de instrumentos expressivos adequados. Ela exprime representações individuais e sociais que transcendem a situação imediata, inscrevendose no patrimônio do grupo". Para exemplificar, lembra a representação da humanidade que há em a Odisseia, um contingente de experiência e beleza que se desprendeu da função social que teria exercido no mundo grego e se fixou no patrimônio da civilização ocidental, tornando-se intemporal e universal. Dessa forma, esta função está ligada à capacidade que uma determinada obra literária tem de comover leitores de diferentes épocas e espaços distantes de onde ela foi elaborada. Sobre as três funções, Candido observa que somente a partir da consideração das três, simultaneamente, é possível compreender a obra literária de maneira equilibrada.
} 
Nesse texto, Candido, entendendo a literatura como força humanizadora que exprime o homem e depois atua na sua própria formação, desdobra e aprofunda as funções total, social e ideológica em função psicológica, formativa e de representação de uma dada realidade social e humana, que juntas formam a função humanizadora que a literatura possui, que por sua vez engloba todas as demais funções concebidas por ele.

Assim a função psicológica, que antes estava embutida na função social e na função total, aparece como a necessidade universal de ficção e fantasia que o ser humano possui, ao lado de outras necessidades vitais como a alimentação e o repouso. Nesse sentido, a obra literária é uma das possibilidades de satisfação dessa necessidade humana, juntamente com outras modalidades de arte e objetos culturais. Segundo Candido,

Por via oral ou visual; sob formas curtas e elementares, ou sob complexas formas extensas, a necessidade de ficção se manifesta a cada instante; aliás, ninguém pode passar um dia sem consumi-la, ainda que sob a forma de palpite na loteria, devaneio, construção ideal ou anedota. E assim se justifica o interesse pela função dessas formas de sistematizar a fantasia, de que a literatura é uma das modalidades mais ricas. (CANDIDO, 1972, p. 81)

Antonio Candido ressalta que essa fantasia quase nunca é pura e, geralmente, se refere a alguns aspectos da realidade concreta do ser humano, sejam eles sentimentos, dramas humanos, acontecimentos sociais e históricos, costumes, fenômenos naturais, paisagens ou desejo de explicação para um fenômeno desconhecido, entre outros. Ou seja, a fantasia que o homem procura no texto artístico/literário nunca é gratuita, ela sempre está alicerçada num dado da realidade, vivenciado ou sonhado por ele, de forma que há um inegável vínculo entre "imaginação literária e realidade concreta do mundo" (CANDIDO, 1972, p. 82).

Essa ligação entre fantasia e realidade, que posteriormente Antonio Candido irá definir como "a combinação adequada de utilidade e gratuidade" (CANDIDO, 1999, p. 105), faz com que a obra literária seja também "a representação de uma dada realidade social e humana", outra função da literatura identificada por ele a partir da função total e da função social, que 
nos remete também à sua assertiva, anteriormente citada, de que os elementos sociais transformam-se em elementos que desempenham papéis significativos na constituição do texto literário.

Pelo fato de a literatura corresponder à necessidade universal de ficção e fantasia do homem e ao mesmo tempo ser uma representação de uma realidade social e humana, Antonio Candido (1972, p. 83) também vê nela uma função formativa, mas não termos pregados pela pedagogia oficial, que ideologicamente se vale de elementos do texto literário que são convenientes à propagação de valores morais e políticos de interesse das classes dominantes. Ao contrário, ele a concebe como algo que possui um alto grau de complexidade, que tanto pode disseminar o bem quanto o mal e por conta disso suscita atitudes ambivalentes em educadores e moralistas que se sentem fascinados pela sua força humanizadora e, ao mesmo tempo, ficam temerosos por conta dos valores contrários aos seus que ela comporta, considerados por eles como elementos de perversão e subversão, que podem contaminar alguns setores da sociedade pensada ou sonhada por eles.

Nesse sentido, para o crítico, a literatura não é um apêndice da instrução moral e cívica pelo simples fato de agir "com o impacto indiscriminado da própria vida e edificar com ela - com altos e baixos, luzes e sombras" (CANDIDO, 1972, p. 83), e, dessa forma, por causa da sua natureza complexa e paradoxal, "ela não corrompe e nem edifica", mas traz em seu bojo aquilo que o ser humano conhece pelos nomes de "bem" e de "mal" e, por essa razão, "humaniza em sentido profundo, porque faz viver" (Ibid., p. 85).

Desse modo, o conceito de literatura de Antonio Candido se constrói a partir da confluência do individual com o coletivo, da fantasia com a realidade, da gratuidade com a utilidade. De forma alguma ele concebe o texto literário constituído só por um desses polos, como um produto apenas da imaginação individual do autor, sem nenhuma influência do mundo exterior, ou apenas como um retrato fiel da realidade coletiva, sem a interferência 
criadora do escritor. Para Candido (1999, p. 105), a literatura enquanto objeto artístico se constitui nesse paradoxo: como "a necessidade universal de dar forma à fantasia para compreender melhor a realidade".

E dessa forma, ela não é apenas um objeto estético gratuito, concebido para fruição dos seus apreciadores para satisfazer a necessidade humana de ficção e fantasia, mas também tem a sua parcela de utilidade, que não é de modo algum pequena, pelo fato da imaginação do escritor representar uma realidade social e humana, e por essa representação possibilitar a autores e leitores uma reflexão sobre o mundo real para compreendê-lo melhor.

\subsection{A função social do escritor}

Se a literatura possui uma função social, o escritor também há de ter um papel definido na sociedade da qual faz parte. Na concepção de literatura de Antonio Candido (2000), conforme vimos anteriormente, uma obra literária para ser elaborada depende da imaginação individual criativa do autor e das condições sociais que determinam a sua posição social. Desse modo, segundo o crítico, numa determinada sociedade, o escritor é um indivíduo que exprime a sua originalidade através da elaboração de um texto literário e, também, é alguém que desempenha "um papel social, ocupando uma posição relativa ao seu grupo profissional e correspondendo a certas expectativas dos leitores ou auditores" (CANDIDO, 2000, p. 74) Partindo desse pressuposto de que o escritor possui uma função na sociedade, vamos procurar verificar em que consiste esse papel que ele deve desempenhar socialmente, com base no pensamento de Jean-Paul Sartre (2006) e Alejo Carpentier (1971).

A função social do escritor foi um tema de constantes debates realizados ao longo do século XX, iniciados ainda no século anterior quando houve a emergência do Realismo 
literário. Sem esquecer que a pessoa física do escritor desempenha outras funções sociais, pois muitos deles antes de serem escritores foram, ou continuaram sendo, também advogados, médicos, fazendeiros, diplomatas, funcionários públicos ou jornalistas, dentre algumas funções possíveis de serem elencadas, o que muito se discutiu foi a importância e a utilidade deles enquanto romancistas, poetas ou dramaturgos e, principalmente, se seus escritos deveriam ou não abordar ou conter crítica social e política.

$\mathrm{Na}$ condição de um dos principais atores desse debate, o filósofo, crítico literário e também romancista, o francês Jean-Paul Sartre (2006, p. 21), afirmava que "a função do escritor é fazer com que ninguém possa ignorar o mundo e considerar-se inocente diante dele". Isso implicava a concepção da escrita literária como "um ofício que exige um aprendizado, um trabalho continuado, consciência profissional e senso de responsabilidade" (Ibid., p. 171), com o objetivo principal de "desvendar o mundo e propô-lo como uma tarefa à generosidade do leitor" (Ibid., p. 49).

Desse modo, Sartre concebia a escrita literária como uma atividade burguesa, o escritor como um funcionário liberal como tantos outros existentes na sociedade, e a obra literária "como um serviço remunerado" (Ibid., p. 87), que, embora estivesse vinculado ao capitalismo burguês e até mesmo dependente dele, deveria, contraditoriamente, atuar contra ele, revelando ao leitor todas as mazelas e injustiças sociais, inclusive, e principalmente, a exploração do homem pelo homem levada a cabo por um sistema econômico perverso, sem ocultar nenhum dos seus aspectos, mesmo os mais sórdidos; isso tudo, é claro, sem perder a sua especificidade de objeto artístico. Nesse sentido, vale lembrar a observação feita por Terry Eagleton sobre a reflexão de Theodor Adorno sobre o estatuto contraditório da obra de arte moderna na sociedade burguesa, que lhe permite ser cúmplice e, ao mesmo tempo, protestar contra a ordem social vigente, como quer Sartre: 
O modernismo é a arte forçada a uma autocontradição silenciosa, e a fonte deste impasse está no estatuto material contraditório da arte na sociedade burguesa. A cultura está profundamente imersa na estrutura de produção de mercadorias. Um dos efeitos disso é o de liberá-la a uma certa autonomia ideológica, permitindo-lhe falar, por exemplo, contra a ordem social da qual ela é culpadamente cúmplice. É esta cumplicidade que leva a arte ao protesto, mas que também torna este protesto sofrido e ineficiente, mais um gesto formal que polêmica consequente. A arte só pode pretender ser válida se carregar implicitamente uma crítica às condições de produção, e se recorda a distância privilegiada que ela guarda dessas condições, esse valor se invalida instantaneamente. Inversamente, a arte só pode ser autêntica se reconhece, silenciosamente, o quão profundamente está comprometida com aquilo a que se opõe; mas, ao levar essa lógica muito longe, enfraquece precisamente a sua autenticidade. (EAGLETON, 1993, p. 252-253)

Embora Eagleton coloque em dúvida a eficiência do protesto realizado pela obra de arte, achamos importante mencionar a sua autonomia ideológica pensada por Adorno, que faz com que ela se oponha àquilo a que está comprometida, pelo fato de que a exploração dessa contradição é o que Sartre pede que os escritores façam.

Na senda aberta por Jean-Paul Sartre, encontram-se também as ideias do cubano Alejo Carpentier (1971), jornalista, diplomata, crítico literário e romancista, que concebia a escrita como um meio de ação só concebível e útil se fosse "em função dos seres aos quais esta ação concerne" (Ibid. p. 91), ou seja, se a ação escrita fosse em prol dos leitores e do mundo em que vivem. Nesse sentido, Carpentier elege como a missão mais elevada do escritor o ato de definir, fixar e mostrar esse mundo aos seus leitores, ou seja, que o desvendasse a eles, como quer Sartre, de modo que esse desvendamento pudesse servir para iluminar suas existências e ajudá-los em suas caminhadas. Dessa forma, ao final do seu ensaio "Papel social do romancista", fruto de uma conferência proferida nos Encontros Internacionais, realizado em Genebra em 1967, no qual cobra mais empenho e participação dos escritores latinoamericanos em face do continente, dos seus países e de seus povos, ele reafirma de forma convicta aquilo que acredita ser a função social do romancista:

Ocupar-se desse mundo, desse pequeno mundo, desse grandíssimo mundo, é a tarefa do romancista atual. Entender-se com ele, com esse povo combatente, criticá-lo, exaltá-lo, pintá-lo, amá-lo, tentar compreendê-lo, 
tentar falar-lhe, falar dele, mostrá-lo, mostrar nele o âmago, os erros, as grandezas e as misérias; falar dele mais e mais aos que permanecem sentados à beira do caminho, inertes, esperando não sei o quê, ou talvez nada, mas que têm, no entanto, necessidade de que se lhes diga alguma coisa para os demover.

Tal é, na minha opinião, a função do romancista atual. Tal é a sua função social. Não pode fazer muito mais, e já é bastante. (CARPENTIER, 1971, p. 95)

Embora reconhecendo as limitações da escrita literária, Carpentier vê na figura do romancista latino-americano alguém com um nobre papel social a cumprir na tarefa da representação de seus povos, de suas nações e de seu continente, que por sua vez contribuísse para um despertar de consciências que pudesse melhorar esse mundo habitado por eles. Para ele, o romancista latino-americano não deveria se alienar e nem alienar seus leitores com seus escritos, e sim mostrar-lhes esse mundo do modo como ele é. A sua receita para o escritor cumprir tal empreendimento, e assim prestar um serviço útil à sociedade, consiste em "em partir do próprio rincão, e subir do particular ao universal" (Ibid., p. 92), orientação de que se apropria de Michel Leiris, para lembrar ao romancista que ele deve sempre começar por suas raízes para depois alcançar a universalidade, pois elas são base de qualquer texto literário que se pretenda tornar universal. Dessa forma, segundo ele, o romancista deveria observar e compreender o seu mundo particular e depois dar uma visão do mundo a ele, sempre partindo do seu "compromisso com esse mundo" (Ibid.).

As ideias de Carpentier sobre o papel social do escritor vão ao encontro daquilo que Terry Eagleton pensa a respeito da tradição estética de esquerda, que, entre outras coisas, concebe a arte como crítica da alienação:

A tradição estética de esquerda, de Schiller e Marx a Morris e Marcuse tem muito a dizer: a arte como crítica da alienação, como realização exemplar de seus poderes criativos, como reconciliação ideal do sujeito e o objeto, do universal e o particular, da liberdade e a necessidade, da teoria e a prática, do indivíduo e a sociedade. (EAGLETON, 1993, p. 266) 
Como vimos, a concepção da escrita literária e, principalmente, do papel social do escritor, teorizada por Jean-Paul Sartre, é comungada também por Alejo Carpentier, que não por acaso foi seu contemporâneo e fez parte do círculo frequentado pelo escritor francês no período em que viveu em Paris, local de intensos debates ideológicos na primeira metade do século XX. Poderíamos também juntar a eles os nomes dos romancistas André Malraux e Albert Camus, escritores que tiveram papel de destaque nas discussões políticas e literárias do período. Ambos, enquanto homens de pensamento que se transformavam em homens de ação através do uso da palavra, foram intelectuais engajados e os seus escritos literários foram coerentes com suas posturas críticas, políticas e teóricas, assim como Jean-Paul Sartre e Alejo Carpentier.

Desse modo, o que Jean-Paul Sartre, Alejo Carpentier, André Malraux e Albert Camus reivindicavam, acima de tudo, era que as obras literárias servissem não apenas para a satisfação da necessidade de ficção e fantasia que o ser humano possui, mas que também tivessem uma função social, que fosse humanizadora e política, e assim pudessem despertar consciências e colaborar para a ocorrência de significativas mudanças sociais que, por sua vez, contribuíssem para o bem-estar do homem. O que esses escritores defendiam, principalmente Sartre, era que a literatura fosse engajada, ou seja, que ela fosse comprometida com os problemas sociopolíticos contemporâneos do autor.

\subsection{O engajamento literário}

Para Jean-Paul Sartre (2006), a literatura deveria ser um ato libertador que contribuísse para a libertação política do homem, através da veiculação de ideias que pudessem provocar transformações sociais, que por sua vez melhorassem a vida do ser humano, pois, sendo ela 
uma atividade intelectual, deve ter por objetivo, como pensa Edward Said (2005, p. 31), "promover a liberdade humana e o conhecimento".

Essa concepção de uma literatura que estivesse a serviço do homem, Sartre vai buscála no Iluminismo francês e vai contrapô-la à literatura alienada, quase desprovida de conteúdo político-social e só preocupada com o fato estético, surgida na França, por volta de 1850, através da autonomização do campo literário, e ainda sobrevivente em 1947, ano em que escreveu e publicou Que é a literatura?, obra essencial para quem quer compreender o engajamento literário.

Ora, sabemos que toda obra literária, conforme a assertiva de Antonio Candido (2000), não está isenta de modo algum de conter elementos sociais em sua estrutura interna, muito pelo contrário, visto por esse viés, ela é uma representação de uma dada realidade social e humana, por mais que se queira transparecer descompromissada socialmente. Exemplo disso, são os romances de Gustave Flaubert e os poemas de Charles Baudelaire, representantes ilustres do período de autonomização do campo literário francês, que, embora privilegiassem a estrutura literária, não conseguiram se esquivar de representar a realidade social da época. Desse modo, o que os idealizadores e simpatizantes da autonomização do campo literário pretendiam era uma desvinculação completa entre a literatura e o elemento político que a sociedade carrega em si.

Em busca de uma nova articulação entre o literário e o social, que envolvesse o aspecto político, Sartre vai contrapor-se totalmente a esse tipo de literatura, da arte pela arte, que se quer descompromissada politicamente, pois, lembrando a assertiva de Fredric Jameson (1992, p. 18), "tudo é, em última análise, político", e vai conceber o engajamento literário como uma "tomada de posição refletida, consciência lúcida do escritor de pertencer ao mundo e vontade de mudá-lo" (DENIS, 2002, p. 37-38). Assim, o "engajar-se", verbo que entre outras coisas significa "pôr-se a serviço de uma causa", adquire para ele o sentido de "tomar 
partido" através da literatura, pois, concebendo-a, assim como Alejo Carpentier, como um meio de ação, ela é por essência uma tomada de posição.

Nesse sentido, após fazer uma reflexão sobre a condição de mediador do escritor, dividido entre duas classes sociais, a burguesia, da qual é originário, e o proletariado, ao qual é solidário; ao chamado do momento histórico, que incita à ação; e à natureza libertadora da literatura, que lhe permite expressar a totalidade da condição humana, não deixando de mencionar as conveniências da neutralidade, Sartre não hesita em afirmar:

\begin{abstract}
A cada dia é preciso tomar partido, em nossa vida de escritor, em nossos artigos, em nossos livros. Que isso se faça sempre conservando como princípio diretor dos direitos da liberdade total, como síntese efetiva das liberdades formais e materiais. Que essa liberdade se manifeste em nossos romances, nossos ensaios, nossas peças de teatro. E como nossas personagens ainda não podem usufruí-la, pois são homens do nosso tempo, saibamos ao menos mostrar o que lhes custa a sua falta. Não basta mais denunciar, com belo estilo, os abusos e as injustiças, nem descrever com brilhantismo e negatividade a psicologia da classe burguesa, nem mesmo colocar nossa pena a serviço dos partidos sociais: para salvar a literatura é preciso tomar posição na nossa literatura, pois a literatura é por essência tomada de posição. (SARTRE, 2006, p. 204)
\end{abstract}

Dessa forma, ele defende a ideia de uma arte literária imbuída de um socialismo que não seja um fim absoluto, mas o fim do começo ou o meio antes do fim, com o objetivo de "colocar a pessoa humana em posse de sua liberdade" (Ibid.). Ou seja, que o socialismo fosse o veículo condutor da literatura para que esta pudesse contribuir para a libertação política do homem.

A tomada de posição que deve ser feita pelo escritor, no entender de Jean-Paul Sartre, é "tomar partido contra as injustiças, de onde quer que venham" (Ibid., p. 209). Isso implica a existência de liberdade de pensamento e expressão para o escritor e coragem da parte dele para que possa conceber uma literatura livre de quaisquer compromissos com governos ou partidos políticos e compromissada apenas com a liberdade e o bem-estar do ser humano. Desse modo, num mundo pós-segunda guerra mundial e início de guerra fria, o escritor 
precisava denunciar "tanto a política da Inglaterra na Palestina e dos Estados Unidos na Grécia, como as deportações soviéticas" (Ibid.), ou seja, tanto as arbitrariedades cometidas pela política capitalista e imperialista inglesa e americana, quanto àquelas praticadas pelo regime comunista soviético, que na época já começava adquirir também ares imperialistas, deveriam ser denunciadas pelo escritor em seus textos, pois é a sua tarefa "representar o mundo e testemunhar sobe ele" (Ibid., p. 210), tomando "a liberdade como princípio e fim de toda atividade humana"(Ibid.), para que possa contribuir para por um fim no "regime de exploração do homem pelo homem" (Ibid.).

Como o escritor é um intelectual "por essência", pelo fato de ele apresentar a condição humana tomada em seu nível radical, o ser no mundo, sob a forma de um objeto artístico, a obra literária, (SARTRE, 1994, p. 64), essa postura exigida do escritor por parte de Jean-Paul Sartre transforma-o num outsider (fora do lugar), termo cunhado por Edward Said (2005) para definir o lugar na sociedade a ser ocupado pelo intelectual. Dessa forma, o escritor, enquanto intelectual, ocupa um lugar à margem dentro da sociedade, um lugar único, que não é de centro, nem de direita ou de esquerda, por causa de seu compromisso humanitário de denunciar todas as injustiças e arbitrariedades cometidas por homens ou por regimes políticos contra o ser humano. Para Said (Ibid.), o intelectual é um perturbador do status quo, não é nem um pacificador nem um criador de consenso, mas "alguém que empenha todo o seu ser no senso crítico, na recusa em aceitar fórmulas fáceis ou clichês prontos, ou conformações afáveis, sempre tão conciliadoras sobre o que os poderosos ou convencionais têm a dizer e sobre o que fazem." (SAID, 2005, p.35-36). Vale lembrar que nem todos os intelectuais tiveram uma conduta ética coerente e compromissada com a liberdade humana como pensavam Sartre e Said. Exemplo são os casos dos poetas Ezra Pound e Marinetti e do filósofo Martin Heidegger. Os dois primeiros aliados do fascismo italiano e o último, adepto do nazismo alemão. 
Quanto à função social do intelectual, Said acredita que as suas tarefas residem no esforço em derrubar os estereótipos e as categorias redutoras que tanto limitam o pensamento humano; em promover a liberdade humana e o conhecimento; em buscar uma relativa independência em face das pressões a que está sujeito, pois a liberdade de opinião e de expressão é o principal bastião do intelectual; e também encontrar espaço para enfrentar e retrucar a autoridade e o poder, porque, segundo ele, a subserviência inquestionável à autoridade é uma das maiores ameaças a uma vida intelectual ativa, baseada em princípios de justiça e equidade. Nesse sentido, o engajamento literário do escritor transforma-o num intelectual em ação, cumprindo com a sua função social através da denúncia de todo tipo de violência e injustiça que possa por em risco a liberdade humana.

Aqui é pertinente lembrar definição de engajamento feita por Simone de Beauvoir, considerada por Benoît Denis a melhor definição do termo por ser mais fácil de ser compreendida, pelo fato de ela vir ao encontro do pensamento de Edward Said sobre a condição e a função do intelectual. Para Beauvoir (1963, p. 65), o engajamento é "a presença total do escritor na literatura". Segundo Denis (2002, p.46), esse conceito de engajamento em que o escritor "coloca o conjunto dos valores nos quais acredita e pelos quais se define", faz com que ele coloque em jogo muito mais do que a sua reputação literária, arriscando-se integralmente no processo de escrita ao inserir no texto literário "a sua visão de mundo e as escolhas que dirigem a sua ação." Visto a problemática do engajamento literário por esse ângulo, conclui o autor, coloca-se então no centro dela a questão da responsabilidade do escritor:

Se engajar-se consiste assim em colocar a sua pessoa na linha de frente da obra literária, isso significa também que o escritor assume a hipótese de que ele possa ser julgado a partir das suas obras. A autonomia de que goza a literatura não pode preservá-lo da sanção moral ou social; ele será abjeto ou magnífico, covarde ou corajoso, dependendo da aprovação ou repulsa que obtenha dos fatos e dos homens. Engajar-se consiste, portanto, para o escritor, em aceitar sofrer esse tipo de processo, sem que o álibi da liberdade de criação ou da incomensurabilidade da exigência literária com relação à 
moral comum ou social o proteja do julgamento que a coletividade poderá fazer sobre a qualidade do seu engajamento. (DENIS, 2002, p. 46)

Desse modo, o engajamento literário implica uma grande responsabilidade por parte do escritor sobre aquilo que ele produz e oferece à sociedade, e uma escolha consciente dos riscos que ele poderá correr, conforme for a repercussão de sua obra. A berlinda em que essa atividade intelectual coloca o escritor lembra-nos a observação feita por Edward Said (2005, p.22) sobre a atitude que os intelectuais devem ter, conforme a definição de Julien Benda, que postulava que "os verdadeiros intelectuais devem correr o risco de ser queimados na fogueira, crucificados ou condenados ao ostracismo". Nesse aspecto não podemos esquecer as inúmeras obras literárias que foram condenadas e queimadas em praça pública por regimes autoritários, inclusive com o exílio ou a prisão de muitos escritores, cujo exemplo mais recente talvez seja o do romancista Salman Rushdie, condenado pelo líder religioso Aitolá Khomeini por causa de seu romance Versículos satânicos. E embora não seja exatamente um texto literário, é o caso de lembrar também as consequências do famoso artigo Eu acuso, de Émile Zola, no qual o escritor protesta contra a prisão do capitão Alfred Dreyfus, um texto que é uma espécie de certidão de nascimento do intelectual e que rendeu ao romancista francês perseguição política, condenação, exílio e uma morte em circunstâncias suspeitas.

Essa postura de guardião da liberdade e do bem-estar humanos torna também o escritor um "homem-contradição", termo que sintetiza a definição do intelectual feita por Jean-Paul Sartre (1994). Sartre define o intelectual moderno dessa forma porque, primeiro sendo humanista desde a infância, ele acreditou que todos os homens fossem iguais, e quando toma consciência de ser um sujeito detentor de um saber conquistado por herança (filho de alto funcionário assalariado ou profissional liberal) ou através de um sistema de seleção complexo e injusto, se for filho de operário, que eliminou a grande maioria de seus companheiros, vê em si mesmo a prova da desigualdade das condições humanas. Assim, para Sartre, esse privilégio injusto está em total contradição com o seu caráter humanista, e para 
renunciar a esse privilégio teria que se anular, solução que contradiz o instinto de vida profundamente enraizado tanto no intelectual quanto na maioria dos homens.

Assim, ainda de acordo com Sartre (Ibid, p.30-31), o intelectual é o homem que se conscientiza da oposição que há, em si mesmo e na sociedade, entre a verdade prática e a ideologia dominante, e essa conscientização põe a descoberto as contradições fundamentais da sociedade, ou seja, os conflitos de classe no seio da classe dominante: um conflito orgânico entre a verdade que ela reivindica para seu empreendimento e os mitos, valores e tradições que ela mantém e que quer transmitir às outras classes para garantir sua hegemonia. Sob esse aspecto, Sartre (1994, p. 64) afirma que a obra literária deve ter por objetivo testemunhar e explorar "o paradoxo que é o homem no mundo"

Dessa forma, o escritor, um intelectual por essência no entender de Sartre, deve guiarse por uma conduta ética inquestionável e essa postura crítica exigida dele transforma-o num indivíduo que ocupa um lugar único dentro da sociedade (um outsider), alguém que consegue enxergar as hipocrisias e as contradições existentes no seio dessa sociedade e por isso deve denunciá-las através de seus escritos; e, ao mesmo tempo, ele é também um "homemcontradição", devido à sua condição humana, imperfeita e comum a todos os homens; e pelo fato de que muitos dos problemas sociais e injustiças identificados por ele o afetam diretamente, muitas vezes, tendo-o como beneficiário. Isso faz com que as suas críticas, às vezes, voltem-se contra ele mesmo e o façam até parecer hipócrita diante de seus críticos e leitores.

Nesse sentido, então, a obra literária do escritor/intelectual deve ser engajada, ou melhor, deve ser compromissada com os problemas político-sociais de seu tempo, pois conforme nos aponta Edvaldo Bergamo (2008, p. 47), para o escritor engajado "não basta a realização estética, seu projeto literário requer um comprometimento humanitário, que 
justifique a sua escolha ideológica", realizada em benefício da coletividade. Nesse sentido, Benoît Denis afirma:

O escritor engajado não acredita que a obra literária remeta apenas a ela mesma e que encontre nesta auto-suficiência a sua justificação última. Ao contrário, ele a pensa atravessada por um projeto de natureza ética, que comporta uma certa visão do homem e do mundo, e ele concebe, a partir disso, a literatura como uma iniciativa que se anuncia e se define pelos fins que persegue no mundo. Para dizer de outro modo, o escritor engajado é aquele que pede à literatura para dar as suas razões, e que sustenta que essas razões não podem se encontrar numa essência de literatura definida a priori, mas na função que a literatura entende preencher na sociedade ou no mundo. Para ele, escrever volta a supor um ato público no qual ele empenha toda a sua responsabilidade. (DENIS, 2002, p.35)

Isso equivale a uma recusa da concepção da obra literária como algo apenas gratuito, sem finalidade, encerrada em si mesma. Sob esse aspecto, o projeto literário de um escritor engajado comporta também um projeto ético, fiel à sua visão de mundo e ao seu compromisso social e humano, de modo que seus escritos tenham, no âmbito geral, uma função na sociedade na qual circulam, que pode ser entendida, num plano específico, em várias funções como a formativa, humanizadora e ideológica, que possam, conforme o pensamento de JeanPaul Sartre (2006), desvendar o homem e o mundo para os outros homens, a fim de que eles possam conhecê-los e assumir suas responsabilidades perante eles.

Desse modo, ainda segundo Sartre, o ato criador de uma obra literária objetiva realizar uma retomada total do mundo, é uma recuperação da totalidade do ser, que é apresentada ao leitor para que ele possa recuperá-lo através da leitura, pois "é bem esta a finalidade da arte: recuperar o mundo, mostrando-o tal como ele é"(SARTRE, ibid., p. 47), e por vezes esse mostrar o mundo pode revelar à sociedade uma imagem não desejada, ou seja, pode dar a ela "uma consciência infeliz" (SARTRE, 2006, P. 65).

Para tanto, e principalmente para não correr o risco de descambar para o gênero panfletário, o escritor deve saber dosar "a combinação adequada entre utilidade e gratuidade" (CANDIDO, 1999, p. 105), ou seja, entre a ficção e a realidade, o literário e o político-social, 
pois conforme nos afirma Benoît Denis (2002, p. 12-13), "o engajamento implica com efeito numa reflexão do escritor sobre as relações que trava a literatura com a política (e com a sociedade em geral) e sobre os meios específicos dos quais ela dispõe para inscrever o político na sua obra."

A partir dessa afirmação, podemos pensar nos meios específicos de que a literatura dispõe para abarcar o político-social como elemento externo à sua estrutura e transformá-lo em elemento interno, com um papel significativo na configuração da obra literária (CANDIDO, 2000), de modo que ela seja permeada por um inconsciente político, conforme pensa Fredric Jameson (1992). Primeiramente, vejamos o pensamento de Benjamin Abdala Júnior sobre a questão:

O engajamento literário leva o escritor à explicitação, criando formas do imaginário de ênfase política. Para ele, a literatura discute questões fundamentais do ser e da vida político-social e procura desenvolver estratégias discursivas tendo em vista romper com a alienação do cotidiano que, na sociedade massificante, leva à minimização da própria significação. (ABDALA JÚNIOR, 2007, p. 271-272)

Diante disso, na obra literária engajada, temos um conteúdo político-social que é levado ao público-leitor através da mediação de estratégias discursivas, que por sua vez dão o tom literário a ela, impedindo-a de que seja confundida com propaganda política partidária. Assim, o engajamento literário se realiza por meio da confluência entre "conceitos próprios da arte e conceitos próprios da ética e da política" (BOSI, 2002, p. 119), ou seja, através da conciliação da ética com a estética, pois o ato de engajar-se literariamente implica numa escolha ética( a temática a ser abordada), acompanhada de uma escolha estética(as estratégias narrativas de que o escritor lançará mão para conceber a sua obra). Nesse sentido, Alfredo Bosi (2002), partindo do princípio que a escrita de uma obra literária de resistência, nomenclatura pela qual denomina a literatura engajada, decorre de um princípio ético, afirma que o romancista engajado 
dispõe de um espaço amplo de liberdade inventiva. A escrita trabalha não só com a memória das coisas realmente acontecidas, mas com todo o reino possível do imaginário. $\mathrm{O}$ narrador cria, segundo o seu desejo, representações ambivalentes. Graças à exploração das técnicas do foco narrativo, o romancista poderá levar ao primeiro plano do texto ficcional toda uma fenomelogia de resistência do eu aos valores ou antivalores do fenômeno ético de resistência, o que é a figura moderna do herói antigo. Esse tratamento livre e diferenciado permite que o leitor acompanhe os movimentos não raro contraditórios da consciência, quer das personagens, quer do narrador em primeira pessoa. (BOSI, 2002, p. 121-122)

Dessa forma, as técnicas narrativas constituem-se na principal ferramenta de que o escritor dispõe para aliar o seu projeto ético a um projeto estético. Como exemplo, Bosi cita a polifonia existente em Os irmãos Karamazovi, de Dostoievski, que, a seu ver, "ilustra bem a relação entre instâncias éticas e formas de construção da narrativa", pelo fato de que "as vozes das personagens são pontos de vista que trazem à superfície da escrita o núcleo moral onipresente em Dostoievski" (Ibid., p. 122).

Além da polifonia, podemos citar também a técnica do contraponto, que é uma espécie de desenvolvimento da polifonia, a técnica de narração cinematográfica incorporada à literatura, a metaficção, as diversas formas de se trabalhar com o tempo e o espaço narrativos, a alegoria, e também a escolha de determinados temas.

\subsection{Literatura de engajamento, literatura militante e literatura engajada}

Embora, aparentemente, o conceito de literatura engajada pareça claro por designar "uma prática literária estreitamente associada à política, aos debates gerados por ela e aos combates que ela implica” (DENIS, 2002, p. 9), ele ainda causa alguma controvérsia quando se pensa em sua definição, pelo fato de haver certa confusão entre o texto engajado e o militante. A esse respeito Benôit Denis faz a seguinte distinção entre ambos: 
Contrariamente a uma opinião difundida, a literatura engajada não é antes de tudo política; ela só o é em virtude de uma necessidade secundária, que quer que as questões morais ou éticas, colocadas concretamente e coletivamente desemboquem quase inevitavelmente em considerações políticas (....). É isso que distingue a literatura engajada da literatura militante: a primeira vem à política porque é nesse terreno que visão do homem e do mundo da qual ela é portadora se concretiza, enquanto que a segunda já é desde o início política. Também o escritor engajado é, por fim, raramente filiado a um partido e se sente muito pouco como porta-voz de uma doutrina política; os seus textos, antes, manifestam as contradições e as dificuldades de uma empreitada onde a política, avaliada pelo lado da moral, aparece, frequentemente, mais como um mal necessário do que uma escolha positiva. (DENIS, 2002, p. 36)

Por essa distinção entendemos que a literatura engajada é, antes de tudo, literatura, ou seja, ela é primeiramente ficção, um objeto estético, que internaliza o fator político-social, transformando-o num elemento importante em sua estrutura, conforme assertiva de Antonio Candido (2000) sobre os fatores externos que condicionam a obra literária, porque é o campo da política que possibilita a ela realizar uma retomada total do mundo, conforme pensa JeanPaul Sartre (2006), pois segundo ele, é tarefa do escritor "fazer entrever os valores de eternidade que estão implicados nos debates sociais e políticos", de forma que ela é uma literatura que é portadora de um discurso político, sem, no entanto, que o elemento político predomine sobre o literário. Em contrapartida, a literatura militante é o texto de cunho político que se utiliza das convenções literárias para se constituir como literatura, ou seja, ao contrário da literatura engajada, ela é primeiramente política para depois se tornar literatura.

Realizada essa distinção, resta ainda outro problema em relação à literatura engajada, no que concerne à sua delimitação, em razão de que muitos críticos literários defendem a ideia de que toda obra literária possui um grau mínimo de engajamento por apresentar uma forma particular de ver o mundo, inclusive Sartre, para quem todos os escritores eram, de uma forma ou de outra, "comprometidos", o que equivale a dizer que "toda obra literária, qualquer que seja a sua natureza e a sua qualidade, é engajada, no sentido de que ela é portadora de 
uma visão de mundo situada e onde, queira ela ou não, se revela assim impregnada de posição e escolha", conforme a interpretação do texto sartriano feita por Benoît Denis (2002, p. 36).

Nesse sentido, Denis observa que por conta dessa ampla e flexível noção de engajamento, ele sofreu um considerável desgaste no decorrer dos anos, tornando-se uma ideia fluida e de uso generalizado, de forma que toda obra literária seria em algum grau engajada pelo fato de expressar uma visão de mundo e de dar forma ao real. A esse respeito, o autor lembra que sempre existiu uma literatura de combate, preocupada em tomar parte nas controvérsias políticas ou religiosas de seu tempo, desde o teatro de Aristófanes, na Grécia antiga, passando por Cícero, na Roma imperial, Pascal e Montesquieu, na França iluminista. Como exemplos brasileiros, podemos juntar a esses nomes os poetas Tomás Antônio Gonzaga e Castro Alves, que através de seus poemas "Cartas chilenas", e "Navio negreiro" também discutiram questões políticas relevantes da época em que viveram.

Contudo, Denis observa que pouca ou nenhuma relação há entre esses autores que produziram uma literatura de combate num passado mais distante, ou seja, não há um liame que possa ligá-los, um elemento comum entre eles que possa relacioná-los, como uma ideologia, por exemplo, diferentemente dos escritores engajados que produziram suas obras na primeira metade do século XX, nos quais é possível perceber estreitas relações entre eles e um diálogo constante no campo literário, pois havia a solidariedade humana e a luta contra o nazismo e o fascismo que os unia.

Diante disso, ele vê duas possibilidades para a conceituação da literatura engajada: a primeira, como um fenômeno historicamente situado, geralmente associado a Jean-Paul Sartre, que foi o seu principal teorizador e defensor, e à emergência no pós-guerra de uma literatura preocupada com as questões políticas e sociais e também desejosa de mudar o mundo, a partir do modelo ideológico da Revolução russa de 1917; e a segunda, tendo uma noção de engajamento bem mais ampla e flexível, que acolheria em seu bojo, além dos 
escritores já citados anteriormente, uma série de outros como Voltaire, Vitor Hugo, Émile Zola e Péguy, autores que se preocuparam com a vida e organização social e fizeram em seus escritos a defesa de valores universais, como a liberdade e justiça, sendo que por causa dessa atitude sempre correram o risco de se chocarem com os poderes constituídos. Por essas duas perspectivas, ele conclui que:

A literatura engajada pode, portanto, ser apreciada a partir de dois pontos de
vista: seja ela considerada como um "momento" da história da literatura
francesa, quer dizer, como uma corrente ou uma doutrina que conheceu o
seu apogeu mais intenso entre 1945 e 1955 , antes de ceder lugar a outras
concepções ou práticas da escritura literária, que lhe foram ao menos
parcialmente opostos (o novo romance, o pensamento estruturalista, a Nova
Crítica etc.); seja o engajamento na literatura como uma possibilidade
literária transhistórica, que se encontra sob outros nomes e com outras
formas ao longo de toda história da literatura. (DENIS, 2002, p. 18)

Diante das duas acepções possíveis, Benôit Denis resolve o impasse utilizando a expressão "literatura de engajamento" para denominar "esse vasto conjunto transhistórico da literatura de alcance político" (Ibid. p. 12) que sempre existiu e que, como vimos, retrocede até às antigas literaturas da Grécia e Roma, e reservando a expressão "literatura engajada" à literatura de combate produzida no século $\mathrm{XX}$, tomando como ponto de partida o caso Dreyfus e ponto de chegada o final desse mesmo século, pelo fato de que "é com efeito durante esse período que essa problemática desenvolveu-se e foi formulada com precisão, que ela tomou essa denominação e que se se tornou num dos eixos maiores do debate literário.” (DENIS, 2002, p. 11). Assim, ele opta por delimitar o termo "literatura engajada" a um período histórico em que havia elementos comuns entre os escritores considerados engajados, laços criados pelo próprio contexto histórico-político-social em que viviam e também porque foi nesse período que ela foi teorizada e se transformou num dos dois grandes polos da discussão literária: "arte ou vida, beleza ou verdade, contemplação ou participação", conforme afirma Antonio Candido (1972b, p. 43) ao analisar os dilemas vividos pelos 
escritores brasileiros da década de 30 . É somente a partir desse período que se pode entender o sentido de engajamento e aplicá-lo a outras épocas da história literária:

É preciso (...) partir da literatura engajada tal como ela se apresentou no século XX: o engajamento sendo discutido e se definindo ao longo desse século, adquiriu um valor trans-histórico e tornou-se numa possibilidade literária suscetível de se aplicar a outros momentos ou outras épocas da história literária. É, portanto, a partir do modo como ele foi pensado por Sartre e os seus contemporâneos, que pode-se tentar retornar no tempo e examinar de que maneira escritores ou homens de letras quiseram desenvolver uma concepção e uma prática "engajada" de escritura, num tempo em que a noção de engajamento não existia como tal.

Ter-se-á, portanto, definido: para nós, a literatura engajada pareceu antes de tudo historicamente situada. (DENIS, 2002, p. 19)

Desse modo, a literatura engajada, tal como nós a conhecemos hoje, é um fenômeno do século $\mathrm{XX}$, embora o sentido de engajamento esteja presente na literatura desde a antiguidade. Ela se desenvolveu no período histórico mais conturbado que a humanidade já teve na era moderna, o chamado período entreguerras que, além das duas grandes guerras mundiais lhe servindo de moldura, também abrigou em seu bojo a Revolução Russa de 1917, a qual, embasada na teoria de Karl Marx, apresentou um novo modelo de sociedade para mundo, o que, por sua vez, trouxe entusiasmadas adesões como também vigorosos repúdios. Também não podemos esquecer que nesse período, além do comunismo soviético, houve a emergência de regimes autoritários de extrema direita, o fascismo italiano e espanhol e o nazismo alemão, que foram os responsáveis diretos pela Guerra Civil Espanhola e a Segunda Guerra Mundial. Todos esses elementos históricos, políticos e sociais serviram de matériaprima para o desenvolvimento da literatura engajada.

Dessa forma, o aparecimento de ideologias e regimes políticos antagônicos transformou a Europa num campo marcado pelas discussões ideológicas que, por vezes, levaram as principais nações europeias ao conflito armado, vitimando dezenas de milhões de pessoas, seja através da violência direta da guerra ou pela fome e a doença causadas por ela. Diante de tal cenário desolador, surge uma literatura comprometida com o ser humano, 
denunciando a violência, a fome e a injustiça disseminadas tanto por regimes políticos autoritários quanto por regimes capitalistas democráticos.

Essa literatura de combate e resistência a todos os tipos de violência cometidos contra o ser humano, escrita no decorrer do século XX, é o que se denominou de literatura engajada, cujo desenvolvimento pode ser dividido em três fases:

A primeira, anunciada desde o caso Dreyfus, cobre o entre-guerras e pode ser considerada como um período de debates e de acertos durante o qual se definiu a problemática da literatura engajada; a segunda, ligada à hegemonia sartreana, representando o momento "dogmático" do engajamento dura uma quinzena de anos a partir do fim da Segunda Guerra Mundial; e na metade dos anos 50 se inaugura com Roland Barthes uma terceira fase, que se poderia qualificar de "refluxo", durante a qual a concepção sartreana de engajamento se verá contestada em proveito de uma outra definição de relação entre o literário e o social. (DENIS, 2002, p. 26)

Considerando que a questão do engajamento se constituiu no eixo estruturante mais importante do debate literário do século XX, Benôit Denis acredita que o surgimento da literatura engajada, nos moldes configurados no decorrer desse século, foi determinado pela conjunção de três fatores: o aparecimento de um campo literário autônomo por volta de 1850; a invenção do intelectual, a partir do caso Dreyfus; e a Revolução russa de 1917.

O primeiro fator, o campo literário autônomo, segundo ele, se constituiu num campo literário independente da sociedade e das suas instâncias de poder, tanto no seu princípio quanto no seu funcionamento, de modo que os escritores não se submetiam mais a elas e somente à jurisdição de seus pares. Uma das consequências dessa autonomização da atividade literária foi o estabelecimento de um corte profundo entre literatura e sociedade, pelo fato de os escritores de então terem adotado várias medidas com o intuito de distingui-los do homem comum, ao mesmo tempo em que elaboraram novas regras do jogo literário, visando ao reconhecimento da especificidade de suas atividades. Desse modo, eles concentraram as suas atenções no trabalho da forma literária e tomaram distância dos problemas políticos e sociais, pois se recusavam a ter qualquer dívida com a sociedade e tomar parte nos debates e nas lutas 
que a agitavam. $\mathrm{O}$ aparecimento da literatura engajada foi, então, uma reação a essa autonomização literária que excluía o conteúdo político de seu projeto artístico.

O segundo fator importante para o aparecimento da literatura engajada foi a invenção do intelectual, essa figura polêmica por essência surgida na França no final do século XIX, por ocasião do "caso Dreyfus". Na época, o capitão das forças armadas francesas Alfred Dreyfus, de origem judia, foi acusado injustamente de traição por atos de espionagem em favor da Alemanha. A condenação injusta por alta traição desencadeou uma série de protestos envolvendo pessoas com diferentes tendências políticas e culminou na absolvição completa de Dreyfus em 1906. A maior dessas manifestações foi o artigo Eu acuso, do escritor Émile Zola.

Tomando o caso Dreyfus como ponto de partida do aparecimento do intelectual, JeanPaul Sartre (1994) afirma que o termo "intelectual” surge com uma conotação pejorativa para designar alguém que se mete no que não é da sua conta, ou seja, alguém que, atingindo uma notoriedade em algum campo do saber, como a literatura, a filosofia e a ciência, abusava desse mérito adquirido, saindo de seu domínio e entrando em outros, como o político, por exemplo, e assim criticava sociedade e os poderes estabelecidos em nome de uma concepção global e dogmática do homem, que, segundo ele, pode ser vaga ou precisa, moralista ou marxista.

A partir da entrada em cena desse novo personagem social, a literatura vê o seu prestígio reforçado pelo fato de que "o escritor que procede como intelectual permanece um escritor e é esse prestígio que ele coloca em jogo na sua intervenção" (Id. Ibid.).

O terceiro fator a colaborar para o surgimento da literatura engajada, a Revolução Russa de 1917, na visão de Benôit Denis, foi decisiva pelo fato de se tratar de um evento dominante e fundador, que seduziu a camada literária e intelectual do período entreguerras. Entre os motivos para esse forte poder de atração exercido pela Revolução de outubro, elenca 
o apego francês à ideia de revolução, de modo que para muitos franceses a Revolução Russa representou a conclusão de um processo histórico iniciado pela Revolução Francesa, em 1789; e a carnificina Primeira Guerra Mundial (1914-1918), que deixou a Europa arrasada e sem perspectiva. Dessa forma, o evento russo tornou-se uma luz utópica para a intelectualidade de um continente destroçado e sem esperança. Assim, "a revolução é portadora de uma nova universalidade, utópica ela também, da qual o escritor quer, porém, assenhorar-se: aquela da sociedade sem classes, na qual será preciso que ele encontre o seu lugar e seu papel” (Id., ibid.).

Para Denis, o efeito mais visível da influência da Revolução Russa se nota nas décadas de 20 e 30, quando há uma grande politização do campo literário, não apenas na Europa, mas também na América, como veremos mais tarde, que se divide entre direita e esquerda e entre escritores engajados e não engajados. Também, não menos importante é a renegociação das relações entre o político e o literário que ocorre nesse mesmo período, de modo que as regras do jogo literário estabelecidas no século passado pela autonomização do campo começam a ser modificadas, colocando em xeque a autonomia do campo literário.

Desse modo, a conjunção desses três fatores, a autonomização do campo literário, o surgimento do intelectual e a Revolução Russa, criou as condições para que surgisse a literatura engajada, conforme ela foi teorizada por Jean-Paul Sartre e praticada por escritores europeus, norte-americanos, latino-americanos e africanos durante o decorrer do século XX, que fizeram do engajamento uma das linhas mestras dos seus projetos literários.

Aqui é importante lembrar o ponto de vista de Alfredo Bosi (2002, p. 120) sobre a "narrativa de resistência", expressão pela qual o crítico brasileiro denomina a literatura engajada, pelo fato de que ele se aproxima muito do conceito formulado por Benoît Denis. Para Bosi, a obra literária resistente, no que concerne à narrativa, tem sido realizada de duas 
maneiras que, necessariamente, não se excluem: a resistência como tema e a resistência como processo de escrita.

Na primeira delas, ele pensa a narrativa de resistência como uma cultura de resistência política que predominou, principalmente, entre os anos 30 e 50 do século XX, quando inúmeros escritores se engajaram, tanto literariamente quanto literalmente, na luta contra os regimes de opressão que punham em risco a liberdade humana, onde "as ações de cada escritor, por diferenciadas que fossem, destacavam-se todas de um mesmo fundo axiológico, que se pode qualificar de mentalidade antiburguesa gerada dialeticamente como um não lançado à ideologia dominante." (Ibid., p. 129). Nesse aspecto, a resistência literária pensada como tema, corresponde ao modelo de literatura engajada teorizada e defendida por Jean-Paul Sartre.

Quanto à resistência como processo de escrita, para Bosi ela ocorre em obras literárias escritas independentemente de qualquer cultura de resistência política, nas quais há uma tensão interna que as faz resistentes enquanto escrita e não só como tema. Sob essa perspectiva, $O$ ateneu, de Raul Pompéia, os romances de Thomas Mann, Marcel Proust e Clarice Lispector seriam resistentes no seu processo de escrita, do ponto de vista ou da estilização da linguagem. Essa acepção de literatura de resistência, que privilegia a forma literária, vai ao encontro do conceito de engajamento literário pensado por Roland Barthes que, segundo Benoît Denis (2002), a partir de O grau zero da escrita (2004) começa a contestar a concepção sartriana que colocava a forma a serviço do conteúdo, e também da ideia do engajamento como um processo transhistórico, pensada por Denis.

Como eixo norteador de nossa pesquisa, adotaremos o conceito de "literatura engajada", concebido por Benoît Denis a partir da teorização do engajamento literário realizada por Jean-Paul Sartre, que encontra correspondência no conceito de "narrativa de resistência como tema", formulado por Alfredo Bosi, sem, no entanto, descurar-nos da ideia 
de uma narrativa resistente como processo de escrita, pois, lembrando Bosi (2002), elas não se excluem necessariamente e, em muitos casos, entendemos que elas se complementam.

\subsection{O romance engajado do século $X X$}

Desse modo, conforme vimos anteriormente, a literatura engajada, nos moldes como foi difundida no século XX, é um fenômeno especificamente moderno, embora a ideia de engajamento seja tão antiga quanto a própria literatura e, da maneira como ela foi teorizada por Jean-Paul Sartre e elaborada por ele e seus contemporâneos, ela se dá principalmente como tema que aborda as crises sociais, políticas e históricas que afetaram a vida da humanidade no século passado e que também deram origem a ela, tomando quase sempre o excluído como objeto de sua escrita, pois ela é acima de tudo uma literatura que possui um comprometimento humanitário e, por essa razão, considera seu dever denunciar toda espécie de violência cometida contra o ser humano.

Antes de mais nada, é preciso lembrar que embora exista um teatro engajado e uma poesia engajada, ainda que esta seja negada por Sartre, é no romance que a literatura engajada encontrou território fértil para se desenvolver. Uma das principais causas dessa predisposição para o engajamento foi a incorporação do "realismo formal" feita pelo romance no século XIX. O realismo formal é o termo cunhado por Ian Watt (1990) para designar um modo de composição narrativa em que a realidade e suas implicações históricas, políticas e sociais são reelaboradas artisticamente. Edvaldo Bergamo (2008), tomando por base o pensamento de Ian Watt, afirma que o realismo formal, ou método realista conforme ele próprio prefere denominar, tornou-se um valioso instrumento de análise histórica da sociedade e, assim, propiciou o desenvolvimento do romance, tornando-o um veículo de expressão da realidade e 
um relato verossímil da experiência social e individual no período da consolidação da burguesia.

Conforme nos aponta Benoît Denis (2002, p. 87-88), a estética realista, que se conduz por essa forma de composição narrativa, possui uma vocação totalizante que dá "o suporte ideal de uma representação engajada do real e da História". Desse modo, o romance realista representa o real, reconstruindo-o, organizando-o e interpretando-o, num processo denominado de "mediação" por Raymond Willians (1979), através do qual o real, o conteúdo histórico-político-social é formulado artisticamente, transformando-se num objeto estético. Sob esse aspecto, num sentido bem mais amplo, há sempre "um engajamento do romancista, já que a sua narrativa é sempre orientada por uma visão de mundo situada e singular, a qual determina tanto os assuntos abordados quanto as técnicas narrativas utilizadas" (DENIS, 2002, p. 88). No entanto, além disso, observa o autor francês, é necessária, também, uma tomada de posição refletida, lúcida e voluntária por parte do romancista, acompanhada da recusa de todo tipo de imparcialidade ou passividade em relação ao real representado para que se possa engajar o romance no sentido pleno do termo.

Como sabemos, o romance realista teve seu desenvolvimento no século XIX, através, principalmente, das figuras dos romancistas Charles Dickens, Stendhal, Balzac, Flaubert, Tolstoi e Dostoievski, mas adentrou o século seguinte como um instrumento adequado para realizar o desvendamento do mundo para leitor, através da denúncia da alienação humana, da exploração capitalista e de todas as injustiças e violências cometidas contra o homem, conforme observa Edvaldo Bergamo:

O método realista ou "realismo formal" desempenhou, durante todo o século XIX, um crescente papel crítico que se manifestou privilegiadamente na forma romanesca, para desvelar as mazelas da sociedade oitocentista. Já em pleno século XX, o romance torna-se um instrumento ainda mais preparado ideologicamente para denunciar as diversas formas de alienação, decorrentes do modo capitalista de vida, apostando numa captação realista da experiência social em um mundo contraditório, mesmo quando a opção é pelo fantástico. (BERGAMO, 2008, p.39) 
Essa tendência realista do romance que se forma a partir de então, ainda segundo Bergamo, não se esgota diante das transformações pelas quais o gênero passa; pelo contrário, ela parece se fortalecer ainda mais e como exemplo o autor cita o romance social dos anos 30 e 40 do século XIX, também denominado em muitos países de Neorealismo, que foi o principal gênero na difusão da literatura engajada.

Dessa forma, o romance engajado do século XX é um herdeiro direto da tradição realista, pelo fato de, a exemplo do seu antecessor, ser "portador de uma veemente ação crítica contra o meio social, ao expor aquilo que está escondido sob as malhas de uma conjuntura histórica opressora e reificadora" (BERGAMO, 2008, p. 44), ou seja, ele apresenta à sociedade uma imagem infeliz dela mesma, conforme o pensamento de Sartre (2006). O que os diferencia é que os eventos ocorridos no decorrer do século $\mathrm{XX}$, principalmente a Revolução Russa, as duas grandes guerras mundiais e Guerra civil espanhola, e o surgimento de regimes autoritários no período do entreguerras, fazem com que o romancista, exprimido entre ideologias antagônicas, sinta mais o peso da história e uma necessidade de maior participação social e política, com vistas ao combate da alienação, opressão e violência promovidas pelas guerras e pelos governos totalitários. Nesse sentido, Irving Howe, analisando a situação do romancista político do século XX, nome pelo qual ele designa o romancista engajado, observa que:

O romancista político de nosso século sente as pressões da ideologia muito mais intensamente que seus predecessores do século XIX. Ele vê a ideologia não enquanto sintoma de alguma doença estranha, mas como a carga e o desafio da história: necessária em tempos de crise social, atemorizante em seu rigor e, precisamente, por poder ser utilizada de forma tão terrível, uma tentação perigosa demais para aqueles que dela mais necessitam. Ainda assim, ele reconhece que a ideologia deve ser confrontada, a história não permite outra alternativa; pois, como uma descoberta da física atômica, a ideologia por si só não é boa nem má, sendo uma forma de pensamento que permite o mais amplo espectro de aplicação moral. (HOWE, 1998, p. 157) 
É sob o peso dessa carga histórica do seu tempo que o romancista da primeira metade do século XX, pressionado pelas ideologias de direita, de centro e de esquerda, sente a necessidade urgente de tomar partido frente às questões cruciais pelas quais o mundo atravessa e, assim, há a tomada de posição refletida, lúcida e voluntária que, no plano literário, vai exigir do escritor uma radicalidade ética acompanhada de uma radicalidade estética. Desse modo, o romance engajado do século XX se alimenta do real, ou seja, do contexto histórico-político-social. Por essa perspectiva, podemos pensar que ele se nutre daquilo que Alcmeno Bastos denomina de "matéria de extração histórica":

Como matéria de extração histórica deve ser entendida a matéria objeto de alguma forma de registro documental, escrito ou não, de que resulta permanecer na memória coletiva de uma determinada comunidade. A matéria de extração histórica, para merecer tal designativo, deve apresentar satisfatório grau de familiaridade para um leitor medianamente informado e poder ser recuperada mediante processo alusivo. (BASTOS, 2000, p. 9)

Dito de outro modo, o romance engajado trava um profundo diálogo com a história, com a intenção de problematizar as suas crises políticas e sociais, procurando "testemunhar o paradoxo que é o homem no mundo" (SARTRE, 1994, p. 64). Os principais temas abordados por ele estão geralmente associados aos grandes eventos que sacudiram o século XX e as implicações que tiveram na vida social e política do homem. A Revolução Russa, as duas grandes Guerras Mundiais, a Guerra Civil Espanhola, a quebra da bolsa norte-americana em 1929, a Guerra Fria, a Revolução Cubana, as guerras de descolonização na África e na Ásia, os golpes de estado nos países latino-americanos, o comunismo soviético, o nazismo alemão, o fascismo italiano, espanhol e português, e as ditaduras latino-americanas são largamente representados nos romances engajados.

Pelo fato de os escritores engajados terem o comprometimento humanitário como linha-mestra de seus projetos literários e, por isso, terem, embora burgueses, uma mentalidade antiburguesa, serem resistentes à ideologia dominante, contrários, principalmente, às 
ideologias nazista e fascista, esses elementos comuns entre eles, aquilo que Alfredo Bosi (2002) denominou de o mesmo fundo axiológico, acompanhados também de temáticas comuns, possibilitou um intenso diálogo no campo literário entre os romancistas engajados.

Dessa forma, as afinidades ideológicas entre os romancistas engajados vão convergir também em afinidades estéticas, através da apropriação de técnicas narrativas inovadoras realizadas entre eles, de modo que elas se tornaram quase um patrimônio comum da literatura da primeira metade do século XX.

Se há um consenso de que a ideia de engajamento e de literatura engajada surgiu e se consolidou na França, também não é menos verdade que as primeiras grandes realizações engajadas no campo literário se deram na literatura norte-americana, através dos romancistas William Faulkner, Ernest Hemingway e John dos Passos, que influenciaram, direta ou indiretamente, não só a sua, mas também as gerações seguintes de escritores comprometidos com as causas sociais e humanas. Nesse sentido, Benoît Denis (2002) observa que os escritores franceses encontraram a forma adequada para o romance engajado inspirando-se em romancistas norte-americanos e russos e, assim, criaram o que ele chama de romance simultaneísta. Segundo ele:

Inspirando-se nos romancistas americanos (Faulkner, Dos Passos, Hemingway) ou russos (Pilniak e Babel), Malraux, Sartre e, num grau menor, Camus, escolheram praticar o romance simultaneísta. Esquematicamente resumida, essa técnica consiste em recusar a onisciência do narrador e a substituí-la por uma polifonia de vozes narrativas: a narrativa focaliza sucessivamente uma série de personagens das quais ela assume o ponto de vista situado e limitado. A linearidade da narrativa encontra-se assim quebrada em uma série de fragmentos justapostos, sem que nenhuma voz os ligue e articule explicitamente: longe de apresentar a perfeita inteligibilidade do romance tradicional, a história aparece aqui como obscura, cheia de vazios e incertezas, sujeita a interpretações divergentes. (DENIS, 2002, p. 91)

Embora haja controvérsia quanto à nomenclatura "romance simultaneísta" utilizada por Denis, até porque há outras para denominar o mesmo tipo de romance, achamos válida a observação pelo fato de que ela evidencia a importância que os escritores norte-americanos 
tiveram na concepção de uma literatura de denúncia social e política, sem abdicar das convenções estéticas, influenciando não apenas os franceses, os fundadores do engajamento, mas também toda a literatura ocidental, inclusive, e principalmente, as literaturas de língua portuguesa, conforme veremos um pouco mais adiante. Nesse aspecto também é válido lembrar a afirmação feita por Benjamin Abdala Júnior na introdução de A escrita Neo-realista (1981):

\begin{abstract}
A literatura ocidental evoluiu pelos caminhos de um novo realismo, como resposta às tensões sociais originadas pela grande crise econômica em processo desde 1929. Destacam-se, ao longo da década de 30, as produções dos escritores norte-americanos, como Ernest Hemingway, John dos Passos, William Faulkner, John Steinbeck, Erskine Caldwell, etc., que vieram a influenciar as literaturas americanas e europeias, invertendo o vetor da transmissão cultural da América para a Europa. (ABDALA JÚNIOR, 1981, p. 1)
\end{abstract}

Em relação à polifonia, técnica narrativa base do romance simultaneísta, conforme a concepção de Denis, achamos válido lembrar também uma observação feita por Irving Howe sobre a manipulação simultânea de várias ideias que deve ser feita pelo romancista político com o objetivo de dar voz às ideias muitas vezes divergentes dentro do romance e, assim, respeitar a ideia de oposição, que deve ser levada em consideração mesmo contra as próprias predisposições, anseios e fantasias do escritor.

Como um dialético engenhoso, o romancista político deve ser capaz de manipular várias ideias ao mesmo tempo, vê-las em suas relações hostis, mas ainda assim interdependentes, e compreender o modo no qual ideias no romance são transformadas em algo diferente do que as ideias de um programa político. (HOWE, 1998, p. 7)

Nesse sentido, a observação de Howe vai ao encontro da anterior, de Denis, pelo fato de evidenciar a importância da polifonia para o romance engajado, permitindo o confronto de pontos de vista divergentes, o que por sua vez possibilita ao leitor entrever a complexidade social e política, levando-o, através da reflexão, a perceber as contradições históricas e 
entender que não há uma única interpretação para o mesmo fato e sim várias, conforme pensa Linda Hutcheon (1995), para quem não há uma única história e sim "histórias" no plural.

Retornando ao pioneirismo dos escritores norte-americanos, é importante lembrar, também, que as inovações formais introduzidas por eles no romance do século XX eram acompanhadas de uma temática de preocupação social e política, de modo que seus projetos literários conciliavam a realização estética com a realização ética.

William Faulkner, considerado pela maioria da crítica literária como o melhor romancista americano de todos os tempos, valeu-se de uma narrativa polifônica e fragmentada para abordar, em $O$ som e a fúria, a decadência da aristocracia rural do sul dos Estados Unidos, e em Luz em agosto, utilizando as mesmas técnicas narrativas, tematizou a vida de pessoas que vivem à margem da sociedade, abandonadas e sem nenhuma perspectiva de futuro.

Ernest Hemingway, utilizando-se de uma linguagem objetiva, seca, de sentenças curtas, beirando à linguagem jornalística, que fez escola entre os seus contemporâneos, teve a guerra como tema frequente de seus romances, de modo que os três principais conflitos da primeira metade do século XX (as duas guerras mundiais e Guerra civil espanhola) são abordados por ele. Em Adeus às armas, denunciou os horrores da Primeira Guerra Mundial, tendo como mote o romance entre dois jovens e como cenário a Itália arrasada pelo conflito. Já em Por quem os sinos dobram, o cenário da guerra é a Espanha arrasada pela guerra civil; enquanto que em Ilhas da corrente, emerge o horror da Segunda Guerra Mundial.

John dos Passos, em sua USA trilogy, formada pelos romances Paralelo 42 (1930), 1919 (1932) e O grande capital (1936), abordou a história social norte-americana associada ao crescimento da economia, denunciando, principalmente, a exploração da Primeira Guerra Mundial feita pelos Estados Unidos, fato que levou o país à hegemonia econômica e militar que perdura até os dias de hoje. Para tanto, o romancista lançou mão da técnica do 
contraponto e da polifonia, orquestrando várias vozes narrativas independentes, juntamente com a técnica do mosaico, através da qual inseria, na narrativa, manchetes de jornais, propagandas e cenas cinematográficas de rua.

Outro escritor que deve figurar entre os romancistas engajados norte-americanos é John Steinbeck. Embora não tenha sido adepto das experimentações modernistas como foram Faulkner, Hemingway e Dos Passos, a sua obra se caracteriza por ter como tema central os efeitos que a crise da Depressão de 1929 provocou na vida dos norte-americanos, principalmente na vida dos mais pobres que, na época, constituíam a maior parte da população. O seu mais prestigiado romance, As vinhas da ira, de 1939, aborda a viagem de uma família de Oklahoma, que perde as suas terras por conta da quebra da bolsa de valores e, para sobreviver, se vê obrigada a migrar para o estado da Califórnia.

Dessa forma, esses escritores foram os precursores do engajamento literário realizado no século XX, fornecendo, inclusive, a forma adequada do romance engajado aos franceses. Nesse sentido, é a partir do romance norte-americano que Jean-Paul Sartre irá não apenas teorizar o engajamento literário, mas também produzir os seus próprios romances engajados, como A náusea (1938), Idade da razão, Sursis e Com a morte na alma, nos quais alia o engajamento literário à sua filosofia existencialista, cujas principais primícias eram de que o ser humano é fruto de suas escolhas e, assim, a tomada de posição, lúcida, refletida e voluntária exigida pelo engajamento está em total consonância com o existencialismo.

Aliás, essa combinação entre a literatura engajada e a filosofia existencialista parece ser mesmo o cerne da teorização feita pelo filósofo francês sobre o engajamento literário, pois ela aparece não só nos romances de Sartre, mas também nas obras literárias dos seus contemporâneos André Malraux e Albert Camus.

André Malraux, para quem "toda a arte é uma revolta contra o destino do homem" concebeu seus principais romances (Os conquistadores, Estrada real e A condição humana), 
tendo como pano de fundo a revolução nacionalista chinesa e como elemento condutor uma profunda reflexão sobre os dilemas éticos da consciência do indivíduo num tempo em que era necessária uma tomada de posição, pois o destino da humanidade estava em jogo e não havia lugar para meios-termos. Para Lucien Goldmann (1976, p. 52), ele é, juntamente com Victor Serge, o único escritor conhecido do período entreguerras "que fez da revolução proletária um elemento estrutural importante de suas criações".

Quanto a Albert Camus, embora não tenha sido exatamente um existencialista e tenha tido uma complicada ruptura pessoal/intelectual com Sartre, o absurdo da existência humana que permeia os romances $O$ estrangeiro (1942) e A peste, guarda muitas semelhanças com a doutrina existencialista do ex-colega, além, é claro, de sua escrita literária guiar-se pelo compromisso humanitário do engajamento, mostrando, assim, como quer Sartre (2006), o paradoxo que é o homem no mundo. Em questões éticas e políticas, de acordo com Benoît Denis (2002, p. 283), Camus comportava-se como "um moralista, antes de tudo preocupado com a defesa de visão humanista do homem”. E foi com esse propósito que ele engajou a sua escrita.

Mas, na Europa, não foram apenas os escritores franceses que se apropriaram de temas e técnicas narrativas utilizadas pelos escritores norte-americanos. Os italianos também beberam na mesma fonte. Nesse aspecto, vale lembrar o comentário feito por Alfredo Bosi (2002), de que a narrativa dos romancistas italianos Elio Vitorini e Cesare Pavese tinha por modelo o romance Adeus às armas, de Ernest Hemingway. De acordo com Bosi:

A prosa direta, aparentemente jornalística, deste grande escritor seduzia aqueles intelectuais europeus nutridos de uma cultura literária milenar refinada e devedora de tradições clássicas, românticas, simbolistas... A proposta neo-realista passava também a significar a libertação de uma prática de escrita que estaria, por sua própria ancianidade estética, vinculada a ideais e valores já ultrapassados. Novamente, a resistência ético-política buscava traduzir-se em uma resistência no plano das opções narrativas e estilísticas. (BOSI, 2002, p. 127) 
Dessa forma, eles se utilizaram da técnica narrativa apropriada de Hemingway para abordar as terríveis experiências pelas quais passou a Itália no período das guerras mundiais e do fascismo de Mussolini e, assim, deram início a uma literatura engajada em solo italiano, berço de milenares tradições artísticas clássicas, no que foram seguidos posteriormente pelos compatriotas Carlo Levi e Vasco Pratolini.

Essa literatura engajada, ou de resistência, comprometida com os valores humanos e preocupada com situações político-sociais, que se inicia em solo norte-americano e depois recebe uma teorização na Europa, também vai encontrar ressonância na América Latina. Nos países de língua espanhola, a princípio, ergueram-se para participar desse diálogo as potentes vozes do guatemalteco Miguel Angel Astúrias e do cubano Alejo Carpentier, cujos romances O senhor presidente, do primeiro, e $O$ reino deste mundo, do segundo, são clássicos do romance engajado latino-americano. Depois deles vieram outros romancistas engajados, sobretudo a partir da década de 50, do mesmo quilate literário dos dois pioneiros, como o colombiano Gabriel Garcia Marquez, os peruanos Mário Vargas Llosa e Jose Maria Arguedas, os mexicanos Carlos Fuentes e Juan Rulfo, o chileno Manuel Rojas e paraguaio Augusto Roa Bastos.

E, no Brasil, ela encontra ressonância muito antes dos nossos vizinhos hispânicos. Já nos anos 30, surgem diversos romances de Graciliano Ramos, Jorge Amado, José Lins do Rego, Erico Veríssimo, Rachel de Queiroz e Amando Fontes, com traços de engajamento literário. Eles vão encetar um diálogo com a literatura portuguesa, contribuindo para o surgimento do Neorrealismo português, e, posteriormente, vão também ser importantes para a formação das literaturas nacionais dos países africanos de língua portuguesa, sobretudo Angola, Cabo Verde e Moçambique. 


\subsection{O romance engajado de língua portuguesa}

O romance engajado em língua portuguesa, produzido no Brasil a partir dos anos 30 e em Portugal a partir da década de 40, conforme nos aponta Edvaldo Bergamo (2008, p. 52), notabilizou-se pelo compromisso ideológico de "denunciar as injustiças sociais e as contradições político-econômicas, registrando a marginalização e a degradação do espoliado" nas sociedades brasileira e portuguesa, consideradas historicamente injustas por eles. Nesse sentido, Bergamo elenca as principais características dessa produção literária que foi predominante entre as décadas de 30 e 50 nas literaturas de língua portuguesa:

Em linhas gerais, o romance engajado dos anos 30 e 40 do século XX define-se pelas seguintes características: expressão de convicto comprometimento político do intelectual, concepção materialista da existência, apresentação de camadas sociais oprimidas como matéria ficcional, consideração do indivíduo sob uma perspectiva de classe, análise dos meios de produção existentes e sentido teleológico que implica a confiança no homem e a certeza da superação das adversidades encontradas. (BERGAMO, 2008, p. 198-199)

Conforme afirmamos anteriormente, o romance engajado em língua portuguesa surge primeiramente no Brasil nos anos 30 e só na década seguinte vai ter os seus representantes em Portugal. De 1930 a 1939 é possível identificar na chamada literatura de ênfase social brasileira quase 30 romances com as características de literatura engajada. Nesse período, Amando Fontes publicou Os corumbás e a A lua do Siriri; Erico Veríssimo, Clarissa, Música ao longe, Caminhos cruzados, Um lugar ao sol e Olhai os lírios do campo; Graciliano Ramos, Caetés, São Bernardo, Angústia e Vidas secas; Jorge Amado, País do Carnaval, Cacau, Suor, Jubiabá, Mar morto e Capitães de areia; José Lins do Rego, Menino de engenho, Doidinho, Banguê, Moleque Ricardo, Usina, Pureza, Pedra bonita e Riacho doce; e Rachel de Queiroz, O quinze, João Miguel, Caminho de pedras e As três Marias. Não 
podemos deixar de lembrar também o romance A bagaceira, de José Américo de Almeida, publicado em 1928, tido como o iniciador do romance social brasileiro dos anos 30 .

Embora nem todos eles expressem um conteúdo político explícito, ou mesmo possuam todas as características do romance engajado de língua portuguesa elencadas na citação anterior de Edvaldo Bergamo, todos apresentam uma preocupação com o aspecto social da realidade brasileira e o destino do ser humano, mostrando aquilo que Jean-Paul Sartre (2006) denomina de "o paradoxo que é o homem no mundo", que caracteriza, de um modo geral, a literatura engajada, pois essa escolha culmina no desvendamento do mundo ao leitor, nesse caso específico, o desvendamento da realidade social brasileira.

Aqui é importante lembrar que o romance imbuído de abordagem social não é uma novidade da literatura brasileira dos anos 30, pois ela já existia nos romances naturalistas e na ficção de Lima Barreto. Segundo Antonio Candido (2006), o que diferencia esses romancistas da ficção naturalista é a superação do otimismo patriótico e a adoção de um tipo de pessimismo feita por eles. Assim, enquanto o Naturalismo

focalizava o homem pobre como elemento refratário ao progresso, eles desvendavam a sua situação na sua complexidade, voltando-se contra as classes dominantes e vendo na degradação do homem uma consequência da espoliação econômica, não do seu destino individual. (CANDIDO, 2006, p. 160)

Há que se ressaltar também que essa literatura é herdeira direta das conquistas formais e ideológicas realizadas pelos modernistas de 22. Conforme Edvaldo Bergamo (2008), ela é fruto da conciliação dessas conquistas com as reivindicações sociais da década de 30, juntamente com a retomada de algumas premissas do realismo do século XIX.

Esses romances, abordando várias faces da realidade brasileira, foram lidos pelos portugueses e essa leitura ajudou na emergência de uma literatura portuguesa também engajada, em contraposição à estética literária defendida pelos integrantes da Revista Presença, na época predominante na cena literária portuguesa. Segundo informação de 
Benjamin Abdala Júnior (2003), o poeta Ribeiro Couto, adido cultural da embaixada brasileira em Lisboa, foi o responsável por levar os intelectuais portugueses à leitura dos brasileiros.

A leitura dos romancistas brasileiros foi a revelação de um modo novo de se fazer romance para os portugueses, diferente da maneira a qual estavam habituados na época, de forma a indicar um caminho que a ficção portuguesa poderia trilhar, conforme atesta a declaração de António Ramos de Almeida:

Os romances de Graciliano Ramos, José Américo de Almeida, José Lins do Rego, Jorge Amado, Amando Fontes, Raquel de Queirós (sic), Erico Veríssimo chegavam de chofre como um duche sobre uma sensibilidade leitora e crítica embutada pelo decadentismo mórbido do romance europeu que usara e abusara das escavações psicológicas. $\mathrm{O}$ romance brasileiro irrompia como qualquer coisa de diferente, repleto de força e de vida de um humanismo novo, onde os problemas concretos e reais da sociedade e do indivíduo se misturaram uns nos outros como os cipós da vegetação selvática. (...) A vida social do Brasil (...) aparecia num realismo direto e espontâneo aos olhos dos leitores e dos escritores portugueses habituados a literatismo convencional do romance francês, onde nos casos individuais, patológicos, isolados, decadentes, ímpares se repetiam aleatórios e vários, já sem o conteúdo ou interesse universal. Nada de admirar, portanto, que a sua experiência tivesse resultado fecunda entre nós, que tivesse sido aproveitada pelos nossos mais novéis e conscientes ficcionistas como um caminho a trilhar, como uma "picada" aberta a golpes de heroísmo através da mata virgem e hostil. (ALMEIDA, 1965, p. 3)

Ainda sobre a impressão causada pelos romances brasileiros em Portugal, Adolfo

Casais Monteiro (1964) observa que o interesse por eles era por conta dos tipos humanos que essa literatura revelava, um quadro humano muito diferente do português, devido à grande miscigenação racial e cultural e pelo referver de várias forças sociais, revelados numa época em que a unidade do povo brasileiro era um processo vivo. Mas, acrescenta ele, a mais forte impressão gerada em seus espíritos foi a maneira com que os romancistas brasileiros souberam arrancar da sua época uma visão profundamente humana e múltipla do mundo.

Vale lembrar que na época as condições históricas e políticas vividas por portugueses e brasileiros eram muito semelhantes, e que elas foram determinantes para a formação dos 
romancistas engajados dos dois países, que por sua vez vão se refletir diretamente em seus romances. Portugal contava, desde 1927, com um regime político de contornos fascistas, o Estado Novo de António Salazar, enquanto que no Brasil a Revolução de 30, de início com ideais democráticos, em 1937 se tornaria um regime autoritário, o Estado Novo de Getúlio Vargas, também com uma ideologia muito próxima do fascismo. E ainda não podemos esquecer que no mesmo período a ameaça nazista e a franca ascensão do fascismo pela Europa gerava uma preocupação constante com o destino da humanidade. Nesse sentido, Edvaldo Bergamo, analisando o diálogo estabelecido entre os romancistas brasileiros e portugueses do período, faz a seguinte observação:

O contexto histórico e estético da década de 30 e a orientação política preferencialmente de esquerda aproximaram diversos romancistas brasileiros como Jorge Amado, Amando Fontes, Erico Veríssimo, José Lins do Rego, Rachel de Queiroz e Graciliano Ramos. Não é de estranhar que num período de grande agitação ideológica, homens de letras expressaram suas convicções, conciliando militância política e literatura de ênfase social, como bem demonstra a produção empenhada do período, representativa de um projeto literário coletivo que agregava a geração que produziu o romance social brasileiro de 30. (BERGAMO, 2008, p. 70)

Dessa forma, os escritores brasileiros e portugueses engajados foram forjados num dos mais turbulentos períodos históricos que a humanidade já teve, no qual seus países também estavam sob o jugo de regimes políticos autoritários, opressores e repressivos, fato que, segundo Benjamin Abdala Júnior (2007), vai gerar determinados laços de solidariedade entre eles por serem formados na mesma atmosfera ideológica da frente popular antifascista que contagiou os intelectuais do mundo todo na década de 30. Nesse sentido, numa outra obra, o mesmo autor afirma:

Nessa situação histórico-cultural formaram-se, com análogas preocupações sociais, as literaturas brasileira e portuguesa da época, cronologicamente: primeiro a brasileira, e, depois, próximo da Segunda Guerra Mundial, a portuguesa. Entre os brasileiros figuram Graciliano Ramos, José Lins do Rego, Jorge Amado, Erico Veríssimo e Amando Fontes, que, como os ficcionistas norte-americanos, influenciaram profundamente a prosa de ficção portuguesa da década de 40, como as produções de Alves Redol, 
Carlos de Oliveira, Manuel da Fonseca, José Cardoso Pires, Fernando Namora e outros. (ABDALA JÚNIOR, 1981, p.2)

Nesse aspecto, as situações políticas semelhantes nos dois países fizeram com que as afinidades ideológicas (éticas) se convertessem também em afinidades estéticas, as quais abordaremos um pouco mais adiante. Em relação à contribuição dos norte-americanos, lembrada por Benjamin Abdala Júnior, à qual também já nos referimos anteriormente denominando-os como os escritores que forneceram um modelo para o romance engajado do século XX, é válido lembrar um depoimento do romancista Vergílio Ferreira, um dos principais nomes do Neorrealismo português, em que ele comenta a importância que teve a leitura dos escritores brasileiros e norte-americanos para a sua formação literária de leitor e escritor:

A minha geração, como é sabido, interessou-se vivamente e foi largamente
influenciada pela literatura brasileira - de um Jorge Amado, Graciliano
Ramos, Lins do Rego, Erico Veríssimo. A razão desse interesse é
perfeitamente explicável: ela tem que ver ainda com determinada situação
política. Para uma literatura de imediata acção social como a do famigerado
Neo-realismo, nós não tínhamos modelos senão os brasileiros. A própria
literatura estrangeira - nomeadamente americana - que pudesse interessar-
nos, dificilmente a poderíamos conhecer senão de traduções brasileiras. Foi
assim que eu conheci Por quem os sinos dobram, de Hemingway (ao tempo
um livro mais ou menos clandestino), As vinhas da ira, de Steinbeck, Filho
nativo, de R. Wrigth, USA, de Dos Passos, etc. Mas outro livro que
subterraneamente conhecemos - como esse fundamental La condition
humaine de Malraux - nós só os sabíamos ler com os olhos de um
imediatismo social e político. A literatura brasileira, portanto, foi a única
solução que se nos apresentou. (FERREIRA, 1981, p. 160)

O depoimento de Vergílio Ferreira atesta a existência, na primeira metade do século $\mathrm{XX}$, de um grande diálogo intertextual entre os escritores que pautavam seus textos literários aliando uma conduta ética a uma escolha estética, em que os romancistas norte-americanos surgem como pioneiros e os brasileiros aparecem com um papel de destaque dentro do contexto das literaturas de língua portuguesa. Esse diálogo que ocorre independentemente da nacionalidade do escritor, haja vista a participação de autores norte-americanos, franceses, 
italianos, espanhóis, portugueses, brasileiros e hispano-americanos, se constituiu, principalmente, através de uma grande afinidade ideológica, de defesa dos direitos humanos tão ameaçados naquele período, que é o motor da literatura engajada do século XX. Por esse aspecto, pelo fato de o engajamento literário ter se tornado um fenômeno sem fronteiras, ele adquiriu um caráter supranacional, cuja ênfase "está na reivindicação de uma aliança entre arte e sociedade, traduzida em inconformismo e comprometimento social, uma vez que os radicalismos políticos em voga exigiam uma atitude participante do escritor consciente de sua missão" (BERGAMO, 2008, p. 54).

O caráter supranacional que a literatura engajada adquiriu no século XX, fez Benjamin Abdala Júnior (2007) pensar na existência de um macrossistema literário no âmbito das literaturas de língua portuguesa. Esse macrossistema englobaria não só as literaturas brasileira e portuguesa, mas também as novas literaturas que surgiram no idioma português a partir dos anos 40 nas ex-colônias portuguesas em África: Angola, Cabo Verde, Guiné-Bissau, Moçambique e São Tomé e Príncipe.

O macrossistema literário de língua portuguesa, na concepção de Benjamin Abdala Júnior (2007), constitui-se como um campo comum de contatos entre os sistemas literários nacionais, que se alimenta do passado comum que compartilham e da diversidade que há nas atualizações realizadas em cada uma das literaturas de língua portuguesa.

O passado comum se dá pelo uso da mesma língua e pelas condições históricas das relações entre Portugal e as ex-colônias e das relações entre as próprias ex-colônias, haja vista a grande troca cultural que houve entre o Brasil e as outras ex-colônias, desencadeadas pelo tráfico de escravos; enquanto que as atualizações realizadas dentro de cada sistema literário apresenta aquilo que cada um tem de específico, de diferente do outro dentro do macrossistema, ou seja, são os aspectos particulares de cada um deles, denominados por 
Abdala Júnior (2007) de "aspectos internos" em contraposição dialética aos "aspectos externos", que correspondem aos aspectos gerais.

Dessa forma, esse passado comum fez com que surgisse um "fenômeno de convergência cultural" (ERVEDOSA, 1979, p. 105) entre os países de língua portuguesa, que explica as afinidades que vão ocorrer no campo literário. A convergência cultural, que Benjamin Abdala Júnior (2007, p. 37) vai renomear de "ecologia cultural", constrói um dinâmico traço de união entre eles e vai favorecer "a circulação de modelos de ruptura" nos momentos de reivindicação e ruptura política e cultural nas ex-colônias portuguesas africanas. Foi o que aconteceu em Angola quando eclodiu o movimento cultural "Vamos descobrir Angola", embrião do movimento revolucionário que lutaria pela independência política do país. Na origem do movimento, os jovens intelectuais angolanos espalhados por Luanda e pelas universidades de Coimbra e Lisboa tinham como exemplo o Modernismo brasileiro de 1922. Nas palavras do angolano Carlos Ervedosa:

\begin{abstract}
Eles sabiam muito bem o que fora o movimento modernista brasileiro de 1922. Até eles havia chegado, nítido, o "grito do Ipiranga" das artes e letras brasileiras, e a lição dos seus escritores mais representativos, em especial de Jorge de Lima, Ribeiro Couto, Manuel Bandeira, Lins do Rego e Jorge Amado, foi bem assimilada.

O exemplo destes escritores ajudou a caracterizar a nova poesia e ficção angolanas, mas é, certamente, num fenómeno de convergência cultural que poderemos encontrar as razões das afinidades das duas literaturas. A mesma amálgama humana, frente a frente nas duas margens do Atlântico tropical, em presença de condições ecológicas quase idênticas, teria de conhecer reações e comportamentos muito semelhantes. (ERVEDOSA, 1979, p.105106)
\end{abstract}

A declaração de Carlos Ervedosa encontra eco na voz de vários escritores angolanos, como, por exemplo, neste depoimento de José Luandino Vieira, feito numa entrevista a Denira Rozário, quando foi questionado sobre as influências que tinha recebido.

Para os escritores nascidos entre 48 e 70, a influência da literatura brasileira é marcante; recebíamos revistas do Brasil e não recebíamos de Portugal. Havia lido Raquel de Queiroz, Jorge Amado, José Lins, Erico Veríssimo e Guimarães Rosa. Já tínhamos lido a geração do Nordeste brasileiro quando 
começamos a ler a geração neo-realista portuguesa, que entronca com a nossa formação literária dos anos 57. São mais essas duas grandes influências. Os angolanos são mais sensíveis à cultura brasileira, há maior proximidade cultural entre em Angola e Brasil. (ROZÁRIO, 1999, p. 194)

O depoimento de Luandino Vieira, além de corroborar a declaração de Carlos Ervedosa sobre a importância dos modernistas brasileiros para a formação dos escritores angolanos da sua geração, também vai ao encontro da ideia do macrossistema literário de língua portuguesa, de Benjamin Abdala Júnior, ao inserir neste diálogo os neorrealistas portugueses, que, como temos visto, dialogam profundamente com a geração modernista brasileira de 30.

O mesmo processo ocorrido em Angola também se deu em Moçambique no período de formação da literatura nacional, conforme nos atestam as declarações do poeta moçambicano José Craveirinha, em entrevista concedida aos professores Omar Thomaz e Rita Chaves, ao falar sobre os elementos da cultura brasileira conhecidos em Moçambique na época de sua adolescência, e sobre a sua relação com o universo literário.

Nós na escola, éramos obrigados a passar por um João de Deus, Dom Dinis etc., os clássicos de lá. Mas chegava uma certa altura que nós nos libertávamos e então enveredávamos para uma literatura "errada": Graciliano Ramos e por aí afora. Tínhamos nossas preferências, e, na nossa escolha, pendíamos desde o Alencar... A nossa literatura tinha reflexos da literatura brasileira. Então, quando chegou o Jorge Amado, estávamos em casa. Jorge Amado nos marcou muito, porque aquela maneira de expor as histórias fazia pensar em muitas situações que existiam aqui...

(...)

Os neo-realistas tiveram muita repercussão aqui. Mas depois veio aquela avalancha de brasileiros: $O$ Cacau e $O$ suor, do Jorge Amado,o Jubiabá... Eu era um dos grandes fãs da Rachel de Queiroz. Eu e muitos, todo o grupo. Íamos para a Livraria Spanos esperar pelo $O$ Cruzeiro, ansiosos pela crônica da Rachel. Quando soube que ela tinha sido contemplada com o Prêmio Camões, fiquei emocionado. (CHAVES, 2005, p. 226-240)

Podemos considerar o depoimento de Craveirinha sobre as impressões causadas nos moçambicanos pelos escritores modernistas brasileiros e neorrealistas portugueses como algo extensivo a toda sua geração, conforme é possível perceber pelo uso da segunda pessoa do 
plural, o que denota a enunciação de um sujeito coletivo. Mas não apenas em Angola e Moçambique há ressonâncias do Modernismo brasileiro. Em Cabo Verde também há marcas explícitas da presença da literatura modernista brasileira no período da reivindicação e afirmação cultural, conforme podemos constatar na declaração do sociólogo brasileiro Gilberto Freyre, feita quando esteve em viagem à ex-colônia portuguesa e transcrita pelo cabo-verdiano, Manuel Ferreira.

\begin{abstract}
A linguagem do romancista Jorge Amado, por exemplo, ou a do romancista José Lins do Rego ou a do romancista Erico Veríssimo, ou a do poeta Manuel Bandeira, ou do poeta Jorge de Lima tem hoje imitadores entre os jovens de Cabo Verde, da África, do próprio Portugal. Imitadores que, nessa imitação antes ativa que servil, se utilizam de equivalentes regionais nativos das expressões portuguesas ou mestiças empregadas por vigorosos escritores brasileiros de hoje sob o impacto de condições antes regionais que nacionais da vida brasileira. (FERREIRA, 1967, p. 97-98)
\end{abstract}

Excluindo-se a ideologia luso-tropicalista do autor que permeia a declaração e a utilização do termo "imitadores" (apesar de atenuado pela observação de que a imitação é ativa e não servil), incompatível com qualquer pesquisa atual em literatura comparada, a assertiva mostra como a literatura modernista brasileira circulou por Cabo Verde e, principalmente, o aspecto mais positivo dessa circulação, colaborando para o surgimento de uma literatura cabo-verdiana moderna que dialogava diretamente com o seu modelo e com o Neorrealismo português, fato que não é difícil de verificar nos textos literários cabo-verdianos escritos no período. Outro dado importante da declaração de Freyre é a confirmação da existência de um intenso diálogo entre as literaturas brasileira, portuguesa e as novas literaturas em português que estavam surgindo na África, provocado, como já sabemos, pela atmosfera ideológica comum que levou, primeiramente, escritores brasileiros e, depois, os portugueses e africanos ao engajamento literário.

Em tempo, queremos fazer uma ressalva de que por mais que tenhamos utilizado a palavra "influência", tanto em nosso texto quanto nas citações das quais nos servimos, o 
sentido com o qual tencionamos empregá-la não era em hipótese alguma com o propósito de subordinar uma literatura à outra ou um escritor a outro, tornando um devedor ao outro. E, sim, com o propósito de mostrar que houve uma grande afinidade ideológica que levou a uma afinidade estética entre os escritores da primeira metade do século $\mathrm{XX}$, que tinham preocupações humanas, sociais e políticas semelhantes, que por sua vez desencadeou um ruidoso diálogo literário que ainda hoje se faz ouvir o seu eco, pois conforme observa Benoît Denis (2002, p. 304), o engajamento literário não acabará nunca "porque ele é maneira de determinar uma ética da literatura e porque todo escritor exigente deve, num momento ou outro, interrogar-se sobre o sentido da sua iniciativa".

Por outro lado, tínhamos o intento de mostrar, também, que houve sim escritores pioneiros, que forneceram modelos e caminhos que foram seguidos por outros, mas nem por isso a literatura desses outros escritores que vieram depois se tornou uma mera cópia dos primeiros, totalmente devedora deles.

Dessa forma, pensamos a questão da influência literária não como algo que possui a originalidade e a imitação em seus polos, e sim conforme pensa Benjamin Abdala Júnior (1981), como um processo de transferência, distribuição e desenvolvimento de formas literárias, que se realiza através da intertextualidade, por meio da qual um texto é elaborado como resultado de outros textos, através de um trabalho poético de absorção e transformação, pois "ninguém cria do nada" (ABADALA JÚNIOR, 2007, p.44) e todo escritor se insere numa tradição literária existente e cria a partir dela. 


\subsection{A intertextualidade nos romances engajados de língua portuguesa}

Para a sequência de nossa reflexão, torna-se necessária uma rápida abordagem do conceito de "intertextualidade", concebido por Julia Kristeva a partir do dialogismo de Mikhail Bakhtin (1997).

Segundo Julia Kristeva (1974), para Bakhtin a palavra literária é um cruzamento de superfícies textuais, onde se realiza um diálogo entre diversas estruturas: o escritor, o destinatário e o contexto cultural atual ou anterior.

Nesse sentido, o texto literário situa-se numa corrente histórica e social, constituída por textos que o escritor lê e na qual se insere ao reescrevê-los. Daí então ocorre a transformação da diacronia em sincronia, e à luz dela a história linear revela-se uma abstração. Dessa forma, o escritor participa da história literária através de uma escrituraleitura que transgride essa abstração. Assim, o texto literário produzido é uma prática de uma estrutura significante que se realiza em função ou em oposição à outra estrutura.

A partir dessas considerações de Mikhail Bakhtin, Julia Kristeva estabelece uma concepção espacial do funcionamento poético da linguagem e define três dimensões do espaço textual, onde os diferentes diálogos se realizam através das operações dos conjuntos sêmicos e das sequências poéticas:

Essas três dimensões são: o sujeito da escritura, o destinatário e os textos exteriores (três elementos em diálogo). O estatuto da palavra define-se, então, a) horizontalmente: a palavra no texto pertence simultaneamente ao sujeito da escritura e ao destinatário, e b) verticalmente: a palavra no texto está orientada para o corpus literário anterior ao sincrônico. (KRISTEVA, 1974, p. 63)

Kristeva ressalta que nesse universo discursivo o destinatário consta apenas como discurso, fundindo-se, então, ao outro discurso (o outro livro), àquele em relação ao qual o escritor escreveu seu texto, de forma "que o eixo horizontal (sujeito-destinatário) e o eixo 
vertical (texto-contexto) coincidem para revelar um fato maior: a palavra (o texto) é um cruzamento de palavras (de textos), onde se lê, pelo menos uma outra palavra (texto)" (KRISTEVA, 1974, p. 64).

Lembrando que em Bakhtin esses dois eixos, denominados de "diálogo" e "ambivalência", não estão claramente distintos, ela ressalta que isso não tira a importância da descoberta que o teórico russo introduz na teoria literária:

Todo texto se constrói como mosaico de citações, todo texto é absorção e transformação de um outro texto. Em lugar da noção de intersubjetividade, instala-se a de intertextualidade e a linguagem poética lê-se pelo menos como dupla. (KRISTEVA, 1974, p. 64)

Dessa forma, Kristeva cria o termo "intertextualidade" para melhor definir a designação do dialogismo bakhtiniano da escritura simultaneamente considerada como subjetividade e comunicabilidade, observando que, por conta desse diálogo, a noção de "pessoa-sujeito da escritura" desaparece para ceder o espaço para a da "ambivalência da escritura", observando também que este termo implica a recíproca inserção da história no texto e do texto na história, como duas vias que se unem na narrativa.

Assim, para Bakhtin, na leitura de Julia Kristeva, a escrita de um texto literário é a leitura do corpus literário anterior, noção que implica ver o texto como absorção e réplica a outro texto. Utilizando-se, também, do conceito de paragrama, do linguísta Ferdinand de Saussure, ela reforça essa concepção do texto literário como escritura-leitura:

O texto literário se insere no conjunto dos textos: é uma escritura-réplica (função ou negação) de um outro (dos outros textos). Pelo seu modo de escrever, lendo o corpus literário anterior ou sincrônico, o autor vive na história e a sociedade se escreve no texto. A ciência paragramática deve, pois, levar em conta uma ambivalência: a linguagem poética é um diálogo de dois discursos. Um texto estranho entra na rede da escritura: esta o absorve segundo leis que estão por descobrir. Assim, no paragrama de um texto, funcionam todos os textos do espaço lido pelo escritor. (KRISTEVA, 1974, p. 98) 
Para reforçar essa concepção, Julia Kristeva lembra o significado que o verbo "ler" tinha na antiguidade, um significado que ficou esquecido e que vem bem ao encontro da conceituação de dialogismo e de intertextualidade:

O verbo "ler" tinha, para os antigos, uma significação que merece ser lembrada e valorizada, com vistas a uma compreensão da prática literária. "Ler" era também "recolher", "colher", "espiar", "reconhecer os traços", "tomar", "roubar". "Ler" denota, pois uma participação agressiva, uma apropriação ativa do outro. "Escrever" seria o "ler" convertido em produção, indústria: a escritura-leitura, a escritura paragramática seria a aspiração de uma agressividade e uma participação total. (KRISTEVA, 1974, p. 98)

Nesse aspecto, para Kristeva, a linguagem poética (literária) se constrói através de um diálogo de textos em que toda sequência se constrói em relação à outra, oriunda de um outro corpus, de forma que ela é duplamente orientada: primeiro para o ato de reminiscência, que é a evocação de outra escrita e, segundo, para o ato de intimação, que é a transformação de escrita evocada. Nesse sentido, um livro remete a outros livros e confere a eles um novo modo de ser, elaborando também a sua própria significação.

Desse modo, o conceito de intertextualidade concebido por Julia Kristeva, a partir do dialogismo de Mikhail Bakhtin, ajusta-se perfeitamente aos nossos objetivos de pesquisa para abordar o diálogo entre os escritores engajados de língua portuguesa, ocorrido no século XX.

Por essa perspectiva, todo texto literário em português é escrito a partir de uma tradição literária preexistente em língua portuguesa que, por sua vez, insere-se na tradição literária ocidental. Dessa forma, não há dependência e nem imitação entre as obras literárias engajadas escritas em língua portuguesa no século passado que apresentam determinados elementos comuns, como a temática e as técnicas narrativas. Nesse sentido, "o que ocorre normalmente é a adoção de estratégias discursivas comuns reconhecíveis em mais de um sistema literário, visto que a identidade linguística e cultural torna inevitável o contato" (BERGAMO, 2008, p. 187). 
Assim, conforme bem observou Benjamin Abdala Júnior (2003, p. 67) há "processos de apropriação dentro das literaturas de língua portuguesa" que ocorrem através do "aproveitamento de sugestões temáticas e de processos narrativos, no terreno literário, e como expressão de afinidades eletivas, campo político" (BERGAMO, op. cit., p. 109), pois, no caso da literatura engajada, os escritores "estão comprometidos com a transformação e suas perspectivas críticas não lhes permitem descartar a experiência alheia" (ABDALA JÚNIOR, 2007, p. 39) com o intuito de alcançarem a conscientização dos seus leitores.

Dessa forma, é através dos processos de apropriação que se realiza esse diálogo intertextual entre os escritores engajados de língua portuguesa. Sobre o conceito de apropriação, é válido esclarecer que Benjamin Abdala Júnior buscou-o na teorização feita por Affonso Romano de Sant'Anna em Paródia, paráfrase e cia (1985), a partir de estudos anteriores realizados pelos russos Yuri Tynianov e Mikhail Bakhtin, e adaptou-a ao seu estudo dos processos de empréstimos e transferências de formas literárias ocorridas nas literaturas de língua portuguesa.

Partindo da ideia de Affonso Romano de Sant'Anna (1985) de que o escritor apropriador contesta o conceito de propriedade dos textos-objetos, desvinculando-os de seus sujeitos anteriores e sujeitando-os a uma nova leitura; aliada ao conceito de intertextualidade de Julia Kristeva (1974), Abdala Júnior observa:

Ninguém cria do nada. Há a matéria da tradição literária que escritor absorve e metamorfoseia nos processos endoculturativos, desde a apreensão "mais espontânea" dos pequenos "causos" populares, ditos populares, canções etc., da chamada oralitura ("literatura" oral) até os textos "mais auto-reflexivos" da literatura erudita. Ocorre, nesse sentido, um apropriação "natural" das articulações literárias sem que o próprio futuro escritor se aperceba de sua situação de ser social e de "porta-voz" de um patrimônio cultural coletivo. Quando o escritor escreve, pode julgar que o texto é apenas seu, não tendo consciência de que na verdade é a sociedade que se inscreve através dele. $\mathrm{Na}$ sua escrita está uma confluência de práxis coletivas, desde a específica da série literária até às outras, relativas à sua atividade noutros campos sêmicos do trabalho social. O escritor engajado procura ter consciência dessa inserção social. (ABDALA JÚNIOR, 2007, p. 44-45) 
Desse modo, Abdala Júnior concebe a apropriação de duas formas: como um processo inconsciente em que o escritor realiza a apropriação sem se dar conta disso; e como uma estratégia discursiva consciente da parte dele, em que toma por empréstimo estruturas narrativas já utilizadas por outros escritores para elaborar a sua obra, ao mesmo tempo em que conscientemente inscreve a sociedade em seus textos. Pelo fato de procurar ter consciência de tais processos, tanto da inserção social na literatura quanto dos procedimentos literários de que utiliza, o escritor engajado se insere nessa segunda perspectiva.

O diálogo intertextual entre os escritores engajados de língua portuguesa ocorrido a partir da década de 30 é desencadeado por uma afinidade ideológica entre os escritores que se viam, primeiramente, como companheiros que estavam numa mesma trincheira, lutando contra a alienação, a violência, a injustiça e a miséria humana, com o objetivo de tornar o mundo um lugar um pouco melhor, tendo como arma a palavra literária. Nesse sentido, vale lembrar uma declaração do romancista brasileiro Erico Veríssimo sobre um encontro que teve com escritores portugueses durante uma viagem realizada a Portugal em 1959.

Estou sentado entre dois portugueses que admiro e estimo, e que, após alguns minutos de conversação, já posso considerar meus amigos: Maria Lamas e Vergílio Ferreira. Eu conhecia a odisséia dessa brava intelectual portuguesa perseguida pela polícia salazarista e que tem passado alguns anos de sua vida em forçados exílios. É uma senhora de meia-idade, de pele trigueira e cabelos grisalhos, belas feições serenas, manso o gesto, suave a voz... Quanto a Vergílio Ferreira, que terá pouco mais de quarenta anos, é um homem cuja face inspira simpatia e confiança. Fala pouco e sabe escutar. Nota-se-lhe nos olhos uma expressão de desalento, de desesperança. Conheço dele apenas um livro, um de seus primeiros romances, ainda do tempo em que os críticos lhe haviam pespegado o rótulo de neo-realista. É possível que Ferreira tivesse pertencido a essa escola, mas nos seus últimos romances tem-se agora revelado um escritor aberto aos problemas existenciais do homem. (...) Não sei, não pergunto e creio até que não desejo saber se Vergílio Ferreira leu algum de meus livros. Estou certo de que entre os intelectuais portugueses que me têm recebido tão cordialmente haverá muitos - provavelmente a maioria - que nunca abriram um livro de minha autoria ou, se abriram, não gostaram ou ficaram indiferentes. Nada disso, porém, me preocupa. O importante é que eles parecem ver em mim um companheiro de lutas democráticas, Isso, sim, me alegra. (VERISSIMO, 1976, p. 210-211) 
Essa afinidade ideológica entre companheiros de lutas democráticas levou os romancistas engajados brasileiros e portugueses a uma afinidade estética que resultou na apropriação de temas e técnicas narrativas pelos segundos em relação aos primeiros, e assim compartilharam "modelos semelhantes de articulação literária" (ABDALA JUNIOR, 2007, p. 65). Dessa forma, os escritores portugueses debruçaram-se sobre a realidade social e política portuguesa, abordando temas que diziam respeito sobre a vida e o desenvolvimento da nação, assim como os brasileiros haviam feito alguns anos antes, utilizando-se de técnicas narrativas semelhantes. Do mesmo modo, posteriormente, os jovens escritores africanos de língua portuguesa, sobretudo os angolanos, cabo-verdianos e moçambicanos, vão se identificar com a literatura produzida pelos modernistas brasileiros e neorrealistas portugueses e vão utilizar as suas formas literárias como modelos para retratar suas terras e suas gentes e, principalmente, para construir uma literatura nacional e também uma nação.

Neste ponto é importante lembrar uma observação feita por Antonio Candido (2004) sobre o fato de uma técnica narrativa ser utilizada por vários escritores. Para o crítico brasileiro, a técnica empregada por um escritor é um instrumento de trabalho e, por isso, pode ser utilizada por mais de um deles, de forma que podem usá-la para expressar mais de um conteúdo, ou seja, se a técnica ou a forma é semelhante, os conteúdos expressados por ela podem ser diferentes. No caso dos brasileiros e portugueses, os assuntos abordados por eles diferenciavam-se por tratarem de assuntos específicos de cada um dos países. Ou seja, conforme o pensamento de Edvaldo Bergamo (2008), o compartilhamento da mesma série ideológica e de temas e estratégias formais semelhantes não impedem que a obra literária seja permeada por variantes locais, que devem ser observadas na comparação literária como elementos de diferenciação que a caracterizam.

Ainda em relação à apropriação e compartilhamento de temas e técnicas narrativas, também achamos válido lembrar o pensamento do crítico literário russo Victor Zhirmunsky 
(1994, p.208) sobre a adaptação do modelo literário apropriado. Para ele, cada influência literária envolve a transformação social do modelo que é adotado, ou seja, a sua reinterpretação e adaptação às condições literárias e sociais, e à individualidade ideológica, psicológica e artística do autor em questão.

De acordo com o pensamento de Candido e Zhirmunsky está a conclusão que chegou Benjamin Abdala Júnior (2007, p. 277) ao final de sua análise sobre o engajamento e as apropriações e transferências realizadas dentro das literaturas de língua portuguesa. Para ele, ficou evidente que "as experiências de cada país podem ser transmitidas para outro, em face da utilização do mesmo código linguístico, das equivalências culturais e das aproximações históricas. São experiências apropriadas com um dominante próprio de cada país."

\subsection{Marcas reformuladas pela posteridade: Erico Verissimo e Pepetela}

Erico Verissimo foi um dos escritores brasileiros mais importantes do chamado romance de 30 e, conforme já vimos no decorrer deste capítulo, seu nome figura entre os dos romancistas Jorge Amado, Graciliano Ramos, José Lins do Rego, Rachel de Queiroz e Amando Fontes, como um escritor que deu a sua contribuição para o desenvolvimento de uma literatura de caráter engajado em Portugal e nos países africanos de língua portuguesa, conforme atestam as várias declarações de que já transcrevemos e às quais acrescentamos algumas outras observações e depoimentos, com o objetivo de não deixar dúvidas sobre a recepção de sua obra e a importância que ela teve nos países de língua portuguesa.

Nesse sentido, o professor José Édil de Lima Alves (2006) observa que num levantamento realizado nos periódicos portugueses Seara Nova, O Diabo, Sol Nascente, Vértice e o Globo, entre os anos de 1934 e 1946, o nome de Erico Verissimo foi citado em 
pelo menos 26 artigos, acrescentando que embora haja artigos desfavoráveis, a grande maioria se refere a ele de forma elogiosa, até mesmo quando a crítica não é lá tão favorável assim, citando como exemplo a crítica feita por Mário Dionísio ao romance Olha os lírios do campo, publicada na edição de $O$ Diabo, de 15 de abril 1939.

O romancista Vergílio Ferreira, em seu livro Um escritor apresenta-se (1981), ao comentar sobre os escritores que serviram de modelo para ele e a sua geração, reafirma a importância dos modernistas brasileiros e deixa entrever uma possível influência de Erico Verissimo:

Outro aspecto que normalmente se esquece é que todo o artista começa partindo de outro artista. (....) A quem foi que recorremos? Aos brasileiros. Daí que Jorge Amado tenha exercido uma razoável influência no Alves Redol, que Graciliano Ramos tenha exercido uma influência bastante forte no Carlos de Oliveira e que, no meu caso pessoal, Um lugar ao sol, de Erico Veríssimo - a primeira obra de arte moderna que conheci -, me tenha também influenciado. (OLIVEIRA, 1981, p. 165)

As afinidades estéticas e ideológicas entre as obras literárias de Jorge Amado e Alves Redol, e de Graciliano Ramos e Carlos de Oliveira, foram estudadas respectivamente por Edvaldo Bergamo (2008) e Benjamin Abdala Júnior (1981), ambos com resultados plenamente satisfatórios, enquanto José Édil de Lima Alves (2006) pesquisou a afinidade ideológica assumida por Vergílio Ferreira em relação a Erico Verissimo sem, no entanto, lograr resultados satisfatórios, ou seja, a afinidade entre eles não se confirmou no plano estético, como o próprio pesquisador reconhece.

Nos países africanos de língua portuguesa a obra de Erico Verissimo também teve uma boa recepção. O seu nome quase sempre é citado ao lado de outros modernistas brasileiros, por críticos literários e professores que estudam as relações literárias entre o Brasil, Angola, Cabo Verde e Moçambique, e também por escritores desses países como um dos autores brasileiros lidos em terras africanas que tiveram importância no processo de formação das suas respectivas literaturas. 
A professora Rita Chaves (2005), num ensaio sobre as literaturas angolana e moçambicana (Angola e Moçambique: o lugar das diferenças nas identidades em processo), cita Erico Verissimo entre os escritores brasileiros que deram a sua contribuição para a formação das duas jovens literaturas. Segundo ela:

Invertendo a rota que trouxe os escravos que viriam construir o Brasil, daqui seguiriam, sobretudo a partir da década de 50, páginas e páginas de ficção e poesia (brasileira) que seriam recebidos com muito entusiasmo pela intelectualidade de Angola e Moçambique.

Percorrendo rotas sinuosas para evitar a censura, os livros levavam notícias de nossa experiência cultural, alimentando imagens que, sem corresponder à realidade de um cotidiano ainda amargo no terreno das contradições sociais e da discriminação racial, foram catalisadas pelos escritores africanos na clave progressista e participaram da formação do pensamento nacionalista urbano nesses dois países. Jorge Amado, Graciliano Ramos, José Lins do Rego, Rachel de Queirós, Erico Verissimo, e poetas como Manuel Bandeira e Ribeiro Couto tornaram-se nomes de grande densidade no repertório de leituras nas duas costas africanas. (CHAVES, 2005, p. 257-258)

Para comprovar a assertiva de Rita Chaves basta lembrarmos as declarações do escritor angolano José Luandino Vieira e do sociólogo brasileiro Gilberto Freyre, já citadas anteriormente neste capítulo, às quais acrescentamos uma declaração de outro importante escritor angolano, Artur Carlos Maurício Pestana dos Santos, conhecido no mundo literário por Pepetela, que em uma entrevista concedida ao jornalista Wilson Bueno, do jornal $O$ Estado de São Paulo, cujo trecho foi reproduzido por Rita Chaves e Tania Macêdo no livro Portanto...Pepetela (2009), reconhece ter sido influenciado por vários romancistas brasileiros, entre os quais Erico Verissimo:

Reconheço grande influência dos escritores brasileiros que lia e relia quando muito jovem: Jorge Amado, Graciliano Ramos, José Lins do Rego, Erico Verissimo. Foram os meus mestres. Dos atuais, destaco João Ubaldo Ribeiro, entre muitos que admiro. (CHAVES; MACÊDO, 2009, p. 36).

O professor Edvaldo Bergamo, ao final do seu livro Ficção e convicção, no qual abordou as afinidades estéticas e ideológicas existentes entre o romance do escritor brasileiro Jorge Amado e os romances dos neorrealistas portugueses Alves Redol, Soeiro Pereira 
Gomes, Manuel da Fonseca e Fernando Namora, apresenta uma hipótese mais do que plausível: o romance engajado das décadas de 30 e 40 do século passado deixou marcas que foram aproveitadas e reformuladas pela posteridade:

\begin{abstract}
Nossa hipótese é de que o projeto literário dos anos 30 e 40 do século XX de revalorização do realismo e de aprofundamento da questão social, do qual são paradigmas as obras de Jorge Amado e dos neo-realistas portugueses, deixou marcas que foram aproveitadas e/ou reformuladas pela posteridade. $\mathrm{Na}$ época contemporânea, certamente o desenvolvimento cultural abriu novas fronteiras de exploração e novas trilhas de expansão para a literatura e a arte em geral. Nesse sentido, o romance continua sendo um dos principais gêneros literários da atualidade, revigorado por aspectos diversos. No plano temático, aparecem com destaque a reavaliação da história, a representação das minorias raciais e sexuais e o enfoque nos problemas dos povos póscoloniais. No plano formal, preponderam as estratégias narrativas que utilizam como recursos dominantes a intertextualidade, a autoreferencialidade e a auto-reflexividade. (BERGAMO, 2008, p. 199)
\end{abstract}

Como exemplo dessa permanência da revalorização do realismo e do aprofundamento da questão social que norteou o projeto literário dos escritores engajados da primeira metade do século passado, apresentamos algumas marcas temáticas e formais da literatura do romancista brasileiro Erico Verissimo que foram apropriadas e reformuladas, já na década de 80, pelo escritor angolano Pepetela.

Dentre as marcas temáticas e formais semelhantes existentes entre os dois romancistas estão o gênero romance de fundação, a saga familiar e o diálogo com a história, utilizadas na trilogia O tempo e o vento (1997), por Erico Verissimo, e em Yaka (1998) por Pepetela, bem como a estrutura narrativa em forma de contraponto, a polifonia e a metaficção, empregadas pelos dois escritores.

Na trilogia O tempo e o vento (1995), constituída pelos romances $O$ continente (1995d), O retrato (1995e) e O arquipélago (1995c), Erico Verissimo narra a história da fictícia família Terra-Cambará, de simples colonos a detentores do poder político e econômico, num período de 200 anos entremeados por momentos de guerra e paz, onde estão presentes os conflitos contra os vizinhos castelhanos e as revoluções regionais e nacionais 
pelas quais passou o Rio Grande do Sul: a Guerra das Missões, Guerra da Cisplatina, Revolução Farroupilha, Guerra do Prata, Guerra do Paraguai, Revolução Federalista, Revolução de 23 e Revolução de 30. Para concebê-la, o escritor valeu-se da intercalação de dois níveis temporais, um sincrônico e o outro diacrônico.

Pepetela, em Yaka, tendo como fio condutor a história dos Semedo, família de colonos portugueses, aborda um período de 85 anos da história angolana, de 1890 até meados de 1975. São abordados, no romance, fatos históricos como a expansão portuguesa rumo ao interior da África após o Tratado de Berlim (1884/1885) e o Ultimato Inglês (1890), a queda da monarquia portuguesa, as duas guerras mundiais, a ascensão do salazarismo, as diversas revoltas dos nativos contra os colonos portugueses, o início de guerra da libertação nacional, a Revolução dos Cravos e os momentos que antecederam a independência angolana em 1975.

\subsection{Gênero, tema e estratégias narrativas comuns utilizadas por Erico Verissimo e}

\section{Pepetela}

A análise das técnicas narrativas utilizadas por Erico Verissimo e Pepetela para a elaboração de $O$ tempo e o vento e Yaka será realizada de forma mais aprofundada nos capítulos seguintes. A seguir faremos uma breve exposição da temática, gênero e das principais técnicas narrativas utilizadas pelos dois escritores. 


\subsubsection{A saga familiar}

A etimologia da palavra "saga" vem do vocábulo islandês segja, cujo significado é narrar ou contar. Em norueguês arcaico, segundo Massaud Moisés (2004), o termo passou a designar "história". Nesse sentido, em termos literários, saga familiar designa uma narrativa cuja trama se desenvolve em torno da trajetória de várias gerações de uma mesma família, ou seja, aquilo que Mikhail Bakhtin (1998) denominou de "romance familiar e de gerações".

De acordo com Robert Scholes e Robert Kellog (1977), nas narrativas nórdicas esse desenrolar genealógico servia de fundo para o desenvolvimento de estórias de cunho histórico, mítico ou religioso. Através da mescla de "fatos verídicos, folclóricos e imaginários relatavam as histórias de famílias como Laxdaela Saga, de autor desconhecido" (MOISÉS, 2004, p. 469).

Embora a origem da palavra saga seja nórdica, há outras narrativas com características de saga familiar bem mais antigas que as encontradas na Islândia, como, por exemplo, a Bíblia, na qual história e religião são abordadas por meio de sucessivas gerações da família de Abraão. Há também o exemplo grego, onde Regina Zilberman (2004) viu na tragédia de Ésquilo, a trilogia Orestéia, que aborda a vida de três gerações da família de Agamêmnon, imbricadas com a história, os mitos e a política gregas, como o modelo das sagas familiares modernas. Segundo ela:

Essa crônica de guerra e de dois povos é, por seu turno, uma crônica familiar. Histórias de família já tinham sido matéria de epopéias, mas Ésquilo procede à articulação fundamental: a história do Átridas fica imbricada à história da própria Grécia, pois, se o conflito entre Atreu e Tiestes têm causas internas - a rivalidade dos irmãos, o adultério e o crime -, os atritos vivenciados entre seus respectivos descendentes - Menelau e Agamêmnon, de um lado; Agamêmnon e Egisto, de outro - não podem ser dissociados de um plano mais geral, de natureza política e militar.

(...)

A tragédia de Ésquilo ata a saga familiar à história política de uma cidadeEstado, unidade administrativa fundamental conforme o modelo de governo 
adotado pelos gregos no século V a.C, quando a Orestéia foi apresentada ao público ateniense pela primeira vez. (ZILBERMAN, 2004, p. 146)

Tanto a trilogia O tempo e o vento, de Erico Verissimo, quanto Yaka, de Pepetela, seguem o modelo grego, através da articulação entre literatura e história, com o entrelaçamento da história individual da família com a história política e social da nação.

\subsubsection{Narrativas de fundação}

Os romances que compõem a trilogia O tempo e o vento e Yaka, pelo fato de abordarem ficcionalmente a história de uma família associada ao desenvolvimento da nação, também podem ser caracterizados como narrativas de fundação, inserindo-se numa corrente da literatura que tem sua origem no Romantismo, no período de emergência e consolidação do sentimento nacional que propiciou o surgimento de narrativas ficcionais que tratavam a questão da nação como uma "comunidade imaginada", conforme termo cunhado por Benedict Anderson (2008) para designar "o nós coletivo" que a ideia representava. De acordo com Doris Sommer (2004), os ideais iluministas difundidos no mundo todo durante o século XIX embasaram o surgimento dos romances de fundação.

Segundo Lúcia Helena (2005, p.169-179), a narrativa de fundação procura "escrever a nação por meio da ficção, atribuindo-se correlações entre o localismo e nacionalismo", e caracteriza-se "por ser um fenômeno híbrido, parte artístico-literário, parte histórico-político, no qual, por meio da ficção, criam-se "comunidades imaginadas", ou seja, textos que se articulam com a história mundial e nacional, mas cuja vida se implanta, toma corpo e revelase através da literatura."

Dessa forma, a narrativa ou romance de fundação caracteriza-se também como um romance histórico, no qual entrelaçam-se ficção, história e política, e da maneira como foram 
elaborados por Pepetela e Erico Verissimo, com características do Realismo e do Modernismo literário, também se inserem no contexto da literatura engajada praticada no século $\mathrm{XX}$, conforme veremos nos capítulos seguintes.

\subsection{3. $O$ contraponto}

O contraponto é uma técnica importada da música pela literatura. Em música, essa técnica consiste em combinar, simultaneamente, duas ou mais vozes melódicas, sendo que cada uma delas é independente uma da outra, mantendo-se uma relação de contraste entre elas, que por sua vez cria uma harmonia. Dessa forma, o contraponto se dá através da harmonização dessas diferentes vozes melódicas, ou seja, através da harmonização da polifonia.

A transposição da técnica do contraponto para a literatura se faria através da criação de um romance constituído por várias intrigas e personagens paralelas, de modo que a narrativa fosse fragmentada e formasse um todo harmonioso através do contraste polifônico das diversas vozes constituintes. Essa transposição ficou mundialmente conhecida depois que Aldous Huxley utilizou-a em Contraponto, romance publicado em 1928. Mas é sabido que antes de Huxley outros escritores já haviam utilizado esse recurso narrativo. Dentre eles, John dos Passos, no romance Manhattan transfer, publicado em 1925, André Gide, em Os moedeiros falsos de 1926, e Somerset Maugham, em O carrossel de 1904.

Mas há também quem veja a utilização dessa técnica musical muito antes dos autores citados. Mikhail Bakhtin (1997) afirma que Leonid Grossman (1967) sustentou, no seu ensaio "As leis da composição", a tese de que a base da composição dos romances de Dostoiévski é musical, através da intercalação de duas ou mais histórias que se cruzam, se completam pelo 
contraste, e relacionam-se umas às outras pelo princípio musical da polifonia. Para Bakhtin, a transposição para a linguagem literária da linguagem da teoria musical de M. I. Glinka, cuja tese era de que tudo na vida é contraponto, equivaleria dizer que para Dostoiévski "tudo na vida é diálogo, ou seja, contraposição dialógica." (Op. cit., p. 44.). E seria a partir dessa proposição que o filósofo e teórico russo desenvolveria a sua tese do caráter polifônico dos romances de Dostoiévski.

Aldous Huxley, em Contraponto (1982), através do recurso metaficcional, na esteira Dostoiévski e Gide, enuncia pela voz narrativa de Philip Quarles como seria a adaptação dessa técnica musical na literatura:

A musicalização da ficção. Não à maneira simbolista, subordinando o
sentido ao som. (...) Meditar sobre Beethoven. As mudanças de modo, as
transições abruptas. (A majestade alternando com a brincadeira, por
exemplo, no primeiro movimento do Quarteto em Si Bemol Maior. A
comédia sugerindo subitamente solenidades prodigiosas e trágicas no
scherzo do Quarteto em Dó Sustenido Menor.) Ainda mais interessantes, as
modulações, não somente dum tom para um outro, mas de um modo para
outro. Um tema é exposto, depois desenvolvido, mudado,
imperceptivelmente deformado, até que, se bem que reconhecivelmente o
mesmo, ela se tenha tornado de todo em todo diferente. Nas séries de
variações, o processo é levado um passo mais longe. Por exemplo, essas
incríveis variações sobre um tema de Diabelli. O âmbito inteiro do
pensamento e da emoção, e tudo isso em relação orgânica com uma pequena
ária de valsa ridícula. Por isto num romance. Como? As transições abruptas
não apresentam nenhuma dificuldade. O que precisamos é de um número
suficiente de personagens, e intrigas paralelas, contrapontísticas. Enquanto
Jones assassina sua mulher, Smith empurra o carrinho do filho no parque.
Alternam-se os temas. (HUXLEY, 1982, p. 299-300) O romance contrapontístico pensado e elaborado por Huxley seria constituído por diversos grupos de personagens e diversas intrigas paralelas, que seriam regidas pelo narrador de forma simultânea, de modo que ele pudesse passar abruptamente de um grupo de personagens ou de uma história para outra. A estratégia narrativa ideal para realizar essa narração simultânea é a "alternância", que, segundo Tzvetan Todorov (1976, p. 234), consiste em contar simultaneamente duas ou mais histórias, "interrompendo ora uma ora outra, pra retomá-la na interrupção seguinte". 
Em $O$ tempo e o vento, a técnica do contraponto é utilizada para a articulação da história que se passa no sobrado, no tempo diacrônico, com as diversas histórias dos integrantes da família Terra-Cambará, passadas no tempo sincrônico, e ainda com os episódios intermediários presentes em $O$ continente e $O$ arquipélago. Em Yaka, essa técnica é utilizada para inserir a história da família cuvale de Vilonda e também a narração feita pela voz narrativa da estátua yaka pode ser considerada como um contraponto.

\subsubsection{A polifonia}

Assim como a técnica do contraponto, a polifonia também é um termo tomado de empréstimo pela literatura junto à música, e significa, a grosso modo, o efeito da combinação harmoniosa de instrumentos ou vozes que soam simultaneamente.

Embora não tenha sido o primeiro a identificar a utilização da polifonia como recurso narrativo, Mikhail Bakhtin (1997) foi o primeiro a realizar uma teorização do seu uso na literatura, partindo dos estudos pioneiros realizados pelo seu compatriota Leonid Grossman sobre a presença do contraponto e da polifonia dos romances de Dostoievski.

Tomando por objeto de estudo a obra literária de Dostoievski, na qual ele vê a polifonia como a peculiaridade fundamental que ela possui, Bakhtin (1997) vai definir a polifonia narrativa como uma "multiplicidade de vozes e consciências independentes e imiscíveis" (Ibid., ,p. 4) em relação umas às outras. Dessa forma, a essência da polifonia vai consistir na independência que essas vozes guardam entre si, mas ao mesmo tempo combinando-se "numa unidade de ordem superior à da homofonia" (Ibid., p. 21), ou seja, harmonizando-se no todo da narrativa. 
Numa obra literária, essa diversidade de vozes que constitui a polifonia pode se dar através da estruturação da narrativa pela técnica do contraponto, pelo fato de que cada uma das histórias que compõem a narrativa constituem-se como vozes independentes; pela existência de mais de um narrador, desde que possuam pontos de vista diferentes; e por meio dos diálogos travados entre as personagens, através do contraste das suas ideias divergentes, como acontece, por exemplo, nos romances de Dostoievski, nos quais, segundo Bakhtin (Ibid. p. 15), o modo da conversa ou da discussão faz emergir diferentes pontos de vista que podem "dominar alternadamente e refletir matizes diversos de confissões opostas". Nesse sentido, Irene Machado (1995, p. 93) observa que no romance polifônico, as vozes que entram para sua constituição "são sujeitos plenivalentes daquilo que enunciam porque são, sobretudo, ideias em confronto, são pontos de vista em constante interação".

Por essa razão, por ser um romance sobre ideias, onde diferentes ideias coexistem e se interagem, o próprio Bakhtin denominou o romance polifônico dostoievskiano de "romance ideológico". Daí então que essa técnica narrativa inaugurada pelo romancista russo tenha se disseminado pelo século $\mathrm{XX}$, tornando-se um dos principais recursos narrativos utilizados pelos escritores engajados.

Em O tempo e o vento a polifonia surge nos episódios intermediários de $O$ continente, constituídos por várias vozes anônimas, pela voz feminina que enuncia um ponto de vista diferente do masculino em toda trilogia, e pelas discussões políticas que acontecem nos serões do sobrado em $O$ retrato e $O$ arquipélago, nas quais diferentes ideologias são enunciadas. Em Yaka, a polifonia se dá pela existência de vários narradores e nas discussões políticas ocorridas no bar do Lima. 


\subsubsection{A metaficção}

A metaficção, também denominada de metanarrativa, insere-se na função metalinguística, conforme a teoria das funções da linguagem concebidas pelo linguista russo Roman Jakobson (1974), como o processo em que linguagem fala sobre ela mesma, ou seja, quando o código linguístico é utilizado para explicar o próprio código.

Nesse sentido, como uma das possibilidades de realização da metalinguagem, a metaficção define-se como a narrativa de ficção que se autoquestiona. De acordo com Linda Hutcheon (1984), ela é a "ficção sobre ficção - isto é, ficção que inclui em si mesma um comentário sobre sua própria identidade narrativa e/ou lingüística" de forma explícita. A teórica também define o recurso metaficcional como um processo narcisístico em que a narrativa se autocontempla e deixa visível o seu processo de criação e desenvolvimento, procedimento que ela denomina de "mimese do processo". Dessa forma, para ela, a metaficção é uma "narrativa narcisística", de modo que "o adjetivo qualificativo escolhido para designar essa autoconsciência textual não tem sentido pejorativo, mas principalmente descritivo e sugestivo, como as leituras alegóricas do mito de Narciso" (Ibid.)

Já para David Lodge (1992, p. 206), a metaficção é constituída por "romances e histórias que chamam a atenção para o seu status ficcional e para seus próprios procedimentos de composição", ou, como diz Hayden White (1994) para a sua natureza de artefato literário.

Segundo Linda Hutcheon (1984), Roland Barthes considera Flaubert, com sua "consciência artesanal da produção literária", como o iniciador desse processo na modernidade, continuado por Mallarmé, André Gide, Aldous Huxley, James Joyce, Svevo e Thomas Mann, através da introdução da fusão da literatura e pensamento crítico sobre a própria literatura, observando que eles foram fundamentais para o desenvolvimento do romance metaficcional pós-moderno. 
Nesse sentido, para Robert Scholes (1970, p. 29), "a metaficção assimila todas as perspectivas críticas dentro do próprio processo ficcional", ou seja, tudo o que possa possibilitar um autoquestionamento. Dentre os esquemas metaficcionais utilizados por ela, Gustavo Bernardo elenca os seguintes:

Romances sobre uma pessoa escrevendo um romance; contos sobre uma pessoa lendo um conto até se ver de repente dentro do conto que está lendo; histórias que comentam as convenções da própria história como capítulos, parágrafos ou enredos, romances não-lineares que possam ser lidos não apenas do princípio para o final; notas de rodapé que continuam a história enquanto a comentam; romances em que o autor é personagem do seu próprio romance; histórias que conversam com o leitor, antecipando, frustrando ou ironizando suas reações à história; personagens que se preocupam com a circunstância de se encontrarem em meio a uma história de ficção; histórias que incorporam aspectos e referências de teoria ou crítica da literatura; obras que criam biografias de escritores imaginários; enredos que sugerem aos leitores que eles se encontram em mundos tão ficcionais quanto aquele dos enredos. (BERNARDO, 2007)

A principal dessas estratégias metaficcionais utilizadas como desencadeadoras do autoquestionamento, da mimese do processo, é, segundo Zênia de Faria (2008), a inclusão, na obra literária, de uma personagem-escritor, que está escrevendo ou planeja escrever um livro. Para ela, essa estratégia

é uma das que mais caracterizam a mimese do processo, ou que a colocam em marcha, na medida em que podemos acompanhar os meandros da criação, podemos observar o personagem-escritor diante de suas dúvidas, de seus impasses, de seu questionamento de como levar a termo o projeto de escrita que se propôs a realizar. (FARIA, 2008, p. 3)

Essa estratégia da inclusão do romancista no romance ou do livro dentro do livro é também chamada de mise em abyme, ou perspectiva em abismo, quando ela corresponde "a inserção de uma narrativa dentro da outra que apresente uma relação de semelhanças com aquela que contém" (DÄLLENBACH, 1977, p. 18), ou seja, que haja uma reduplicação da história contada. Para Linda Hutcheon (1984), a mise em abyme é uma das "modalidades explícitas" de metaficção presentes em textos "diegeticamente autoconscientes". Segundo ela, 
as obras literárias metaficcionais elaboradas com a perspectiva em abismo, podem apresentar três tipos diferentes da utilização desse recurso narrativo: simples reduplicação, duplicação repetida in infinitum e duplicação aporística (o fragmento deve incluir a obra onde se encontra incluído).

Em O tempo e o vento o recurso metaficcional é utilizado na forma "mise em abyme duplicação repetida in infinitum", através da personagem Floriano Cambará, que planeja escrever um romance histórico, e em Yaka, por meio das memórias que Alexandre Semedo escreve e, ao final, tomamos conhecimento que a obra literária que escrevem é o próprio livro que estamos lendo. 


\section{O PROJETO LITERÁRIO DE ERICO VERISSIMO}

O principal objetivo do projeto literário de Erico Verissimo era, conforme ele mesmo reconheceu (BRAGA, 1997, p. 31), "realizar um corte transversal da sociedade", desnudando toda a sua hipocrisia e denunciando todo tipo de violência contra o ser humano que ela oculta. Essa opção do autor, o leitmotiv de sua escrita, consistia, segundo Flávio Loureiro Chaves (2001), em elaborar uma literatura que revelasse a engrenagem social e seus mecanismos, de modo que mostrasse o homem na sua dinâmica social e o indivíduo em sua humanidade, ou seja, que os seres humanos fossem apanhados em pleno ato de viver, de acordo com a assertiva de Jean-Paul Sartre (1994, p. 64) de que a obra literária deve ter por objetivo testemunhar e explorar "o paradoxo que é o homem no mundo".

Daí que a sua matéria literária é formada por pedaços da vida e isso explica a sua escolha consciente por uma literatura de abordagem sociológica em detrimento da profundidade psicológica. Dessa forma, a matéria-prima utilizada por Erico Verissimo são os elementos sociais externos, principalmente os históricos e os políticos, que se internalizam em seus romances, conforme a assertiva de Antonio Candido (2000) do "externo que se faz interno", que considera o elemento social como fator da própria construção artística.

Nesse sentido, lembramos uma observação do crítico brasileiro feita a propósito do romance $O$ resto é silêncio (1995i), que exemplifica bem a opção literária de Erico Verissimo:

Como os outros, este romance tem uma grande riqueza em extensão, mas avança pouco em profundidade. Erico Verissimo é, de fato, um romancista horizontal, cujo valor reside na capacidade de organizar um feixe complexo de destinos humanos no sentido da sua inter-relação, da sua projeção grupal - se me permitem. Porque a sua meta é, sem dúvida, apresentar as relações humanas. (CANDIDO, 2004a, p. 69)

Também essa escolha do autor não acontece de forma gratuita. Ela é fruto do momento histórico em que o escritor foi forjado. Lembramos que Erico Verissimo surgiu 
como escritor no período entreguerras e, dessa forma, a sua literatura reflete os dilemas enfrentados pelos escritores do mundo todo num período cindido pelas oposições capitalismo $\mathrm{x}$ comunismo, socialismo $\mathrm{x}$ fascismo, arte $\mathrm{x}$ vida, beleza $\mathrm{x}$ verdade e contemplação $\mathrm{x}$ participação, que resultaram, conforme vimos no capítulo anterior, no surgimento de uma literatura engajada nos Estados Unidos, Europa e América Latina. Assim, a sua escolha por uma literatura de abordagem social, ou seja, engajada, é a sua opção diante de tais dilemas.

Nesse sentido, Antonio Candido (1972b) afirma que Erico Verissimo é um escritor marcado pela década de 30 , década em que ele se definiu como autor e manteve-se fiel às inquietudes do período, sem nenhum prejuízo à evolução de sua arte até ao fim de sua carreira literária. Nas palavras de Candido,

Em Trinta, nós vivemos o problema do realismo, ou neo-realismo, socialista ou não, bem como a incorporação do que as vanguardas do decênio precedente haviam inovado. Vivemos um grande surto do romance, ligado às perspectivas postas em moda pela sociologia e antropologia, como um triunfo do social contraposto às tendências míticas e religiosas. Houve dilaceramentos e disputas, com a formação de um antipolo metafísico e as mais rasgadas polêmicas que marcaram todos nós. (...)

Naquele tempo, Trinta e Quarenta, alguns modernistas se empenharam a fundo na reflexão ideológica ou na ação política direta, como Mário de Andrade e Oswald de Andrade. E isto nos aproximava muito deles, porque o nosso entusiasmo pela Semana de 22 era em parte devido ao fato desses próceres terem feito semelhante evolução; e ao de se ligar ao seu espírito o grande poeta político que era naquele instante Carlos Drummond de Andrade (....)

A eles, como disse, Erico Verissimo está ligado por algumas das suas (nossas) mais constantes preocupações. (CANDIDO, 1972b, p. 42-43)

As inquietudes da sua geração foram transformadas por ele num dos elementos da estrutura literária de seus romances, conforme bem observou Candido ao citar o casal de personagens Noel-Fernanda dos romances Caminhos cruzados (1995a), Um lugar ao sol (1995q) e Saga (1995o), como a encarnação dos dois polos que dividiam os escritores daquela década: "Noel, sonhador, seduzido pela beleza e a gratuidade; Fernanda, prática, puxando-o para os problemas feios da vida." (Ibid.). Vejamos o trecho utilizado pelo crítico para a 
exemplificação dessa observação, em que Fernanda aconselha o namorado/escritor Noel, para que deixe de contemplação e escreva um romance que tenha fortes vínculos com a vida real:

Que importa que um romance tenha arte se não tem humanidade? O que importa é a humanidade.

Ninguém bocejará se você fizer uma história humana. Deixe de literatura. Faça um romance moderno.

O romance deve ser um hino... hino não, é um termo muito convencional, deve ser uma exaltação da coragem, do espírito de camaradagem. Deve dar uma esperança de dias melhores para os que sofrem e para os que lutam...

E deve também ser um libelo aos que por egoísmo, por descuido, por ganância ou por qualquer outra razão não compreendem que todos têm o direito de viver decentemente. (VERISSIMO, 1995q, p.136 )

Diante desse dilema, Erico Verissimo opta pela humanidade, porque para ele a arte e a beleza só tem sentido por causa da vida e da humanidade que elas possam conter. Dessa forma, a sua opção é por uma literatura engajada, comprometida com o ser humano e contra toda espécie de violência sofrida por ele, pois o escritor tinha um verdadeiro horror à violência, e por esse motivo seus romances sempre denunciaram os terríveis males que ela causava à sociedade, seja na forma de reflexões sobre a guerra ou mesmo através de representações de conflitos armados. Essa preocupação constante em sua obra foi vista por Antonio Candido (1972b) como uma "espécie de celebração horrorizada da brutalidade". Nesse aspecto, sobre a violência e as guerras que marcam a história da humanidade, que foram uma preocupação constante no seu período de vida, Erico Verissimo afirma:

Detesto a violência. Quanto às guerras, o diabo é que quem decide são os "sistemas", e não as criaturas humanas. Creio que ninguém pessoalmente deseja a guerra, a não ser um psicopata. A maioria a detesta. Mas os sistemas entram em choque e, estimulados por símbolos patrióticos, lá se vão os homens como rebanhos para o matadouro. Não é mesmo uma coisa terrível? Com tudo quanto se tem inventado e descoberto neste século, os homens poderiam viver decentemente, confortavelmente... e em paz uns com os outros. (DINORAH, 1997, p.43)

Dessa forma, embora Erico Verissimo conservasse o seu otimismo diante da vida e a fé no ser humano, tinha uma visão muito próxima àquela expressada por Louis Althusser em 
Aparelhos ideológicos do estado (2010), pois vislumbrava os homens presos aos "sistemas" como peças de uma Grande Engrenagem, conforme ele denominou no romance $O$ prisioneiro (19951), que retrata a Guerra do Vietnã, incapazes de se libertarem dela e quando influenciados por campanhas patrióticas exacerbadas caminhariam cegos em direção aos intermináveis conflitos que marcam a história.

Para ele, o papel do romancista nesse contexto determinista, desolador e inumano, em que as estruturas políticas decidem a vida das criaturas humanas, deveria ser de lançar luz sobre a realidade do mundo, desnudando-a, mesmo que muitos dos pontos iluminados possam causar náusea no escritor:

Sempre achei que o menos que um escritor pode fazer, numa época de violência e injustiças como a nossa, é acender a sua lâmpada, fazer luz sobre a realidade de seu mundo, evitando que sobre ele caia a escuridão, propícia aos ladrões e aos assassinos. Segurar a lâmpada, a despeito da náusea e do resto. Se não tivermos uma lâmpada elétrica, acendamos o nosso toco de vela ou, em último caso, risquemos fósforos repetidamente, como um sinal de que não desertamos nosso posto. (ANDRADE, 1972, p .9)

Nesse sentido, ele defende uma postura engajada para escritor, comungando com JeanPaul Sartre (2006) a ideia de que o dever do escritor é "tomar partido contra todas as injustiças, de onde quer que venham", com a tarefa de "representar o mundo e testemunhar sobre ele.” E é por essa perspectiva, utilizando a escrita literária como arma, que Erico Verissimo vai se engajar em seus romances e realizar o corte transversal da sociedade, denunciando, por meio deles, a alienação, a miséria e todo tipo de violência cometida contra o ser humano, num dos períodos mais conturbados e violentos da história da humanidade, que vai da Primeira Guerra Mundial até a Guerra Fria.

Embora Erico Verissimo afirme que a tentativa em dar um corte transversal na sociedade começa com a escrita de Caminhos cruzados, romance publicado em 1935, podemos vislumbrar o embrião desse projeto já em 1932, em Fantoches (1995c), livro composto por contos escritos, a maioria deles, na forma de pequenas peças teatrais, e que é a 
primeira obra literária publicada pelo escritor. Ainda que a maioria dos textos possua uma temática universalizante e não contemple a questão social, encontramos dois contos, "Chico" e "Malazarte", em que já transparece a denúncia social tão característica nas obras subsequentes do escritor gaúcho. No primeiro deles, o escritor aborda o problema do menino miserável que vive abaixo da linha de pobreza, que, muitas vezes, ao invés de estar na escola, se obriga a trabalhar, vendendo jornais, para poder ajudar no sustento da família.

Chamava-se Chico. De quê? Ele mesmo não sabia...

- Gente pobre não tem nome... - costumava dizer.

Tinha sete anos. De dia vendia jornais, de noite apanhava bordoada do irmão mais velho, o Zico, que vivia embriagado. (VERISSIMO, 1995f, p. 69)

Flávio Loureiro Chaves (2001) acertadamente enxergou na personagem um arquétipo do garoto Sete-Meis de $O$ resto é silêncio, um menino raquítico de onze anos, que estudava de manhã e à tarde vendia jornais para amenizar a miséria da família. Mas, numa escala maior, também podemos vislumbrar aí, nessa personagem, a origem do coro dos excluídos presente em $O$ continente, em que o escritor dá voz a todos que ficaram à margem da história da saga rio-grandense, representados no romance pelos Caré, uma família de miseráveis cujos homens serviam de bucha de canhão nas guerras e as mulheres de amantes para os homens das famílias abastadas.

Já no conto "Malazarte", Erico Verissimo aborda o tema da decadência das tradicionais famílias patriarcais gaúchas em contraste com a ascensão econômica e social de imigrantes de origem alemã e italiana, que se estabeleceram no século XIX no Rio Grande do Sul, um tema que seria retomado posteriormente em Música ao longe e na trilogia O tempo e o vento. Também aparece no conto a periferia, o bairro Barro Vermelho, espaço onde vivem os pobres, negros, prostitutas, e que seria sempre retomado nas obras subsequentes como contraponto ao centro e outros espaços mais nobres da cidade. 
Para realizar esse corte transversal da sociedade e dar um caráter social e engajado a seus romances, Erico Verissimo se valeu de modernas técnicas narrativas, muitas delas já algum tempo utilizadas na Europa, mas muito pouco conhecidas no Brasil, na esteira de renovação estética do Modernismo de 1922, cuja proposta fora assumida pelo escritor, embora ele nunca tenha se filiado ao movimento. Dessa forma, a radicalidade ética de Erico Verissimo na configuração de seus romances vai ser acompanhada de uma radicalidade estética. Nesse sentido, segundo Maria da Glória Bordini (2003), Clarissa (1995b), o primeiro romance de Erico Verissimo, publicado em 1933, não nasce inocente, pois é tributário do movimento modernista da década anterior e ao mesmo tempo inova o que havia sido feito por Mário e Oswald de Andrade.

Em consonância com o pensamento de Maria da Glória Bordini está Silviano Santiago (2005). Ele também considera Clarissa como um romance que traz inovação à Literatura Brasileira, como sendo a primeira tentativa de Erico Verissimo de dar uma estrutura musical (contraponto) ao romance, observando que, ao contrário do segundo livro (Caminhos cruzados) em que ela se realiza através da variedade de temas, em Clarissa a estrutura musical ocorre através da polifonia de vozes presentes no parágrafo.

Para Silviano Santiago, Amaro, personagem de Clarissa, músico que está empenhado em encontrar uma forma original de composição musical, a rapsódia da pensão de dona Zina que possa conter todos os sons da casa, é uma metáfora que explicita o propósito do narrador do romance também empenhado "em buscar uma forma original de composição para a sua narrativa, composição esta que pudesse apreender o que deseja apreender e no modo como o deseja." (SANTIAGO, 2005, p. 143-144), ou seja, uma forma de estrutura narrativa por meio da qual ele pudesse realizar o corte transversal da sociedade. Por essa perspectiva, Santiago conclui: 
Válida essa leitura metafórica da personagem Amaro, poderemos provar que o primeiro narrador de Erico, implicitamente, rechaça pelo menos duas concepções de estrutura romanesca que circulavam na sua época, para eleger uma terceira e original, que é a que mais convém à visão de mundo do romancista. O narrador de Erico - repetimos: implicitamente no caso de Clarissa e explicitamente no caso de Caminhos cruzados - rechaça tanto o desenvolvimento linear e evolutivo do enredo romanesco e até mesmo da composição do parágrafo dentro do romance, característica da narrativa de tipo realista-naturalista, como também rechaça a fragmentação do enredo em blocos anarquicamente dispostos, característica do romance de tipo cubista. (SANTIAGO, 2005, p. 144)

É por esse viés que Silviano Santiago vê originalidade na escrita de Clarissa, como uma narrativa em que o seu autor busca encontrar uma forma original de composição estrutural mais condizente com o propósito do seu projeto literário, diferente daquelas então usadas por seus pares. Desse modo, a aparente simplicidade de um romance que possui uma personagem central, no caso a menina Clarissa, cuja narração é realizada pela perspectiva dela, ou, conforme a terminologia de Jean Pouillon (1974, p. 54), na "visão com", ou seja, "é a partir dela que vemos os outros", esconde uma estrutura narrativa bem mais complexa. Nesse sentido, Maria da Glória Bordini (1995) lembra que as técnicas narrativas eram utilizadas pelo escritor com tamanha fluência e tanta simplicidade que os leitores nem as percebiam, e Antonio Candido (1972b), ao analisar uma palestra de Erico Verissimo, observa que o escritor, ao optar por um estilo aparentemente não-artístico, disfarçava os seus recursos narrativos, parecendo que estava escrevendo casualmente.

Esta palestra (...) ajuda a esclarecer a natureza de sua escrita. Ela se prende ao mencionado problema das relações entre arte e moral, que influi na sua opção por um estilo não-artístico, comparado por ele à roupa do homem bem vestido que não se nota. Do mesmo modo, o escritor que preferiu dar relevo à vida disfarça os seus recursos e parece estar escrevendo casualmente; e assim vemos como se chega a um certo tipo de atividade estética a partir de uma disciplina de ordem ética, para a qual Erico orientou inclusive os pendores de ironia e ceticismo que o impediram de se tornar um fanático do que quer que seja. (CANDIDO, 1972b, p.47)

Em Caminhos cruzados, romance publicado dois anos depois de Clarissa (1995b),

Erico Verissimo refina a técnica narrativa, passando a trabalhar a polifonia através da criação 
de vários temas (histórias) e não apenas dentro do parágrafo, e assim introduz a técnica do contraponto na narrativa brasileira $^{6}$ e produz uma narrativa fragmentada, sem personagens centrais, oferecendo ao Modernismo brasileiro o "romance urbano descentrado", segundo Maria da Glória Bordini:

É no seu segundo romance que Erico inaugura, para o Modernismo brasileiro, o romance urbano descentrado, solidificando-o como literatura de protesto social inequívoco. A partir de um certo comprometimento com os ideais socialistas em voga no período entre-guerras, Caminhos cruzados recusa as hierarquizações. A história não possui um núcleo temático: é formada de muitas pequenas histórias que transcorrem em diferentes bairros de classe alta, média e baixa da capital do Rio Grande dos Sul, ao sabor dos deslocamentos de seus protagonistas. O conflito se dá entre poderosos e humildes, ricos e pobres, numa análise satírica dos primeiros e compadecida dos últimos. A disposição entrecruzada das vidas de Fernanda e Noel, João Benévolo, dr. Seixas, Dodó e Leitão Leiria, d. Eudóxia e d. Maria Luisa e Zé Maria, prof. Clarimundo, Chinita e Salu, Pedrinho e Cacilda, para citar algumas, areja a trama e sustenta a leitura sem a necessidade de um fio condutor, trabalhando o suspense pelo corte de cada história em momentos nem sempre críticos, como ocorria nos folhetins. (BORDINI, 2003, p. 144)

Caminhos cruzados também foi saudado positivamente por Álvaro Lins, um dos principais críticos literários da época e, certamente, o mais severo deles em relação a obra literária de Erico Verissimo:

Neste livro, ao lado da temática do romance inglês, tão bem aproveitada e adaptada, o Sr. Erico Verissimo criava um grupo de personagens que ainda hoje permanecem ligados ao seu nome. Sentia-se que ali estava um romance pensado, sentido, construído em bases muito firmes e muito conscientes. (LINS, 1963, p.221)

Dessa forma, em Caminhos cruzados Erico Verissimo parece ter encontrado o equilíbrio entre o elemento ético, que norteia o seu projeto literário, e o elemento estético, que lhe dá os meios técnicos de realizá-lo, produzindo uma narrativa desprovida da inocência que o romance anterior possuía, ajustada ao espírito do romance social da década de 30 , conforme observa Antonio Candido, ao analisar o modo como o escritor brasileiro adaptou a técnica

\footnotetext{
${ }^{6}$ Segundo o crítico literário Silviano Santiago (2005), antes de Erico Verissimo a técnica da narrativa em contraponto tinha sido utilizada no Brasil de maneira discreta por Mário de Andrade em Macunaima.
} 
narrativa do contraponto, apropriada das literaturas de língua inglesa, de John dos Passos e Aldous Huxley, à Literatura Brasileira;

... enquanto o seu modelo imediato, Aldous Huxley (...), usou o corte horizontal para descrever a vida de um grupo restrito das classes privilegiadas da Inglaterra, Erico o democratizou de algum modo, ajustou-o ao espírito de Trinta, incorporando tanto o pobre quanto o rico e assim transformando-o de amostra em sondagem. (CANDIDO, 1972b, p. 44)

Ou seja, conforme a própria teorização de Candido (2006), Erico Verissimo ajustou a técnica emprestada às necessidades e características da Literatura Brasileira da década de 30, bem como aos objetivos de seu projeto literário de realizar um corte transversal da sociedade. Ou ainda, como pensa o teórico russo Victor Zhirmunski (1994), houve a transformação social do modelo adotado, através de um processo de reinterpretação e adaptação da técnica apropriada às condições literárias brasileiras da época.

Quanto à escolha da técnica do contraponto, Maria da Glória Bordini (1985) afirma que ela não foi feita com intenções imitativas e sim por uma necessidade estrutural estreitamente ligada não só ao projeto literário do escritor como também ao projeto de democratização da literatura que ele desenvolvia frente à Editora Globo na época da escrita do romance:

Verissimo recorre a ele (o contraponto) por uma necessidade estrutural e não por intento imitativo. É apenas através desse artifício que poderia atingir a legibilidade responsável pelo êxito junto às massas sem prejudicar o sentido coletivo do entretecimento de tantos destinos numa só tela: a da cidade em que todos se juntam e paradoxalmente se isolam. Poderia, ao invés do contraponto, ter empregado a técnica do mosaico, mas perderia a dimensão temporal, a continuidade das vidas simultâneas e as possibilidades de ironia criadas pelos momentos coincidentes de existência individuais. Poderia ter se valido da justaposição por metonímia, como faz Virginia Woolf em $O$ quarto de Jacob, mas isso impediria a leitura não sofisticada e é certo que Verissimo se propunha à democratização da literatura, como bem comprova sua atuação à frente da Editora Globo nas décadas de 30 e 40.

O que importa é que, manejando destramente técnicas narrativas pouco conhecidas no Brasil daquela época, soube criar, para qualquer leitor, uma bela metáfora da sociedade urbana, a aplicável não só a Porto Alegre de então, mas à ideia de cidade que ainda prevalece junto ao público: um lugar onde a ação pessoal de nada vale, porque a metrópole, ao mesmo tempo que 
os promove, torna anônimos todos os presumíveis heróis e nivela todos os dramas individuais, banalizando o livre arbítrio e reduzindo-os à paródia de si mesmo, contra a massa de interesses em choque, manipulados por forças que parecem situar-se para além do entendimento comum. (BORDINI, 1985, p. 32-33)

Dessa forma, Erico Verissimo, através da técnica do contraponto, que lhe permite usar processos narrativos cinematográficos e narrar ações simultâneas, e valendo-se de um narrador onisciente que possui uma visão privilegiada dos acontecimentos internos e externos de suas personagens, consegue realizar o corte transversal da sociedade retratada no romance, pois o narrador passeia com seu olhar observador por todos os estratos sociais da cidade, desnudando ao leitor a hipocrisia de alguns setores da classe burguesa, bem como a luta pela sobrevivência das classes baixas, contra a o desemprego, a fome e a doença.

Assim, através do corte transversal dessa sociedade realizado pelo narrador, o leitor acompanha num período restrito de tempo, apenas cinco dias (de sábado a quarta-feira), as ações e os pensamentos privados do casal Leiria, quase sempre incompatíveis com a sua imagem pública; o estilo de vida mantido pelas aparências e regido pelo interesse social e econômico das classes mais altas (as relações entre a família Pedrosa e Leiria); o conflito de classes (João Benévolo e Fernanda são demitidos por Leitão Leiria); a luta diária de Fernanda para sustentar a família; o desespero de Laurentina diante falta de atitude do marido e da investida de Ponciano; a miséria de Maximiliano e sua família, aguardando a morte sem ver nenhuma perspectiva de futuro; a alienação do professor Clarimundo e Noel, os dois intelectuais e candidatos a romancista que não conseguem perceber a vida que se desenvolve na frente de seus olhos; e a desintegração de uma família (Pedrosa) provocada pelas tentações e facilidades que a riqueza traz. Ou seja, através desse corte transversal, possibilitado pelo uso hábil da técnica narrativa do contraponto, "o mundo oferecido pelo romancista”, para utilizar uma expressão utilizada por Fábio Lucas (1972), abrange todos os segmentos sociais, 
dissecando-os e oferecendo-os ao leitor, em total consonância com a estética modernista do romance de 30, à qual Erico Verissimo se filia.

Para a escrita de Caminhos cruzados, além da técnica do contraponto, Erico Verissimo se valeu também da metaficção, através da introdução de duas personagens-escritores que refletem sobre o fazer literário no decorrer da narrativa: o professor Clarimundo e Noel. Sobre a metaficção, é necessário lembrar que esse recurso narrativo se faz presente na obra do escritor desde o seu primeiro livro publicado (Fantoches) e se tornaria, ao lado do contraponto, num elemento constante em toda a obra do escritor, conforme observa o professor Flávio Loureiro Chaves:

Ao longo da sua obra, Erico Verissimo sempre manteve presente a problematização do ato da escritura, discutindo o texto que apresenta ao leitor. O debate sobre a função e a finalidade da literatura é uma questão vital para várias personagens, um tema itinerante e, assim, um núcleo da ficção. Desde os romances iniciais até o "diário" de Martim Francisco Terra, no Incidente Antares, passando por algumas personagens que funcionam como "alter-ego", a figura do escritor é incluída na própria história narrada, propondo o tema do "livro dentro do livro". (CHAVES, 2001, p. 155).

Dessa forma, esses dois recursos narrativos, o contraponto e a metaficção, que foram utilizados juntos pela primeira vez em Caminhos cruzados, estariam presentes nas melhores criações literárias de Erico Verissimo, aliadas a outras técnicas narrativas que o escritor foi desenvolvendo e incorporando ao seu projeto literário.

No entanto, depois da publicação de Caminhos cruzados a obra literária do escritor sofreu uma turbulência em relação à crítica literária. Muitos críticos identificaram uma queda de qualidade em seus romances posteriores; qualidade que para eles só foi recuperada por Erico Verissimo com a publicação de O resto é silêncio (19951), em 1943, e, principalmente, com a trilogia O tempo e o vento, produzida entre 1949 e 1962. Álvaro Lins (1963), um dos mais renomados críticos literários da época, julgou que o romancista gaúcho a partir da 
plenitude alcançada com Caminhos cruzados começou a piorar de romance para romance, realizando um percurso descendente em relação à qualidade literária.

Contrariamente ao baixo prestígio crítico, Erico Verissimo se tornou, no mesmo período, um dos escritores mais populares do país, um sucesso editorial só comparado a seu contemporâneo Jorge Amado. Os mesmos romances, Música ao longe, Um lugar ao sol, Olhai os lírios do campo e Saga, que sofriam severas reservas de uma parte da crítica especializada eram aclamados pelo público leitor. Esse sucesso público do romancista piorou a sua imagem perante os seus críticos, pois eles viam esse fato como a confirmação da falta de qualidade do escritor, conforme nos aponta Wilson Martins (1977, p. 293) ao observar que "os críticos brasileiros dos anos 30 decidiram tacitamente que o sucesso editorial do romancista era a prova da sua falta de qualidade" (MARTINS, 1977, p. 293).

Dessa forma, o fato de ser um escritor popular, cujos romances eram sinônimos de sucesso de vendagem, tornou-se uma faca de dois gumes: por um lado, proporcionava a Erico Verissimo o reconhecimento de público, que é algo que todo escritor almeja, e, consequentemente, dava a ele a possibilidade de poder viver fazendo aquilo que gostava, e, por outro lado, esse sucesso levava parte da crítica a considerar que a baixa qualidade de seus romances é que era a responsável pelo êxito de público, chegando ao ponto de Álvaro Lins (1963) acusá-lo de fabricar livros para o sucesso. Para esse crítico não havia dúvida alguma que o sucesso público estava influenciando negativamente o romancista, conforme podemos observar no trecho abaixo:

Sendo certo, porém, que o Sr. Erico Verissimo possui as qualidades do romancista, a consciência do seu ofício, o senso da literatura - vale a pena acentuar que deve haver uma circunstância acidental perturbando a construção da sua obra. Esta circunstância estou certo que não errarei afirmando que é o sucesso público. Quero esclarecer, no entanto, que não estou animado de nenhuma prevenção contra este nome doce ou contra o acontecimento sedutor que ele exprime. Sucesso nem sempre significa concessão, mediania, vulgaridade. Creio mesmo que amar o sucesso e desejá-lo - quero dizer: compreensão e aplauso é uma espécie de sentimento geral de todo artista e todo escritor. ( ...) Mas o sucesso atuou no senhor Sr. 
Erico Verissimo como uma espécie de vertigem. O público empolgou-o. Apresenta hoje, por isso, o espetáculo de um autor que os leitores dominam. Não é mais o romancista que faz a sua arte, como em Caminhos cruzados; é o público que lhe impõe o seu gosto e suas preferências. (LINS, 1963, p. 222)

Desse modo, Álvaro Lins qualifica Erico Verissimo como um escritor que depois de experimentar o gosto do sucesso público torna-se escravo dele, a ponto de as preferências dos leitores guiarem o conteúdo de seus livros, fazendo com que o romancista piorasse de livro para livro. O juízo crítico de Lins foi decisivo para que o nome de Erico Verissimo fosse lançado numa espécie de limbo, sendo considerado por muito tempo como um escritor menor no panorama do Modernismo brasileiro. Nesse sentido, a professora Maria da Glória Bordini (1995, p. 15-16) observa que "o prestígio intelectual do crítico impregnou muita avaliação oral ou apressadamente impressa, sendo necessárias várias décadas (...) para que a obra de Verissimo fosse apreciada estética e sociologicamente à altura de seu desempenho". O silêncio da crítica literária, gerado em torno do nome do escritor, só foi quebrado em 1972, quando o professor Flávio Loureiro Chaves publicou $O$ contador de histórias, a primeira obra crítica sobre a literatura de Erico Verissimo, reunindo ensaios de Otto Maria Carpeaux, Antonio Candido, Guilhermino Cesar, Tristão de Atahyde, Moysés Vellinho, Gilberto Mendonça Telles, Fábio Lucas, Donaldo Schüler, Regina Zilberman, Jean Roche e do próprio organizador.

No entanto, a obra do escritor gaúcho não foi somente alvo de apreciações negativas por parte da crítica especializada nas décadas de 30 e 40. Ela também mereceu apreciações positivas, como, por exemplo, a de Antonio Candido que, em oposição ao pensamento de Álvaro Lins, e sem deixar de reconhecer as fragilidades da obra de Erico Verissimo, fez uma defesa do escritor contra a crítica desfavorável que circulava nos meios acadêmicos e entre o público mais exigente. Afirma Candido, num ensaio publicado no começo dos anos 40: 
É claro que Erico Verissimo não é um romancista extraordinário: é claro que não traz nenhuma mensagem excepcional no domínio da arte, nem se salienta pela originalidade superior da sua criação. Não obstante, é também claro que é um romancista de primeira ordem, um escritor que tem vocação firme e que vem representando na nossa literatura contemporânea o aspecto "romance de costumes", em que ela é tão pobre, escrevendo livros, uns de grande beleza, outros fracos, nos quais está presente um sentimento muito humano da arte. Por isto, a atitude de condenação que alguns dos nossos meios cultos têm assumido diante dele é injusta e pouco clarividente.

(...)

Para julgá-lo, é preciso, antes de mais nada, reconhecer que há nele uma vocação inequívoca de escritor. É um verdadeiro romancista, um homem que nasceu para isto. (CANDIDO, 2004a, p. 63-64-69)

A diferença entre o juízo crítico de Antonio Candido e o de Álvaro Lins é que para este, antes de $O$ resto é silêncio, apenas Caminhos cruzados se salvava na produção literária do escritor gaúcho, enquanto aquele considerava Clarissa, Música ao longe e Um lugar ao sol como bons romances, embora não tivessem a qualidade de Caminhos cruzados. Candido só condenou como má literatura os romances Olhai os lírios do campo (1995n) (em menor grau) e Saga, conforme podemos observar no comentário abaixo:

Dentro da segunda orientação (romance tipo americano), que é sem dúvida a de Erico Verissimo, cabem também as obras de largo sentido humano e popular - categoria em que se ordenam as do escritor gaúcho. Daí sua eficiência e o seu caráter social. Daí, também, muitos dos perigos que ele nem sempre soube evitar, e que o conduziram a escrever um livro inferior, um livro de qualidade mais do que duvidosa, mais do que comprometedora, que os seus admiradores quereriam poder esquecer: Saga. Este livro e Olhai os lírios do campo, em menor grau, representam uma queda na produção do autor. A abundância palavrosa, o sentimentalismo social, a declaração humanitária, a esquematização psicológica, as fraquezas de uma cultura geral que não observa a devida modéstia - fazem delas obras de valor bem secundário. O que não impede que atrás exista uma série, de Clarissa a Um lugar ao sol, digna de conservar o alto posto que o autor deve ter nas nossas letras. (CANDIDO, 2004a, p.67)

No mesmo texto, Antonio Candido (Ibid.) observa que a constante preocupação com os problemas das classes sociais faz com que haja nos romances de Erico Verisismo a predominância da amplitude social sobre a profundidade psicológica e do panorama coletivo sobre o destino individual, sendo que é esta característica da ficção do escritor que faz com que o crítico o classifique como um romancista de costumes, que privilegia em suas obras 
literárias a análise no comportamento das personagens em relação ao meio, e desse modo o romancista dá aos seus romances uma amplitude social inexistente entre os seus contemporâneos.

O primeiro romance de Erico Verissimo a ser recebido com certa reserva pela crítica literária foi Música ao longe (1995e), publicado no mesmo ano (1935) da publicação de Caminhos cruzados $^{7}$ e isso certamente colaborou para a comparação qualitativa entre os dois, com o apontamento da inferioridade do primeiro em relação ao segundo romance. No entanto, os defeitos apontados pela crítica literária após a sua publicação, reconhecidos inclusive pelo próprio autor, não impediram que no ano anterior Música ao longe fosse agraciado com o Prêmio Machado de Assis, juntamente com Os ratos de Dyonélio Machado, Marafa, de Marques Rebello, e Totônio Pacheco de João Alfonsus.

Nesse romance, Erico Verissimo põe em cena novamente a menina Clarissa, do romance homônimo, agora já uma moça e de volta à sua cidade natal, Jacarecanga, onde trabalha como professora numa escola municipal. Mas o ambiente à volta da personagem não é mais aquele de inocência e sonho, de quando vivia na casa da tia Zina em Porto Alegre, e sim de decadência, pois a sua família, legítima família representante do patriarcado gaúcho, está prestes a perder tudo. Junto com os pais e tios de Clarissa, aparece também pela primeira o primo Vasco Bruno, personagem que irá compor com ela, e Fernanda e Noel, de Caminhos cruzados, os romances Um lugar ao sol e Saga.

Para o próprio Erico Verissimo, num prefácio escrito em 1961 para a reedição do romance, o principal defeito do livro estava no fato de ele não ter dado um tratamento sério e de profundidade à história de decadência dos Albuquerques, deixando que a queda moral e

\footnotetext{
${ }^{7}$ Maria da Glória Bordini (2003) refere-se a Caminhos cruzados como o segundo romance publicado por Erico Verissimo. No entanto, Flávio Loureiro Chaves (2001) aponta que esse romance foi publicado logo em seguida a Música ao longe. Quanto ao período de escrita, pelo fato de Música ao longe ter sido escrito em 15 ou 20 dias do ano anterior (1934) para concorrer ao Prêmio Machado de Assis da Companhia Editora Nacional, parece-nos que ele é anterior a Caminhos cruzados.
} 
econômica do clã fosse visto pela ótica de Clarissa, uma adolescente de dezesseis, ainda imatura para compreender e avaliar a extensão e a profundidade do drama que sua família estava vivendo. Ao fazer essa reflexão, quase trinta anos depois, o escritor se questiona também: será que o autor possuía essa maturidade que a menina não tinha? A pergunta fica sem resposta, mas deixa entrever um "provavelmente não".

No entanto, Música ao longe apresenta algumas novidades formais e de conteúdo que seriam importantes para o desenvolvimento do projeto literário do escritor. No plano formal, pela primeira vez Erico Verissimo utiliza dois narradores num romance, intercalando a narração em terceira pessoa com uma narração em primeira pessoa, através da inserção do diário de Clarissa na narrativa. Esse recurso narrativo, como sabemos, seria retomado posteriormente na elaboração da trilogia O tempo e o vento, através dos capítulos "Caderno de pauta simples" e "Do diário de Sílvia", e também em Incidente em Antares (1995d), no diário de Martim Francisco Terra.

No plano do conteúdo, aparece de forma explícita a crítica à guerra e a todo tipo de violência física contra o ser humano, que será uma preocupação constante na obra do escritor. Vejamos um trecho em que Clarissa fica horrorizada ao ouvir as histórias familiares nas quais a guerra e seus horrores estão sempre presentes e essa descoberta a faz refletir sobre o porquê de tanta violência:

Viveram felizes muitos anos, mas rebentou a revolução de 93 e numa tarde muito bonita o marido da tia Zezé apareceu degolado à beira dum capão.

Sempre que houve este detalhe da história, Clarissa sente um calafrio. Degolado! Não pode compreender como possa existir gente que sinta o prazer em passar a faca na garganta do próximo. $\mathrm{E}$ as proezas que nos serões de sua casa se contam de revoluções e guerras estão cheias de degolamentos. Às vezes aparecem de visita senhores graves, de cabelos brancos, com caras carrancudas ou sorridentes, falando como toda gente, respeitados por todos. Chegam, conversam, tomam licor ou café, fumam, riem, contam casos e saem. E, quando a porta se fecha, atrás deles, tia Zezé cochicha de seu canto: - Esse é um grande bandidão de marca maior. Um dia em 93 mandou degolar cinco homens na fazenda do Jacó Alemão.

E faz-se um silêncio fundo em que todos veem mentalmente cinco homens de gargantas rasgadas.

E João de Deus, olhando para a tia Zezé com ar de repreensão diz: 
- Sim, titia, mas ele é um macho! No combate da Praça do Conde terçou armas com dois federalistas e derrubou os dois. Que ele é macho é mesmo! (VERISSIMO, 1995e, p. 55).

A denúncia da guerra e da violência, que a partir de então seria um elemento constante na obra literária de Erico Veríssimo, quase sempre é feita por uma voz feminina (Clarissa, Fernanda, Ana Terra, Bibiana, Maria Valéria) ou pela voz masculina de um intelectual (Vasco Bruno, Floriano Cambará, Pablo Ortega e Martin Francisco Terra).

O livro seguinte, Um lugar ao sol, publicado em 1936, é uma mescla dos romances anteriores de Erico Verissimo, tanto na forma quanto no conteúdo. Nesse romance, que Antonio Candido (2001) considerou meio banal, mas que agradou ao crítico pela visão ficcional de Porto Alegre, o escritor, como se estivesse tecendo uma colcha de retalhos, reúne personagens de seus livros anteriores: Clarissa, Amaro, D. Zina e Tio Couto, de Clarissa; D. Clemência e Vasco de Música ao longe; Fernanda, Noel. D. Eudóxia e Pedrinho de Caminhos cruzados; aos quais acrescenta o Rev. Bell, o conde Oskar, Olívio, Annelise, D. Magnólia, Orozimbo, Lu, Delicardense, Álvaro Bruno, Gervásio e o Dr. Seixas, que também figurará em Olhai os lírios do campo.

O principal espaço ficcional é a cidade de Porto Alegre, lugar onde foram ambientados também Clarissa e Caminhos cruzados. Na primeira parte do romance, ainda ambientada em Jacarecanga, consuma-se o processo de decadência da família Albuquerque, abordado em Música ao longe, com a morte do patriarca João de Deus e a perda do casarão onde a família vivia, acontecimentos que vão levar Clarissa, a mãe e Vasco para Porto Alegre em busca de uma nova vida. Lembramos que o processo de decadência do patriarcado gaúcho e ascensão social e econômica dos imigrantes italianos e alemães seria retomado pelo autor em $O$ resto é silêncio e principalmente na trilogia $O$ tempo e o vento.

Quanto à forma narrativa, Erico Verissimo utiliza em alguns pontos do romance a técnica do contraponto anteriormente utilizada em Caminhos cruzados, alternando-a com a 
narrativa em forma tradicional, ao mesmo tempo que também alterna a forma de visão dos fatos narrados, ora utilizando a "visão com”, que na teorização de Jean Pouillon (1974, p. 54) é a partir da visão de uma determinada personagem que nós vemos as outras personagens e os acontecimentos narrados, ora utilizando a "visão por trás", na qual o narrador possui onisciência total sobre o espaço, as personagens e suas ações.

Outro recurso narrativo que o autor volta a lançar mão neste romance é a metaficção, através do retorno da personagem-escritor Noel, que em Caminhos cruzados planeja e inicia a escrita de um livro, que será finalizado e publicado no final de Um lugar ao sol. Dessa forma, retornam as reflexões sobre o fazer literário, sempre tocando no ponto nevrálgico da discussão literária da década de 30: a dicotomia entre arte e realismo.

Depois de Um lugar ao sol vieram Olhai os lírios do campo, publicado em 1938, e Saga, publicado em 1940, os dois romances que mais receberam avaliações negativas da crítica literária e são considerados os piores romances escritos por Erico Verissimo, inclusive pelo próprio autor, que os considera romances medíocres.

Em relação a Olhai os lírios do campo, apesar dos muitos defeitos que possui, o romance apresenta um aspecto positivo: a estrutura narrativa da primeira parte da obra, fato que foi reconhecido até por Álvaro Lins (1963). Nessa primeira parte, que ocupa a metade do livro, Eugênio, o protagonista do romance, está indo de carro de uma estância no interior do estado a Porto Alegre, onde sua antiga namorada Olívia está às portas da morte. Durante essa viagem angustiante e desesperada, a memória da personagem vai reconstituindo os acontecimentos passados, desde a infância de Eugênio até bem próximo da ação presente, até que eles expliquem completamente o drama vivido por ele. Antonio Candido (1972a) acertadamente viu a utilização desse recurso narrativo como a primeira tentativa de Erico Verissimo de combinar dois eixos temporais numa narrativa, técnica que seria fundamental na elaboração de $O$ tempo e o vento. 
Dessa forma, mesmo sendo um romance ruim, a composição formal da sua primeira parte é inovadora e surpreendente, apresentando uma "estrutura narrativa centrada em tal jogo milimétrico de avanços e recuos temporais, que ainda hoje nos causa admiração", conforme observa Sergius Gonzaga (1990, p. 39). Na segunda parte, que ocupa a outra metade do livro, a narrativa não possui o aprimoramento técnico da primeira, e é onde se afloram o excesso de sentimentalismo e a filosofia salvacionista barata observada pelo próprio autor.

Quanto à Saga, o livro de Erico Verissimo que mais desagradou a crítica literária brasileira e que foi praticamente renegado posteriormente pelo escritor, o romance é dividido em quatro capítulos: nos dois primeiros, "O círculo de giz" e "Sórdido interlúdio", Vasco está na Espanha lutando contras as forças fascistas na sangrenta Guerra Civil Espanhola; no terceiro, "O destino bate à porta", ele está de volta a Porto Alegre, onde junta-se à Clarissa, Noel, Fernanda e Eugênio; e no último capítulo, "Pastoral", Vasco e Clarissa, então casados, estabelecem-se como agricultores no vale de Águas Claras. A novidade formal deste romance é que pela primeira e única vez Erico Verissimo utiliza um narrador em primeira pessoa no decorrer de toda a narrativa.

Saga, conforme já indicamos, recebeu uma infinidade de críticas e é considerado pela grande maioria da crítica literária, o pior romance de Erico Verissimo, embora a obra tenha recebido uma avaliação positiva por parte de Massaud Moisés e Tristão de Athayde que, na contramão de todos, consideraram-no "uma das obras mais bem construídas da fase inicial de sua carreira" (MOISÉS, 2009, p.181) e "um de seus melhores romances" (ATHAYDE, 1972, p. 91).

A sentença crítica final do livro coube a Álvaro Lins (1963), que julgou que o romance pouco ou nada possuía de literário, ao mesmo tempo em que apresentava artificialismo e vulgaridade na construção de algumas personagens e situações, e ainda um excesso de 
reflexões moralistas sobre a guerra e os sentimentos humanos. Assim o crítico conclui o seu ensaio sobre a obra:

Saga não se salva nem pelos personagens, nem pela ação, nem pelo ambiente. Nem mesmo pelo estilo literário, um elemento duvidoso e irregular em toda a obra do Sr. Erico Verissimo; ou pela composição técnica do romance, como sucedeu com a primeira parte de Olhai os lírios do campo. Dir-se-á talvez que Saga poderá salvar-se pelo que representa como documento humano, quer dizer: como expressão de sentimentos de paz, de fraternidade, de solidariedade humana. Concordo que estes sentimentos são realmente puros e nobres. Concordo que esta obra seja benéfica sob este ponto de vista, mas não creio que caiba propriamente ao romance este papel edificante e prático. O destino da convicção ideológica e sentimental pertence à oratória e não à obra de arte. Ao romance, não, portanto. (LINS, 1963, p. 224)

A nosso ver, Saga foi uma tentativa do romancista de levar o seu engajamento ético ao extremo, respondendo ao chamado histórico daquele sombrio período às vésperas da Segunda Guerra Mundial, engajando radicalmente a sua literatura na frente progressista anti-fascista. $\mathrm{O}$ grande problema foi que a radicalidade estética não acompanhou a radicalidade ética do romance, ficando a obra restrita apenas às boas intenções de solidariedade humana.

No entanto, entendemos que Saga, apesar de ter sido o pior romance do escritor, ocupa um papel importante no processo de desenvolvimento do projeto literário de Erico Verissimo, pois a má recepção da obra, por parte da crítica literária, desencadeou uma espécie de crise intelectual no escritor, levando-o a refletir seriamente sobre os rumos da sua ficção. Nesse sentido, a crítica feroz feita por Álvaro Lins no mesmo ano da publicação do romance talvez tenha sido de utilidade para o romancista. Lins, na época, afirmou que a obra colocava o autor numa encruzilhada: "situado entre dois caminhos para escolher definitivamente: ou uma mudança completa e violenta de rumo ou a colocação fora da literatura como um Eugênio Sue qualquer" (LINS, 1963, p. 221).

Antes de prosseguirmos, é necessário lembrar também a justificativa que Erico Verissimo deu a seus erros de composição e às fragilidades de seus primeiros romances. 
Numa entrevista concedida ao Jornal Opinião, em 1973, e republicada por Maria da Glória Bordini em A liberdade de escrever: entrevistas sobre literatura e política (1997), o autor afirma:

É preciso saber que as condições econômicas de minha vida pessoal, particular, influenciaram muito os romances que escrevi entre 1933 e 1940. Observe-se como meus personagens dos livros dessa época preocupavam-se com as contas a pagar no fim do mês. Eu trabalhava longa e duramente mais de 12 horas por dia. Traduzia livros de várias línguas para o português (mais de 40), inventava histórias para programas de rádio para a infância, armava páginas femininas para o Correio do Povo, tudo isso enquanto trabalhava na revista e na editora da Livraria do Globo. Isso explica a pressa com que escrevi meus próprios romances naquela década de 30. Considero essa fase de minha carreira um período de exercícios em que me preparei - consciente ou inconsciente - para a obra que comecei a sonhar depois de 1935 e que acabou sendo publicada a partir de 1949 sob o título geral de $O$ tempo e $o$ vento. Depois de Olhai os lírios do campo, romance cheio de defeitos, mas com grande carga emocional, comecei a ganhar royalties que melhoraram minha situação econômica. Pude trabalhar mais devagar e tive mais tempo para ler... e para me ver e julgar. (VERISSIMO apud. BORDINI, 1997, p. 125-126)

Dessa forma, entendemos que a melhora da situação econômica do escritor, que lhe possibilitou mais tempo para a leitura, escrita e reflexão, aliada à experiência frustrada da escrita de Saga e ao desconforto sentido pelo autor após a sua publicação, levaram Erico Verissimo à procura de uma melhora qualitativa para a sua obra literária, desencadeando o processo que conduziria o escritor à elaboração de $O$ tempo e o vento. Nesse sentido, em relação à malograda experiência de Saga, Wilson Martins observa:

No fundo importa pouco que um excelente romancista haja escrito, em um momento ou outro de sua vida, um livro inferior; o que importa é verificar por que o fez. (...) Nenhuma experiência é inútil e essa teve, entre outras, a vantagem de desencadear sutilmente o processo psicológico de que resultaria, dez anos depois, O tempo e o vento. (MARTINS, 1968)

O primeiro resultado positivo da maior disponibilidade do autor para a escrita e do aprendizado com os erros de Saga foi a publicação, três anos depois, de $O$ resto é silêncio, romance considerado por Wilson Martins (1977), e também por grande parte da crítica literária brasileira, como um divisor de águas na carreira do escritor, opinião também 
compartilhada, ao que parece, pelo próprio autor que, no prefácio para a reedição do livro em 1953, assim se manifestou sobre o romance:

$O$ resto é silêncio talvez seja o princípio duma nova fase na carreira literária do autor, o qual, desse livro para diante, passou a trabalhar a forma com maior cuidado, procurando evitar as facilidades e simplificações que haviam tornado tão frouxo $\mathrm{e}$ desigual $\mathrm{o}$ estilo dos romances anteriores. (VERISSIMO, 1995i, p. 11-12)

Nessa obra, Erico Verissimo retoma a técnica do contraponto habilmente utilizada em Caminhos cruzados e em menor escala em Um lugar ao sol, e utiliza também um artifício como mote da narrativa: o suicídio de uma jovem no centro de Porto Alegre é visto por sete personagens, e através do contraponto o narrador vai mostrando como essas sete pessoas viram a queda da garota.

A partir desse fio condutor, o narrador vai apresentando essas sete personagens, juntamente com outras pertencentes aos seus círculos familiares e sociais, ao mesmo tempo em que vai reconstituindo a vida delas, através da utilização de analepses. Sobre o narrador desse romance, forte e onisciente como o de Caminhos cruzados, Gilberto de Mendonça Telles (1979, p. 321) observa que "trata-se de uma dessas narrativas em que o narrador se apresenta maior que as personagens, conhecendo-lhes toda a trajetória e os mais íntimos pensamentos", ou seja, o narrador possui uma "visão por trás", conforme a teoria de Jean Pouillon (1974).

Pelo fato da ação se passar num período de pouco mais de 24 horas, Álvaro Lins (1963) viu nessa escolha uma apropriação da técnica utilizada por James Joyce para a escrita de Ulisses, recurso que o crítico considerou como um fator positivo, assim como a retomada da técnica do contraponto. Lins exalta também a capacidade que o escritor tem de compor um romance, considerando que a arte da composição, a utilização das técnicas narrativas, é a principal qualidade dos seus livros, e reconhece, com certa satisfação, que $O$ resto é silêncio é 
muito superior aos dois romances publicados anteriormente por Erico Verissimo, Olhai os lírios do campo e Saga.

No entanto, ele também tece algumas críticas ao romance, considerando-o inferior a Caminhos cruzados. Dentre os defeitos apontados por Álvaro Lins estão os objetivos excessivamente sentimentais e humanos; o excesso de otimismo que a narrativa apresenta, sobretudo através da personagem Tônio Santiago, que muitas vezes perde-se em devaneios; e a preocupação maior com as situações sociais em detrimento das personagens, criando, assim, personagens tipos-sociais, sem profundidade psicológica, extremamente previsíveis, planas, conforme a classificação de E. M. Forster (2008), à exceção de Marina Rezende e do empresário Norival Petra, que ele considera como boas criações. Ao final de sua análise, Lins afirma que o romance é "um livro que bem documenta, sob vários sentidos, o talento de romancista do Sr. Erico Verissimo" (Ibid., p. 228), e que a crítica rigorosa que ele faz da obra do escritor é porque se espera muito mais do seu talento de romancista.

Antonio Candido (2004a) também saudou positivamente $O$ resto é silêncio, afirmando que através dessa obra Erico Verissimo recupera o bom nível literário dos romances anteriores a Olhai os lírios do campo e Saga, e essa retomada da qualidade traz de volta à obra do escritor a confiança abalada pelos livros ruins. Dentre os aspectos positivos do romance, apontados por ele, estão as personagens. Ao contrário do que pensa Álvaro Lins, Candido considera que quase todas elas são bem construídas, com destaque para o desembargador Lustosa, em cuja criação "Erico Verissimo atingiu a perfeição técnica do monólogo interior misturado às observações do romancista, num entrosamento de planos de grande efeito" (Ibid, p. 71) e o velho caudilho Quim Barreiro, que considera uma das figuras mais vivas do romance. Embora o crítico perceba que haja partes do livro, principalmente aquelas relacionadas ao escritor Tônio Santiago, em que aparece a mão do autor arranjando demais as 
coisas, ele afirma que isso não chega a prejudicar a "impressão de verdade que se desprende do livro" que por sua vez "garante a sua eficiência como obra de arte".

Para Antonio Candido, o resultado final desse livro panorâmico em que predomina a narração em detrimento da observação psicológica, e as atenções são voltadas para as personagens vistas em conjunto, em plena interação social, é que Erico Verissimo constrói "um pequeno mundo todo seu, formado por dezenas de personagens vivas, agindo, participando da vida e dando aos seus livros uma amplitude social que não existe em nenhum outro romancista" brasileiro (CANDIDO, 2004a, p. 71).

Dessa forma, embora não haja uma unanimidade crítica em relação ao livro, havendo, inclusive, divergências contrastantes, como os diferentes juízos de Álvaro Lins e Antonio Candido sobre a construção das personagens, o que parece não haver dúvida é que com esse romance Erico Verissimo volta a trabalhar com equilíbrio o elemento ético e o estético, harmonia que é fundamental na concepção do seu projeto literário de realizar um corte transversal da sociedade.

Ainda que o escritor não tenha conseguido alcançar o mesmo nível estético de Caminhos cruzados, ao retomar a qualidade literária desse romance, Erico Verissimo desfaz a turbulência pela qual passou o seu projeto literário, reconquista o crédito junto à crítica e, principalmente, ganha fôlego para escrever aquela que é considerada a sua obra-prima, a trilogia $O$ tempo e o vento, em que ele atinge o ponto máximo de seu projeto literário, ao realizar um corte transversal da sociedade, conciliando alta elaboração estética com literatura de intervenção social.

Nesse sentido, é tão evidente o papel que $O$ resto é silêncio ocupa na obra do escritor, como elemento desencadeador de uma nova fase literária, que há uma espécie de trailer de $O$ tempo e o vento no final do romance, através das reflexões da personagem Tônio Santiago, conforme o próprio autor reconhece no prefácio escrito dez anos depois para a reedição do 
livro. Ao ouvir a execução da Quinta Sinfonia de Beethoven, Tônio Santiago põe-se a pensar nos antepassados das pessoas presentes no Teatro São Pedro:

Quando o tema da Sinfonia ${ }^{\circ} 5$ preocupava o espírito do compositor, os antepassados da maioria das pessoas que enchiam o teatro andavam pelas campinas do Rio Grande do Sul a guerrear os espanhóis na disputa das Missões.

(...)

No princípio eram as coxilhas e planícies desoladas, por onde os índios vagueavam nas suas guerras e lidas. Depois vinham os primeiros missionários; mais tarde, os bandeirantes e muitos anos depois os açorianos. Sob o claro céu do sul processara-se a mistura de raças. Travaram-se lutas. Fundaram-se estâncias e aldeamentos. Ergueram-se igrejas. Surgiram os primeiros mártires, os primeiros heróis, os primeiros santos...

Passeando o olhar pelo teatro, Tônio pensava na distância que ia do primitivo "Presídio do Rio Grande" àquele exato momento em que remotos descendentes de índios, portugueses, paulistas e espanhóis escutavam o allegro da Quinta Sinfonia.

(...)

A essas reflexões o espírito de Tônio se enchia de quadros e cenas, vultos e clamores. Ele via o primeiro trigal e a primeira charqueada. Pensava na solidão das fazendas e ranchos perdidos nos escampados, nas mulheres de olhos tristes a esperar os maridos que tinham ido para a guerra ou para a áspera faina do campo. Imaginava os invernos de minuano, as madrugadas de geada, as soalheiras do verão e a glória das primaveras. As lendas que vão surgindo nos matos, nas canhadas nos socavões da serra, nos aldeamentos dos índios e nas missões. As povoações novas que surgiam e as antigas que cresciam, transformando em cidades. (VERISSIMO, 1995i, p. 401-402)

Pois não é outro senão o projeto de escrita de $O$ tempo e o vento, um empreendimento que levou 13 anos para ser concretizado. Constituída pelos romances $O$ continente, $O$ retrato e $O$ arquipélago, publicados respectivamente em 1949, 1951 e 1962, a trilogia narra a saga da família Terra-Cambará num período de 200 anos (1745-1945), mesclada à história política e social do estado do Rio Grande do Sul e do Brasil. Para elaborá-la, o escritor se valeu do amadurecimento das técnicas narrativas utilizadas por ele nos romances anteriores, tais como o contraponto, a polifonia, os jogos com o tempo e a metaficção.

Esta obra monumental e de estrutura complexa é considerada como o ponto máximo da literatura de Erico Verissimo, onde o escritor conseguiu encontrar o almejado equilíbrio entre alta elaboração estética com literatura de intervenção social. Para Álvaro Lins (1963), com esse romance Erico Verissimo confirmou aquilo que ele esperava do escritor; e para 
Antonio Candido (2001), na trilogia o romancista alcançou o seu auge, após uma carreira cheia de oscilações:

Quando chegamos a $O$ tempo e o vento sentimos que Erico finalmente alcançou a sua melhor forma, ao longo de uma carreira marcada por altos e baixos. O primeiro volume da série, $O$ continente, é um dos grandes romances da literatura brasileira. Ele nos faz compreender, inclusive, que as fraquezas de alguns livros anteriores, e mesmo dos outros dois volumes da série, correspondem em parte a uma espécie de generosidade de sua natureza de escritor. (VERISSIMO, 2001, p. 15)

Alfredo Bosi, que tem uma postura um pouco semelhante à de Álvaro Lins sobre Erico Verissimo, reconhece que com $O$ tempo $e$ o vento o escritor demonstra "suas reais possibilidades criadoras" (BOSI, 2004, p. 408), entretanto, não muda o seu conceito sobre o escritor, considerando-o, ainda, um autor mediano que oscila entre o intimismo e a crônica de costumes, característica que faz com que seus romances sejam de "tensão mínima" na visão do crítico. Já para Massaud Moisés (2009, p. 182-183), com O tempo e o vento Erico Verissimo "encontrava a sua maneira mais funda de ser, como homem e profissional das letras", colocando a estrutura da obra a serviço do seu povo. De acordo com o crítico, nessa narrativa o escritor soltou a fantasia na direção do passado gaúcho como se sondasse a si mesmo em busca de uma identidade oculta, incitando o leitor a aderir com a sua imaginação aos quadros ficcionais e históricos pintados por ele, de modo que "poucas vezes, na modernidade, a beleza da linguagem em prosa alcançou tal grau de transparência e emoção, como se cada aventura ou episódio pairasse numa zona intemporal e inespacial, próxima da lenda ou do mito".

Consumado o projeto de escrita de $O$ tempo e o vento, Erico Verissimo envereda-se por outros caminhos, mas não abandona o seu dever de escritor e de intelectual de "tomar partido contra todas as injustiças, de onde quer que venham" (SARTRE, 2006, p. 209), e assim o escritor vai se voltar para outras sociedades oprimidas, abordando em seus romances 
alguns conflitos fora das fronteiras brasileiras, como acontece nos romances $O$ senhor embaixador e O prisioneiro, publicados em 1965 e 1967.

Mas, antes de passarmos a esses romances é necessário fazermos algumas considerações sobre Noite (1995f), obra publicada por Erico Verissimo em 1954, em meio ao processo de escrita de $O$ tempo e o vento, que desconcertou os seus leitores, já acostumados a um conteúdo ficcional sempre pautado no predomínio do coletivo sobre o individual.

Noite, considerada uma novela pelo fato de ter só um núcleo dramático e poucas personagens, narra a história de um homem, o Desconhecido, que perdeu a memória e vaga sozinho durante a noite pela cidade até ser encontrado por dois homens, o Corcunda e o Homem do Cravo, que o acompanham e exploram a sua condição de desmemoriado. Os três perambulam por diversos lugares imundos durante a madrugada, revelando a sordidez desses ambientes escondida durante a luz do dia e nem sempre percebida à noite.

O Desconhecido vive um drama: perdeu a memória ao entardecer e teme ter cometido um crime passional e um assalto ocorridos no início daquela noite. Como sinal de esperança para ele, surge o Homem de Branco e sua gatinha, que o acompanha a certa distância. Depois de uma angustiante noite de perambulações pelo submundo noturno da cidade, o Desconhecido recupera a memória ao acordar no quarto de uma prostituta e retorna para casa na esperança de que a esposa o tenha perdoado e esteja lá. Assim tomamos conhecimento de que a amnésia do Desconhecido foi causada pela briga com a esposa.

Moysés Vellinho (2005) considerou Noite um livro desconcertante, desses que dá para melindrar sensibilidades desprevenidas, pelo fato de a novela ir diretamente contra tudo aquilo que Erico Verissimo havia feito e estava fazendo até então. O ambiente da narrativa é noturno, sombrio, angustiante, ao contrário da atmosfera de todas as outras obras do autor publicadas anteriormente, nas quais predominam a claridade, a esperança e o otimismo, muitas vezes até exagerados. Outro elemento diferenciador e causador de surpresa é 
abordagem de um destino individual e não de um grupo de pessoas, como acontece nos outros romances do escritor.

Moysés Vellinho foi quem primeiro arriscou uma interpretação da intrigante novela. Para ele, por mais que ela divirja radicalmente de tudo o que Erico Verissimo tinha publicado antes, "é o livro mais próximo de sua intimidade, aquele através do qual ele diz mais de si mesmo, da verdade menos aparente, a verdade que ele traz recalcada nos desvãos mais ocultos da alma" (VELLINHO, 2005, p. 56). Dessa forma, para o crítico, a novela tem um caráter de confissão e corresponde ao acesso ao outro mundo do romancista, um território fechado e obscuro, conhecido apenas por ele mesmo. Nesse sentido, a obra é um exorcismo dos fantasmas interiores do escritor, por mais que eles estejam disfarçados na atmosfera surrealista da narrativa, e assim, segundo ele, "temos finalmente o livro em que Erico Verissimo começa a confessar-se, a mostrar o fundo de si mesmo, o outro lado da sua alma." (VELLINHO, 2005, p. 57).

A interpretação feita por Moysés Vellinho serviu como ponto de partida para Flávio Loureiro Chaves (2001) buscar outra, complementar à primeira, que ligasse Noite ao projeto literário de Erico Verissimo, sem que essa obra parecesse um corpo estranho no conjunto da produção literária do escritor. Chaves partiu da seguinte observação feita por Vellinho:

Em sua perplexidade sufocante, o Desconhecido parece encarnar, sob forma difusa, o drama do homem que não encontrou, na busca introspectiva, qualquer motivo transcendente de afirmação, nada que lhe desse, em termos apreensíveis, o sentido substancial, e não apenas existencial, dos seres e das coisas - da vida enfim. (VELLINHO, 1972, p. 112)

A partir dessa observação, Flávio Loureiro Chaves interpreta Noite como uma grande alegoria da perda da identidade do indivíduo diante da tirania da estrutura da vida social urbana, considerando que a obra remete para as formas mais radicais do realismo do escritor. Nesse sentido, a novela estaria diretamente ligada aos romances do ciclo de Porto Alegre. Segundo o professor: 
A expressão mais profunda da narrativa está ancorada nessa incômoda sensação de esvaziamento do "eu", de perda do domínio sobre a própria individualidade, que advém do confronto com a engrenagem absurda da vida imposta, no momento em que se intui, embora nebulosamente, o seu caráter imperativo. Sendo este o tema fundamental de Noite, é evidente que aí se constitui o termo mais radical da indagação sobre a vida urbana, e o ambiente alucinatório desta novela está intimamente vinculado com o "realismo social" dos romances publicados entre 1933 e 1943. (CHAVES, 2001, p. 117)

Depois dessa primeira observação, Chaves também vai relacionar Noite aos romances posteriores de Erico Verissimo, ao fazer um analogia entre a jornada do Desconhecido noite adentro às buscas da identidade empreendida por Floriano Cambará, na parte final de $O$ arquipélago, último romance da trilogia, e pelas personagens de $O$ prisioneiro. Dessa forma, considerando a novela uma expressão alegórica da crise da identidade, o professor conclui:

Vista por essa perspectiva, Noite, já não parece uma exceção no conjunto da produção literária do escritor. Ao contrário, só poderia ter surgido no preciso instante que surgiu: após a publicação de $O$ retrato e antes d' $O$ arquipélago. Isto é, naquela altura onde a ação de $O$ tempo e o vento já se desprende da reconstituição de um passado remoto para projetar as personagens no áspero cenário da atualidade. (CHAVES, 2001, p. 122)

Assim sendo, a partir dessa reflexão feita por Flávio Loureiro Chaves, podemos considerar Noite como uma obra ajustada ao projeto literário de Erico Verissimo, e não mais como uma obra à margem dele, conforme se pensou durante muito tempo.

Depois da conclusão da trilogia $O$ tempo e o vento, a obra literária de Erico Verissimo entrou numa nova fase e, conforme a observação feita por Ana Letícia Fauri (2005, p. 204), o escritor passou "a ver o mundo com os olhos de quem não se satisfaz com a realidade até então mostrada em seus livros". Nesse sentido, o professor Flávio Loureiro Chaves (1972, 2001) identificou nos romances $O$ senhor embaixador, $O$ prisioneiro e Incidente em Antares, publicados depois da trilogia, a radicalização do pensamento social do romancista e certo ceticismo sobre a condição humana, num contexto onde o liberalismo político estava em vias de se extinguir diante dos extremismos ideológicos acentuados pela Guerra Fria. Segundo ele, 
Após a reflexão histórica de $O$ tempo $e$ o vento a narrativa de Erico Verissimo chegou a um ponto crítico no qual já se tornou inviável o otimismo presente nos seus primeiros romances e que, em certa ocasião, mereceu contundentes objeções da parte de Álvaro Lins. Compreendida entre 1932 e 1971 de Fantoches ao Incidente em Antares - a sua ficção se desdobra por diferentes etapas durante um período de quarenta anos, sempre mantendo a arguição sobre a realidade social contemporânea. Digamos então que, com o passar do tempo, a própria natureza dos fatos históricos foi modificando a atitude do romancista perante a realidade imediata e forçou-o revisar constantemente as posições éticas através das quais ordenou o mundo da ficção. (CHAVES, 2001, p. 141)

Dessa forma, a escalada da violência no decorrer do século XX, as duas Guerras Mundiais, a Guerra Civil Espanhola, a Guerra Fria, a Guerra da Argélia, a Guerra da Coreia, a Guerra do Vietnã, as políticas imperialistas tanto dos Estados Unidos quanto da União Soviética, e as ditaduras latino-americanas, levaram o escritor a "uma desencantada visão do mundo presente" (Ibid., p.144). A partir de então, o círculo de giz, a que suas personagens estavam presas nos primeiros romances, transforma-se na Grande Engrenagem, à qual os seres humanos estão presos e incapazes de se libertarem dela. Nesse sentido, é valido lembrar um comentário de Erico Verissimo sobre o angustiante contexto histórico-político dos anos 60, presente na capa de $O$ prisioneiro. O escritor, ao ver os três netos brincando enquanto lia o jornal imaginou o mais velho tornando-se soldado e participando de uma guerra, sendo depois morto em combate. Diante de tal pensamento, o romancista se pergunta:

Por quê? Em nome de quê ou de quem? É estúpido e criminoso arrancar um rapaz do convívio da família, da comunidade ou da universidade para atirálo numa guerra sórdida e insensata, em nome de mitos ou de fantasias geopolíticas. O otimista, um dos alegres inquilinos do meu ser, reagiu: Não seja mórbido! Daqui a nove anos, quando teu neto estiver em idade militar, esses problemas todos estarão resolvidos... Mas o pessimista que habita o meu sótão interior, replicou: Era exatamente isso que se dizia em 1950, durante a campanha da Coreia...

Um ano mais tarde, já no Brasil, eu entregava à Editora Globo os originais de $O$ prisioneiro, espécie de parábola moderna em torno de alguns aspectos da estupidez humana, como a guerra e o ódio racial, bem como um comentário à margem das muitas prisões do homem, como peça da Grande Engrenagem. (...) Compreendi, há muito, que não podia continuar sentado à sombra duma árvore, silencioso e omisso, vendo e sentindo o mundo e as 
dores de seu tempo através apenas de notícias de jornal. (VERISSIMO, $1970)^{8}$

Uma das consequências da radicalização do pensamento social do escritor foi a abordagem de temáticas universais que ele passou a fazer, refletindo sobre os dramas enfrentados pelo ser humano em qualquer lugar que ele esteja, de forma que, segundo Guilhermino César (1972, p. 53-69), "os seus três últimos romances poderiam situar-se em qualquer parte do mundo", pois apresentam "três cidades, três culturas diversas entre si, mas uma só natureza humana perplexa e desarvorada." A esse respeito, numa entrevista concedida a Celito Grandi (1997) em 1971, ao ser questionado pelo entrevistador sobre a função social da literatura, Erico Verissimo responde que não vê como um romancista que escreve sobre o mundo contemporâneo pode deixar de abordar os problemas sociais e políticos que lhe saltam diariamente na cara, principalmente quando a ciência e tecnologia estão transformando o mundo num pequeno vizindário e assim "o que dói na carne dum vietnamita ou dum dominicano de certo modo dói também na nossa" (Ibid., p. 63).

Assim sendo, a literatura de Erico Verissimo vai reproduzir uma solidariedade humana universal e refletir sobre os as inquietações políticas do período da Guerra Fria, o que implica a retomada de alguns valores do malogrado romance Saga e a complementação de uma evolução do pensamento do escritor iniciada em $O$ arquipélago, quando o autor transformou a discussão política num dos principais temas dos seis capítulos de "Reunião de família", pelo fato de que ele vai passar a dar mais ênfase à condição humana e aos dilemas ideológicos.

Desse modo, no romance $O$ senhor embaixador, publicado em 1965, Erico Verissimo deixa o espaço ficcional brasileiro e retrata uma revolução contra a ditadura de Juventino Carreira, na fictícia República de Sacramento, localizada na América Central. Esse país fictício foi considerado por Guilhermino César (1972, p. 53) como um "compêndio de toda

\footnotetext{
${ }^{8}$ Citação extraída da capa da $3^{\mathrm{a}}$ impressão da $1^{\text {a }}$ edição, realizada em 1970.
} 
América Latina", refletindo e denunciando a sua imaturidade política, os seus ardis diplomáticos, as suas ditaduras constitucionais, os idealismos frustrados de seus habitantes, bem como seus instintos à solta. A opinião do crítico é compartilhada por Daniel Fresnot (1977, p.36), que vê na República de Sacramento um resumo de "todos os aspectos negativos da conturbada vida social e política da América Latina" dos anos 50 a 70.

Nessa mesma perspectiva, Joaquim Rodriguez Suro (1985, p. 210) considera que o romancista resumiu a situação latino-americana "vista na perspectiva da teoria do capitalismo dependente", ao denunciar e criticar a política intervencionista dos Estados Unidos nos países latino-americanos que estabelecem reformas que divergem dos interesses econômicos norteamericanos na região, apontando, inclusive, a contradição existente entre a ideologia política norte-americana, democrática e liberal, e sua exploração econômica predadora dos países latino-americanos

A ação do romance é ambientada na cidade de Washington e na República de Sacramento, onde se dão os conflitos políticos-ideológicos e existenciais das personagens numa intrincada e complexa teia narrativa, construída através das técnicas do contraponto e da polifonia, na qual todos têm direito a expressar seus pontos de vista, por meio da voz de um narrador em terceira pessoa, que, conforme definição de Donaldo Schuler (2000), vê os acontecimentos de perto e penetra na psique das personagens. Esse narrador, segundo a professora Márcia Ivana de Lima e Silva (1992, p.112): "assume alternadamente os diferentes posicionamentos referentes a cada personagem, conduzindo a narrativa de maneira que haja a interação dos diferentes discursos."

Pelo fato de sua estrutura romanesca ser construída através do princípio da polifonia, o romance comporta um coro de vozes que podem ser convergentes ou divergentes, de modo que o narrador sempre mostra uma mesma questão vista por diversos ângulos, de acordo com a perspectiva de cada personagem. Nesse sentido, o livro é um legítimo "romance de ideias", 
conforme a concepção bakhtiniana (BAKHTIN, 1997), pois, conforme acertadamente observou Wilson Chagas (1999, p. 106), as suas personagens "encarnam ideias e é em função delas que a narrativa é montada".

Dois anos depois, Erico Verisismo desloca o cenário de discussão política para a Ásia com a publicação de $O$ prisioneiro, romance que narra o processo de descolonização de uma ex-colônia francesa asiática que passa por uma intervenção norte-americana. Embora o autor não dê nome a ela, não há dúvida de que o espaço geográfico é o Vietnã. O tema dessa obra conforme observou Joaquim Rodriguez Suro (1985, p.225), "tem como finalidade acusar a intervenção norte-americana como um absurdo e alienante terrorismo institucionalizado. (...), focando os efeitos alienantes tanto nos vietnamitas como nos norte-americanos", mostrando assim alguns aspectos da estupidez humana, entre eles a guerra e o racismo, que leva os homens a se odiarem e a se destruírem, conforme o próprio escritor afirma na capa do livro.

Além do tom nitidamente político que a narrativa apresenta como elemento de denúncia do imperialismo norte-americano, há também o choque entre as culturas e as diferentes visões de mundo entre orientais e ocidentais que levam ao racismo extremado, entremeados pelos conflitos pessoais de cada uma das personagens, que não possuem uma identidade própria e são apresentadas ao leitor pelo nome de suas atividades sociais: o tenente, o coronel, o major, a professora, a prostituta e o prisioneiro vietnamita.

O principal núcleo dramático do romance é a missão que o tenente mulato norteamericano recebe de interrogar um prisioneiro vietnamita e fazê-lo revelar o local em que foi colocada uma bomba que está para explodir naquele mesmo dia, cinco horas depois da explosão de um café, a qual vitimou dezenas de pessoas. Para executar a missão, o tenente deve usar até mesmo o mecanismo da tortura, se necessário. No entanto, através de uma estrutura narrativa semelhante à utilizada em $O$ senhor embaixador, tendo por base o 
contraponto e a polifonia, o narrador que é onisciente ${ }^{9}$ e tem uma visão por trás dos acontecimentos, vai nos apresentando os dramas pessoais de cada uma das principais personagens e assim percebemos que, ao fim e ao cabo, o prisioneiro não é só o vietnamita preso e sim todas as demais personagens do romance, conforme admite o próprio autor numa entrevista concedida a Adolfo Braga em 1967, na época do lançamento do livro:

O prisioneiro não é só o vietcong que plantou a bomba e que está sendo interrogado e torturado. Prisioneiros são também todos os demais personagens e de certo modo o próprio autor do livro é igualmente um prisioneiro. Ao escolher para o papel de inquisidor um tenente negro, eu também pude incluir na minha história o problema do homem de cor norteamericano. Existem 30 por cento de soldados negros lutando no Vietnã. Eles defendem uma civilização que os repudia e esse é um dos absurdos de toda a situação. Estamos em tempo de guerra, de injustiças, absurdos, equívocos, mortes e destruição. (BRAGA, 1997, p. 27-28)

Desse modo, Erico Verissimo vê não só as suas personagens, mas também todos os seres humanos como prisioneiros daquilo que denominou de a Grande Engrenagem, que em nome de interesses políticos e econômicos sujeita todas as pessoas, até mesmo aquelas que têm a ilusão de serem livres. Nesse sentido, a liberdade humana só pode ser restituída a partir da desmontagem da monstruosa Engrenagem, conforme fica nítido nas palavras da professora, a porta-voz do autor na narrativa:

Estamos outra vez tropeçando em palavras. Mas a verdade é que jamais nos livraremos de sua tirania. Nem da nossa teologia ou da nossa mitologia particular. Eu prefiro dizer, sinceramente, que você é, antes de mais nada, uma vítima da Engrenagem. E que é preciso desmanchar essa Engrenagem e recomeçar tudo sobre bases novas. É um trabalho para séculos, mas alguém em alguma parte um dia tem de começar. (VERISSIMO, 19951, p. 178)

A radicalização do pensamento social de Erico Verissimo vai se completar em Incidente em Antares, romance publicado em 1971, no qual o escritor volta a utilizar a

\footnotetext{
${ }^{9} \mathrm{O}$ narrador propositalmente abandona a onisciência durante o interrogatório do prisioneiro vietnamita que se nega a revelar o local em que foi colocada a segunda bomba.
} 
história, a política e a sociedade brasileira como matéria ficcional e constrói uma narrativa "a partir de dois aspectos principais: os interesses políticos como determinantes das relações sociais e a denúncia da violência em qualquer nível, seja ideológico, político ou físico" (SILVA, 2000, p. 19)

Nesta obra que fecha o seu projeto literário, Erico Verissimo faz uma espécie de paródia de $O$ tempo e o vento, retomando o mesmo material histórico utilizado na trilogia, mas deslocando a crítica para o nível do discurso, conforme observa Márcia Ivana de Lima e Silva (2000), ao contar, na primeira parte do romance, a história do desenvolvimento da cidade de Antares atrelada à história do estado e da nação, e tendo como fio condutor a rivalidade histórica de duas famílias tradicionais, os Vacarianos e os Campolargos, que se unem em torno da figura de Getúlio Vargas na Revolução de 30 com o nítido propósito de manter os seus privilégios.

Na segunda parte do romance, intitulada "O incidente", que ocupa a maior parte do livro, o escritor traz um elemento novo em sua ficção, o fantástico, ao ressuscitar sete defuntos insepultos e fazê-los marchar para a praça de Antares, onde, na condição de quem não têm mais nada a perder, põem a nu todas as mazelas daquela sociedade que, de forma metonímica, pode ser estendida à toda sociedade brasileira da época. Coerente com o seu projeto literário, os defuntos pertencem a diferentes estratos sociais: Quitéria Campolargo, mulher rica e integrante de uma das tradicionais famílias da cidade; o advogado Cícero Branco; o operário João Paz; o músico Menandro Olinda; a prostituta Erotildes; o anarquista José Ruiz, conhecido como Barcelona; e o bêbado Pudim de Cachaça. Nesta segunda parte, também há uma paródia de O tempo e o vento, pois, segundo Maria da Glória Bordini (2003) todas as personagens-defuntos são reescrituras de personagens-tipo da trilogia.

Servindo-se das mesmas técnicas narrativas utilizadas nos romances anteriores, Erico Verissimo constrói uma narrativa de denúncia, utilizando-se de quatro narradores diferentes, 
conforme observa Márcia Ivana de Lima e Silva (2000): o narrador-historiador, o professor Martim Francisco Terra (porta-voz do escritor), o jornalista Lucas Faia e o narradororganizador, que é introduzido na narrativa para dar voz aos defuntos no confronto com os vivos na praça de Antares. O episódio é construído como se fosse um julgamento e é pela voz do advogado Cícero Branco, porta-voz dos mortos que são suas testemunhas de acusação, que são expostas todas as mazelas políticas e sociais de Antares e, principalmente, a podridão moral que cerca as principais figuras da cidade, tais como o delegado e o prefeito. Segundo Flávio Loureiro Chaves (2001, p. 148), "apenas eles, investidos duma autoridade moral só concedida pela própria morte, veem e revelam o miolo apodrecido da coletividade".

Dessa forma, com Incidente em Antares, Erico Verissimo fecha o seu projeto literário que, por mais que tenha tido algumas oscilações num percurso de quase 40 anos, sempre manteve uma coerência ética alicerçada no compromisso do escritor de revelar a engrenagem social e seus mecanismos, mostrando o homem na sua dinâmica social e o indivíduo em sua humanidade e denunciando todas as formas de violência e arbitrariedades cometidas contra os seres humanos de qualquer parte do mundo. Nesse sentido, esse romance escrito num dos períodos mais negros da ditadura militar brasileira, é também conforme observou Antônio Candido (2001, p. 16-17), "uma sátira sangrenta contra o regime militar, que estava em plena força e Erico enfrentou com as armas da literatura". 


\section{A TRILOGIA $O$ TEMPO E O VENTO: UMA SAGA FAMILIAR E UMA NARRATIVA DE FUNDAÇÃO ENGAJADA}

\subsection{Uma narrativa de fundação engajada}

A trilogia $O$ tempo e o vento representa o ponto máximo da literatura de Erico Verissimo, é a culminação do seu projeto literário de realizar um corte transversal de uma sociedade. Para elaborá-la, o escritor escolheu o tema da formação do Estado do Rio Grande do Sul, partindo da história de uma família, que por sua vez se liga à história do desenvolvimento de uma cidade, do estado e da própria nação. Dessa forma, o escritor elegeu a narrativa de uma saga familiar para compor o romance de fundação do estado gaúcho, através do uso da "técnica de redução", que concentra "o tempo social e o espaço social de um Estado ao tempo e ao espaço doméstico de uma só família" (LOPEZ, CAÑIZAL, 1969).

Embora Erico Verissimo não saiba determinar com exatidão quando lhe ocorreu pela primeira vez a ideia de escrever $O$ tempo e o vento, a professora Maria da Glória Bordini (1995, p.127) afirma que esse projeto remonta a 1939, quando o romancista estava para escrever Saga, conforme ela infere de uma conferência proferida por ele nesse mesmo ano, na qual o escritor revela que tinha a intenção de começar a escrever um volumoso romance cíclico que se chamaria Caravana e abrangeria 200 anos da história do Rio Grande do Sul. No entanto, de acordo com a professora Bordini, o contexto histórico e político da véspera da Segunda Guerra Mundial não lhe pareceu propício para começar o longo empreendimento e ele preferiu voltar-se para o presente e começar a escrita de Saga.

O projeto só seria retomado pelo escritor após queda de Getúlio Vargas em 1945, acontecimento que certamente colaborou para a ampliação da extensão cronológica do projeto 
original que previa o término da saga em 1940, pois, como sabemos, cerca de um terço da matéria ficcional histórica da trilogia provém da era Vargas.

Em seu livro de memórias Solo de Clarineta - volume I (1995p), Erico Verissimo comenta sobre o propósito de escrever essa obra ambiciosa e, principalmente, das dúvidas e angústias que o projeto lhe gerava:

Antes de começar o "ambicioso projeto", eu precisava vencer muitas resistências interiores, a maioria delas originadas nos meus tempos de escola primária e ginásio. Para o menino e para o adolescente - ambos de certo modo sempre presentes no inconsciente do adulto - , o poético, o pitoresco e o novelesco eram atributos que raramente ou nunca se encontravam em pessoas, paisagens e coisas do âmbito nacional e muito menos do regional e ainda menos do municipal. Nossos livros escolares - feios, mal impressos em papel amarelo e áspero - nunca nos fizeram amar ou admirar o Rio Grande e sua gente. Redigidos em estilo pobre e incolor de relatório municipal, eles nos apresentavam a História do nosso Estado como uma sucessão aborrecível de nomes de heróis e batalhas entre tropas brasileiras e castelhanas. (Ganhávamos todas). Nossos pró-homens pouco mais eram que nomes inexpressivos, debaixo de clichês apagados, em geral de retícula grossa: sisudos generais, quase sempre de longas costeletas, metidos em uniformes cheios de alamares e condecorações; estadistas de cara severa especados em colarinhos altos e engomados. (...) Conclui então que a verdade sobre o passado do Rio Grande devia ser mais viva e bela que a sua mitologia. E quando mais examinava a nossa História, mais convencido ficava da necessidade de desmitificá-la.

(...)

Cabia, pois, ao romancista descobrir como eram "por dentro" os homens da campanha do Rio Grande. Era com aquela humanidade batida pela intempérie, suada, sofrida, embarrada, terra-a-terra, que eu tinha de lidar quando escrevesse o romance do antigo Continente. Talvez o drama de nosso povo estivesse exatamente nessa ilusória aparência de falta de drama. (...)

E assim, depois que compreendi tudo isso, as personagens para o projetado e sonhado romance me foram saindo da memória, como coelhos duma cartola de mágico. (VERISSIMO, 1995p, p. 288-295)

Nesse sentido, o projeto de escrita da grandiosa obra foi para o escritor uma necessidade pessoal de descobrir a verdadeira identidade do seu povo, encoberta pela historiografia oficial que só via homens valentes, de faces severas, rudes e sisudos que figuravam na categoria de heróis. Para isso era preciso desconstruir o estereótipo do homem rio-grandense, revelando os diversos tipos e grupos sociais que habitavam o Rio Grande do Sul e trazendo à luz as várias facetas do povo gaúcho, bem como desmitificar a história do 
estado. No mesmo texto, Erico Verissimo ainda revela que era um desenraizado, tinha aversão ao campo e sentia-se desligado do seu ambiente social, sempre mergulhado em leituras e meditações, de forma que isso veio a refletir diretamente em sua literatura, pois, embora ela tivesse uma preocupação social desde o seu primeiro romance, ele não conseguia penetrar e revelar a essência dos grupos sociais rio-grandenses. Nesse aspecto, a obra planejada seria também um reencontro consigo mesmo, com sua terra, com suas raízes e poria termo às muitas angústias do escritor, além de mostrar as suas reais possibilidades como romancista.

Dessa forma, a fórmula planejada por Erico Verissimo para a elaboração da obra se assemelha à receita pensada por Alejo Carpentier ((1971, p. 92) para o engajamento literário do escritor latino-americano: "partir do próprio rincão, e subir do particular ao universal", ou seja, começar por suas raízes para depois alcançar a universalidade, de modo que romancista observe e compreenda o seu mundo particular e depois dê uma visão do mundo a ele, sempre partindo do seu "compromisso com esse mundo". Carpentier via na figura do romancista latino-americano alguém com um importante papel social a cumprir na tarefa da representação de seus povos, de suas nações e de seu continente, que por sua vez contribuísse para um despertar de consciências que pudesse melhorar esse mundo habitado por eles, tal como fez Erico Verissimo na escrita de O tempo e o vento, ao escolher como tema a história da formação da sociedade do seu estado, atrelada à formação do Brasil, e se valer de estratégias narrativas que pudessem discutir tanto a sociedade local quanto as questões nacionais.

Pelo fato de abordar a história dos Terra-Cambará imbricada com a história da formação do Rio Grande do Sul e do Brasil, num perfeito entrelaçamento entre ficção, mito, história e política, $O$ tempo e o vento também se constitui como uma narrativa de fundação, participando "da melhor tradição romântico-realista de escrever a nação por meio da ficção, atribuindo-se correlações entre localismo e nacionalismo" (HELENA, 2005, p. 168-169). 
Nesse sentido, segundo Lúcia Helena, o projeto da narrativa de fundação que surge na ficção das Américas no século XIX "está presente na obra de Erico Verissimo, associando uma dupla matriz de procedimentos que, se no século XIX se contrapunham, culminam, em $O$ tempo e o vento, por complementarem-se (Ibid, p. 176).

Os dois procedimentos referidos pela professora são, de um lado, o tópico da origem do nacional vinculado à cor local e, de outro, a rasura do tópico da origem para não se deixar levar pelo exagero na equivalência entre a cor local e o nacionalismo, que pode descambar num regionalismo periférico ou num nacionalismo panfletário. Diante desses dois procedimentos que se contrapunham na narrativa do século XIX, Erico Verissimo aciona-os "e os complementa com rara sabedoria" (Ibid.).

Lúcia Helena, ao lembrar que a inserção de Erico Verissimo no âmbito das narrativas de fundação é muito pouco estudada pela crítica literária, afirma que o escritor gaúcho,

conseguiu elaborar bem, e de modo muito próprio, alguns dos obstáculos existentes nesse projeto fundacional, que foi, de certo modo, abandonado pelo próprio Mário de Andrade depois de Macunaíma, e só muito recentemente foi retomado por João Ubaldo Ribeiro. De um lado, Erico Verissimo vence a plenitude dos textos românticos, incorporando com maestria a constante mudança de foco e de estratégia narrativa, num texto tecnicamente muito elaborado que, todavia, não perde em comunicabilidade. Por outro lado, antecipa questões que, trabalhadas em 1984 por João Ubaldo Ribeiro, ficaram distantes do olhar de Mário de Andrade como, por exemplo, a necessidade de se discutir, para além da desagregação fragmentária, o rosto possível do Brasil, mesmo tendo de enfrentar a questão do essencialismo, que sempre aí ressoa. (HELENA, 2005, p. 181)

A afirmação de Lúcia Helena vai ao encontro do pensamento dos professores Flávio Loureiro Chaves (2001), Maria da Glória Bordini (2004) e Regina Zilberman (2004). Para eles, O tempo e o vento representa muito mais que a principal obra literária escrita por Erico Verissimo e merece um papel de destaque na história da Literatura Brasileira, pelo fato da trilogia ter resolvido um problema antigo de nossa literatura: encontrar um modelo padrão para o romance histórico. Nesse sentido, Flávio Loureiro Chaves afirma que $O$ tempo e o 
vento foi a resolução formal do romance histórico brasileiro, procurada desde o Romantismo por José de Alencar:

Erico Verissimo instaurou um romance histórico em sua forma exemplar. A descendência da família Terra/Cambará em várias gerações coincide com a fundação da cidade de Santa Fé; esta, por sua vez, traduz uma síntese do Rio Grande do Sul, passando daí ao retrato da sociedade brasileira. Dimensionase assim, nessa escala de ampliação, o corte transversal proposto pelo narrador.

Ocorre que o mural representativo da nossa formação, fixando tanto os mitos fundadores quanto a sequência dos fatos, também não era uma ideia nova. Vinha do romantismo nacionalista (leia-se Alencar) e reapareceu em diversas correntes do modernismo a partir dos anos 20, rondando até a concepção do Macunaíma de Mário de Andrade. O volume inaugural de $O$ tempo e o vento, em 1949, não incorporou, pois, à ficção o "projeto" do romance histórico, que já era antigo. Erico Verissimo ofereceu, isto sim, a chave da sua resolução formal que, fossem quais fossem os antecedentes, não havia sido encontrada até então. Esse é o motivo pelo qual constitui um marco decisivo. (CHAVES, 2001, p. 105)

Maria da Glória Bordini e Regina Zilberman endossam a opinião de Flávio Loureiro

Chaves quanto ao papel original que esses três romances ocupam no desenvolvimento da narrativa de ficção histórica brasileira, e reclamam o reconhecimento desse aspecto inovador:

Nenhum historiador da literatura brasileira negaria o papel seminal que $O$ tempo e o vento, de Erico Verissimo, exerceu desde a publicação de $O$ continente, primeiro volume da trilogia, em 1949. (...)

Com o passar do tempo e o aparecimento dos volumes subsequentes da trilogia, $O$ retrato, em 1951, e $O$ arquipélago, entre 1961 e 1962, foi consolidando o consenso: estava-se diante da realização de um antigo projeto da sociedade e da cultura brasileira, enfim concretizado. Dificilmente um historiador da literatura brasileira, bem-intencionado e bem informado deixará de reconhecer e registrar esse aspecto. (BORDINI, ZILBERMAN, 2004, p. 13-14)

Dessa forma, Flávio Loureiro Chaves, Maria da Glória Bordini e Regina Zilberman assinalam o feliz cruzamento do projeto literário do escritor, realizar "um corte transversal da sociedade", com um antigo projeto da Literatura Brasileira, encontrar um modelo padrão para o romance histórico, ou para o romance de fundação, conforme o pensamento de Lúcia Helena. Assim, tanto o conteúdo ficcional de $O$ tempo e o vento encontra-se associado ao 
desenvolvimento da nação, quanto a obra ficcional se encontra atrelada ao desenvolvimento da narrativa brasileira.

Conforme já informamos na introdução, lembramos que embora o conjunto de $O$ tempo e o vento seja mais conhecido como um romance histórico ${ }^{10}$, optamos nessa pesquisa pela sua abordagem como uma narrativa de fundação, no sentido definido por Lúcia Helena (2005, p.176) como "um fenômeno híbrido, parte artístico-literário, parte histórico-político, no qual, por meio da ficção, criam-se 'comunidades imaginadas'", pelo fato de que a nomenclatura e a definição de "narrativa de fundação" abarca os aspectos ficcional, histórico, político e mítico da narrativa, sem prejuízo ou exclusão de nenhum deles, e também nos permite, em consonância com os pensamentos de Lúcia Helena, Flávio Loureiro Chaves, Maria da Glória Bordini e Regina Zilberman, inserir Erico Verissimo numa corrente diacrônica de desenvolvimento da Literatura Brasileira que, partindo de José de Alencar, passando por Mário de Andrade e por ele chega a João Ubaldo Ribeiro.

No entanto, à narrativa de fundação acrescentamos o adjetivo "engajada", que talvez soe redundante para muitos que a consideram engajada na sua essência, mas que para nós se torna importante na medida em que pretendemos mostrar que foi a utilização de alguns pressupostos do engajamento literário, do modo como foi teorizado por Jean-Paul Sartre, que permitiram a Erico Verissimo elaborar uma narrativa de fundação que conseguiu superar os obstáculos existentes no projeto fundacional do romance brasileiro do século XIX, conforme aponta Lúcia Helena (Op. cit.).

\footnotetext{
${ }^{10}$ Há algumas controvérsias sobre a conceituação da trilogia $O$ tempo e o vento como romance histórico, devido a mudança de natureza do primeiro romance, $O$ continente, para $O$ retrato e $O$ arquipélago, e também por causa de que o tempo histórico abordado nos dois últimos romances seja um tempo vivido diretamente por Erico Verissimo, dado que faz muitos críticos, entre os quais Seymour Menton (1993), considerarem apenas $O$ continente como romance histórico. Essa situação já foi analisada por nós no artigo "O tempo e o vento: romance histórico e romance político", publicado no Cadernos do IL nº 39.
} 
Nesse sentido, a proposta de escrita de O tempo e o vento - desmitificar a história do Rio Grande do Sul e do seu povo, mostrando como eram por dentro os homens da campanha e como o estado gaúcho estava povoado pelos mais variados tipos humanos - já é, por si só, engajada, pois representa a realização de "uma retomada total do mundo, é uma recuperação da totalidade do ser, que é apresentada ao leitor para que ele possa recuperá-lo através da leitura, pois é bem esta a finalidade da arte: recuperar o mundo, mostrando-o tal como ele é" (SARTRE, 2006, p. 47). E, ao partir do próprio rincão, o autor se aproxima também do pensamento de Alejo Carpentier (1971), para quem a função social do romancista latinoamericano era ocupar-se do seu mundo local/regional, entender-se com ele e seu povo, representando-os, criticando-os, exaltando-os, amando-os e, principalmente, compreendendoos, de modo a falar dos seus erros, suas grandezas e misérias.

\subsection{As estratégias narrativas utilizadas para a desmitificação da história}

Para realizar a releitura crítica da história do Rio Grande do Sul com o objetivo de desmitificá-la, Erico Verissimo vai se valer da utilização de algumas estratégias narrativas, tais como a saga familiar, o contraponto, a polifonia e a metaficção. O uso dessas estratégias narrativas é que possibilitaram ao escritor alcançar o equilíbrio entre literatura de intervenção social e alta elaboração estética, obtendo assim uma ótima expressão literária, dado que foi fundamental para que Erico Verisismo conseguisse ultrapassar determinados obstáculos seja da narrativa fundacional ou da narrativa histórica brasileira do século XIX.

A seguir, faremos a análise de como essas estratégias são utilizadas e os efeitos estéticos que elas provocam. A técnica do contraponto possibilita ao escritor a estruturação dos romances que compõem a trilogia com dois tempos históricos, um diacrônico e outro 
sincrônico, de modo que se possa compreender o presente a partir do passado, e também permite ao escritor compor a narrativa com mais de uma história e assim inserir uma antihistória em contraposição à história oficial; enquanto que a polifonia, articulada por um narrador que possui onisciência total sobre o espaço e as personagens (visão por trás), possibilita ao autor inserir no tecido narrativo vozes que podem questionar ou desmentir a história e assim dar outras versões dos fatos históricos.

\subsubsection{A saga familiar}

A trilogia $O$ tempo e o vento constitui-se como uma saga familiar pelo fato de ter o seu principal núcleo narrativo centralizado na história da fictícia família Terra-Cambará, num período que abrange 200 anos, compreendido entre 1745 e 1945, no qual a história da família protagonista se entrelaça à história do desenvolvimento de uma cidade também fictícia, Santa Fé, do estado do Rio Grande do Sul e do Brasil. Nesse vasto período, os Terra-Cambará passam da condição inicial de colonos pobres à condição de família latifundiária e detentora dos poderes econômico, social e político, tanto em nível local, quanto regional e nacional, enquanto o estado do Rio Grande do Sul, o Brasil e o mundo passam por diversos acontecimentos históricos e políticos importantes como o Tratado de Madri, a Guerra Missioneira, a Independência do Brasil, a Guerra da Cisplatina, a Guerra dos Farrapos, a Guerra contra Rosas, a Guerra do Paraguai, a Abolição da Escravatura, a Proclamação da República, a Revolução Federalista de 93, a Primeira Guerra Mundial, a Revolução Russa, a Revolução gaúcha de 1923, a Coluna Prestes, a Guerra Civil Espanhola, a Revolução de 30, o Estado Novo, a Segunda Guerra Mundial e a deposição de Getúlio Vargas. 
A família Terra-Cambará é formada a partir de três núcleos. O primeiro deles é Pedro Missioneiro. Fruto de um estupro praticado por um bandeirante em uma índia que morre no parto, o menino é criado nos Sete Povos das Missões, de onde foge na noite em que a redução é tomada pelo exército português. O segundo núcleo é constituído pela família de Ana Terra, colonos pobres de origem portuguesa que vieram do interior de São Paulo para o Rio Grande do Sul nos primórdios da colonização do estado. E o terceiro núcleo vem do aventureiro Chico Rodrigues, que a partir da união com a açoriana Maria Rita passa-se a chamar Chico Cambará. Do encontro entre Pedro Missioneiro e Ana Terra nasce Pedro Terra, pai de Bibiana Terra que se casa com o capitão Rodrigo Cambará, descendente de Chico Cambará.

A condição social e econômica da família sofre uma significativa transformação quando Bibiana casa o filho Bolivar com Luzia Silva, neta do agiota Aguinaldo Silva. Com a morte de ambos, o seu neto Licurgo herda todos os bens da família da mãe, fato que deixa os Terra-Cambará na condição de uma rica família latifundiária. Dessa forma, o fim de $O$ continente apresenta Licurgo Terra Cambará como intendente municipal de Santa Fé, dono da grande estância de terras do Angico e do imponente sobrado, símbolo do prestígio social e poder político local, e um dos coronéis vencedores da Revolução Federalista de 93. Conforme a observação feita pela professora Regina Zilberman:

A família escolhida para paradigma, contudo, não é "média" ou "exemplar!": ela vai aos poucos, se elevando socialmente. Dos marginais Pedro Missioneiro e Chico Rodrigues provêm o acomodado Pedro Terra e o inquieto Rodrigo Cambará; mas o neto de um e filho de outro, Bolívar, casa com a rica herdeira Luzia Silva, o que garante o futuro tranquilo de Licurgo, figura que, ao contrário de seus ancestrais, não precisa ter preocupações financeiras ou profissionais. A elevação social tem seu preço: os Cambará chegam ao poder, quando o Intendente Licurgo, parceiro dos Republicanos e de Júlio Castilho, suplanta os maragatos por ocasião da disputa de Santa Fé. (ZILBERMAN, 2004, p.153-154) 
Em $O$ retrato e $O$ arquipélago, o foco da narrativa vai ser a ascensão e queda, tanto política quanto pessoal, do Dr. Rodrigo Terra Cambará. O filho caçula de Licurgo, assim que se forma em Medicina em Porto Alegre, retorna à Santa Fé e se junta ao pai e ao irmão Toríbio, na disputa que se trava pelo poder político na cidade, ao mesmo tempo em que se casa com Flora Quadros e tem com ela cinco filhos: Floriano, Alicinha, Jango, Eduardo e Bibi. Na sua trajetória, Rodrigo ocupa os cargos públicos de intendente municipal de Santa Fé e de deputado estadual, até tornar-se um dos homens mais influentes e poderosos do Estado Novo de Getúlio Vargas e, consequentemente, tem sua derrocada com a deposição de Vargas em 1945, no mesmo período em que sofre um infarto e vem a morrer. Além dele, há outras duas personagens importantíssimas nesses dois romances: Maria Valéria Terra, sobrinha de Bibiana e tia de Rodrigo, que já aparece nos capítulos de "O sobrado" em $O$ continente, e Floriano, o filho mais velho de Rodrigo, que aparece na parte final de $O$ retrato e será de suma importância em $O$ arquipélago.

Pelo fato de esses dois romances centralizarem-se na figura de Rodrigo Cambará, a professora Regina Zilberman (2004) observa a mudança de natureza que há entre eles e $O$ continente, com a história deixando de ser contraponto da narrativa para se tornar alimento dela.

\footnotetext{
A história não se mostra como algo independente, transparecendo antes por meio da atividade de Rodrigo, que se torna cada vez mais um agente dela. Isso determina a mudança da natureza das obras; e, se $O$ continente tinha elementos do romance histórico por incorporar a história à ação ficcional, mantendo-a, entretanto, como pano de fundo e fator de referência, $O$ arquipélago complementa o que $O$ retrato anunciava: é o romance de formação (Bildungsroman) por deter-se na biografia do protagonista, acompanhando sua ascensão e queda, até seu derradeiro momento vital. Esta passagem faz com que o último volume assuma caráter exemplar, com Rodrigo, de indivíduo, tornando-se representante de várias questões que interessam a Erico desde o início da trilogia, tais como: a formação das elites políticas do Rio Grande do Sul; a natureza do comportamento do homem regional; o contraste entre ética e vida pública. (ZILBERMAN, 2004, p. 36)
} 
Um elemento que ocupa um papel estrutural de extrema importância durante toda a trilogia é o sobrado, a residência oficial dos Terra-Cambará e local onde é ambientada a maior parte da narrativa, tanto que o próprio Erico Verissimo considerou-o como uma personagem de $O$ tempo e o vento. $\mathrm{O}$ sobrado passa a ser propriedade da família protagonista a partir do casamento entre Bolívar e Luzia, tornando-se o símbolo da ascensão social e econômica da família. Lembramos que o casarão foi construído bem no local onde ficava a casa de Pedro Terra que foi tomada pelo agiota Aguinaldo Silva, e dessa forma o casamento do filho de Bibiana com a neta do agiota significou a retomada da posse de um espaço que antes já pertencia à família Terra-Cambará.

De acordo com o professor Flávio Aguiar (2001, p. 209), o sobrado "está no centro e na convergência dos tempos e espaços" em toda narrativa.

O sobrado participa, como signo, cenário e vetor, dessa migração para o tempo histórico. Torna-se, inclusive, um espaço polivalente, exercendo uma pletora de funções diante da Santa Fé que confronta e em que reina, embora nem sempre governe (...). Estas sucessivas ou simultâneas funções que exerce guardam também um sentido histórico simbólico. É fortaleza inexpugnável. É cemitério, morgue, câmara ardente e hospital, abrigando feridos de pancadarias e de tiroteios durante as refregas e contendas. É o centro de conspirações carbonárias e é também uma espécie de ágora e salão, onde a pólis de Santa Fé debate ideias, política, filosofia, artes, agronomia, história, culinária e desfruta das modernidades, não faltando as bebidas características dos simpósios dos tempos clássicos. (AGUIAR, 2001, p. 216)

Nesse sentido apontado por Flávio Aguiar, e sendo o sobrado o ponto de onde a ação romanesca é desencadeada e também o ponto onde ela termina, podemos considerá-lo como o "cronotopo" de O tempo e o vento, no sentido definido por Mikhail Bakhtin (1998) como o "espaço-tempo" que em literatura representa a interligação das relações temporais artisticamente elaboradas, e constitui o centro organizador dos principais acontecimentos temáticos do romance, ou seja, é o ponto de partida das narrativas literárias. Para o teórico russo, 
No cronotopo artístico ocorre a fusão dos indícios espaciais e temporais num todo compreensivo e concreto. Aqui o tempo condensa-se, comprime-se, torna-se artisticamente visível; o próprio espaço intensifica-se, penetra no movimento do tempo, do enredo e da história. Os índices do tempo transparecem no espaço, e o espaço reveste-se de sentido e é medido com o tempo. Esse cruzamento de séries e a fusão de sinais caracterizam o cronotopo artístico. (BAKHTIN, 1998, p. 211)

Nesse aspecto, o sobrado enquanto cronotopo de $O$ tempo e o vento tem uma função similar àquelas exercidas pelos cronotopos do castelo e do salão-sala de visita, identificados por Bakhtin no romance inglês dos séculos XVIII e XIX (o primeiro) e nos romances de Stendhal e Balzac (o segundo), onde há o entrelaçamento entre que é particular e privado com o que é histórico, social e público; entre a intriga pessoal e a política, entre a série biográfica e a histórica (BAKHTIN, 1998, p. 352). Mas, também, podemos ver o sobrado como a "unidade de lugar", identificada pelo teórico russo no idílio familiar, que determina o conjunto da vida das gerações "pela ligação secular das gerações ao lugar único" e que "aproxima e funde o berço e o túmulo (...), a infância e a velhice (...), a vida das diversas gerações que viveram no mesmo lugar, nas mesmas condições, que viram as mesmas coisas" (BAKHTIN, 1998, p. 334).

A utilização da saga familiar para a estruturação da narrativa permite ao escritor realizar o entrelaçamento da história ficcional da família protagonista à história de desenvolvimento do estado do Rio Grande do Sul e do país, com os acontecimentos históricos sendo vividos, vistos e analisados a partir da perspectiva dessa família. Desse modo, o ponto de partida para a origem da família Terra-Cambará, que será extensiva, num processo de ampliação metonímica, à formação da sociedade gaúcha e brasileira, é o nascimento de Pedro Missioneiro, fruto de um estupro realizado por um bandeirante numa jovem índia que acaba morrendo no parto nos Sete Povos das Missões, e para a origem da formação do estado do Rio Grande do Sul o ponto escolhido é a Guerra Missioneira, fruto do Tratado de Madri, assinado 
em 1850, através do qual Portugal cedia à Espanha a Colônia de Sacramento (atual Uruguai) e em troca recebia Os Sete Povos das Missões.

Esses dois eventos são marcados pela violência. Pedro Missioneiro, como já afirmamos anteriormente, é fruto de um estupro cometido por um bandeirante, conforme pode-se depreender do trecho abaixo, quando o padre Alonzo, depois de ver a mãe moribunda se esvaindo em sangue, vai a ver a criança recém-nascida:

\begin{abstract}
Aproximaram-se dum berço tosco onde, no meio de panos de algodão, o recém-nascido dormia. Tinha a pele muito mais clara que a da mãe. Alonzo ergueu os olhos para o cura que sacudiu lentamente a cabeça, adivinhando os pensamentos do companheiro e dando a entender que participava também de suas suspeitas. Aqueles malditos vicentistas! - pensou Alonzo. Não se contentavam com prear índios e levá-los como escravos para sua capitania: tomavam-lhes também as mulheres, serviam-se vilmente delas e depois abandonavam-nas no meio do caminho, muitas vezes quando elas já se achavam grávidas de muitos meses. Aquele não era o primeiro caso e certamente não seria o último. (VERISSIMO, 1995h, p. 36)
\end{abstract}

Ao contrário da índia Iracema, do romance homônimo de José de Alencar, que se entrega por vontade ao português Martim, a mãe de Pedro Missioneiro é vítima da violência sexual cometida por um bandeirante da Capitania de São Vicente, e seu caso seria mais um entre milhares que houve no período de expansão portuguesa na América, e aí então vemos de forma alegórica toda a violência do empreendimento colonial português. Assim, Erico Verissimo não idealiza e nem propõe uma síntese harmoniosa dos contrários, conforme observou Lucia Helena (2005). Sem abandonar as convenções literárias, o seu objetivo é uma representação o mais realista possível do empreendimento colonial e por isso ele não oculta e nem disfarça a violência do processo. Aqui é pertinente lembrar uma observação feita por Walnice Nogueira Galvão (1979, p. 385) a respeito da interpretação de Octávio Paz sobre o estupro das mulheres nativas pelo colonizador europeu. Paz via nesse ato uma metonímia da "violação de uma civilização por outra, dando origem a uma população onde todos têm uma 
relação ambígua com pai e mãe fundadores, onde todos carregam o mal-estar de serem 'filhos da Malinche'".

Da mesma forma, a redução dos Sete Povos configurada no romance como "espaço sagrado e local paradisíaco" (ZILBERMAN, 2004, p. 42) ou um "éden sobre a terra" (BORDINI, 2004, p. 60) também vai sofrer uma violação brutal em decorrência do Tratado de Madri, sendo destruída pelo exército de Gomes Freire de Andrade, em nome da política colonial portuguesa de realizar "a posse geográfica efetiva da terra", colonizando-a, povoando-a ou despovoando-a, conforme a observação feita por Edward Said (1995, p. 118) sobre a luta imperial pela posse da terra.

Os dois eventos que mencionamos, o nascimento de Pedro Missioneiro e a Guerra Missioneira, a partir da qual o Continente de São Pedro, antigo nome do Rio Grande do Sul, foi incorporado ao território português, funcionam na estrutura do romance como um “momento axial”, termo utilizado por Paul Ricouer para designar:

\footnotetext{
Um acontecimento fundador, que supostamente inaugura uma nova era (o nascimento de Cristo ou do Buda, a Hégira, ascensão de um determinado soberano,etc.), determina o momento axial em relação ao qual todos os outros eventos são datados. Esse momento axial é o marco zero para a contagem do tempo cronológico. (RICOUER, 2010, p. 181)
}

Frederic Jameson (2007, p. 189) considera que "a forma narrativa desse evento primordial ou axial deve estar presente, ou ser recriada, no romance histórico para que ele se torne histórico no sentido genérico". Nesse sentido, os dois eventos anteriormente mencionados são o marco zero da história da formação do Rio Grande do Sul e da constituição da família Terra-Cambará, e "A fonte", título do capítulo que abarca esses dois eventos, é uma metáfora tanto de um quanto de outro.

Da mesma forma, no final da obra também o destino da família está entrelaçado ao momento histórico do Brasil. A saga familiar que começa com o nascimento de Pedro Missioneiro e a incorporação dos Sete Povos ao território português, dando origem ao Rio 
Grande do Sul, termina com a morte do patriarca Rodrigo Terra Cambará e com o fim do Estado Novo, através da deposição de Getúlio Vargas após 15 anos à frente da presidência da República do Brasil. De um ponto ao outro, são 200 anos de História, nos quais há um desenvolvimento contínuo da família, do estado e do país.

O final também remete a um recomeço, tanto no plano da estrutura narrativa pelo fato de ela ser metaficcional e ser finalizada pelas mesmas palavras que a iniciam, conforme veremos no item sobre a metaficção; quanto no plano do conteúdo, pois a morte de Rodrigo acaba por fragmentar a família Terra-Cambará. Os seus filhos Floriano, Jango, Eduardo e Bibi possuem visões de mundo e interesses muito diferentes, muitos deles até incompatíveis, de forma que cai por terra a união que existia entre os integrantes da família até a geração de Rodrigo, fragmentando-a totalmente, conforme podemos verificar no trecho abaixo, em que Floriano conta ao seu amigo Roque Bandeira a discussão ocorrida durante o café da manhã por causa do inventário dos bens deixados pelo pai:

Floriano contou o incidente desagradável ocorrido no sobrado naquela manhã. Depois de muitos rodeios, em que usara toda sua lábia, Sandoval tocara no assunto melindroso de inventário. Achava que se devia tratar dele sem tardança, pois Bibi estava ansiosa por voltar para o Rio. Jango fechou a cara, mas Eduardo declarou: "Acho bom mesmo resolver logo esse negócio, porque eu tenho cá os meus planos".

- Três das quatro mulheres presentes a esse conselho de família - disse Floriano - mantiveram um silêncio digno. Bibi naturalmente apoiou o marido em toda a linha. Eu me desinteressei do assunto, confesso que encabulado.. Fiquei pensando em outras coisas e, quando dei acordo de mim, estava travada uma discussão violenta entre o Eduardo e o Jango...

- Imagino o que possa ter sido - murmurou Bandeira.

- O pomo da discórdia naturalmente foi o Angico. O Jango propôs arrendar a parte do campo que vai caber a cada herdeiro, para que as coisas na estância possam continuar como estão. Mas o Eduardo não concordou; "A minha parte eu não arrendo. Vou transformá-la numa granja piloto". O Jango saltou como um tigre. "Estás louco? Dividir a nossa terra? É ridículo! Que é que entendes de granjas e estâncias?"A coisa se esquentou de tal maneira, que lá pelas tantas eu me levantei e gritei: "Calem a boca! Respeitem ao menos as mulheres. Discutam isso com bom senso e não como dois idiotas". (VERISSIMO, 1995g, p. 1024) 
No plano histórico-nacional, o recomeço é político através da redemocratização do país.

Nesses 200 anos em que história fictícia da família Terra-Cambará se entrelaça e se confunde com a História do Estado do Rio Grande do Sul e do Brasil, todos os acontecimentos históricos importantes são filtrados e vistos pela ótica de pessoas da família ou então de pessoas muito próximas a elas, como o padre Lara, pároco de Santa Fé, e o Dr. Carl Winter, médico da cidade e da família, o que permite ao autor realizar uma releitura crítica da história, conforme estava previsto no projeto de escrita da obra, procurando desmitificar muitos aspectos da história do Rio Grande do Sul.

A princípio, a forma de representação literária que Erico Verissimo se utiliza em $O$ tempo e o vento para realizar o diálogo entre ficção e história é característica do romance histórico tradicional, conforme a teorização feita por Georg Lukács (1966), pois o escritor traça um grande painel histórico, valendo-se de um narrador em terceira pessoa para simular distanciamento e imparcialidade e de personagens fictícias na análise dos acontecimentos históricos abordados, enquanto que as personagens históricas são apenas citadas na narrativa.

Nesse sentido, Erico Verissimo representa literariamente como as pessoas que viveram no Rio Grande do Sul entre 1745 e 1945 foram afetadas pelos acontecimentos históricos do período e como reagiram a eles, através do entrelaçamento entre história e ficção, conforme a visão aristotélica do que foi (o fato histórico) e do que poderia ter sido (a reação das pessoas/ personagens) (ARISTÓTELES, 1998). Sob esse aspecto, o trecho abaixo que descreve como a família Terra e as outras famílias do então povoado de Santa Fé foram afetadas pela Guerra da Cisplatina é exemplar:

Tudo corria bem para os Terras quando começaram a circular rumores duma nova guerra. Dizia-se que D. João resolvera tomar conta da Banda Oriental. Ana Terra suspirou e disse:

- Isso é falta de serviço. Se esse homem tivesse de trabalhar como a gente, de sol a sol, não ia se lembrar de invadir terra alheia. 
Foi no ano de1811. Contava-se que na Banda Oriental havia barulho, porque os platinos queriam se ver livres da Espanha. Quem é que ia entender aquela confusão? Diziam também que D. Diogo de Souza, o comandante das forças portuguesas na Capitania do Rio Grande, estava acampado em Bagé com seus exércitos. Tudo indicava que estava preparando a invasão.

Arminda rezava dia e noite diante do Cristo sem nariz. As mulheres de Santa Fé encheram a capela no dia em que se confirmaram os boatos de guerra. $\mathrm{E}$ lá dentro o rumor das rezas se misturava como o do choro.

Quando Chico Amaral apareceu uma tarde, exaltado, em cima do seu cavalo e mandou tocar sino, chamando os habitantes do lugar, Ana Terra saiu com um frio da alma, porque sabia o que ia acontecer. E tudo aconteceu como ela temia. D. Diogo de Souza apelava para o Maj. Francisco Amaral, pedindolhe que se reunisse o quanto antes com seus homens às forças portuguesas que iam invadir a Banda Oriental.

Pedro teve de abandonar a lavoura para se incorporar à tropa de Chico Amaral. (VERISSIMO, 1995h, p. 151)

Ao mostrar a maneira como os membros da família Terra (Ana, Pedro e Arminda) e todos os santafezenses foram atingidos pela Guerra da Cisplatina e as consequências que ela teve na vida social e econômica do município, o escritor realiza a intersecção entre os acontecimentos históricos e as existências individuais agrupadas em sociedade (JAMESON, 2007), conforme a teoria lukcasiana de que o romance histórico deve representar

as grandes transformações da história como transformações da vida do povo. Seu ponto de partida está sempre na apresentação das influências na vida cotidiana do povo por parte das importantes modificações históricas, e na apresentação das modificações materiais e psíquicas provocadas por elas nos seres humanos que, sem dar-se conta de suas causas, reagem sem embargo a elas de forma imediata e veemente. Partindo dessa base, elabora as complicadas correntes ideológicas, políticas e morais que por força surgem nessas transformações. (LUKÁCS, 1966, p. 52-53)

Desse modo, a forma de representação literária utilizada em $O$ tempo e o vento comunga a ideia lukacsiana (LUKÁCS, 1966) de que há uma história e ela é um processo ininterrupto de mudanças que intervêm diretamente na vida das pessoas, e por essa razão o romance histórico deve enfatizar as figuras humanas e não os acontecimentos históricos, principalmente, conforme observa Regina Zilberman (2003, p. 120), quando elas "se organizam em grupos domésticos". Nesse sentido, a professora complementa: 
São, pois, os pilares do romance histórico: a época representada, que coincide com um período de crise e mudança; e, acima da época, a presença de seres humanos que vivenciam, nas suas existências, mesmo quando deslocados dos grandes centros de poder, as consequências das alterações por que passa o período. (ZILBERMAN, 2003, p. 121)

No entanto, ao inscrever fatos históricos em $O$ tempo e o vento, mostrando como as figuras humanas fictícias os teriam vivenciados e como eles interferiram na vida delas, ressuscitando assim a singularidade histórica da época representada, Erico Verissimo nem sempre o faz para legitimá-los ou para conferir veracidade à narrativa, e muitas vezes os utiliza para questioná-los através do contraponto que ele estabelece com outras histórias "que não entraram nos livros escolares" (YOUNG, 1997, p. 102), realizado por meio da técnica do contraponto e da polifonia. Aliás, o escritor deixa bem claro a sua desconfiança em relação à história oficial num trecho do romance em que o padre Lara, pároco de Santa Fé, ao dar notícias a Bibiana sobre o andamento da Guerra dos Farrapos, faz a seguinte reflexão:

Não deixava de ser curioso a gente ver a História no momento em que ela estava sendo feita! Dali a cem anos, como iriam os historiadores descrever aquela guerra civil? O Pe. Lara sabia como era custoso obter informações certas. As pessoas dificilmente contavam as coisas direito. Mentiam por vício, por prazer ou então alteravam fatos por causa de suas paixões. Cenas da vida cotidiana que se tinham passado sob o seu nariz, ali mesmo na praça de Santa Fé, eram depois relatadas na venda do Nicolau duma maneira completamente diferente. Como era então que a gente podia ter confiança na História? Passou-lhe, então, pela mente a lembrança da importância que tinha para a Igreja Católica a tradição oral... Ora estava claro que com a Igreja, que era divina, a coisa era diferente. Mas seria mesmo diferente? Essa dúvida era indigna dum sacerdote. Que Deus lhe perdoasse a heresia! (VERISSIMO, 1995h, p. 296-297)

Nesse aspecto, ao questionar a história oficial, propondo-se a desmitificá-la através da realização de uma releitura crítica, conforme previa o projeto de escrita da saga do Rio Grande do Sul, O tempo e o vento se diferencia do romance histórico tradicional por conta desse caráter engajado e se aproxima do novo romance histórico latino-americano, conforme acepção de Fernando Ainsa (1991), por apresentar algumas de suas principais características, 
como as que seguem citadas abaixo, segundo transcrição feita por Antonio Roberto Esteves do texto de Ainsa:

1 - O novo romance histórico caracteriza-se por fazer uma releitura crítica da história;

2 - A releitura proposta por esse romance impugna a legitimação instaurada pelas versões oficiais da história. Nesse sentido a literatura visa suprir as deficiências da historiografia tradicional, conservadora e preconceituosa, dando voz a tudo aquilo que foi negado, silenciado ou perseguido pela história;

3 - A multiplicidade de perspectivas possíveis faz com que não haja uma só verdade do fato histórico. A ficção confronta diferentes versões que podem ser até mesmo contraditórias;

4 - O novo romance histórico aboliu aquilo que Bakhtin chama de "distância épica do romance" histórico tradicional, eliminando a alteridade do acontecimento inerente à história como disciplina. $\mathrm{O}$ romance, por sua própria natureza aberta, livre e integradora, permite uma aproximação ao passado numa atitude verdadeiramente dialogante e niveladora;

5 - Ao mesmo tempo em que se aproxima do acontecimento real, o novo romance histórico se distancia de forma deliberada e consciente da historiografia oficial, cujos mitos fundacionais estão degradados;

6 - Há, nesse romance histórico, uma superposição de tempos históricos diferentes. Sobre o tempo romanesco, presente histórico da narração, incidem os demais;

(...) (ESTEVES, 1995, p. 29-30)

Dessa forma, para realizar a releitura crítica da história do Rio Grande do Sul com o objetivo de desmitificá-la, além da saga familiar que lhe serve de fio condutor, Erico Verissimo vai se valer da utilização de duas técnicas narrativas que lhe são complementares, o contraponto e a polifonia, que permitem ao escritor questionar determinados aspectos da história gaúcha, como o caráter nobre da guerra e o mito da democracia racial gaúcha, e ainda inserir na narrativa uma antissaga da família Terra-Cambará, através da história dos pobres e miseráveis Carés. 


\subsubsection{A técnica narrativa do contraponto}

Em O tempo e o vento, a técnica narrativa do contraponto é utilizada de duas maneiras distintas e também com objetivos diferentes:

1) para a articulação da história que se passa no sobrado, no tempo diacrônico, com as diversas histórias dos integrantes da família Terra-Cambará, passadas no tempo sincrônico. Essa utilização permite ao autor elaborar a narrativa com dois tempos históricos distintos, de forma a quebrar a linearidade da narrativa, sem, contudo, prejudicar a sua comunicabilidade.

2) e para a inserção de outras histórias que ficaram à margem da narrativa principal nos episódios intermediários presentes em $O$ continente e $O$ arquipélago, como, por exemplo a história da família Caré, que representa uma espécie de antissaga familiar. A utilização desse recurso permite ao autor inserir na narrativa a história dos excluídos, dos gaúchos pobres e sem história, que ficaram à margem da história oficial.

\subsubsection{O contraponto e a intercalação de dois níveis temporais}

Através da técnica narrativa do contraponto, Erico Verissimo estruturou $O$ tempo e o vento com dois tempos históricos distintos, um diacrônico e o outro sincrônico, nos quais são ambientadas as várias histórias da família Terra-Cambará, num período de 200 anos. Valendo-se do processo de alternância, o narrador intercala essas histórias que se passam em tempos históricos diferentes.

As histórias pertencentes ao tempo sincrônico são ambientadas durante três dias de junho de 1895 , em $O$ continente, e nos meses de novembro e dezembro de 1945 , em $O$ retrato e $O$ arquipélago; enquanto que as histórias do tempo diacrônico reconstituem a saga 
da família Terra-Cambará de 1745 a 1943. Intercalados entre essas histórias, há em $O$ continente e $O$ arquipélago alguns pequenos capítulos intermediários, os interlúdios, escritos em forma de poema.

$O$ continente, primeiro romance da trilogia, aborda um período histórico de 150 anos (de 1745 a 1895) e é formado por três tipos diferentes de capítulos:

1 - Os capítulos da série "O sobrado", que vão de I a VII, correspondem ao nível temporal sincrônico e narram os três dias do cerco ao sobrado da família Terra-Cambará durante na Revolução Federalista, de 25 a 27 de junho de 1895. Nesses três dias, Licurgo Cambará, a mãe (Bibiana), o sogro (Florêncio), a cunhada (Maria Valéria), a esposa (Alice), e os filhos (Toríbio e Rodrigo) estão sitiados no casarão, praticamente sem água e sem comida, e com Alice em trabalho de parto.

2 - Os capítulos “A fonte”, “Ana Terra”, “Um certo capitão Rodrigo”, "A teiniágua”, "A guerra" e "Ismália Caré" correspondem ao nível temporal diacrônico e narram a história da família Terra-Cambará, desde a origem até alguns anos antes do cerco ao sobrado. Intercalados aos capítulos de "O sobrado", eles são responsáveis pela sequência cronológica do vasto período histórico abordado no romance, desde 1745 até o início da década de 90 do século XIX.

3 - Intercalados entre os capítulos que envolvem dois níveis temporais distintos, há seis pequenos capítulos, sem título, que preenchem determinadas lacunas do texto e dá voz a determinadas camadas sociais até então excluídas da narrativa. Segundo Regina Zilberman (2004), esses episódios têm como função referir-se aos acontecimentos históricos intermediários, oportunizar a emergência de uma personagem coletiva que sofreu os efeitos das inúmeras guerras e conflitos armados ocorridos na província do Rio Grande do Sul, e narrar a trajetória da família Caré, que tem papel periférico e ocupa um lugar marginal no romance. 
O segundo romance da trilogia, $O$ retrato, que aborda um período histórico de 1909 a 1945 e concentra-se, principalmente, na figura do Dr. Rodrigo Terra Cambará, tem uma estrutura um pouco diferente da utilizada em $O$ continente. Erico Verissimo organiza os dois volumes do romance em apenas quatro capítulos, eliminando os interlúdios. No entanto, ele mantém a utilização dos dois níveis temporais, de forma que o primeiro capítulo, "Rosa dos Ventos", e o último, "Uma vela pro negrinho", pertencem ao nível sincrônico e são ambientados no mês de novembro de 1945, quando toda a família Terra-Cambará está reunida no sobrado, após o Dr. Rodrigo sofrer um infarto e retornar a Santa Fé depois de viver quinze anos no Rio de Janeiro, onde era um dos homens de confiança do presidente Getúlio Vargas. Os outros dois capítulos, "Chantecler” e "A sombra do anjo”, pertencem ao nível diacrônico e reconstituem a história da família e a trajetória de Rodrigo. Nesses romances surgem novas personagens na trilogia: Flora (esposa de Rodrigo), Floriano, Alicinha, Eduardo, Jango e Bibi (filhos de Rodrigo e Flora); Silvia, Arão Stein, Roque Bandeira, Neco Rosa, Chiru Mena e Zeca, entre os mais importantes.

$O$ retrato encerra a abordagem do tempo diacrônico em 1915 e o romance seguinte, $O$ arquipélago, vai dar sequência a ela a partir de 1922, através dos capítulos “O deputado", "Lenço encarnado", "Um certo major Toríbio", 'O cavalo e o obelisco", "Noite de ano bom" e "Do diário de Silvia", que vão reconstituir a trajetória da família Terra-Cambará, principalmente de Rodrigo, juntamente com a abordagem dos acontecimentos históricos que balançaram as estruturas do Rio Grande do Sul e do Brasil no período: a Revolução gaúcha de 1923, a Revolução de 30 e o Estado Novo, nos quais Rodrigo é participante ativo.

Nesse terceiro e último romance da trilogia, estruturado em três volumes, os capítulos intitulados "Reunião de família", que vão do I ao VI, juntos com o capítulo final, "Encruzilhada", são ambientados nos meses de novembro e dezembro de 1945 e pertencem ao nível temporal sincrônico. Nesses capítulos, predominam a abordagem do drama familiar em 
torno da doença de Rodrigo Cambará, a discussão da política nacional após a queda de Getúlio Vargas e as conversas e reflexões realizadas entre Floriano e seu amigo Roque Bandeira sobre o romance que o primeiro está planejando escrever.

Em $O$ arquipélago, Erico Verissimo volta a utilizar os capítulos intermediários, os interlúdios, dessa vez denominados de "Caderno de pauta simples", uma espécie de diário escrito em prosa e verso, contendo as reflexões de Floriano sobre o projeto da escrita do seu romance e suas lembranças da infância e do tempo vivido nos Estados Unidos.

Dessa forma, o contraponto se dá através do diálogo entre as histórias dos dois tempos históricos distintos e entre elas e os capítulos intermediários, sendo que a ligação entre os dois níveis temporais predominantes é realizada através da utilização da analepse, que é a evocação de um acontecimento anterior ao ponto da história em que se está, ou da prolepse, que, ao contrário, consiste em antecipar um acontecimento posterior, conforme a teoria narrativa de Gérard Genette (1976, p. 38). Em muitas dessas passagens, o narrador utiliza alguns liames para fazer a interlação, como, por exemplo, no final de “O sobrado II" em $O$ continente, a anciã Bibiana Terra Cambará, sentada em sua cadeira de balanço, ao ouvir o barulho do vento soprando nas vidraças, diz para si mesma: “- Bem dizia a minha avó resmunga D. Bibiana, cerrando os olhos - Noite de vento, noite dos mortos" (VERISSIMO, 1995h, p. 72). As palavras de Bibiana encerram o capítulo e na página seguinte inicia-se o segundo capítulo diacrônico (Ana Terra), com uma digressão temporal para narrar história da matriarca Ana Terra: "Sempre que me acontece alguma coisa importante, está ventando" costumava dizer Ana Terra" (VERISSIMO, 1995h, p. 73). E ao encerrar o capítulo "Ana Terra", o narrador vai se valer da prolepse para retomar a fala de Bibiana que serviu de elemento de ligação para a regressão que permitiu narrar a história da avó:

E quando um novo inverno chegou e o minuano começou a soprar, ela o recebeu como um velho amigo resmungão que gemendo cruzava por seu rancho sem parar e seguia campo afora. Ana Terra estava de tal maneira habituada ao vento que até parecia entender o que ele dizia. E nas noites de 
ventania ela pensava principalmente em sepulturas e naqueles que tinham ido para o outro mundo. Era como se eles chegassem um por um e ficassem ao redor, contando casos e perguntando pelos vivos. Era por isso que muito mais tarde, sendo já mulher feita, Bibiana ouvia a avó dizer quando ventava: "Noite de vento noite dos mortos..." (VERISSIMO, 1995h, p. 152)

Por conta da sua estrutura narrativa formada pelo diálogo constante entre dois tempos históricos, a trilogia adquire também duas características no novo romance histórico latinoamericano, conforme a acepção de Fernando Ainsa:

4 - O novo romance histórico aboliu aquilo que Bakhtin chama de "distância épica do romance" histórico tradicional, eliminando a alteridade do acontecimento inerente à história como disciplina. $\mathrm{O}$ romance, por sua própria natureza aberta, livre e integradora, permite uma aproximação ao passado numa atitude verdadeiramente dialogante e niveladora;

(...)

6 - Há nesse romance histórico, uma superposição de tempos históricos diferentes. Sobre o tempo romanesco, presente histórico da narração, incidem os demais;

(...) (ESTEVES, 1995, p. 29-30)

Desse modo, através da técnica do contraponto, Erico Verissimo consegue com rara habilidade articular a longa narrativa (mais de 2.200 páginas) com dois tempos históricos, de modo que os três romances que formam a trilogia são estruturados a partir de avanços e recuos temporais, sem que isso prejudique a comunicabilidade da obra e a sua qualidade estética. A utilização desse recurso narrativo que possibilita o jogo de simultaneidade temporal, permite, conforme bem observou Regina Zilbeman (2004), que se compreenda uma história à luz da outra, sem que nenhuma delas perca a sua unidade e autonomia, até que ambas se aproximem e se confundam com a dissolução do tempo diacrônico no sincrônico. 


\subsubsection{A família Caré como contraponto à família Terra-Cambará e à história oficial}

Através da técnica do contraponto, Erico Verissimo insere na narrativa a história da família Caré em contraposição à história oficial e à saga da família Terra-Cambará. Os Caré são uma família de gaúchos paupérrimos, explorados pelas classes superiores e pelo estado, e representam na trilogia todos aqueles que foram deixados à margem pela história oficial e que sofreram mais do que outros os efeitos das inúmeras guerras e conflitos armados ocorridos no Rio Grande do Sul. Ao contrário dos Terra-Cambará que possuem uma vida modesta e depois ascendem socialmente e economicamente, os Caré estão abaixo da linha de pobreza e permanecem miseráveis e discriminados até o final da trilogia, embora um de seus membros, o cabo Lauro Caré, tenha chegado à condição de herói morto em solo italiano durante a Segunda Guerra Mundial e por isso tenha recebido uma estátua na praça de Santa Fé.

A saga dos Caré é narrada, principalmente, nos interlúdios de $O$ continente, pequenos capítulos intercalados entre os capítulos principais, que além de narrar a história da família marginal também preenchem determinadas lacunas históricas. Segundo Regina Zilberman (2004), essa narrativa intermediária desempenha uma dupla função:

a) faz a colagem cronológica entre os episódios, preenchendo as lacunas entre cada período histórico narrado pelo ficcionista e o seguinte; assim, após "A fonte", que mostra a formação do Rio Grande do Sul em meio às guerras missioneiras, são relatados outros eventos da ocupação do território; após "Um certo capitão Rodrigo", a Guerra Farroupilha; e assim sucessivamente;

b) apresenta a perspectiva popular, que igualmente carrega dupla face: o narrador expressa a voz populi, quando avalia os malefícios causados pela guerra e as perdas sofridas pela família (...) E conta a história das classes populares, sumariadas na família Caré, que ocupa a linha inferior da composição social sul-rio-grandense. (ZILBERMAN, 2004, p. 157)

O narrador ao apresentar o primeiro Caré faz a apresentação através do olhar de um estrangeiro, um botânico francês em viagem pelas terras gaúchas, e por meio dele faz uma contestação direta da historiografia oficial que só via importância histórica nos altos oficiais e 
estancieiros, deixando à margem da história os pobres, os índios, os negros e todo tipo de marginais que contribuíram para a formação da sociedade sul-riograndense e não têm essa contribuição reconhecida. Nesse sentido, pela voz do estrangeiro, o narrador faz uma reflexão sobre o fato dos habitantes da capitania não admitirem que uma pessoa simples e honesta, sem galões militares, títulos de nobreza ou léguas de terra, possa ter alguma importância, e elenca vários tipos de gaúchos anônimos, miseráveis e excluídos até chegar em João Caré e, de forma implícita, nomeá-lo representante de todos os deserdados pela história gaúcha:

Noite de abril. À luz duma vela, na casa onde se hospeda, o botânico francês toma uma nota em seu diário de viagem.

Observo que quanto mais simplicidade de maneiras e conversa imprimo a meus atos, menos deferência recebo.

Os habitantes da Capitania do Rio Grande estão de tal modo habituados ao militarismo e ao ar carrancudo dos oficiais, que não acreditam em que uma pessoa simples e honesta possa ter importância.

Sim, os homens que tinham galões, títulos de nobreza, léguas de sesmaria, botas e cavalos falavam alto e grosso, de cabeça erguida.

E havia também os sem títulos nem terras nem galões, que falavam grosso e de cabeça erguida porque tinham armas, botas e cavalos.

Mas os gaúchos sem cavalo, sem botas, sem nada; os pobres-diabos que andavam molambentos e de mãos vazias, esses só falavam alto e grosso entre os de sua igualha.

Por que ante os bem montados ficavam de olhos baixos e sem voz.

De seu às vezes nem um nome tinham. Donde vinham? Ninguém sabia ao certo nem procurava saber. Alguns tinham nascido de chinas ou bugras que dormiram com tropeiros, ladrões de gado, carreteiros, buscadores de ouro e prata, preadores de índios.

Outros eram sobras de antigas bandeiras,

retirantes da Colônia de Sacramento,

escravos foragidos,

desertores do Regimento de Dragões,

castelhanos vindos do outro lado do Uruguai, das planuras platinas: gente andarenga sem pouso certo,

mamelucos, curibocas, cafuzos, portugueses, espanhóis.

Alguns carregavam fêmeas e crias, mas em geral andavam sozinhos.

E eram mais miseráveis que os bugres.

Ali vai um desses.

Como é o seu nome?

João Caré. (VERISSSIMO, 1995h, p. 153-154)

Dessa forma, Erico Verissimo nos mostra um outro lado da história da formação do estado e da sociedade gaúcha, aquela face oculta, não revelada nos livros escolares, formada 
pela mistura de diversos tipos sociais e grupos étnicos: prostitutas, ladrões de gado, tropeiros, carreteiros, garimpeiros, preadores de índios, retirantes, escravos foragidos, desertores do exército, andarilhos, índios, negros, portugueses, espanhóis, platinos, mamelucos, curibocas e cafuzos. Desse modo, Erico Verissimo elege a miscigenação como o elemento condutor da formação da sociedade e do estado gaúcho, não descartando a contribuição de nenhum grupo étnico nesse processo, embora, durante a narrativa, de forma alguma tente esconder o caráter violento do processo de colonização e as tensões existentes entre os grupos étnicos.

Embora Erico Verissimo não seja um escritor pós-moderno, podemos ver a presença desses grupos marginais representados pelos Caré, que vivem fora do centro da narrativa ocupado pela família Terra-Cambará, como uma característica da pós-modernidade, podendo ser considerados como grupos ex-cêntricos, no sentido definido por Linda Hutcheon (1991, p.89) como "grupos anteriormente silenciosos definidos por diferenças de raça, sexo, preferências sexuais, identidade étnica, status pátrio e classe", que a partir dos anos 60 passam a ser registrados na história. Nesse sentido, ao fazer uma releitura crítica da história da formação do Rio Grande Sul, revelando grupos marginalizados e vozes silenciadas pela história, a narrativa, que é construída a partir de um modelo de representação literária característica do romance histórico tradicional, passa a ter também características do novo romance histórico latino-americano, que são a releitura crítica da história com o propósito de impugnar a legitimação instaurada pela história oficial (AINSA, 1991).

A história dos Caré como representantes dos excluídos do processo histórico, narrada nos interlúdios, é uma anti-história tanto em relação à história oficial quanto em relação à saga dos Terra-Cambará. No trecho abaixo, é nítida a distinção estabelecida entre o capitão Rodrigo Cambará e Pedro Caré pela participação de ambos na Guerra da Cisplatina. O primeiro é descrito como personagem ativo da história, com direito à promoção pelos atos 
heroicos, e o segundo como um anônimo, que nem sequer sabia ao certo por que e contra quem brigavam, e não tinha direito a nada, nem mesmo ao soldo.

\footnotetext{
Depois veio a guerra com os castelhanos. Formaram nas colônias uma Companhia de Voluntários Alemães.

E de vários pontos da Província cinco Carés foram levados a maneador para as tropas nacionais como voluntários.

Nunca ficaram sabendo direito contra quem brigavam nem por quê.

Mas lutaram como homens, e nenhum deles desertou. Eram magros mas rijos.

Foi nessa mesma guerra que um tal Tte. Rodrigo Cambará um dia avançou a cavalo contra uma bateria castelhana e com um laço de onze braças laçou uma boca de fogo inimiga e se precipitou com ela gritando e rindo, a trancos e barrancos, para as linhas brasileiras.

Por essa e por outras ganhou uma medalha e foi promovido a capitão.

Pedro Caré nessa guerra teve um braço amputado. E nunca recebeu soldo. (VERISSSIMO, 1995h, p. 157)
}

Mas, mesmo sem reconhecimento e sem recompensa, Erico Verissimo vê esses homens miseráveis e anônimos, deserdados pela história, como verdadeiros heróis. Pessoas que não sucumbem diante da miséria e do preconceito e que apesar de todas as adversidades ainda mantêm o otimismo diante da vida e por isso persistem em sobreviver.

Quando veio a paz voltou à vida antiga.

Onde foi que perdeu o braço?

Na guerra.

Não lhe faz muita falta?

Nem tanto. Graças a Deus me cortaram só um braço.

E meio rindo ele mostrava sua china, que tinha um filho no colo e outro na barriga.

Por essa e por outras foi que a raça dos Carés continuou. (VERISSSIMO, 1995h, p. 157)

Outros Caré surgem na narrativa (Mingote, Lulu e José Caré) até chegar em Chiru Caré, que fixa residência no Angico, estância dos Terra-Cambará. A partir da fixação da família de Chiru no Angico, o destino deles passa a se cruzar com os membros da família Terra-Cambará e deixam os interlúdios para figurar nos capítulos do tempo diacrônico e nos capítulos do tempo sincrônico. Mas nem por isso deixam de ocupar um papel marginal na narrativa, continuando a servir de contraponto à história da família protagonista e à história 
oficial, como representantes do "ângulo popular da formação do Rio Grande do Sul" (ZILBERMAN, 2004, p.30).

Dessa forma, o sexto capítulo de $O$ continente intitula-se "Ismália Caré", nome da filha de Mané Caré que se torna amante de Licurgo Cambará. Por essa razão, o papel de protagonista que ela aparentemente ocupa é, na verdade, um papel secundário. Ela é poucas vezes citada num capítulo que possui quase 100 páginas, e quando isso acontece é para comentar ou refletir sobre o seu papel subalterno, devido à sua baixa condição social, inclusive, as principais reflexões preconceituosas vêm do próprio Licurgo, embora ele dê amostras de amá-la realmente. Licurgo, ao ser pressionado pela avó para deixar a amante, em razão do seu casamento que se realizaria dali a um mês, chega à conclusão de que jamais conseguiria abandonar Ismália. No entanto, se refere a ela de maneira preconceituosa, como um animal de estimação sempre à disposição do dono, conforme podemos observar no trecho abaixo:

Seria inútil explicar à avó que ele gostava da prima Alice o suficiente para
fazê-la feliz; que a achava bonitinha, prendada, e que tinha a certeza de que
ela ia ser ótima dona de casa, boa esposa e boa mãe - mas que todas essas
coisas nada tinham a ver com o que ele sentia pela Ismália. A chinoca não
pedia nada, não esperava coisa alguma. Gostava dele quase como uma
cadelinha gosta do dono. Se por um lado ele sabia que não teria nunca a
coragem de abandonar a amante, por outro também estava certo de que seu
rabicho pela Ismália nunca, mas nunca mesmo, poderia influir e sua afeição
pela prima nem perturbar-lhe a paz do casamento. (VERISSIMO, 1995h, p.
566-567)

Licurgo segue rigorosamente o código patriarcal. Para ele, o casamento é acima de tudo uma obrigação social, em que a esposa tem o papel de cuidar da casa, procriar e cuidar dos filhos e por isso deve ser realizado com uma mulher de boa família e da mesma classe social, características que aos olhos dele Ismália não possui, haja vista o conceito que ele tem da família dela: "Nunca pudera compreender como duma família de posteiros miseráveis e 
molambentos havia nascido uma criatura bonita como a Ismália, com traços mais finos que o de muita filha de estancieiro rico." (VERISSIMO, 1995h, p. 643)

Embora sendo muito bonita, ela pertence a uma família de miseráveis e por isso jamais poderia ocupar o papel de esposa dele. Nessas condições, o único papel possível para ela ocupar é o de amante, coisa que Licurgo não abre mão, pois, na sua concepção, o fato de estar casado com Alice não invalida a busca do prazer e do amor fora de casa, e assim as duas coisas não se anulavam e eram perfeitamente compatíveis entre si. Dessa forma, conforme observa Lélia Almeida (1996, p. 60), "o espaço do casamento é o espaço da afeição suficiente para conviver num lar com filhos, e o espaço do desejo, da sexualidade, na contra-mão do primeiro, é reservado à Ismália, a outra".

Nesse sentido, sobre o papel marginal ocupado pelos Caré e também sobre a situação ingrata de Ismália, Maria da Glória Bordini observa que eles são dignificados na narrativa através da solidariedade expressada pelo narrador.

Erico trata a representação desses deserdados da fortuna apenas como uma massa coletiva, sem direito à individualização, ao longo de todo $O$ continente, mas quando sua trajetória avança para o final, concede à Ismália o papel de verdadeiro objeto do amor de Licurgo, o que desligitima o casamento de aristocratas rurais que esse mantinha a duras penas com Alice. Os Caré, apesar de sua impotência e da sorte infausta a que se destina Ismália, são dignificados no modo de funcionamento que a narrativa lhes concede. Anônimos, peças decorativas do cenário em que se movem os Terra-Camará e seus adversários, têm sua dor silenciosa expressa no discurso lírico do narrador que os contempla também doloridamente. Sem poderem participar das várias histórias que se desenrolam no texto, pontuamno, porém, com sua presença muda e eloquententemente denunciadora das injustiças daqueles que os usam e os descartam como gado. (BORDINI, 2004, p.79-80)

No entanto, um dos Caré vai ter um pequeno reconhecimento pela população de Santa Fé no final da trilogia: o cabo Lauro Caré, neto de Licurgo e Ismália, morre em solo italiano durante a Segunda Guerra Mundial e recebe um busto na praça da cidade. Essa homenagem soa como uma espécie de recompensa do autor pelo esquecimento histórico dos Caré que 
lutaram heroicamente nas Guerras da Cisplatina, dos Farrapos e do Paraguai, e nas Revoluções de 93, 23 e 30; mas também se passa a impressão de que o reconhecimento do cabo como herói só se deu pelo fato de ser do conhecimento público que ele tinha sangue de uma das mais tradicionais famílias da cidade. Dessa forma, por ter sangue Cambará, ele estava um pouco acima do nível dos seus iguais. Nesse sentido, é significativo o comentário de Aderbal Quadros, sogro de Rodrigo Cambará, sobre o heroísmo do cabo Caré: "Os Carés sempre pelearam em campo aberto, mas esse menino teve de brigar em montanha, como cabrito. Mas brigou lindo, como homem. Sangue não nega. Cambará misturado com Caré só podia dar isso..." (VERISSIMO, 1995g, p. 583)

No entanto, sem tirar o mérito do reconhecimento do ato heroico de Lauro Caré, o acontecimento é visto com ressalvas por Floriano, Roque Bandeira e Eduardo. Floriano pensa no absurdo e na gratuidade da guerra e se questiona "Não seria preferível que ele estivesse vivo, em Santa Fé, a manejar o seu torno e exercer o seu artesanato?" (Ibid., p. 570); Roque Bandeira faz um comentário em forma de pergunta: "- Não é mesmo estranho que esse piá, que pouco ou nada sabia de Geografia ou História, acabasse morrendo na Itália, numa guerra que decerto nunca chegou a compreender direito?" (Ibid., p. 595) E Eduardo responde à pergunta de Bandeira com um comentário que pode muito bem resumir toda a trajetória da família Caré, bem como tirar um pouco da nobreza do reconhecimento feito pela sociedade de Santa Fé: "- O destino dos Carés - glosa Eduardo - foi sempre lutar na guerra dos outros, sem nenhum proveito para o seu clã. Esse bem podia ser também um monumento ao Alienado Social" (Ibid., p. 596). 


\subsubsection{A polifonia}

Em O tempo e o vento a polifonia surge nos episódios intermediários de $O$ continente, constituídos por várias vozes anônimas, e, principalmente, nos diálogos travados entre as personagens, através do contraste das suas ideias divergentes, como acontece, por exemplo, nos diálogos entre a voz masculina e a feminina em relação à guerra e nos pensamentos de Licurgo Cambará sobre a condição do negro, que contrastam com as suas palavras e atitudes. $^{11}$

\subsubsection{A desmitificação da guerra}

Através da técnica narrativa da polifonia, articulada pelo narrador por meio de diálogos e da exposição do pensamento das personagens, Erico Verissimo insere na narrativa de $O$ tempo e o vento algumas vozes silenciadas pela história que podem dar outras versões dos fatos históricos e assim contar uma outra história dentro da mesma história.

Isso ocorre, principalmente, com a voz feminina que numa sociedade patriarcal, como era sociedade gaúcha no tempo histórico abordado, não tinha o direito de expressar a sua opinião sobre assuntos que diziam respeito aos homens, como a guerra, por exemplo, que é um dos motores da história do Rio Grande do Sul. Dessa forma, ao narrar a saga da família Terra-Cambará, associada à história gaúcha e brasileira, Erico Verissimo vai estabelecer um contraponto entre a voz masculina e a voz feminina: a primeira vai se guiar pelo código

\footnotetext{
${ }^{11} \mathrm{Em} O$ tempo e o vento a polifonia também é realizada por meio da utilização de diferentes narradores. Em $O$ arquipélago, os capítulos intermediários "Caderno de pauta simples" são narrados em primeira pessoa pela voz do escritor Floriano Cambará, o mesmo acontecendo com o capítulo "Do diário de Silvia", narrado pela dona do diário.
} 
patriarcal gaúcho e enaltecer o heroísmo e a grandiosidade dos feitos guerreiros e a segunda vai contestar o caráter nobre desses feitos, inserindo no tecido narrativo um outro lado dos conflitos violentos pelos quais passaram os habitantes do estado, denunciando todo o horror e a violência disseminados pelas guerras e assim o escritor desmitifica, através da voz feminina um dos elementos mais importantes da história gaúcha: o caráter heroico da guerra.

Ao dar voz à mulher num período histórico em que ela ainda não possuía esse direito, a narrativa mais uma vez se aproxima das características pós-modernas identificadas por Linda Hutcheon (1991, p. 91), pois a voz feminina de O tempo e o vento é uma legítima voz ex-cêntrica, pelo fato de que as mulheres da trilogia "eram consideradas como parte da propriedade acumulada por seus maridos, e negava-se-lhes a cidadania" e por isso criam e defendem "sua própria comunidade, com base em seus próprios valores".

Conforme já abordamos anteriormente, O tempo e o vento Erico Verissimo segue o modelo de representação ficcional do romance histórico tradicional, apresentando a “intersecção entre os acontecimentos históricos e as existências individuais agrupadas em sociedade" (JAMESON, 2007, p. 188), mostrando como a história interfere na vida das pessoas da família Terra-Cambará, num período de 200 anos entremeados de guerras e revoluções violentas, nas quais os membros da família são constantemente afetados. Nesse contexto, os homens da família vão para as guerras, de onde voltam feito heróis ou feridos, enquanto que as mulheres ficam em casa rezando por seus familiares que estão no conflito. Ou seja, conforme a observação feita por Regina Zilberman (2004) a família constituída passa a ser o elemento de agregação de onde saem os soldados para as guerras e as mulheres para a sustentação do lar.

Uma das primeiras guerras a serem abordadas na trilogia é um conflito entre Portugal e Espanha que tem repercussão na fronteira meridional do Brasil. Contra os absurdos dessa guerra vai se levantar a voz de Ana Terra, uma mulher já marcada pela violência, pois além de 
assistir à morte do pai e de um irmão no assalto feito por um grupo de castelhanos à estância paterna, também é estuprada por eles. Assim, a possibilidade de perder também o seu filho nesse conflito faz com que cresça o seu sentimento de revolta com um mundo que ela não conseguia compreender. Dessa forma, Erico Verissimo utiliza para denunciar o horror da guerra a voz feminina de uma personagem diretamente afetada pelo conflito armado, ou seja, alguém que sofre na pele a violência e a desumanidade provocada por ele. Vejamos então a reação dela após procurar o coronel Ricardo Amaral, chefe político do povoado de Santa Fé, para implorar que não levasse o seu filho para o front, e ter seu pedido negado:

Ana Terra sentiu uma revolta crescer-lhe no peito. Teve ganas de dizer que não tinha criado o filho para morrer na guerra nem para ficar aleijado brigando com os castelhanos. Guerra era bom para homens como o Cel. Amaral e outros figurões que ganhavam como recompensa de seus serviços medalhas e terras, ao passo que os pobres soldados às vezes nem o soldo recebiam.

(...)

Dois ou três dias depois Ana Terra disse adeus ao filho. Apertou-o contra o peito, cobriu-lhe o rosto de beijos e a muito custo conteve as lágrimas. Outras mulheres despediam-se chorando de seus homens. Havia um ar de desastre e luto em todas as caras. (VERISSIMO, 1995h, p.142)

Pela voz de Ana Terra, Erico Verissimo denuncia uma injustiça histórica: a conveniência da guerra para os estancieiros que aproveitam o momento de desestabilização política para ampliar seus domínios e enriquecerem cada vez mais à custa das vidas de pobres soldados e colonos que habitavam em suas terras, enquanto que para as famílias desses homens anônimos, esquecidos pela história, a única recompensa que se podia esperar era continuar vivo num cenário de morte, miséria e destruição.

Quando Santa Fé recebe notícias da guerra, favoráveis aos portugueses, contadas por um homem recém-chegado ao povoado, Ana volta a questionar o caráter nobre da guerra, ao ouvir uma exclamação de alegria e orgulho, pelas terras conquistadas, feita pelo forasteiro:

Lá pelo fim daquele inverno um próprio chegou e disse:

- A guerra anda aqui por perto 
Muitas pessoas, velhos e mulheres, aproximaram-se dele e ouviram o homem contar que um tal Santos Pedrozo com uns vinte soldados derrotara a guarda castelhana de San Martinho e apoderara-se das Missões. E, com um largo sorriso na cara marcada por uma cicatriz que lhe ia do canto da boca à ponta da orelha, acrescentou:

- Agora todos esses campos até o Rio Uruguai são nossos!

Ana Terra sacudiu a cabeça lentamente, mas sem compreender. Para que tanto campo? Para que tanta guerra? Os homens se matavam e os campos ficavam desertos. Os meninos cresciam, faziam-se homens e iam para outras guerras. Os estancieiros aumentavam as suas estâncias. As mulheres continuavam esperando. Os soldados morriam ou ficavam aleijados. Voltou a cabeça na direção dos Sete Povos, e seu olhar perdeu-se vago, sobre as coxilhas. (VERISSIMO, 1995h, p.144)

A reflexão feita por Ana Terra lembra o diálogo entre Maria Valéria, tataraneta de Ana Terra, com Flora Cambará, mulher do Dr. Rodrigo Cambará, travado bem mais de 100 depois, respectivamente na Revolução gaúcha de 1923, presente em O arquipélago, terceiro romance da trilogia:

Eu sei, você não quer ouvir todas estas histórias porque tem medo. Prefere se iludir. Mas uma mulher nesta terra tem de estar preparada para o pior. Os homens não tem juízo, vivem nessas folias de guerras. Que é que a gente vai fazer senão ter paciência, esperar, cuidar da casa, dos filhos... Os homens dependem de nós. Como dizia a velha Bibiana, quem decide as guerras não são eles, somos nós. Um dia eles voltam e tudo vai depender do que encontrarem. Não se esqueça. Nós também estamos na guerra. E ninguém passa por uma guerra em branca nuvem. (VERISSIMO, 1995g, p.277)

Essas reflexões sobre a guerra, feitas por duas personagens diferentes, confirmam a perspectiva cíclica e determinista da história, que condiciona as existências individuais às estruturas políticas e sociais, escolhida pelo autor justamente para desmitificá-la, para mostrar que a guerra não é feita apenas de glória e sim de muita violência e horror, e que a beleza da história, onde deveria estar o reconhecimento da verdadeira glória, está justamente na resistência de pessoas simples, que sofreram as suas arbitrariedades, e não nos heróis consagrados pela história oficial que muitas vezes se utilizavam da guerra para ampliar suas propriedades à custa dos mais pobres. 
Desse modo, a voz feminina é um símbolo de resistência da vida diante da morte, que se ergue para denunciar uma ordem injusta ou aclarar os vãos obscuros da história. Nesse sentido é pertinente a observação feita por Flávio Loureiro Chaves sobre a importância do elemento feminino no conjunto da obra de Erico Verissimo:

O complexo tecido da vida rasgado pelas mais diferentes manifestações da violência, sempre se recompõe na capacidade amorosa das personagens femininas. Essa nota existencial obsessivamente repetida de livro para livro, de história para história, constitui a solução - romântica, repetimos, para a trajetória das personagens de Erico Verissimo. É nas mulheres, sempre moralmente mais fortes do que os seus homens, que se estabelece o sustentáculo do mundo que ameaça desabar. Os homens são personagens do presente, como Vasco e o Capitão Rodrigo de $O$ continente, heróis e guerreiros; as mulheres são a força de preservação, cabe a elas assegurar a continuidade de um mundo que se volta sempre para o futuro. (CHAVES, 1972, p.77)

É essa força de preservação que Bibiana Terra vai encarnar depois de ter o marido morto na Guerra dos Farrapos, tomando para si a missão de criar, sozinha, os dois filhos pequenos, a exemplo do que fizera anteriormente sua avó Ana Terra. A jovem viúva não compreende direito o porquê daquela guerra e só tem certeza de que é preciso sobreviver de qualquer jeito porque a vida de seus filhos depende dela. Ao visitar a sepultura do marido junto com os dois filhos, Bolívar e Leonor, ela reflete sobre a guerra e a necessidade de persistir:

Mentalmente conversava com Rodrigo, dizia-lhe coisas. Seus olhos estavam secos. Às vezes parecia que ela toda estava seca por dentro, incapaz de qualquer sentimento. No entanto a vida continuava e a guerra também. A Câmara Municipal de Santa Fé tinha aderido à Revolução. O velho Ricardo Amaral estava morto. Bento havia emigrado para o Paraguai com a mulher e o filho. Diziam que os imperiais tinham de novo tomado Porto Alegre. Bibiana não sabia nem queria saber se aquilo era verdade ou não. Não entendia bem aquela guerra. Uns diziam que os Farrapos queriam separar a Província do resto do Brasil. Outros afirmavam que eles estavam brigando porque amavam a liberdade e porque tinham sido espezinhados pela Corte. Só duma coisa ela tinha certeza: Rodrigo estava morto e rei nenhum, santo nenhum, deus nenhum podia fazê-lo ressuscitar. Outra verdade poderosa era a de que ela tinha dois filhos e havia de criá-los direito, nem que tivesse de suar sangue e comer sopa de pedra. (VERISSIMO, 1995h, p.308-309) 
A resistência de Bibiana, a teimosia em viver e criar os filhos, herdada da avó, é uma das maneiras de Erico Verissimo demonstrar a força da vida diante dum cenário de morte. Mesmo que a guerra semeie a morte por todos os lados, a vida persiste. Nesse sentido, a cena que se passa na capela de Santa Fé, no exato momento do combate entre farrapos e imperialistas, em que uma mulher entra em trabalho de parto, é uma grande metáfora da força da vida na luta desigual contra a morte:

\begin{abstract}
A capela estava cheia de gente, principalmente de mulheres. O vigário deu conselhos aos santa-fezenses, instruindo-os sobre o que deviam fazer na hora do combate, e pediu a Deus que protegesse Santa Fé e seus habitantes. Todos começaram a rezar um padre-nosso em coro. A oração foi entrecortada de soluços. E quando estavam a dizer - "agora e na hora de nossa morte..." ouviu-se ali na capela um grito agudo. Cabeças voltaram-se na direção do grito... Uma mulher estava caída no chão, gemendo. Todos compreenderam imediatamente. Era Maria da Graça, a filha de Chico Pinto. "Ela vai ter criança!" - exclamou alguém. (VERISSIMO, 1995h, p.301)
\end{abstract}

É significativo o fato de o grito da mulher vir bem no momento em que as pessoas abrigadas na capela pronunciavam na oração “... na hora de nossa morte...”, assim como é significativo também o seu nome, Maria da Graça. É o grito da vida dizendo não à morte, reivindicando seu direito de existir num momento extremamente delicado e desfavorável em que a morte estendia sua sombra fúnebre pelo povoado.

A cena do parto em cenário de guerra vai se repetir na representação da Revolução Federalista de 1893 nos sete capítulos intitulados "O sobrado", de O continente. Esses capítulos, estruturados como se fossem um diário de guerra, cobrem o curto espaço de tempo de três dias, da madrugada de 25 a 27 de junho de 1895, período em que a família de Licurgo Cambará, intendente e chefe político republicano de Santa Fé, está cercada no sobrado pelas forças federalistas. Neles, Erico Verissimo vai mostrar toda a desumanidade da guerra através do drama que se desenvolve no sobrado porque, além de toda privação que um conflito 
impõe, Alice, esposa de Licurgo, está prestes a dar a luz e necessita de um médico urgentemente, sob o risco de morrer no parto.

Aqui entra um elemento novo no enredo, pois devido à ascensão social, econômica e política de Licurgo Terra Cambará, este se torna também um agente da história, ou seja, dentro dos seus limites territoriais é alguém que pode interferir nos rumos dela. E assim travase outra batalha dentro do sobrado entre ele e sua cunhada Maria Valéria Terra e seu sogro Florêncio que, ao contrário de Licurgo, não agem e ainda sofrem as vicissitudes dos acontecimentos históricos. Diante da constante negativa de Licurgo em pedir trégua aos federalistas para poder chamar um médico para cuidar da mulher e de um ferido em estado grave, Florêncio argumenta diplomaticamente com o genro, tentando chamá-lo à razão:

- Olhe, Licurgo, vassuncê tem só quarenta anos. Eu tenho quase sessenta e cinco. Já vi outras guerras. Tudo isso passa. A revolução termina, os federalistas e os republicanos ficam alguns meses ou anos um pouco estranhos, mas o tempo tem muita força. Um dia se encontram, fazem as pazes, esquecem tudo. Todos são irmãos. Mas a vida duma mulher ou duma criança é coisa mais importante que qualquer ódio político. (VERISSIMO, 1995h, p.14)

As palavras de Florêncio Terra seriam concretizadas três décadas depois quando republicanos e federalistas estariam juntos na Revolução de 30, ao lado de Getúlio Vargas. Mas, com Maria Valéria o diálogo é tenso, há um verdadeiro combate verbal entre os dois quando ela lhe pede, depois de Alice ter dado à luz a uma criança morta, para pedir trégua para poder chamar um médico para salvar a irmã, que está muito fraca devido às complicações do trabalho de parto, e também um homem gravemente ferido que pode morrer a qualquer momento:

- Mas que quer que eu faça?

- Já lhe disse mil vezes. Bote uma bandeira branca na frente da casa, peça uma trégua, diga que é pra salvar a vida dum cristão. Não. De dois. Chame o Dr. Winter. Ele pode trazer remédios pra Alice e os petrechos pra cortar a perna do Tinoco.

- Já lhe disse que não peço favor a maragato. 
- Prefere então deixar aquele coitado apodrecendo aos poucos na despensa?

- Não prefiro coisa nenhuma. Guerra é guerra.

(...)

- Ouça o que lhe digo. Ainda há tempo de salvar Tinoco.

- Milhares de homens têm morrido nesta revolução por causa de suas idéias.

A vida duma pessoa não é tão importante assim. Há coisas mais sérias.

- O seu orgulho, por exemplo. (VERISSIMO, 1997d, p. 162)

(...)

- É melhor a senhora ir calando a boca. Como chefe político, tenho deveres que uma mulher não pode compreender.

Maria Valéria está pálida e seus lábios tremem um pouco quando ela diz:

- De política não entendo nem quero entender. Só sei que minha irmã está doente e precisa dum doutor e de remédio. Só isso que sei.

(...)

Tenho a mais absoluta certeza que amanhã, o mais tardar, os republicanos chegam e a cidade fica livre desses maragatos.

Maria Valéria fita em Curgo os olhos graúdos, quase exorbitados;

- Podemos então fazer três enterros ao mesmo tempo - diz ela - O da criança, o do Tinoco e o da Alice.

Curgo cresce para a cunhada, como se a quisesse esbofetear.

- Cale essa boca, sua...

Ouve-se um tiro. Outro. E outro. E o tiroteio começa, cerrado. (VERISSIMO, 1995h, p. 163)

Essa tensão entre o mundo masculino e o feminino perpassa toda a trilogia $O$ tempo $e$ $o$ vento. E esse recurso estrutural é uma das estratégias de que Erico Verissimo lança mão para questionar e desmitificar a história oficial, principalmente o caráter glorioso da guerra, pois ao dar voz a um elemento sempre silenciado pela história, a voz feminina, ele está recontando a história sob outro ponto de vista, dos excluídos, daqueles que sempre sofreram, de uma forma ou de outra, as barbáries de atos muitas vezes considerados como heroicos. Por conta disso, são reforçadas as características do novo romance histórico que a narrativa possui pelo fato de

$1-(.$.$) fazer uma releitura crítica da história;$

2 - A releitura proposta por esse romance impugna a legitimação instaurada pelas versões oficiais da história. Nesse sentido a literatura visa suprir as deficiências da historiografia tradicional, conservadora e preconceituosa, dando voz a tudo aquilo que foi negado, silenciado ou perseguido pela história;

3 - A multiplicidade de perspectivas possíveis faz com que não haja uma só verdade do fato histórico. A ficção confronta diferentes versões que podem ser até mesmo contraditórias; (...) (ESTEVES, 1995, p. 29-30) 
Dessa forma, ao desmitificar a nobreza da guerra, denunciando os seus horrores e a sua desumanidade, Erico Verissimo está tomando a sua posição diante da sociedade e assumindo a sua parte na defesa do homem contra todas as violências e injustiças. Por meio de sua escrita literária, ele lança luz sobre a realidade do mundo, iluminando os seus pontos de penumbra para que ele não caia em completa escuridão, e para que seu leitor perceba que por trás de toda a grandeza da guerra difundida pela história oficial há também um lado de dor, miséria e morte.

\subsubsection{A desconstrução do mito da democracia racial gaúcha}

Conforme acertadamente observou Lúcia Helena (2005), observação à qual já nos referimos anteriormente, em $O$ tempo $e$ o vento Erico Verissimo não buscou a síntese harmoniosa dos contrários como fizeram os escritores do século XIX, que procuravam ocultar a violência do processo colonizador e de formação da sociedade brasileira. O que vemos na trilogia é um desmascaramento das relações preconceituosas existentes na sociedade a partir das diferenças entre etnias e classes sociais. Ou seja, fiel a seu projeto literário de "realizar um corte transversal da sociedade", o escritor revela a engrenagem social e seus mecanismos, de modo a mostrar o homem na sua dinâmica social e o indivíduo em sua humanidade, mostrando assim "o paradoxo que é o homem no mundo" (SARTRE, 1994, p. 64).

Dessa forma, utilizando-se de um processo de representação típico do romance histórico, ao qual acrescenta a polifonia de vozes, Erico Verissimo faz, principalmente em $O$ continente, uma reconstituição do modo de vida e do modo de pensar das pessoas que viveram no período histórico abordado, e assim revela toda a hipocrisia social e o preconceito que ela ocultava. 
Nesse sentido, Erico Verissimo sutilmente desconstrói "o mito da democracia racial gaúcha" que pregava a inexistência de qualquer tensão nas relações entre negros e brancos no estado do Rio Grande do Sul, muito antes de Fernando Henrique Cardoso fazê-lo em sua tese Capitalismo e escravidão no Brasil meridional (1997), escrita nos anos 60.

Segundo Maria Angélica Zubaran (1999, p. 18), o mito da democracia racial gaúcha, termo cunhado por Fernando Henrique Cardoso para contestá-lo, surgiu na historiografia riograndense tradicional a partir dos relatos dos viajantes estrangeiros Nicolau Dreys e Saint Hilaire, que "sustentavam uma visão idílica das condições de vida dos escravos nas estâncias gaúchas e defenderam a ideia de uma escravidão amena no Rio Grande do Sul em comparação com outras províncias". Essa visão equivocada foi incorporada pelos historiadores Walter Spalding, Salis Goulart e Dante Laytano até ser derrubada pela tese de Fernando Henrique Cardoso, já mencionada anteriormente. De acordo com Hermógenes Saviani Filho (2008, p. 16), "esse mito foi tão forte que os primeiros autores a escreverem sobre o Rio Grande do Sul tinham a convicção de que na província sul-rio-grandense os escravos eram melhores tratados do que nas demais regiões brasileiras".

Erico Verissimo insere o mito da democracia racial gaúcha em $O$ tempo e o vento através da voz de Florêncio Terra, sogro de Licurgo. Um homem simples, de boa índole, que acredita que os negros são bem tratados no estado gaúcho.

- Não tenho e nem nunca tive escravos. Mas acho que no Rio Grande os negros são felizes. Nas estâncias e nas charqueadas eles trabalham ombro a ombro com os brancos. A não ser um ou outro caso, em geral são bem tratados. Dizem que lá no Norte os senhores de engenho maltratam os escravos. Não sei. Há muita conversa fiada. O que sei é que aqui na Província os negros passam bem. (VERISSIMO, 1995h, p. 595)

No entanto, Erico Verissimo vai sutilmente desconstruir esse mito por meio de outras vozes que põem por terra a crença de Florêncio. Dessa forma, através das falas e dos pensamentos das personagens que foram contemporâneas à escravidão, o narrador nos revela 
por meio desse recurso polifônico o conceito que elas tinham sobre o negro, conceito esse muitas vezes ambíguo, dada a tensão entre o que queriam pensar e o que realmente pensavam. Uma das passagens mais reveladoras nesse sentido acontece no enforcamento do negro Severino, que ocorre simultaneamente à cerimônia de noivado de Bolivar Cambará e Luzia Silva e a poucos metros do sobrado onde ela se realiza. Ao comentarem o caso, Luzia afirma de forma taxativa: "Negro não é gente" (VERISSIMO, 1995h, p. 378); Florêncio Terra pensa que a moça falou um disparate; Bolivar parafraseia mentalmente as palavras da noiva: "Severino não é gente. Vão enforcar um bicho" (Ibid., p.379), enquanto que o Dr. Carl Winter apressa-se em dizer que Luzia falou uma inverdade científica, ao que ela responde de imediato: "Não sei se o que eu disse é científico ou não. Mas é o que sinto. Para mim o negro está mais perto do macaco que dos seres humanos" (Ibid.), seguindo-se imediatamente a réplica do médico:

- Mein liebes Fräulein! repetiu o Dr. Winter. Como pode a minha graciosa amiga conciliar seu cristianismo com essas ideias? - perguntou Winter, balançando o corpo na ponta dos pés. - Onde está sua caridade? Que um herege como eu pense assim, ainda se admite. Mas que uma jovem cristã diga essas barbaridades, mein Gott!, isso eu não compreendo! (Ibid.)

Através da contradição existente em Luzia, o cristianismo e a desumanidade convivendo no mesmo ser, Winter chama a atenção para o grande paradoxo da sociedade brasileira da época: ser cristã e ao mesmo tempo ser escravocrata. E mesmo aqueles que aceitavam a humanidade do negro, como o juiz Nepomuceno, "às vezes não deixava de sentir nas pessoas de cor qualquer coisa de bestial que as aparentava aos animais inferiores" (Ibid.,p. 380). Enquanto se discutia no sobrado a condição humana ou não do negro, lá fora, na praça de Santa Fé, uma multidão se reunia para assistir ao enforcamento de Severino, como um espetáculo público. Vale lembrar que não havia provas contundentes sobre a culpa de Severino pela morte de dois homens e a sua condenação se baseou mais no fato de ele ser negro do que pelas precárias provas apresentadas. 
No entanto, a nosso ver, a cena mais representativa da discriminação do negro dentro da narrativa acontece algumas décadas depois do enforcamento de Severino, já em pleno período abolicionista, quando Licurgo Cambará, líder do Partido Republicano em Santa Fé, alforria 31 escravos de sua propriedade. Erico Verissimo destrói o gesto nobre do estancieiro ao desvendar seus pensamentos ambíguos em relação ao negro e à causa abolicionista, revelando que por trás da louvável atitude dele se escondia uma vaidade pessoal e uma finalidade política. Vejamos então o pensamento de Licurgo Cambará durante uma conversa com o capataz Fandango:

Licurgo tornou a encher a cuia d'água e passou-a a Fandango. E enquanto o velho ficou entretido a chupar na bomba, ele falou com entusiasmo nos festejos do dia. Tinha a impressão - disse - de que o baile de gala do Paço Municipal, com suas formalidades e seus medalhões, ia ficar apagado diante da festa do Sobrado, onde reinaria a verdadeira democracia: negros e brancos, ricos e pobres, todos misturados e irmanados no ideal abolicionista e republicano. Mas no momento mesmo em que dizia essas coisas, Curgo percebeu que não estava sendo sincero, que não estava dizendo o que sentia. Era lhe inconcebível a ideia de que aqueles negros sujos pudessem vir dançar nas salas de sua casa, em íntimo contato com sua família. (VERISSIMO, 1995h, p. 570)

Dessa forma, a atitude nobre de Licurgo, provocada pelo seu ardor político e pela sua vaidade pessoal, contrasta com o seu próprio pensamento que lhe destrói a grandeza do gesto. Mas o contraste não se dá apenas entre a atitude e o pensamento de Licurgo, ele também ocorre na configuração do espaço narrativo da cerimônia de alforria: enquanto os brancos, limpos e bem vestidos, festejam o grande evento na sala principal do sobrado, os negros, sujos e mal vestidos, fazem a sua festa do lado de fora, no quintal da casa. Eles só têm acesso ao interior do sobrado no momento de receber os títulos de manumissão e depois são enxotados para fora, pois o benfeitor já começa a se irritar com o cheiro e visão deles dentro de sua casa. Nesse sentido, a cena do evento é de segregação e não de integração do negro à sociedade, conforme podemos observar no trecho abaixo: 
A chamada continuava. Negros entravam e saiam. Havia entre eles homens e mulheres, moços e velhos. Licurgo começava a irritar-se. A cerimônia não só se estava prolongando demais, como também não oferecia metade da emoção que ele esperava. (...)

E o desfile continuou. Licurgo mal podia conter sua impaciência. Não conseguia convencer-se a si mesmo de que aquela era uma grande hora uma hora histórica. Não achava nada agradável ver aqueles negros molambentos e sujos, de olhos remelentos e carapinha encardida a exibir toda a sua fealdade e sua miséria naquela casa iluminada. E como eram estúpidos em sua maioria! Levavam a vida inteira para atravessar a sala e depois ficavam com o papel na mão, atarantados, sem saber que fazer nem para onde ir. Era preciso que ele gritasse: "Agora vá embora. Não! Por ali. Volte pro quintal".

O pior era que o sobrado já começava a cheirar senzala. (VERISSIMO, 1995h, p. 630)

O narrador, ao expor os pensamentos de Licurgo, nos revela toda a hipocrisia do ato do líder abolicionista, mostrando aquilo que está subjacente ao seu discurso e ao seu gesto. Por mais que ele se esforce para aparentar naturalidade e tratar os negros como seres livres e iguais, no fundo ele os considera como seres desprezíveis, e assim deixa claro para o leitor que o aparente gesto nobre só deu por conta de uma necessidade política e também por uma vaidade pessoal, tanto é que o que lhe trouxe alguma emoção não foi o seu gesto libertador e sim os aplausos, os abraços e o reconhecimento do gesto por parte dos seus correligionários. E quando a entrega dos títulos termina, a matriarca Bibiana Terra Cambará, que considerava "o maior disparate do mundo dar liberdade àquela gente" (VERISSIMO, 1995h, p. 573) e só aceitou o ato por causa do neto, sem meias palavras pede aos criados: "- Agora abram as janelas pra sair o bodum" (VERISSIMO, 1995h, p. 631), verbalizando aquilo que Licurgo e muitos dos presentes sentiam e pensavam.

No entanto, o preconceito ao negro não acontece somente entre pessoas da classe alta. Ele está igualmente presente entre pessoas pobres e simples, como o capataz Fandango, que a exemplo de Bibiana também condena o ato de Licurgo de libertar os escravos. Para ele, os negros são vadios e cachaceiros e nasceram para serem mandados, conforme podemos observar na sua conversa com Licurgo. 
- Eu só quero ver o que é que essa negrada vai fazer depois que receber papel de alforria.

(...)

- Vassuncê vai ver - prosseguiu o capataz. - Recebem dinheiro e gastam tudo em cachaça. Vão passar o dia na vadiagem, dormindo ou se divertindo. Nenhum desses negros alforriados vai querer trabalhar. No fim acabam morrendo de fome. (VERISSIMO, 1995h, p. 568)

Desse modo, embora haja quem considere que a presença dos negros em $O$ tempo e o vento seja inexpressiva, como, por exemplo, o historiador Mario Maestri (1994, p. 7), para quem Erico Verissimo colaborou na operação do embranquecimento do passado gaúcho, ao referir-se aos negros e aos escravos em $O$ continente "como se fizessem parte de uma paisagem seminatural, ao lado dos bens móveis e imóveis de uma fazenda" ${ }^{12}$, pensamos que a maneira escolhida por Erico Verissimo para abordar o problema da escravatura na trilogia foi uma estratégia narrativa para evidenciar que as relações entre brancos e negros não eram assim tão amistosas como fazia crer a historiografia oficial, e que havia sim tensões nas relações entre eles, o que vale dizer que o escritor procurou desconstruir o mito da democracia racial gaúcha, conforme previa o projeto de escrita de $O$ tempo e o vento, de desmitificar a história do Rio Grande do Sul e mostrar como eram por dentro os homens e as mulheres que viveram no passado.

Ao fazer isso, Erico Verissimo soube como auscultar o diálogo daquela época, como diria Bakhtin (1997), e representá-lo literariamente, mostrando a visão de mundo das personagens que teriam vivido nela, de modo "a captar nela não só as vozes isoladas mas antes de tudo as relações dialógicas entre as vozes, a interação dialógica entre elas" (BAKHTIN, 1997, p. 89). A utilização desse recurso também reforça a presença de algumas características do novo romance histórico em $O$ tempo e o vento, já citadas no item anterior sobre a desmitificação da guerra.

\footnotetext{
${ }^{12}$ Essa afirmação de Mário Maestri foi contestada pela professora Ligia Chiappini no ensaio "O continente, a estância e os escravos", publicado em PESAVENTO, Sandra et. al (org.). Erico Verissimo e o romance da história. São Paulo: Nova Alexandria, 2001.
} 


\subsubsection{A metaficção}

Além de todas as desmitificações que a trilogia faz, ela também se desmitifica enquanto ficção, deixando visível a sua "natureza de artefato literário" (WHITE, 1994), pelo fato de ela ser também uma narrativa metaficcional. A metaficção é inserida em $O$ tempo e $o$ vento através da entrada em cena da personagem-escritor Floriano Cambará, filho mais velho de Rodrigo, que surge no capítulo final de $O$ retrato, "Uma vela pro negrinho", e passa ter uma importância fundamental em $O$ arquipélago, romance que fecha a trilogia.

Floriano Cambará, alter-ego assumido do escritor, planeja escrever um romance que vai se delineando no decorrer da narrativa com as mesmas características de $O$ tempo e o vento: o enfoque na saga de uma família tendo a história do Rio Grande do Sul como pano de fundo, durante um período de 200 anos.

A ideia inicial desse projeto surge durante uma conversa com Roque Bandeira, seu amigo e confidente, uma personagem que funciona na estrutura do romance como uma espécie de contraponto intelectual de Floriano, ou talvez a sua autoconsciência. Nesse diálogo, Floriano reconhece, meio constrangido, o seu desenraizamento e Bandeira aponta-lhe um possível caminho de reconciliação consigo mesmo e com a terra natal, que seria escrever uma obra literária sobre a sua terra e sua gente.

Essa preocupação será tema de várias outras conversas com Roque Bandeira e, principalmente, será um dos principais assuntos registrados no "Caderno de pauta simples". capítulos intermediários de $O$ arquipélago. Desse modo, no segundo episódio do "Caderno de pauta simples", Floriano escreve:

Penso num novo romance. Solução - quién sabe! - para muitos dos problemas deste desenraizado. Tentativa de compreensão das ilhas do arquipélago a que pertenço ou, antes, devia pertencer. Abertura de meus portos espirituais ao convívio das outras ilhas.

$(\ldots)$ 
Escrever sobre a minha terra e minha gente - haverá melhor maneira de conhecê-las?

Conhecê-las para amá-las. Mas amá-las mesmo que não consiga compreendê-las. (VERISSIMO, 1995g, p.237)

Concebida a ideia, o próximo passo seria então pensar em “como fazer". Aos poucos o romance vai sendo delineado pelo escritor, e assim vamos acompanhando toda a sua mimese do processo: as suas dúvidas, os seus impasses, o seu "questionamento de como levar a termo o projeto de escrita que se propôs a fazer" (FARIA, 2008, p.3). No quinto episódio do "Caderno de pauta simples", já vislumbramos um esboço do que vai ser o romance de Floriano, e aquilo que estava sendo enunciado de forma implícita, dessa vez é afirmado explicitamente, e então tomamos conhecimento que o romance que está sendo gestado por Floriano é, nada mais nada menos, do que o próprio romance que estamos lendo:

Já vejo claro o que vai ser o novo romance. A saga duma família gaúcha e de sua cidade através de muitos anos, começando o mais remotamente possível no tempo. Talvez no Presídio do Rio Grande, no ano de sua fundação, com um soldado ou um oficial do Regimento de Dragões. Não! Tenho uma ideia melhor. Vejo o quadro.

1745. No topo duma coxilha, uma índia grávida, perdida no imenso deserto verde do Continente. O filho que traz no ventre é dum aventureiro paulista que preou, emprenhou e abandonou.

A criança nasce na redução jesuítica de São Miguel, onde a bugra busca refúgio. A mãe morre durante o parto, esvaída em sangue. A fonte... Porque esse bastardo, um menino, virá a ser um dos troncos da família que vai ocupar o primeiro plano do romance, e que bem poderá ser (ou parecer-se com) o clã dos Terra-Cambará.

Quero traçar um ciclo que comece nesse mestiço e venha a encerrar-se duzentos anos mais tarde. (VERISSIMO, 1995g, p.747)

Para realizar tal empreitada, de escrever a saga de uma família gaúcha num período de 200 anos, tendo como matéria literária a história de sua própria família, Floriano vai precisar da colaboração da tia Maria Valéria, a Dinda, a guardiã da memória da família TerraCambará. Somente ela tem a chave para abrir a porta que dá acesso aos acontecimentos já esquecidos e perdidos no tempo, e por isso ele a vê como um "farol", que pode iluminar-lhe caminhos que ficaram para trás. 
Mesmo vivendo a euforia do planejamento do livro, Floriano tem plena consciência dos vários problemas que enfrentará para dar vida a uma obra dessa magnitude. A dificuldade da seleção das personagens e dos episódios mais significativos, a forma de lidar com o tempo num período tão vasto, a escassez de informações do passado mais distante e a abundância delas no passado recente são alguns dos problemas a serem enfrentados na composição do romance. À parte disso, o romancista também tem consciência de que precisa escrevê-lo.

Essa ansiedade mesclada com angústia se prolonga até às páginas finais do romance, quando, alguns dias após a morte do pai, ao chegar ao sobrado depois da meia-noite, da noite de reveillon de 1945, Floriano consegue finalmente escrever o primeiro parágrafo romance:

Floriano entrou em casa depois da meia-noite, quando já haviam cessado nas ruas os ruídos das comemorações, e a noite se preparava para ser madrugada. (...)

$\mathrm{Na}$ véspera havia feito várias tentativas frustradas para iniciar o romance. Para ele o mais difícil fora sempre começar, escrever o primeiro parágrafo. O papel já estava na máquina, mas ainda completamente em branco.

Tirou o casaco, aproximou-se da janela, sentou-se no peitoril e ali se deixou ficar, como a pedir o conselho da noite. Viu o cata-vento da torre da igreja, nitidamente recortado contra o céu, e pensou nas muitas histórias que ouvira, desde menino, sobre a Revolução de 93. Uma havia segundo a qual, durante o cerco do Sobrado pelos federalistas, na noite de São João de 1895, o Liroca tinha ficado atocaiado na torre da igreja, pronto a atirar no primeiro republicano que saísse do casarão para buscar água no poço. Por que não começar o romance com essa cena e nessa noite?

Sentou-se à máquina, ficou por alguns segundos a olhar para o papel, como que hipnotizado, e depois escreveu dum jato:

Era uma noite fria de lua cheia. As estrelas cintilavam sobre a cidade de Santa de Fé, que de tão quieta e deserta parecia um cemitério abandonado. (VERISSIMO, 1995g, 1013-1014)

Desse modo, o romance de Erico Verissimo termina com o início do romance de Floriano Cambará, pois as palavras datilografadas pela personagem são as mesmas com que o autor começa $O$ continente, remetendo o leitor ao primeiro romance da trilogia, concretizando-se assim uma "duplicação repetida in infinitum da mise em abyme" (HUTCHEON, 1984). Nesse sentido, é significativo o fato de Floriano iniciar a escrita do seu romance na noite de reveillon, pois, como sabemos, essa noite comporta o fim de um ano e 
começo de outro, sendo que o ano que se inicia irá repetir a mesma cronologia do ano que se findou, os mesmos dias e os mesmos meses até se findar e dar início a outro ano, tal qual a trilogia $O$ tempo e o vento, cujo fim remete a seu início sucessivamente, na forma de um autoespelhamento infinito.

No entanto, conforme observa Regina Zilberman (2004), o uso desse artifício muda completamente a perspectiva de leitura da obra, pelo fato de que o narrador deixa de ser anônimo e se revela uma personagem integrante da família cuja história ele está narrando, tornando os seus julgamentos subjetivos e pessoais. Dessa forma, através da metaficção, Erico Verissimo desmitifica também a própria trilogia, que adquire outra característica do novo romance histórico, que é "a metaficção ou comentários do narrador sobre o processo de criação", conforme a definição de Seymour Menton (1993, p. 43). 


\section{4 - O PROJETO LITERÁRIO DE PEPETELA}

O escritor angolano Artur Carlos Maurício Pestana dos Santos, mais conhecido como Pepetela, começou sua carreira literária no final da década de 50, publicando alguns contos na Revista Mensagem e na antologia Novos contos d'África, período em que estava radicado em Lisboa como estudante, primeiro de Engenharia e depois de História, e participava ativamente das atividades políticas e culturais da Casa dos Estudantes do Império (CEI), onde, segundo ele, começou a aliar o trabalho político à preocupação social, ligação que marcaria todo o seu projeto literário.

Desse modo, nos seus primeiros textos publicados já é visível essa preocupação social. Os contos "As cinco vidas de Teresa" e "A revelação", por exemplo, abordam os abusos sexuais cometidos por homens brancos de classe média sobre mulheres negras pobres, prática comum na sociedade angolana colonial, dividida entre o mundo do branco e o mundo do preto.

Depois do 04 de fevereiro de 1961, data em que o Movimento Popular de Libertação de Angola (MPLA) deflagra a Guerra de Libertação Nacional contra o colonialismo português, Pepetela vai para Paris e de lá segue para Argélia, onde se forma em Sociologia pela Universidade de Argel, ficando nessa cidade até 1969, quando segue para Cabinda para participar diretamente da luta armada. É nesse período de seis anos passados em terras argelinas, trabalhando no Centro de Estudos Angolanos, órgão ligado ao MPLA, que ele escreve os seus primeiros romances.

Em entrevista concedida a Michel Laban (1991), Pepetela afirma ter escrito durante esse período vários romances que acabaram se perdendo, devido, acreditamos nós, à situação de diáspora e guerrilha em que o escritor viveu até a independência angolana. Desses 
romances, sobreviveu apenas Muana Puó $(1995)^{13}$, livro que dá início ao projeto literário do escritor, cujos principais objetivos são a tematização da construção da nação angolana e o questionamento do poder político vigente em Angola, seja ele colonial ou pós-independência, utilizando sempre para esse fim a matéria de extração histórica angolana.

Nesse sentido, segundo a declaração feita pelo escritor a Michel Laban (Ibid., p. 771), "as preocupações de fundo, em Muana Púo, são as mesmas de todo o resto que foi escrito depois. Há um tema que é comum, que é o tema da formação da nação angolana. Isso faz o denominador comum". No entanto, segundo pretendemos mostrar mais adiante, o tema da construção da nacionalidade sofre algumas transformações conforme vão se alterando os contextos de escrita. Em tempo, lembramos que essa entrevista foi concedida quando o escritor tinha acabado de lançar o romance Lueji, o nascimento dum império, e depois dessa obra foram publicados, até o momento atual, mais 15 livros, entre os quais um livro de caráter sociológico sobre a cidade de Luanda (Luandando, 2000), um livro de contos (Contos de morte, 2008) e um livro de crônicas (Crônicas com fundo de guerra, 2011). Os demais podem ser considerados romances.

Tendo a formação da nação como o tema principal do seu projeto literário, Pepetela insere-se numa corrente diacrônica de desenvolvimento da literatura angolana que, conforme observa a professora Rita Chaves (2003, p. 374), "Do século XIX aos nossos dias, construir-se enquanto escritor e construir a nação têm sido faces de um mesmo projeto". Ou seja, o processo de construção da literatura angolana é simultâneo ao processo de construção da nação. Aqui é importante lembrar que o processo de independência de Angola surgiu através de um movimento cultural (Movimento dos Novos Intelectuais de Angola) que se transformou num movimento político (MPLA) e que os principais representantes da literatura angolana dos anos 50 aos 80 estavam ligados, direta ou indiretamente, à luta pela

\footnotetext{
${ }^{13}$ As datas colocadas entre parênteses após os títulos referem-se às datas de publicação das edições que estamos utilizando no corpus do trabalho.
} 
independência do país. Nesse sentido, a tarefa para os escritores angolanos era duplamente árdua, segundo afirma Rita Chaves, ao comparar o processo de formação da literatura angolana ao processo de formação da literatura brasileira:

Se entre nós a literatura pretendeu compensar o atraso tecnológico e a precariedade de nossas instituições, para os angolanos a tarefa se apresentava ainda mais heroica: tratava-se (trata-se) de fazer uma nação onde existia um punhado de povos, enredados no jogo das diferenças de suas tradições culturais. O desafio se montava: era preciso fazer Angola, o que significava (significa) investir também na construção de um discurso autônomo capaz de unificar as vozes dispersas pelos quatro cantos do território e calar a voz uniforme do colonialismo. Ao fim e ao cabo, o jogo era um só: bloquear o ato colonial para construir a nação. Noutras palavras, tratava-se de vencer o colonizador para, afinal, legitimar o que era uma invenção sua: Angola. (CHAVES, 1999, p. 31-32)

Ao olharmos a produção literária de Pepetela, percebemos que ele foi um dos principais atores desse duplo processo, pois, concordando com Rita Chaves (2005, p.86), a construção da nacionalidade é "um tema constante que, sob vários ângulos e perspectivas, constitui um elemento matriz em seu repertório". E aqui lembramos, a título de confirmar as declarações anteriores, um trecho de uma entrevista concedida pelo escritor à Maura Eustáquia de Oliveira, em 2002, cerca de um ano antes da morte de Jonas Savimbi e da assinatura do acordo que pôs fim à guerra civil angolana:

Criar, através da literatura, insere-se no mito unificador de Angola, no ideal de reunir etnias e ideologias em torno da construção/reconstrução do país, de tal modo que se forme e se configure, de modo indelével, a identidade nacional dessa terra tão rica e formosa que, hoje, pena sob o peso de uma das mais dolorosas guerras civis da história moderna. (PEPETELA, 2003, p. 363)

$\mathrm{Na}$ condição de um dos principais integrantes desse projeto coletivo de criar uma literatura e uma nação angolanas, Pepetela vai se inserir em duas vertentes que se complementam no processo de desenvolvimento da literatura angolana: a do Movimento dos Novos Intelectuais de Angola e a da formação do romance angolano, seguindo "a trilha aberta por António de Assis Júnior" (CHAVES, 1999). 
Em relação ao Movimento dos Novos Intelectuais de Angola, Pepetela estava em consonância com os pressupostos do movimento que iniciou, a partir de 1948, com o brado "Vamos descobrir Angola", o processo de ruptura no plano cultural com os padrões estéticos europeus. Vale lembrar as palavras do poeta Viriato da Cruz sobre o movimento que mudou o fazer literário angolano, conforme transcrição feita pelo poeta angolano Costa Andrade:

O movimento deveria retomar, mas sobretudo com outros métodos, o espírito combativo dos escritores dos fins do século XIX e dos princípios do actual. Esse movimento combatia o respeito exagerado pelos valores culturais do Ocidente (muitos dos quais caducos); incitava os jovens a redescobrir Angola em todos os seus aspectos através de um trabalho colectivo organizado; exortava a produzir-se para o povo, solicitava-se o estudo das modernas correntes culturais estrangeiras, mas com o fim de repensar e nacionalizar as suas criações positivas e válidas, exigia a expressão dos interesses populares e da autêntica natureza africana, mas sem que se fizesse nenhuma concessão à sede de exotismo colonialista. Tudo deveria basear-se no censo estético, na inteligência e na vontade africanas. (ANDRADE, 1975, p. 6)

Desse modo, o projeto literário de Pepetela já estava, desde o início, alinhado com os objetivos da literatura produzida pelos poetas da geração de 50 e com a prosa produzida pelos romancistas António Assis Júnior, Castro Soromenho, Óscar Ribas e José Luandino Vieira, escritores que, segundo Rita Chaves:

Valendo-se do gênero, empreenderiam projetos de investigação que ajudam
a mapear a fisionomia multifacetada do cenário cultural angolano.
Ancorados no difícil cais de um porto tão convulsionado, esses escritores
viram-se diante de muitos dilemas e compuseram um repertório variado, a
partir da opção por diferentes estratégias artísticas. Unifica-os, porém a
consciência patente de, em maior ou menor escala, precisarem fazer de seus
textos um lugar de resistência às pressões que a condição colonial os
condenava. (CHAVES, 1999, p. 21 )

A literatura produzida por esses escritores, tanto os poetas a partir da geração de 50 quanto os romancistas de Assis Júnior em diante, buscavam construir seus textos imbuídos, em maior ou menor grau, de um sentimento de "angolanidade", um sentimento abstrato que talvez seja o cimento a unir (o mito unificador referido por Pepetela anteriormente) os 
angolanos numa "comunidade imaginada", tal qual foi teorizada por Benedict Anderson (2008). Sobre a definição desse sentimento de angolanidade que permeia os textos literários angolanos e os fazem distinguir-se dos textos da literatura colonial, Pepetela faz a seguinte observação:

(... ) No fundo, todos nós procuramos isso (a angolanidade) $\mathrm{O}$ que é isso? Um conceito abstracto. Tenho a impressão que ninguém sabe muito bem o que é. No fundo, não conseguimos até hoje teorizar, definir o que é isso de angolanidade. Isto, embora esteja patente na obra dos escritores angolanos, claro. Creio que é um conceito que se vai procurar ainda durante muito tempo. (VENÂNCIO; AMMANN, 1990, p. 6-7)

No entanto, ao escrever a nação através de seus romances impregnados de angolanidade, Pepetela também acrescenta a eles um forte questionamento às estruturas sócio-políticas, tanto do período colonial quanto do período pós-independência, realizando uma reflexão constante sobre o processo de formação da sociedade que ele problematiza. Nesse sentido, a professora Tania Macêdo acertadamente observa:

As marcas da história na trilhas da ficção de Pepetela, bem como a presença de um questionamento corajoso a aspectos da conjuntura sócio-política de seu país, podem ser acompanhadas ao longo de toda a produção literária do autor. Veja-se, por exemplo, que o primeiro texto de maior fôlego publicado por Pepetela, As aventuras de Ngunga (...), em linguagem simples, realiza uma crítica quer a certos aspectos da vida tradicional angolana (como o "alembamento"), quer a alguns dirigentes do Movimento, como o velho Kafuxi, que nega comida aos guerrilheiros. (MACÊDO, 2002, p. 319)

Esse questionamento sócio-político corajoso realizado pelo escritor está em consonância com o objetivo de sua escrita que, segundo ele próprio afirma a Michel Laban (1991) é uma escrita que se pretende reflexiva sobre determinados aspectos da realidade, ou seja, é uma forma que o escritor tem de compreender melhor o mundo à sua volta a partir da sua ficcionalização. Ao comentar o processo de escrita de Mayombe, Pepetela observa que na época da escrita do livro dava aulas de formação política aos guerrilheiros e por isso tinha uma atividade intensa durante o dia, trabalhando arduamente para resolver as contradições 
que emergiam no seio do grupo, e à noite tinha a necessidade escrever para compreender melhor essas contradições.

Ora, a forma de eu reflectir é escrever; era para mim. Claro, era uma experiência que eu tinha, de actividade prática e, à noite, digamos que eu teorizava essa experiência para, no dia seguinte ou daí a um mês, ter essa actividade um pouco mais consciente. Esse era o objectivo - um objectivo que se mantém sempre quando eu escrevo: é para eu compreender melhor. Só compreendo uma coisa quando escrevo sobre ela. Antes de escrever, posso ter as minhas intuições, mas é ao escrever que eu vou mais ao fundo. Isso aparece em todos os livros, fatalmente. Se quiser, é um didactismo, mas mesmo em relação a mim próprio: digamos, para eu compreender e, depois, já com uma preocupação com que outras pessoas compreendam e se envolvam nessas contradições.

(...)

Eu gosto é, exactamente, de fazer ficção e, sobre essa ficção, refletir sobre certos problemas que se põe - fundamentalmente esse da nação... (LABAN, 1991, p. 774-775)

Dessa forma, a concepção de escrita para o autor não é gratuita, ela é atravessada por uma necessidade de reflexão que parte, primeiramente do próprio escritor, para, num segundo momento, tentar atingir o leitor, para que ele também participe das contradições e dos conflitos de ideias sobre problemas que atingem a sociedade, pois, conforme Pepetela afirma numa outra entrevista, o seu desafio é "desafiar os angolanos a serem capazes de pensar" (SILVA, 1992). Pepetela constitui-se então como um escritor engajado que, na esteira de Jean-Paul Sartre (2006, p. 49), procura "desvendar o mundo" para propô-lo como uma tarefa à generosidade do leitor para que ele não possa ignorá-lo e considerar-se inocente diante dele, utilizando-se assim a literatura como instrumento contra a alienação.

Nesse sentido, a escrita que ele faz da construção da nacionalidade angolana é permeada por um questionamento constante acerca das estruturas de poder dessa sociedade que se está a construir, num contínuo entrelaçamento entre ficção, história e política. Dessa forma, o projeto literário de Pepetela possui um dupla face: primeiramente ele tematiza a formação da nação angolana, reescrevendo a história do país através da ficção, dando voz a tudo que ficou silenciado nos desvãos da história colonial, mas ao mesmo tempo questiona 
todo esse processo, inserindo no texto literário uma crítica contundente tanto às estruturas de poder colonial quanto às novas estruturas de poder que se estão a construir.

Sob esse aspecto, na sua condição de escritor engajado, Pepetela toma posição em suas obras literárias "contra as injustiças, de onde quer que venham" (SARTRE, 2006, p. 209), com o compromisso intelectual de "promover a liberdade humana e o conhecimento" (SAID, 2005, p.31), construindo uma literatura fiel à sua visão de mundo e ao seu compromisso social e humano, livre de quaisquer compromissos com governos ou partidos políticos. Para tanto, para viabilizar o projeto ético que a sua literatura comporta, sem perder de vista a especificidade literária, o escritor angolano vai se valer da utilização de diversas estratégias narrativas. Dentre as mais frequentes em suas obras, podemos citar a polifonia, a alegoria, o contraponto, a metaficção e estruturação do tempo narrativo. Dessa forma, a radicalidade ética de Pepetela na configuração de seus romances vai ser acompanhada também de uma radicalidade estética.

\subsection{Os primeiros romances}

Devido a situação de diáspora e de atividade na guerrilha em que Pepetela escreveu seus primeiros textos literários, a primeira obra escrita, Muana Puó, em 1969, não foi a primeira a ser publicada. Esse posto cabe a As aventuras de Ngunga, escrita em 1972 e publicada no ano seguinte. No entanto, na abordagem que faremos dos primeiros livros do autor, levaremos em conta não a data de publicação e sim a ordem que foram escritos, para podermos refletir melhor sobre o desenvolvimento e a evolução do seu projeto literário.

Por essa perspectiva, Muana Puó, escrito em Argel em 1969 e publicado somente em 1978, pela União dos Escritores Angolanos (UEA), ocupa a condição de primeiro romance do 
escritor. A obra, cujo título é o nome de uma máscara tchokuê com a qual se dançava no ritual da circuncisão, é estruturada em duas partes, "O passado" e "O futuro" (cada uma com 35 capítulos curtos), e mais um epílogo. Ela narra a luta entre morcegos oprimidos e corvos opressores, a história de amor e desencontro do casal Ele e Ela e a sociedade utópica do futuro, que formam os três planos da narrativa, conforme observam Fernando Martinho (2001) e Helena Riaúzova (1986).

Nesse romance, o autor lança mão de uma escrita alegórica no sentido concebido por Walter Benjamin que, conforme a definição de Flávio Kothe (1976, p. 29) é "a escrita que significa o seu outro, a escrita que é o não-ser do que representa" pelo fato da alegoria significar "dizer o outro", de forma que "nela cada elemento quer dizer outra coisa que não o seu sentido original" (KOTHE, 1986, p. 52). Assim, há um "significado primeiro, aparente, e aquele significado outro, mais verdadeiro, que lhe é subjacente" (Ibid., p. 18).

Nesse sentido, a luta entre corvos e morcegos, o significado aparente, alegoriza a guerra de libertação nacional angolana, o significado verdadeiro, enquanto que a sociedade utópica do futuro, onde "os morcegos tornar-se-ão homens e comerão o mel que criam" (PEPETELA, 1995, p.166), depois de vencerem os corvos, é a sociedade que se deseja para a Angola independente. Mas a alegoria não se resume a apenas a esse fato mais visível, segundo Alberto Pinto de Oliveira (2006), a máscara tchokuê, ou kioka, conforme ele denomina, é também uma alegoria da terra angolana:

(...) Aquela máscara que os kiokos viam como representando a mulher enquanto desejo e companheira do homem, mas também enquanto terra da comunidade, capaz de dar frutos e perpetuar a existência, assume no romance de Pepetela um papel de alegoria da terra angolana, cujas fronteiras definidas pelo colonizador vão ser, depois da libertação da tutela colonial, as de um Estado-nação cuja identidade unirá todos os seus filhos. (OLIVEIRA, 2006, p. 67)

Dessa forma, nesse primeiro romance, apesar da penumbra que a alegoria joga sobre a obra, é possível vislumbrar os dois elementos fundamentais do projeto literário do escritor: o 
sonho utópico da construção da nação angolana aliado a um forte questionamento das estruturas de poder que exploram o homem angolano. Quanto a alegoria, Pepetela voltaria a utilizá-la em obras posteriores como em A revolta da casa dos ídolos (1980), Yaka, Lueji, o nascimento dum império, Parábola do cágado velho (2005) e A gloriosa família, conforme veremos mais adiante.

Dois anos depois, em 1971, enquanto participava diretamente da guerrilha, Pepetela escreveu Mayombe (1982), outro romance que a exemplo do anterior não era para era ser publicado, e só o foi porque circunstâncias futuras possibilitaram a sua publicação em 1980. Nessa obra, em que estão mais nítidos os objetivos do projeto literário do escritor, em função do realismo que dá o tom da narrativa, Pepetela aborda os conflitos vividos por um grupo de guerrilheiros do Movimento Popular de Libertação de Angola (MPLA), numa base militar situada na floresta do Mayombe, na época da guerra de libertação nacional. No entanto, a opção pelo realismo e o abandono da alegoria de Muana Puó não significa dizer o romance tenha um trabalho estético menos apurado que o anterior. Pelo contrário, a preocupação estética acompanha a par e passo a preocupação ética do escritor de se discutir certas contradições que habitavam o seio do movimento revolucionário angolano, como o tribalismo e o racismo, que punham em risco o projeto de construção nacional.

Nesse sentido, para abordar essas contradições e intrigas, Pepetela vai se valer do recurso narrativo da polifonia, que segundo o teórico russo Mikhail Bakhtin (1997, p. 4) consiste na existência de uma "multiplicidade de vozes e consciências independentes e imiscíveis" em relação umas às outras. Dessa forma, a essência da polifonia vai consistir na independência que essas vozes guardam entre si, ao mesmo tempo em que combinam-se "numa unidade de ordem superior à da homofonia" (Ibid., p. 21), harmonizando-se no todo da narrativa. 
Desse modo, para expor os dramas de cada membro do grupo e as intrigas existentes entre eles, o narrador, em terceira pessoa, democraticamente dá voz a todos os guerrilheiros, transformando a narrativa em um vozerio onde todos têm direito à palavra, como se fosse uma discussão aberta, na qual são discutidos os problemas, valores e contradições dos membros do grupo. Ao utilizar tal procedimento, Pepetela revela tanto os conflitos pessoais quanto os coletivos, mostrando os guerrilheiros na sua humanidade, como homens que são corajosos mas que também sentem medo, que amam, odeiam, são capazes de gestos nobres e vis, dependendo das circunstâncias em que estejam. Dessa forma, o escritor mostra uma visão não idealizada do guerrilheiro: eles são heróis, mas não imaculados, e assim, ao mesmo tempo em que constrói a unidade do grupo como uma metáfora da unidade nacional e procura forjar uma identidade nacional a partir da diferença, ele também critica e desmascara certos comportamentos individuais inadequados que podem por em risco o projeto coletivo.

Embora o romance contenha um certo romantismo revolucionário por conta do projeto utópico de construção nacional, através das reflexões da personagem Sem Medo, o autor faz um alerta sobre os problemas futuros que podem minar esse projeto. Um deles é uma possível ditadura do Partido sobre a população. Para o comandante Sem Medo, o que virá depois da libertação colonial, mesmo que seja necessário, não será uma democracia e sim uma ditadura: “Democracia nada, porque não haverá democracia, haverá necessariamente, fatalmente, uma ditadura sobre o povo.” (PEPETELA, 1982, p.124)

Depois de Mayombe, Pepetela escreve em 1972 As aventuras de Ngunga, uma obra produzida com fins didáticos para servir como texto de apoio para as aulas de língua portuguesa nas escolas criadas pelo MPLA para a alfabetização das crianças angolanas. No entanto, a obra acabou sendo publicada no ano seguinte, na forma mimeografada, pelo Serviço de Cultura do MPLA, tornando-se então o primeiro livro publicado pelo autor. 
Conforme observou Pires Laranjeira (1995, p. 145), a obra é "um romance de aprendizagem, um bildungsroman". Ela narra a história de Ngunga, um garoto de 13 anos, cujos pais morrem num ataque dos soldados portugueses durante a guerra de libertação nacional. Órfão, Ngunga acaba por se aproximar dos guerrilheiros, primeiro de Nossa Luta, e depois do comandante Mavinga e do professor União. No decorrer de suas andanças entre os kimbos e as seções militares dos guerrilheiros, ele vai perdendo a inocência e descobrindo aos poucos as imperfeições dos homens: a mentira, a vaidade, a ganância e egoísmo; ao mesmo tempo que lhe cresce o ódio pelo inimigo colonialista. No seu processo de aprendizagem, Ngunga, quando detido numa base militar portuguesa, chega a matar o chefe português, fugindo em seguida com duas armas como espólio para o MPLA. No final da narrativa, troca de nome e desaparece sem deixar vestígios.

Devido à finalidade com que a obra foi escrita, a única novidade que ela apresenta no plano formal é o recurso metaficional, utilizado pelo narrador para encetar um diálogo direto com o leitor e também para explicar o processo de elaboração da história, recurso que o escritor voltaria a utilizar em $O$ cão e os caluandas (1996), Lueji, o nascimento dum império, Jaime Bunda, agente secreto (2003), Jaime Bunda e a morte do americano (2004), Predadores (2008) e A sul. O sombreiro (2011). No mais, a narrativa é estruturada em capítulos curtos, numa linguagem simples e clara para o fácil entendimento das crianças. Já no plano do conteúdo, As aventuras de Ngunga mantêm o mesmo engajamento de Mayombe, pautando-se pelo processo de construção nacional, ao mesmo tempo em que tece algumas críticas a comportamentos inadequados de pessoas do movimento revolucionário, como o velho Kafuxi, que esconde comida para não dar aos guerrilheiros, e também a alguns aspectos da estrutura social africana, como a tradição do alembamento.

Há também outro elemento interessante no romance: a desconfiança em relação à história, manifestada na reflexão feita por Ngunga: 
E Ngunga notou que a mesma história não era sempre contada da mesma maneira. De dia para dia, Mavinga aumentava um pouco ou o número de inimigos mortos ou a dificuldade da operação. (PEPETELA, 1981, p. 22)

E também pelo narrador, na conclusão da obra: "Esta história de Ngunga foi-me contada por várias pessoas, nem sempre da mesma maneira. Tive de cortar algumas coisas que pensei não serem verdade ou com menos interesse." (Ibid., p. 57)

Como sabemos, o processo de reescritura da história através da ficção é elemento essencial no projeto literário do autor, de construção e questionamento da nação, sendo que para isso ele se vale principalmente dos recursos narrativos da polifonia, do contraponto e da metaficção, que lhe permitem questionar a história oficial, mostrando as suas contradições e lacunas, e apresentar outras versões dos fatos históricos, por meio de outras vozes e histórias silenciadas.

\subsection{Duas peças de teatro pelo caminho}

Nos primeiros anos após a independência de Angola (de 1976 a 1978), Pepetela escreveu duas peças teatrais: A corda (1980) e A revolta da casa dos ídolos. Segundo o que próprio escritor nos informa em entrevista a Michel Laban (1991), a opção pelo teatro se deu em razão de ele estar trabalhando no governo de Angola, situação que o deixava quase sem ter tempo para a escrita. Nessa circunstância, o teatro pareceu-lhe mais propício para que pudesse continuar trabalhando com ficção, pois o gênero não demandava a dedicação que o romance exigia.

A corda, escrita em 1976 e publicada em 1978, é uma peça tão explicitamente política que poderíamos, sem nenhum exagero, rotulá-la de panfletária, haja vista a presença no texto do grito de guerra do MPLA: "A vitória é certa". Estruturada em um ato e doze cenas, a peça 
gira em torno do jogo do cabo de guerra disputado por duas equipes: a Revolucionária e a Imperialista.

A equipe Revolucionária é composta por cinco combatentes oriundos de diversos estratos étnicos angolanos, bem como pertencentes a diferentes regiões de Angola: o Kimbundu de Luanda, o Umbundu do Huambo, o Tchokuê de Saurimo, o Mestiço de Cabinda e o Branco do Lubango. Desse modo, Pepetela constrói a equipe como uma metáfora da unidade nacional, forjada a partir da diferença étnica, regional e da cor da pele, sendo que, na hora da apresentação dos integrantes da equipe ao público, todos eles são designados pelo mesmo nome: Povo Angolano.

Já a equipe Imperialista é constituída pelo Americano gordo e sorridente, o silencioso Holden, o traiçoeiro Savimbi, o camaleônico Chipenda e o branco sul-africano Racista; de forma a representar a união de forças dos inimigos de Angola, que ameaçavam constantemente a estabilização do país recém-independente.

Embora a peça seja panfletária e de baixa qualidade literária, ela está em total consonância com o projeto literário do autor de escrever a nação, ao mesmo tempo em que questiona o processo de formação nacional, denunciando tudo aquilo que está dilacerando, ou pode dilacerar, o corpo social angolano. Nesse sentido, o objetivo da peça é levar o público, ou seja, os angolanos, a pensar, tanto que nos intervalos entre uma cena e outra, o narradorpersonagem Likishi, que é também o árbitro do jogo, alerta que os períodos de descanso devem ser utilizados para a reflexão: "Pensem!, não parem de pensar, este combate é feito para vocês pensarem e compreenderem" (PEPETELA, 1980 , p.26), pois assistindo e pensando os angolanos vão perceber que as estratégias utilizadas pelos Imperialistas para a desestabilização dos Revolucionários são a infiltração do separatismo através das intrigas provocadas pelo racismo e o tribalismo, situações que Pepetela já tinha denunciado em Mayombe. Desse modo, fica explícita a mensagem de que a força do povo angolano vem da 
sua união e que conflitos raciais e tribais dentro do grupo só enfraquecem o projeto de construção nacional.

A revolta da casa dos ídolos, escrita em 1978 e publicada em 1980, é uma obra de caráter histórico, pois é ambientada num passado bem distante do momento de sua escrita, retratando um momento importante da história do antigo reino do Congo, ao abordar uma revolta ocorrida em 1514. A partir de escassas informações sobre essa revolta, encontradas na História de Angola, de Henrique Abranches, Pepetela cria um texto dramático em que ela teria sido causada pela proibição do culto animista dos fetiches africanos (ídolos de madeira) feita pelos padres portugueses e seus aliados da aristocracia congolesa. Os objetos apreendidos seriam guardados numa casa para depois serem queimados pelos sacerdotes católicos.

No entanto, o aspecto religioso, que aparentemente é o elemento causador da revolta, rapidamente é sufocado pelo aspecto político, pois Nanga, o protagonista da obra, se transforma num líder popular que busca conscientizar o povo de que a sua força não está nos amuletos africanos apreendidos e sim na união de todos os explorados pela tirania. Ajudado por Masala, um aristocrata dissidente, ele procura mostrar às pessoas que se elas se unirem não haverá mais tirania no reino do Congo. Porém, para que o povo chegue ao poder, conforme o desejo de Nanga, há um grande obstáculo: a aristocracia do Congo representada pelos manis, que manipulam o poder em prol de seus próprios interesses. Para eles, o modelo de revolução propagada por Nanga e Masala não é conveniente, pois traria o fim dos seus privilégios de casta. Através de uma conspiração entre os manis Muxuebata e Mani-vunda, Nanga é assassinado e Masala é preso e enviado como escravo ao Mani-Soyo. Os populares, sem a presença de seus dois líderes, perdem a força e se tornam presas fáceis aos soldados portugueses e assim a revolta é facilmente sufocada. 
Dessa forma, a exemplo da peça anterior, Pepetela aposta na união do povo como única alternativa para acabar com a tirania. No entanto, a profunda análise do poder no antigo reino do Congo realizada pelo autor não fica restrita ao tempo passado, ela pode também ser alusiva ao período contemporâneo de sua escrita, podendo ser relacionada, de forma alegórica, às crises pós-independência pelas quais passou o governo angolano. Na entrevista concedida a Michel Laban, à qual vimos nos servindo desde o início deste capítulo, Pepetela, ao ser questionado sobre as relações entre o escritor e o poder, confirma a escolha do passado como um recurso alegórico para tratar de assuntos políticos contemporâneos sem correr grandes riscos de má interpretação. Segundo ele:

Uma forma de tratar isso de maneira indirecta é ter recurso ao passado situar no passado -, que é o que eu fiz agora, nesse livro que acabei agora (Lueji). Exactamente A revolta da casa dos ídolos é outro exemplo, uma análise do poder, mas situando em outras épocas que podem ser facilmente transpostas para a actualidade, mas sem certos perigos - perigos de má interpretação - porque, realmente, é um tema que é sempre muito quente, que pode ser interpretado de muitas maneiras. (LABAN, 1991, p. 805-806)

Pires Laranjeira, (1995, p. 145) que considera A revolta da casa dos ídolos um "livro importantíssimo para a interpretação do pensamento crítico de Pepetela no tocante à política do seu país", relaciona a obra à tentativa de golpe empreendida pelo dissidente Nito Alves, que culminou no sangrento 27 de maio de 1977, um episódio que deixou cicatrizes profundas na história angolana e um saldo de mais de 20 mil mortos. Levando-se em conta o desfecho trágico da revolta idealizada por Masala e Nanga, com a eliminação dos dois líderes, um assassinado e o outro escravizado, antes mesmo que a revolta acontecesse, é plausível a relação estabelecida por Laranjeira entre as duas tentativas de golpe, separadas por quase cinco séculos.

Dessa forma, Pepetela retoma a utilização da alegoria como recurso narrativo, mas desta vez faz uso dela de uma forma diferente da utilizada em Muana Puó, utilizando-a para abordar problemas contemporâneos através da abordagem de acontecimentos distantes. Vale 
lembrar que a utilização da alegoria com esse mesmo fim vai ser retomada no romance Lueji, o nascimento dum império, e há alguns indícios que o escritor tenha utilizado esse recurso também em A gloriosa família.

\subsection{A retomada dos romances}

Depois de se aventurar pelos textos teatrais, ao deixar o governo angolano, Pepetela retorna ao romance. E pela primeira vez escreve uma obra literária que realmente era para ser publicada, ao contrário das anteriores que escrevera para si mesmo e para a gaveta, ou para servir de apoio para aulas de português, como foi o caso de As aventuras de Ngunga.

Nessa retomada do romance, Pepetela escreve e publica Yaka em 1984, um romance planejado pelo autor para recontar a história de Angola e ao mesmo tempo fazer uma análise da sociedade angolana colonial, no período compreendido entre 1890 a 1975 . Nessa obra, o escritor utiliza diversos recursos narrativos para a sua elaboração, embora, à primeira vista, a narrativa apresente-se como tradicional.

Nesse sentido, Pepetela vale-se de elementos de composição do romance histórico (o entrelaçamento entre ficção e história) para criar uma narrativa de fundação da sociedade angolana, tendo como fio condutor a saga da família Semedo que, metonimicamente, se amplia para a saga da colonização portuguesa em Angola. No entanto, por meio da técnica do contraponto, ele insere no romance uma antissaga através da história dos cuvale, tradicional tribo angolana; e ainda vale-se da polifonia ao utilizar a voz narrativa da estátua yaka para desconstruir ou se contrapor à voz narrativa em terceira pessoa, que narra a história da família de colonos. Também a estátua yaka aparece como uma alegoria da unidade nacional, num 
processo parecido com aquele que o escritor havia utilizado no enigma da máscara de Muana Puó.

Em linhas gerais, por um lado, a obra narra a história da família de Alexandre Semedo, filho de Óscar Semedo, português que foi para Angola degredado, sob a acusação de ter matado a primeira mulher a machadadas, e de dona Esmeralda, considerada portuguesa de segunda por ter nascida em Angola. Alexandre, também português de segunda, casa-se com D. Ana, uma portuguesa pobre, que vem para Angola em busca de um casamento que possa lhe trazer uma condição social melhor. Juntos eles terão três filhos. A partir do crescimento da família Semedo, o clã também passa por um lento processo de ascensão social e econômica, conseguida à custa da exploração da população nativa, através da apropriação de suas terras e da sua força de trabalho. Na parte final do romance, quando acontece a independência, Bartolomeu Sardinha e Matilde Semedo, genro e nora de Alexandre, são colonos ricos, detentores de poder econômico e social na colônia, e o patriarca Alexandre Semedo é o dono do Sapalalo, símbolo do poder colonial português em Angola.

E por outro lado, junto com a história de prosperidade dos colonos portugueses em Angola é mostrada também a história de violência e espoliação que os angolanos sofreram durante o processo colonial. $\mathrm{O}$ trabalho escravo, o roubo das terras, o estupro das mulheres, os massacres em massa de nativos, tudo isso é mostrado como um dos fatores responsáveis pela prosperidade dos colonos a que nos referimos anteriormente. Por isso, o romance tem um teor todo anticolonial. Ele visa, sobretudo, contar a verdadeira história do colonialismo português em Angola e sua derrocada que ocorre na parte final do romance. Dois momentos marcantes da narrativa que refletem toda a exploração sofrida pelos nativos são os massacres do povo cuvale, com o roubo de suas cabeças de gado, e da família do soba Mona, este último narrado pela estátua yaka, que incorpora uma voz coletiva de todos os excluídos pelo poder colonial. 
Juntamente com a história fictícia, são abordados fatos históricos como a expansão portuguesa rumo ao interior da África, após o Tratado de Berlim (1884/1885) e o Ultimato Inglês (1890), a queda da monarquia portuguesa, as duas guerras mundiais, a ascensão do salazarismo, as várias as revoltas dos nativos contra os colonos portugueses, o início da guerra da libertação nacional, a Revolução dos Cravos e os momentos que antecederam a independência angolana em 1975.

Desse forma, Pepetela reescreve a história angolana, o desenvolvimento da colônia que quer tornar-se uma nação independente, formada por cidadãos brancos, negros e mestiços, que se querem angolanos acima de tudo. Por isso as revoltas e as batalhas estão grafadas nas páginas de Yaka (1998), assim como o desejo de forjar uma identidade angolana com os diversos materiais humanos presentes em Angola, aceitando, conforme observação feita por Lourenço do Rosário (2002, p.257), “a contribuição dos vários povos e culturas para a formação do homem angolano" e a complexidade do processo de formação da identidade angolana e dos elementos étnicos envolvidos nele. Para Vima Rossi Martin (2002, p. 297), nas páginas finais do romance fica clara a idéia de que "a história de Angola deve ser construída por todos aqueles que compartilham dos mesmos ideais, não importando raça ou nacionalidade, o texto aposta numa realidade em que as diferenças não serão entraves para aquisição da soberania nacional”.

Em 1985 vem à luz $O$ cão e os caluandas, um livro que começou a ser escrito em 1979 e foi concluído por volta de 1983 (LABAN, 1991). A natureza fragmentada da estrutura narrativa possibilitou que o escritor escrevesse a obra concomitantemente com as suas funções administrativas no governo angolano. Em termos estruturais, sem sombra de dúvida, é a obra do escritor em que há maior utilização de estratégias narrativas, pois é um romance totalmente intertextual, composto por capítulos constituídos por entrevistas, cartas, anúncios e artigos de jornal, peças de teatro e documentos oficiais do governo angolano, tais como ata, 
relatório, memorando, parecer e despacho, que são organizados por um narrador-autor, juntamente com os dez capítulos intitulados "Buganvília" e as intromissões que ele faz no decorrer da narrativa. Sob esse aspecto, essa estrutura intertextual torna o romance paródico, contrapontístico, polifônico e metaficcional.

Outro elemento estrutural que chama a atenção do leitor é o distanciamento temporal que o autor-narrador toma em relação aos fatos narrados, situando a escrita da obra no ano de 2002 e os fatos narrados no início da década de 80 do século XX, ou seja cerca de 20 anos depois, conforme fica explícito no "Aviso ao leitor", logo na abertura do livro, em que há uma espécie de ressalvas para futuras críticas sobre possíveis semelhanças com fatos e pessoas reais.

Em relação ao conteúdo, o romance é também um dos mais interessantes já escritos por Pepetela. Utilizando-se da estratégia de ter como mote a busca por um cão pastor alemão que circula por Luanda, o narrador-autor percorre os vários estratos sociais da capital angolana e vai revelando aos poucos as malandragens e os oportunismos de que vivem os luandenses, mostrando assim os desvios de conduta da população que comprometem o projeto de construção nacional, dando uma consciência infeliz (SARTRE, 2006, p.65) à sociedade angolana pós-independência. Conforme observa Maria Teresa Salgado (2002, p. 300), "à medida que ele (o cão) circula pela cidade de Luanda, vêm à tona as diversas contradições sociais, econômicas, políticas, e/ou afetivas das personagens envolvidas nas situações".

Dessa forma, Pepetela tece uma crítica irônica ao comportamento das pessoas que se renderam ao oportunismo, aos chamados "esquemas", principalmente aos ex-militantes, e implicitamente também critica a burocracia e a estrutura de governo que permitem que tais desvios sejam realizados. Nesse sentido, o professor Benjamin Abdala Júnior (2002) identifica na buganvília, que não para de crescer nos dez pequenos capítulos que ela nomina, a figura do estado burocrático, cujos galhos impedem a consolidação do estado democrático. 
Nesse sentido, podemos estabelecer uma ligação entre a tese implícita contida em Mayombe de que "os homens são mais ou menos condicionados pelas estruturas que eles mesmos criam" (LABAN, 1991, p. 805), ao início da comprovação dessa tese em $O$ cão e os caluandas, que será concluída explicitamente nos romances posteriores A geração da utopia (2000), O desejo de Kianda (2004) e Predadores. Em tempo, lembramos que na entrevista de Pepetela a Michel Laban, ele declara que já havia pensado em utilizar essa ideia determinista em A revolta da casa dos ídolos. No entanto, para isso, a obra teria que ser um romance e não uma peça, e pelo fato de estar no governo não teria tempo para escrevê-lo, situação que o fez abandonar a ideia:

Eu estava com essa ideia na cabeça - essa ideia antiga de Argel, da revolta da casa dos ídolos -, eu queria ir à história - sempre gostei muito de ir à história, buscar coisas. E disse: um romance? (...)

Portanto, sei lá, seria um romance em que, por exemplo, o Nanga, que é o herói - chamemos-lhe positivo - ele, na história é morto. E se não fosse morto? E se a revolta tivesse dado resultado? Bom, os aristocratas tomavam o poder. E se Nanga continuasse e depois tomasse o poder, o que é que se passaria? Ele tornar-se ia aristocrata e tudo ficava na mesma... Fechar o círculo essa era ideia. Mas, como peça de teatro, isso era difícil de realizar... Fiz uma coisa mais linear. Talvez ainda um dia volte a pegar nessa ideia e então criar os círculos para mostrar que, no fundo, a coisa volta e as classes dirigentes reconstituem-se... (LABAN, 1991, p. 795-796)

Dessa forma, o contínuo questionamento do poder que Pepetela faz em seus romances, parece-nos a busca por fechar esse círculo e mostrar que os homens estão presos a determinadas estruturas, das quais eles não conseguem se livrar. E na busca desse objetivo, ele "não hesita em seguir variados caminhos: recorre a mitos, vai às fontes da História, subverte-as; reinventa o passado; e critica, satírica ou acidamente, o presente" (CHAVES, 2005, p. 87).

No seu próximo romance, Lueji, o nascimento dum império, Pepetela recorre à história/mito da rainha lunda Lueji, sobre a qual há várias versões, uma delas, inclusive, feita pelo escritor Castro Soromenho. Servindo-se dessas diferentes versões e também do fato de 
que ninguém sabe ao certo o que realmente aconteceu na Lunda há quatrocentos anos, e nem mesmo se pode ter certeza da existência da rainha, Pepetela se sentiu livre para recriar a história, ou melhor, como ele mesmo diz: criar uma nova versão do mito (LABAN, op. cit., p. 807).

No entanto, Pepetela estabelece uma ponte entre o passado mítico e o período contemporâneo, estruturando o romance com dois tempos históricos: um situado há quatrocentos anos no império Lunda, antigo reino angolano pré-colonial, e outro nos últimos anos do século XX, na cidade de Luanda, capital de Angola. Levando-se em conta que o romance foi escrito em 1988 e publicado em 1989, temos então um tempo passado e um tempo futuro retratados no romance. No tempo passado, a protagonista é a rainha Lueji e no tempo futuro a bailarina $\mathrm{Lu}$, uma provável descendente da rainha, que ensaia um bailado para representar a história da soberana lunda.

Devido a metade do romance retratar um momento importante da história do antigo reino da Lunda, ainda que o fato retratado possa nunca ter existido e ser apenas uma lenda, podemos considerá-la como uma narrativa que utiliza "matéria de extração histórica", conforme a definição de Alcmeno Bastos (2000, p.9) para designar "a matéria objeto de alguma forma de registro documental, escrito ou não, de que resulta permanecer na memória coletiva de uma determinada comunidade".

Nesse sentido, Lueji, o nascimento de um império pode ser considerado um romance histórico, conforme a teorização realizada por Georg Lukács (1966), por ser ambientado num passado distante e retratar uma sociedade angolana pré-colonial, representando literariamente as origens da atual sociedade angolana e assim oferecendo uma "concreta pré-história do presente" (LUKÁCS, 1966, p. 371). O romance também pode ser classificado no que chamamos obras literárias de fundação, que na definição de Lucia Helena (1991, p. 20) são 
"narrativas que se vinculam ao tema da constituição da nacionalidade", pelo fato de buscar na história ou no mito as raízes da identidade e da criação da nação angolana.

No entanto, Pepetela não faz, na abordagem do tempo passado, uma reconstituição social típica do período e da sociedade abordada, enfatizando no texto literário os costumes, as tradições e o modo de pensar dos lundas, características comuns nas obras de caráter histórico e de fundação, às quais relacionamos o romance. O que escritor faz é uma abordagem extremamente política dessa sociedade. A história, lenda ou mito é apenas um pretexto para ele realizar uma profunda análise do poder, uma análise que não fica restrita ao tempo passado, ela pode ser alusiva ao período de vida do autor, podendo ser relacionada, de forma alegórica, aos bastidores do poder do governo angolano pós-independência, conforme Pepetela já havia feito em relação A revolta da casa dos ídolos.

Nesse sentido, pelo fato da obra abordar a luta pelo poder, podemos afirmar, tomando por empréstimo uma expressão utilizada por Irving Howe (1998), que o milieu político é o cenário dominante nela, ou seja, as ideias políticas predominam em relação à história (ou ao mito), ficando esta apenas com a função de elemento causador da reflexão política. Assim, segundo o próprio Pepetela:

Todo o romance é a luta dela para depois passar o poder para o filho: ele, depois, seria o primeiro imperador - aquilo que ela prometeu ao pai moribundo. Mas, no fim, ela habituou-se de tal modo ao poder que acha que o filho já não está em condições de assumir o poder, mas é forçada a ceder... (LABAN, 1991, p. 808)

Em relação à história ambientada no tempo futuro, que corresponde ao período contemporâneo do autor, ela dialoga o tempo todo com a história mítica ou antiga, questionando, principalmente, a veracidade e a confiabilidade da História. No processo de montagem do bailado da rainha Lueji a ser feita pelo grupo de dança de Lu, é constante esse questionamento feito pela bailarina e pela personagem-romancista presente no livro. Nesse sentido, Lueji, o nascimento dum império, além de ter as características já mencionadas de 
romance histórico, romance de fundação e romance político, em relação à abordagem ambientada no passado, no que tange ao seu todo, o romance possui também características do novo romance histórico nos moldes definidos por Seymour Menton (1993), por veicular a ideia borgeana da impossibilidade de se conhecer a verdade histórica e seguir a linha filosófica da história de Nietzsche (WHITE, 1995), para quem havia diferentes visões da história, e por fazer uso da metaficção, através da inclusão de um romancista dentro do romance, que discute concepções de escrita da história e da ficção.

No ano seguinte à publicação de Lueji, Pepetela publica Luandando, um estudo histórico-sociológico sobre a capital angolana, e em 1992 aparece com um novo romance, $A$ geração da utopia, no qual faz um balanço do que foi o movimento revolucionário angolano e dos desvios que os ideais revolucionários sofreram antes e depois da independência angolana, através da abordagem da "trajetória de um grupo de jovens em busca de um sonho comum: a libertação de Angola" (MARINANGELO, 2002, p. 312). Sara, Anibal (Sábio), Vitor (Mundial), Malongo e Elias são alguns desses jovens que vão se desencantar ou se corromper durante esse percurso por 30 anos da história de Angola.

A obra é estruturada em quatro grandes capítulos, todos eles concentrados num determinado período da história recente de Angola, distanciados mais ou menos dez anos um do outro: A casa (1961), A chana (1972), O polvo (1982) e O templo (1991), nos quais

\footnotetext{
O enredo acompanha a gestação, a tentativa de implantação e a falência do projeto utópico que estaria na base da história recente do país e no processo de criação de uma obra cujo eixo gira, como fomos previamente informados, em torno da formação da nacionalidade. (CHAVES, 2005, p. 98)
}

Este romance, que talvez tenha sido o mais polêmico dentre todos os livros escritos pelo autor, marca o início da radicalização do pensamento do escritor em relação ao governo pós-independência. A partir dele, as críticas que antes eram feitas de forma implícita, através do uso da alegoria ou da crítica a comportamentos individuais errados, desvinculados da 
estrutura de poder, passam a ser críticas explícitas à estrutura de poder que substituiu o governo colonial português. Nos dois capítulos finais, há uma crítica feroz e direta aos abusos cometidos por uma classe aristocrática e privilegiada que se fornou no governo do MPLA, cujo principal representante é a personagem Vitor Ramos, ex-revolucionário que se torna um ministro de estado corrupto.

Em contraposição a Vitor, está Anibal, um ex-guerrilheiro que se desencanta com os rumos da revolução e vai viver num exílio voluntário em Benguela. No trecho abaixo, numa conversa com Sara, ele tece um comentário duro sobre o que eles foram e o que hoje eles são, lamentando a degradação ética e moral ocorrida mesmo antes de chegarem poder:

Costumo pensar que a nossa geração se devia chamar a geração da utopia. Tu, eu, o Laurindo, o Vitor antes, para só falar dos que conheceste. Mas tantos outros, vindos antes ou depois, todos nós a um momento dado éramos puros e queríamos fazer uma coisa diferente.

Pensávamos que íamos construir uma sociedade justa, sem diferenças, sem privilégios, sem perseguições, uma comunidade de interesses e pensamentos, o Paraíso dos cristãos, em suma. A um momento dado, mesmo que muito breve nalguns casos, fomos puros, desinteressados, só pensando no povo e lutando por ele. E depois...tudo se adulterou, tudo apodreceu, muito antes de se chegar ao poder. Quando as pessoas se aperceberam que mais cedo ou mais tarde era inevitável chegarem ao poder, cada um começou a preparar as bases de lançamento para esse poder, a defender posições particulares, egoístas. A utopia morreu. E hoje cheira mal, como qualquer corpo em putrefacção. Dela só resta um discurso vazio. (PEPETELA, 2000, p. 240)

Nesse sentido, o romance retoma a ideia contida em Mayombe, de que o movimento revolucionário carregava dentro de si o ovo da serpente do poder, a qual Pepetela pensou em retomar para a escrita de A revolta da casa dos ídolos em forma de romance, quando pretendeu fazer com que Nanga, ao invés de morrer como acontece na peça, tomasse o poder e também se tornasse aristocrata, ficando tudo do mesmo jeito que estava antes da revolução e só mudando os nomes dos dirigentes. Assim o autor pretendia "mostrar que, no fundo, a coisa volta e as classes dirigentes reconstituem-se..." (LABAN, 1991, p. 795-796). Essa ideia do caráter cíclico da reconstituição das classes dirigentes já está bem nítida no início do romance: 
"Portanto, só os ciclos eram eternos" (PEPETELA, 2000, p. 9), e na análise irônica que Anibal faz do sistema político de países pobres ou subdesenvolvidos, ao ser indagado por Orlando, se não pensava em ter uma atividade política:

\begin{abstract}
Para dizer a verdade, tinha vontade de criar o MMP, Movimento dos Marginalizados do Processo. Como único programa, ser oposição ao futuro governo eleito, qualquer que seja. Porque marginalizados só podem ser oposição, nunca ganham eleições, mesmo sendo a esmagadora maioria da população. Se por um azar o Movimento conseguisse ter a maioria dos votos, o que correspondia a uma impressionante tomada de consciência do povo, dissolvia-se automaticamente para não ser corrompido pelo uso do poder. Mas como bom intelectual angolano, não tenho capacidade para pôr em prática essa bela idéia. (PEPETELA, 2000, p.366)
\end{abstract}

A análise cética e irônica de Aníbal toca no nervo da questão: o poder corrompe e para se manter puro só mesmo mantendo-se distante dele.

Dessa forma, no começo do romance há a imagem da utopia no período de início do movimento revolucionário, e na outra ponta, há a distopia, finalizando o texto e o sonho utópico de uma sociedade mais justa idealizada pelo movimento revolucionário angolano. No entanto, a utopia persiste, não mais como fruto de um programa de partido ou de um movimento revolucionário e sim nas relações humanas, conforme afirma Tania Macêdo (2006, p. 85), ao observar que "a utopia se desenha na caracterização do jovem casal Judite e Orlando".

Em $O$ desejo de Kianda, Pepetela segue a mesma trilha aberta pela $A$ geração da utopia e aprofunda ainda mais a crítica política feita no romance anterior ao governo angolano. A obra, escrita entre os anos 1994 e 1995, está fortemente marcada pelos acontecimentos que abalaram a sociedade angolana da primeira metade dos anos 90, quando o fracasso das eleições presidenciais e a consequente retomada da guerra civil desencadearam uma violenta desestruturação social, conforme observa a professora Tania Macêdo (2002). Nesse sentido, podemos considerar este romance como uma continuação do último capítulo de A geração da utopia, "O tempo (a partir de julho de 1991). 
A narrativa é ambientada na cidade de Luanda, especificamente no largo do Kinaxixe e arredores, local em que, no período colonial, existia uma lagoa que fora aterrada para a construção de um prédio, onde acreditava-se que fosse a morada da Kianda, o ser mítico das águas que habita o imaginário luandense/angolano; e é estruturada com duas histórias que se complementam através da técnica narrativa do contraponto.

No primeiro plano está a história do casal Carmina Cara de $\mathrm{Cu}$ (CCC) e João Evangelista e o desabamento de prédios dos arredores do largo do Kinaxixe; e em segundo plano, encaixada na primeira, está a história do canto da Kianda, ouvido apenas pela menina Cassandra, pelo mais velho Kalumbo e pelo narrador.

Dessa forma, na crônica da Angola do início dos anos 90, o narrador aborda a história de um casal nada convencional. Ele (João Evangelista), filho de religiosos e educado numa missão religiosa do Huambo, se torna um alienado no decorrer da narrativa, só se preocupando com jogos virtuais e com a satisfação sexual da esposa; e ela (Carmina), uma mulher mandona que ascende da condição de militante da Jota (Juventude do MPLA) a membro do Comitê Central (CC) do MPLA, chegando ao cargo de deputada e daí à empresária que se beneficia do estado angolano, que, conforme a observação feita por Tania Macêdo,

... ao realizar a abertura da economia ao capital, abre caminho aos fraudadores e ao "esquema" (corrupção). Nesse sentido, Carmina passa de militante de esquerda, marxista, a "importadora" de armas e de cerveja, amealhando riqueza e utilizando-se de seus conhecimentos no parlamento para obter ainda mais benesses. (MACÊDO, 2002, p.321-322)

Vale lembrar que a partir da ascensão de Carmina ao Comitê Central do MPLA, os nomes de ambos acabam por se identificar: Carmina Cara de $\mathrm{Cu}(\mathrm{CCC})=$ Comitê Central (CC).

No entanto, a cada ascensão econômica ou política de Carmina um prédio dos arredores do largo do Kinaxixe desaba, a começar pelo seu casamento com João Evangelista, 
financiado pela máquina governamental. Dessa forma, há uma relação metonímica de causa e efeito, conforme o próprio narrador informa no início da narrativa, vista por Maria Thereza Abelha Alves (2002) como duas metáforas: a da conjunção, que corresponde aos sucessos de Carmina; e a disjunção, o desabamento dos prédios, fenômeno chamado de "síndroma de Luanda". Nesse sentido, "a cada um de seus sucessos na senda da corrupção e da fraude, corresponderá o desmoronar de mais um prédio no Kinaxixe, de tal forma que a narrativa vai construindo a contraposição entre a ascensão da corrupção e a queda dos edifícios" (MACÊDO, 2002, p. 322).

Outra metáfora interessante usada pelo narrador é a da comida. Conforme bem observa Maria Thereza Abelha Alves (2002), os negócios corruptos e os planos de enriquecimento ilícito de Carmina são discutidos e comunicados à mesa, durante o almoço ou o jantar, de forma que o apetite dela é proporcional ao seu apetite pelos lucros. Nesse sentido, lembramos que essa metáfora já havia sido utilizada em A geração da utopia, quando Anibal, numa conversa com Sara, refere-se aos ex-revolucionários corrompidos como "possuidores dum apetite voraz, insaciável" (PEPETELA, 2000, p. 241), e seria retomada em Predadores, cujo título já remete a seres que destroem outros seres, animais ou vegetais, para se alimentarem. Em comum esses três romances têm também o fato de que a corrupção brota diretamente do aparelho governamental.

No entanto, apesar de todo o desencanto que há no final de $O$ desejo de Kianda, cujo ápice se dá na destruição parcial de Luanda, também nesse romance Pepetela não mata a utopia. Ela sobrevive na história do canto de liberdade da Kianda, só ouvido pelas personagens marginais, aquelas afastadas das estrutura do poder, de modo que "os dois últimos fragmentos da lenda prometem a libertação e ensejam uma nova utopia" (ALVES, 2002, p. 217) 
Em Parábola do cágado velho, romance publicado em 1996, Pepetela deixa momentaneamente o espaço romanesco da cidade de Luanda e a crítica corrosiva à corrupção do aparelho estatal angolano, presentes nos dois romances anteriores, para voltar-se ao interior de Angola e às tradições tribais, e criticar de forma alegórica a guerra fratricida entre UNITA e MPLA.

Nesse sentido, a história de amor entre Ulume, homem maduro com filhos adultos, e a adolescente Munakazi, e a briga entre os dois filhos de Ulume (Luzolo e Kanda), que se colocam em lados opostos da guerra, representam o significado aparente da narrativa, e mal disfarçam o significado subjacente que conduz à crítica ao absurdo da guerra civil angolana que, por décadas, matou ou mutilou milhares de pessoas, atrasando e inviabilizando, juntamente com a corrupção instalada no aparelho estatal, o projeto de construção nacional.

No entanto, além do diálogo com a história contemporânea de Angola, confrontandose muitas vezes elementos da tradição com os da modernidade, o narrador também revisita tanto a história antiga quanto a história recente angolana, acabando por concluir que ela sempre foi marcada pelas guerras e pela fome:

Nesta terra sempre passaram guerras. (...) Ganhava um ou outro, o certo é que muita gente morria. Durante a guerra não se podia cultivar. Os celeiros ficavam vazios, a fome vinha. (...) Sempre foi assim, desde os avós dos avós. (PEPETELA, 2005, p. 13).

Para exemplificar, o narrador cita vários conflitos: as guerras tribais entre sobas para ampliação de território, as guerras de kuata-kuata para apanhar escravos quando os portugueses chegaram, a guerra da independência, e por último a guerra civil. E a fome sempre presente, como uma eterna companheira da guerra a assolar os homens.

Dessa forma, conforme observa Carmen Tindó (2002), Pepetela elabora uma antiepopeia das guerras angolanas, destituindo-as de qualquer tipo de heroicidade e ufanismo, que são atributos das epopeias modernas, e realça os sofrimentos do povo, que é a principal 
vítima dos conflitos bélicos. Nesse aspecto, é significativo o diálogo de Ulume com um dos filhos, em que fica bem nítido que, embora alguns ganhem com a guerra, no final todos perdem.

Mas havia uma pergunta que há muito lhe perfurava a cabeça e resolveu fazê-la a Kanda:

- Tu sempre foste esperto, por isso podes me explicar. Quem ganhou com esta guerra? Tu talvez tenhas ganho, pelo menos parece pelo aspecto. $\mathrm{O}$ teu irmão não tem nada. Quem ganhou, eu não sei. Quem perdeu, isso eu sei, fomos nós todos.

Kanda baixou pela primeira vez os olhos. O osso da garganta mexeu, como se tentasse engolir qualquer coisa. (PEPETELA, 2005, p. 113)

Desse modo, conforme acertadamente observa Magdala França Vianna (2002, p.328), Pepetela "com determinação política, constituída em nome de um universal ético humanista, denuncia as guerras irracionais que retalharam o país."

Em 1997, pelo conjunto de sua obra, Pepetela é agraciado com Prêmio Camões, e nesse mesmo ano, com a publicação de A gloriosa família: o tempo dos flamengos, retorna mais uma vez à história antiga de Angola, e, por essa razão, esse romance, além de estar plenamente ajustado ao seu projeto literário, se insere, principalmente, na linha das narrativas de fundação da nacionalidade que o autor inicia com Yaka e depois dá continuidade com Lueji, o nascimento dum império, e, como veremos no final deste capítulo, retoma com o seu romance mais recente, $A$ sul. $O$ sombreiro.

A gloriosa família tem como protagonista o holandês Baltazar Van Dum, uma personagem histórica de segunda linha, cuja referência Pepetela encontra na História geral das guerras angolanas, do português António de Oliveira Cadornega. Tendo como mote a ficcionalização dessa personagem sobre a qual se sabe muito pouco, o escritor aborda o período compreendido entre fevereiro de 1642 a agosto de 1648, um período histórico importante na vida angolana que corresponde à dominação holandesa, colocando a personagem-protagonista "presente em quase todas as cenas, de forma nuclear ou subsidiária, 
que retratam as articulações e conchavos políticos com os governantes holandeses, portugueses e congoleses" (TEIXEIRA, 2002, p. 339).

Ao contrário do que se possa pensar, Baltazar é um holandês aportuguesado e católico que já vivia em Luanda há mais de 20 anos quando os holandeses chegaram, e no jogo de interesses que se estabelece no decorrer da narrativa está muito mais para o lado dos portugueses do que para os seus patrícios, com os quais também mantém relações amistosas. Vivendo do tráfico de escravos, que era o principal comércio na colônia na época, ele havia constituído uma numerosa família mestiça, formada por filhos do quintal, concebidos com as escravas, e por filhos da casa grande, gerados com dona Inocência, uma nativa que é a sua esposa oficial. Daí então a origem do título, A gloriosa família, que remete para a representação metonímica da fundação da sociedade angolana, tendo por base a mestiçagem biológica e cultural, vistas através do desenvolvimento de uma família. De acordo com Ana Mafalda Leite:

Van Dum, emblema de uma "gloriosa" família, vai, antes e depois, sobreviver sempre prosperamente, em Luanda, à custa do seu negócio de tráfico de escravos para o Brasil. Nos doze capítulos do romance são apresentados os conflitos flamengo-portugueses, a diversidade de actuações no domínio militar, religioso e cultural, as políticas comerciais, a teia de corrupção e de influências e jogos de intriga que, durante sete anos, percorrem a geografia luandense, através, fundamentalmente, das estratégias oportunas do protagonista Van Dum e da sua interminável família mestiça. (LEITE, 2002, p. 140-141)

Embora não haja a abordagem da sucessão de gerações da família Van Dum, devido à abordagem sincrônica do curto espaço de tempo de seis anos, o romance termina com a previsão de Matilde, filha de Baltazar, de que no futuro os Van Dum seriam uma família gloriosa. Nesse sentido, classificamos essa obra também como uma saga familiar, filiando-a à linha seguida por Pepetela em Yaka e Lueji, o nasimento dum império a exemplo do que fizemos anteriormente em relação ao estatuto de narrativa de fundação. 
No entanto, nesse romance, Pepetela adota uma estratégia de dessacralização da história bem mais radical que a realizada nos dois romances precedentes. Ele vai parodiar e desconstruir a história oficial através de um narrador em primeira pessoa (um narradortestemunha), que é escravo, mudo, analfabeto e sem nome. Ou seja, é um do deserdados e literalmente é um dos silenciados pela história. Desse modo, conforme aponta Valéria Maria Borges Teixeira (2002, p. 339), "com esse recurso literário, o texto de Pepetela denuncia, por meio da voz do escravo, todas as incongruências e violências derivadas do processo de colonização holandesa e portuguesa em Angola", ao mesmo tempo em que conta uma outra versão da história, a história dos vencidos, vista da perspectiva daqueles que nunca tiveram voz e nem espaço nos livros de história, que coloca em xeque a veracidade da história oficial.

O narrador, escravo de Baltazar Van Dum, acompanha o seu dono por todos os lados e por isso configura-se como uma testemunha ocular da história, e mesmo os acontecimentos aos quais é privado de presenciar, ele cinicamente confessa que preenche essa lacuna com a imaginação, numa clara alusão ao modo como os historiadores preenchem as lacunas da história, como acontece, por exemplo, no episódio em que Baltazar vai à sede da Companhia das Índias Ocidentais se explicar ao diretor holandês Nieulant, e ele fica do lado de fora aguardando a saída dono.

Tudo o que possa vir a saber do ocorrido dentro do gabinete será graças a imaginação. Sobre este caso e sobre muitos outros. Um escravo não tem direitos, não tem nenhuma liberdade. Apenas uma coisa lhe não podem amarar: a imaginação. Sirvo-me sempre dela para completar relatos que me são sonegados, tapando os vazios. (PEPETELA, 1999, p. 14)

O escravo-narrador também dialoga diretamente com todos os textos históricos que servem de epígrafe aos doze capítulos do romance, mas concentra-se, principalmente, na História geral das guerras angolanas, de António de Oliveira Cadornega, transformando o autor em personagem do romance e "criticando a concepção de história do militar e a crónica oficial lusitana, segundo a qual somente os acontecimentos louváveis e heroicos deveriam ser 
narrados" (TEIXEIRA, 2002, p. 343), conforme fica nítido no trecho abaixo em que Ambrósio, filho de Baltazar conversa com Cadornega:

Diga-me, senhor alferes. Falou em registrar por escrito o que vai observando. Está a escrever um livro sobre estes acontecimentos?

- Ainda não. Por enquanto, só tenho apontamentos dispersos. Penso contar a história heroica dos portugueses nesta terra, desde a fundação da cidade de Luanda. Por isso pergunto detalhes aos que viveram as coisas e registo o que me contam.

- E vai apresentar o governador Sottomayor da maneira como fala dele aqui entre amigos? Porque li algumas crónicas e até poemas sobre os reis e heróis de Portugal, que só cantam coisas sublimes e grandiosas, como se não existissem as menos gloriosas.

(...)

- Chega a ser uma questão moral. Se escrevo sobre as grandezas de Portugal, como posso contar as coisas mesquinhas? Não, essas ficam no tinteiro, pois não interessam para a história. Será necessário saber interpretar a crónica. Personagem que não aparece revestida de grandes encómios é porque não prestava mesmo para nada e só o pudor do escritor salvaguarda a sua memória. Assim se tem feito, assim deve ser. (PEPETELA, 1999, p. 269)

Dessa forma, Pepetela subverte completamente o discurso histórico português, colocando em dúvida a veracidade dos fatos narrados pela história oficial, ao mesmo tempo em que oferece uma outra versão dos fatos ocorridos durante aqueles anos de dominação holandesa em Angola.

Outro aspecto deste romance ainda não explorado, é que os jogos de influência, as articulações e os conchavos políticos que se estabelecem entre portugueses, holandeses e congoleses são extremamente atuais, principalmente as atitudes oportunistas de Baltazar Van Dum, o que pode ser caracterizado também como uma alegoria da neo-burguesia, a classe predadora que se formou em Angola após a independência, que Pepetela criticou duramente em A geração da utopia e $O$ desejo de Kianda.

Três anos depois de A gloriosa família e do Prêmio Camões, Pepetela ressurge na cena literária com a publicação de A montanha da água lilás (fábula para todas as idades) (2007), um livro aparentemente inocente que à primeira vista pode parecer uma narrativa para crianças e adolescentes, apesar do subtítulo indicar que é uma obra para qualquer idade. No 
entanto, como em Pepetela nada é gratuito, a fábula também pode ser lida como uma alegoria da sociedade angolana dos anos 90 .

A fábula narra a história de uns simpáticos animais cor de laranja que habitavam uma montanha. Esses seres, denominados de lupis, possuíam duas pernas e dois braços e andavam eretos como os humanos, viviam em casais, habitavam em casas feitas de folhas e ramos de árvores e se alimentavam somente de frutas. Havia dois tipos de lupis, embora pertencessem à mesma espécie: os lupis cambutinhas, de tamanho menor, "mais rápidos a aprender, mais vivos, inventavam coisas e estórias, canções e danças" (PEPETELA, 2007, p. 33); e os lupões, maiores e mais lentos não inventavam, "mas como trabalhavam muito e eram sérios, sabiam fazer melhor as contas de dividir as mangas, ou de somar goiabas com pitangas" (Ibid.). Os casais de lupis podiam ter filhos cambutinhas ou lupões, independente da qualidade dos pais, sendo que ao nascer todos eram iguais e só na fase de crescimento é que se distinguiam os lupões dos cambutinhas.

Eles viviam em harmonia numa sociedade coletora, onde todos tinham a sua função social. Por isso, todas as personagens lupis são personagens-tipos: havia a lupi-professora, o lupi-poeta, o lupi-comerciante, o lupi-sábio, o lupi-advogado, o lupi-armazenista, o lupicontabilista e o lupi-kimbada, entre outros. O primeiro acontecimento a quebrar essa harmonia foi o surgimento de uma nova qualidade de lupis: os jacalupis. Maiores que os lupões, eles eram gulosos e preguiçosos, fato que obrigou cambutinhas e lupões a trabalharem mais para poder alimentá-los, pois os jacalupis não subiam nas árvores para apanhar frutas e possuíam "um apetite devorador" (Ibid., p. 34) e com o tempo começaram a se tornar agressivos e a desrespeitar todas as regras e convenções dos lupis.

O segundo acontecimento foi o surgimento repentino de uma pequena fonte de água lilás na montanha. A princípio, a água escura e perfumada, só trouxe benefícios à sociedade dos lupis. O aroma era relaxante e o banho fazia desaparecer as carraças (carrapatos) que 
infestavam o corpo dos lupis, bem como aliviavam a coceira provocada por elas. No entanto, não tardou muito para que a água lilás chamasse a atenção dos animais que viviam fora da montanha, fato que provocou o início de um comércio entre os lupis e os animais da planície, envolvendo a troca da água por frutas, e assim termos como negócios, lucros e clientes, antes desconhecidos, passaram a fazer parte do vocabulário dos lupis.

O resultado dessa abertura comercial foi a total desestabilização da sociedade dos lupis, pois muitos passaram a ser carnívoros, a maioria desaprendeu a subir nas árvores para apanhar frutas e acabaram por se tornar uma sociedade consumista, principalmente os jacalupis, cujo apetite era cada vez maior. Nesse sentido, acertadamente observou Ana Luisa Ventura Vieira Pereira (2009, p. 325) que a fábula é uma "parábola absoluta da liberalização da economia, sintetizada nas lutas pela posse e uso da água lilás". Dessa forma, podemos relacionar o sentido alegórico subjacente dessa aparentemente inocente fábula à crítica contida nos romances $A$ geração da utopia e $O$ desejo de Kianda à emergência de uma neoburguesia predadora a partir da abertura da economia ao capital, metaforizada no apetite feroz de Mundial e Carmina, apetite de igual proporção ao dos jacalupis.

Em 2001, Pepetela surpreende os seus leitores com a publicação de um romance policial: Jaime Bunda, agente secreto. Uma paródia angolana do James Bond, de Ian Fleming. Dois anos depois, em 2003, o autor repete a experiência e publica Jaime Bunda e a morte do americano. Nesses dois romances, Pepetela usa e abusa da sátira, da ironia, da comicidade e das experiências formais, principalmente em relação ao foco narrativo, num exercício metaficcional contínuo que até permite ao autor demitir determinado narrador que não esteja correspondendo ao seu papel estrutural.

O agente Jaime Bunda, cujo sobrenome/apelido vem do seu descomunal traseiro, nem de longe lembra a sua matriz inglesa. Conforme bem observa Rosangela Manhas Mantolvani (2009, p. 334), o herói, ou melhor o anti-herói de Pepetela, é "ladino, mentiroso, comilão e 
desleixado, desestruturado, mal-preparado, amoral, mal-amado e acaba surrado por uma mulher", bem ao contrário do detetive inglês "que é temido e invejado pelos inimigos e desejado por todas as mulheres." Além disso, Jaime Bunda é também "pouco preocupado com a questão da justiça e profundamente dedicado a viabilizar sua ascensão profissional e social pela lei do mínimo esforço" (Ibid., p. 333).

Como em todo romance policial deve haver um crime, Jaime Bunda, agente secreto (2003) aborda o assassinato de uma garota de 14 anos na ilha de Luanda, que serve de abertura para a investigação de um crime financeiro de altas proporções que envolvem pessoas influentes do governo, como o inominado e tenebroso senhor T; enquanto que Jaime Bunda e a morte do americano gira em torno do assassinato de um engenheiro norteamericano, que estava em Benguela a serviço de uma empresa multinacional, e da história do Robin dos Comboios, um ladrão angolano que só roubava passageiros da primeira classe.

No entanto, o crime ou a trama policial é só um mote para Pepetela abordar outras questões mais sérias e urgentes (embora a tônica dessas duas narrativas seja o humor) que envolvem a sociedade angolana contemporânea às suas escritas, conforme o próprio autor informa em entrevista à Doris Wieser (2005), ao declarar que o romance policial "é só um pretexto para analisar a sociedade", de modo que julga os seus livros como falsos "romances policiais", considerando que neles o conteúdo policial é "o menos importante. Importante é levar o leitor à sociedade de Luanda ou pelo menos a algumas camadas da sociedade". Nesse aspecto, observa Rosangela Manhas Mantolvani, tomando por base Jaime Bunda, agente secreto:

A estrutura social é, assim, "reproduzida", em alguns momentos, na estrutura da obra.

Suas críticas se estendem aos detetives e à polícia secreta angolana, permeadas pelo bom humor, enquanto ironicamente denuncia todos os desmandos, corrupções, tramoias, clientelismo e abusos de poder praticados por investigadores, chefes, diretores e subchefes das instituições de segurança. Em sua crítica ferina, o texto inclui, também, alusões a figuras do meio político, ao governo, empresários, "trambiqueiros", traficantes e 
meliantes em geral. Por meio dessas personagens, revela e critica, implicitamente, as futilidades de suas preocupações diárias em face do momento caótico que atravessa o país. (MANTOLVANI, 2009, p. 332-333)

Desse modo, mesmo nesses romances satíricos e paródicos Pepetela mantêm como o seu principal objetivo a preocupação de fazer com que o seu leitor, principalmente o leitor angolano, tome consciência da estrutura da sociedade e reflita sobre ela. Nesse sentido, conforme observa a professora Simone Caputo Gomes (2009, p. 343), "a desconstrução do gênero policial faz parte, portanto, de uma estratégia para operar uma leitura alegórica da sociedade angolana em tempos pós-coloniais globalizados, de diluição de utopias (...)."

Uma das críticas mais ferinas e irônicas feitas por Pepetela nesses dois romances é a teoria do PGL, o Perdão Generalizado aos Ladrões, que se encontra em Jaime Bunda e a morte do americano, na qual, pelo voz de Julião Domingos de Sousa, o vate de Benguela, o autor propõe a legalização do roubo do erário público realizado pela classe predadora angolana, desde que ela parasse de roubar e ajudasse a combater os desvios de dinheiro público e investisse no país todo o capital roubado.

Vamos dizer-lhes, perdoamos os vossos roubos como Cristo nos ensinou a perdoar a quem nos tem ofendido. Mas vocês vão ajudar-nos, com a vossa experiência na rapinice, a evitar que outros sigam o vosso exemplo. Para vosso sossego e para o nosso bem. A partir de agora, nós e os nossos ladrões, vamos garantir que se roube menos e o que for apanhado a roubar vai mesmo para a cadeia. Não só os pequenos larápios de esquina, mas os grandes predadores de smoking. Vai para a cadeia o grande tubarão que meteu no bolso duas fábricas e cinco fazendas, mais dez milhões de dólares aqui e outros cinquenta dali. Não só o desgraçado que pilhou umas moedas ou uns pães numa loja. Vão todos kuzuo. E vamos dizer mais aos nossos grandes ladrões: agora o vosso dinheiro vem para cá, invistam no país, passa a ser dinheiro limpo e protegido. Reconhecemos a vossa propriedade perpetuamente, mas invistam na terra. Construam casas, fábricas, criem fazendas, dêem empregos... Esta é a minha proposta: a sociedade decreta o Perdão Generalizado e partimos para a moralização do país e o seu desenvolvimento. (PEPETELA, 2004, p. 251)

Dessa forma, Jaime Bunda, agente secreto e Jaime Bunda e a morte do americano, apresentam muito mais que uma simples e humorada paródia de James Bond. Apesar do tom 
de brincadeira e aparentemente descompromissado, eles seguem fielmente o projeto literário do autor.

Em Predadores, romance publicado em 2005, Pepetela retoma o tom cáustico e amargo que caracterizou o discurso de A geração da utopia e $O$ desejo de Kianda e faz uma análise profunda do regime político angolano pós-independência, certamente a mais completa que já fez, sendo que o próprio título já nos remete aos seres que destroem os outros para se alimentarem deles, numa clara alusão a todos aqueles que se corromperam e deram continuidade a um sistema injusto de exploração do povo, formando em Angola aquilo que o autor denomina "classe predadora". Logo no início do romance, ao utilizar um recurso narrativo característico de algumas de suas obras, o recurso metaficcional da intromissão do autor na narrativa, cortando (e muitas vezes desautorizando) o discurso do narrador, Pepetela já deixa transparecer a fúria de sua crítica política ao utilizar palavras de baixo calão para caracterizar o protagonista da obra e tudo aquilo que ele representa no contexto angolano: “ $E$ desde já previno, este não é um livro policial, embora trate de uns tantos filhos de puta." (PEPETELA, 2008, p. 21)

O romance é estruturado através da técnica narrativa do contraponto e num primeiro plano narra a história da ascensão social, econômica e política de Vladimiro Caposso que, beneficiado por um jogo de influências junto às esferas de poder, torna-se um poderoso empresário em Angola. Num segundo plano, mas não menos importante, em contraste com a vida da família burguesa do empresário e seus aliados políticos e comerciais, desfilam pela obra diversas personagens que vivem à margem desse universo de luxo e corrupção: o advogado idealista Sebastião, que não se deixa seduzir pelos cantos de sereia das conveniências políticas; a família de Nacib, o menino pobre que vence na vida através da educação e do bom caráter; meninos de rua (Kasseke e Manuel) e mutilados de guerra (Simão Kapiangala). Dessa forma, Pepetela representa na narrativa, através dessas personagens, 
vários estratos sociais angolanos, contrastando uma minoria exploradora e corrupta a uma grande maioria explorada e honesta.

A obra é estruturada em 20 capítulos nominados em numerais arábicos sequenciais e cobre um período de tempo de 30 anos, que vai de novembro de 1974 a dezembro de 2004. Porém essa sequência não é linear. Dispondo esses capítulos com uma rubrica que identifica o tempo narrado, como se fosse um diário, o narrador conduz a narrativa intercalando, muitas vezes, capítulos distanciados no tempo um do outro. Através dessa intercalação de diversos tempos históricos, o narrador constrói a trajetória de Vladimiro Caposso, situando a narração em momentos capitais da vida da personagem em consonância com a história angolana.

O capítulo 1 já nos apresenta Vladimiro Caposso como um conhecido e poderoso empresário angolano ligado ao partido no poder, no momento da abertura política que se esboçou em 1992 com a realização de eleições diretas. Assim o narrador nos apresenta uma personagem já corrompida moralmente e que pratica um crime, ao assassinar a sangue frio a amante e o homem que estava com ela, enquanto que na rua acontecia uma passeata política por conta da proximidade da eleição. Os flashbacks explicativos sobre a vida de Caposso só vão aparecer a partir do capítulo 4, situado em novembro de 1974, quando ele era ainda um jovem pobre e sem a ambição que o caracterizaria nas décadas posteriores.

No capítulo seguinte (5), que marca o início da ascensão de Caposso, quando ele entra para o partido e ganha do patrão português a loja em que trabalhava, aparecem os primeiros sinais de corrupção dentro do governo do MPLA, quando procura os meios legais para regularizar a posse da loja. A corrupção surge, anos depois, de forma institucionalizada como uma prática comum em Angola, quando o empresário tenta subornar a polícia para tirar da cadeia seu filho Ivan, que tinha atropelado Simão Kapiangala, um pobre mutilado de guerra como tantos em Angola, abandonados pelo governo. No final do romance vamos encontrar um Vladimiro Caposso que perde parte de seus negócios e prestígio social e político em 
Angola, mas ao fim e ao cabo não tem do que reclamar, pois durante o tempo em que esteve em lua de mel com os detentores do poder juntou muito dinheiro, guardado com toda segurança em bancos suíços.

No entanto, apesar de todo o desencanto e acidez do romance, a exemplo do que acontecera em A geração da utopia e $O$ desejo de Kianda, a utopia de uma sociedade mais justa não morre: ela sobrevive na história do menino Nacib e do advogado Sebastião que fazem o contraponto à história de Vladimiro Caposso. Nesse sentido, observa Vima Lia Martin:

... o romance também explicita uma outra história tecida na contramão das práticas oficiais. Esta história a contrapelo, protagonizada por personagens que transitam num universo social pautado por valores mais humanos e inclusivos, acaba por revelar a convicção do autor de que é possível resistir à força daqueles que, por disporem de uma autoridade institucionalizada, impõem suas próprias definições de si mesmos e dos outros. (MARTIN, 2009, p. 35)

\subsection{A fuga ao espaço e à temática angolana}

Em O terrorista de Berkeley, Califórnia (2007) e O quase fim do mundo (2008), livros publicados em 2007 e 2008, Pepetela rompe com a linha mestra que pautou a sua escrita literária até então, a tematização de Angola, e se aventura por outras paragens além das fronteiras angolanas. Por essa razão, para os leitores familiarizados com os seus romances, a leitura dessas duas obras foi, certamente, uma surpresa, pois elas fogem por completo ao espaço e a temática angolana, algo caro ao escritor até então. Habituados à leitura de romances que retratam ou falam sobre Angola, os leitores se deparam com narrativas externas aos assuntos angolanos. Terrorismo, aniquilação da humanidade, fanatismo religioso, experiências científicas, paranóia, entre outros. 
O terrorista de Berkeley, Califórnia, uma novela de 115 páginas que possui o mesmo tom paródico dos dois Jaime Bunda, tem como cenário a cidade norte-americana de São Francisco e é uma sátira à paranoia do terrorismo que se abateu sobre os Estados Unidos após o atentado terrorista de 11 de setembro de 2001. Composto em seis capítulos, a obra narra a desventurada história de Larry, um solitário e superdotado acadêmico norte-americano da Universidade de Berkeley, que um dia resolve, para fugir da solidão, criar um correspondente imaginário na internet, a quem poderia "contar os seus pensamentos mais íntimos" (PEPETELA, 2007, p, 47).

Servindo-se de diferentes computadores da universidade, Larry passa a veicular, em tom de brincadeira, mensagens de revolta contra o mundo até que um dia escreve um e-mail para o seu correspondente imaginário explicando a necessidade de explodir a ponte Golden Gate, o maior ícone da costa ocidental norte-americana. Essa brincadeira inofensiva de Larry, concebida apenas para exorcizar seus fantasmas e preencher seus momentos de solidão, é rastreada pelo serviço de inteligência norte-americano. O teor dessas mensagens cai como uma bomba na sede do Grupo Especial de Combate ao Terrorismo para a região de São Francisco.

A partir daí a paranoia norte-americana por conta do terrorismo vem à tona. Todo o aparato tecnológico do Serviço de Inteligência é acionado, e desfilam pelas páginas do romance agentes secretos e especialistas em informática, transformando a narrativa em uma brincadeira de gato e rato. Nesse sentido, segundo Sueli Saraiva (2009), esse livro que é um convite à reflexão sobre o nosso tempo relata:

... uma inversão que é nuclear ao enredo: a humana modernidade do protagonista, aliada a sua genialidade em lidar com as avançadas tecnologias, choca-se no ciberespaço com a implacável barbárie de uma condenação sem julgamento protagonizada por Estado moderno e democrata. (SARAIVA, 2009, p. 359) 
Assim como já havia feito nos dois romances da série Jaime Bunda, Pepetela explora ao máximo o jogo entre o sério e o cômico, oferecendo ao leitor uma leitura leve e agradável, mas que também pode (e deve) levar à reflexão. A obra, através da sátira, tece uma crítica à era Bush e suas políticas de (in)segurança interna e também ao American way life, pois, lembrando a declaração feito pelo autor à Doris Wieser (2005), o romance policial (satírico ou não) é só um pretexto para analisar a sociedade em que foi gerado. Nesses tempos de insegurança e incerteza do início do século XXI, a obra nos permite refletir sobre até que ponto uma sociedade com medo pode reagir à ameaças reais ou imaginárias.

Em $O$ quase fim do mundo, publicado em 2008, Pepetela deixa o espaço norteamericano e retorna à África, mas não a Angola. O enredo do romance é o misterioso desaparecimento de quase toda a vida animal da face da Terra. O livro narra a aventura de um grupo de doze pessoas que sobrevive ao hecatombe: o médico Simba Ukolo, a religiosa Geny, a adolescente Judy, o ladrão Joseph Kiboro, o garoto Nkunda (sobrinho de Simba), o pescador (o único personagem sem nome no romance), o misterioso sul-africano Jan Dippenaar, a cientista norte-americana Janet Kinsley, o mecânico Julius, o feiticeiro etíope Riek, a bela historiadora somali Ísis, e um louco que mudava constantemente de nome.

Com os conhecimentos de aviação de Dippenaar, eles aventuram-se por outras localidades na tentativa de encontrar mais pessoas e respostas para o que tinha acontecido com mundo. Primeiro viajam à cidade de Nairobi, no Quênia, e a encontram vazia. Depois vão à Europa. Perambulam por Paris e Roma e também não encontram nenhum ser vivo. No entanto, no território europeu, descobrem que o desaparecimento da humanidade foi causado por uma experiência científica levada a cabo pelos Paladinos da Coroa Sagrada, a religião de dona Geny.

Daí a constatação de que a vida tinha se extinguido em todo o mundo, exceto numa pequena parte da África, e não é por coincidência que Pepetela situa a fictícia Calpe próxima 
à região onde acredita-se ter sido o berço da humanidade. Assim, embora o romance pareça inicialmente ser pura ficção, totalmente descompromissado com a realidade, na verdade é bem o contrário. O escritor só aparentemente abandona o engajamento que é tão característico em suas obras. O romance é uma grande metáfora da resistência africana diante do descaso dos países do primeiro mundo. E é justamente essa desimportância que possibilita que essas pessoas escapem do holocausto, evitando assim que a humanidade fosse completamente aniquilada. Por ironia do destino, caberia ao continente mais desprezado do planeta reiniciar e reconstruir a história da vida na Terra.

No entanto, esse reinício vai contemplar a repetição de alguns erros já cometidos pela humanidade. Conforme observa Raquel Silva (2009, p. 369), o romance " tem como pano de fundo para sua narrativa a tessitura de uma nova humanidade que não aprende com os seus erros", ao referir-se ao trecho em que esboça-se a criação de uma nova classe dominante entre os sobreviventes:

- É mesmo bom que o Riek convença as pessoas a virem - disse Julius. - Para produzirem comida...

- Enquanto nós mandamos e comemos - disse Janet, em voz sumida.

Dippenaar ouviu-a, no entanto. Apoiou com a cabeça, é isso mesmo que vai acontecer, sempre foi assim, uns trabalham, outros mandam. (...)

- Seremos a classe dominante - disse o sul-africano. - Há dúvidas? (PEPETELA, 2008, p. 378)

É o mito do eterno retorno que Pepetela incorpora à sua literatura. Aqui vale relembrar que a ideia do caráter cíclico da reconstituição das classes dirigentes (LABAN, 1991) está na base da análise sociopolítica que ele fez da sociedade angolana.

Por essa razão, $O$ terrorista de Berkeley, Califórnia e $O$ quase fim do mundo destoam da rota literária percorrida pelo escritor até então. Embora o estilo seja o mesmo, utilizando, inclusive, expressões linguísticas angolanas, e a primeira obra seja descendente direta dos dois Jaime Bunda, desaparecem por completo o espaço e a preocupação com os rumos de Angola. 
Dessa forma, nessas duas obras, os temas de Pepetela deixam de ser nacionais para se tornarem universais. Saem de cena o questionamento político da realidade angolana e a utopia e a distopia em relação à construção nacional e entram o terrorismo e a preocupação com o poder de destruição do ser humano que pode levá-lo à destruição de si mesmo. Exemplos no mundo contemporâneo não faltam: terrorismo; armas nucleares, químicas e biológicas; destruição da camada de ozônio; fanatismo religioso; alta tecnologia com fins destrutivos e outras tantas formas de destruição da natureza.

Certa vez, numa entrevista, Pepetela disse que o seu desafio era levar os angolanos a serem capazes de pensar (CHAVES; MACEDO, 2002, p. 38), pelo fato de sua literatura ser voltada para análise da realidade sócio-histórica angolana. No entanto, em O terrorista de Berkeley, Califórnia e $O$ quase fim do mundo, ele transcende o espaço angolano e sua preocupação volta-se para a humanidade inteira. São obras capazes de levar à reflexão não só o leitor angolano, mas também o leitor de qualquer nacionalidade ou continente.

\subsection{O retorno ao espaço e à temática angolana}

Em O planalto e a estepe (2009), romance publicado em 2009, Pepetela volta a utilizar a matéria de extração histórica angolana ao contar a história do amor impossível entre o angolano Júlio Pereira e a mongol Sarangerel, tendo como pano de fundo a história do movimento revolucionário angolano.

Júlio Pereira é um jovem angolano branco da Huíla que vai estudar Medicina em Coimbra no início dos anos 60, e lá, em contato com o pessoal da Casa dos Estudantes do Império, começa a se politizar. Essa politização resulta no abandono da faculdade e no engajamento na luta de libertação nacional. Ele não é enviado diretamente ao front de batalha 
e sim contemplado com uma bolsa de estudo em Moscou. Lá conhece Sarangerel por quem se apaixona e a partir daí, em meio aos acontecimentos históricos e políticos mundiais, a narrativa se transforma na luta de Júlio para poder ficar ao lado de sua amada.

O grande obstáculo ao casamento entre os dois jovens é um tema já abordado pelo autor em Mayombe: o racismo. Mas, desta vez, ele não fica restrito ao espaço angolano como fora feito na obra anterior. Agora a abordagem do racismo parte de uma perspectiva nacional e chega a uma perspectiva universal. Se, no início da narrativa, ele aparece condicionado às nuances angolanas, como, por exemplo, o fato de não haver negros na escola onde Júlio estudava ou ainda de que o motivo para ele não ter sido enviado diretamente ao front de batalha tivesse sido por ser branco e esses, aos olhos do movimento de libertação nacional, "ainda não eram suficientemente angolanos para arriscarem a vida na luta pela nação" (PEPETELA, 2009, p. 33), a partir do terceiro capítulo, "Luar em Moscovo", o racismo toma proporções universais por ser o grande obstáculo para a concretização da união entre Júlio e Sarangerel, pelo fato de ele ser angolano e ela mongol, embora os seus países de origem se considerassem unidos pela irmandade do socialismo universal difundido pela então União Soviética. Nem a gravidez de Sarangerel seria capaz de remover tal obstáculo.

Nesse romance, Pepetela também atrela a história angolana à história do mundo, algo inédito até então. Nesse sentido, o projeto de libertação nacional e construção da nação angolana está diretamente ligado à política de expansão do comunismo promovida pela União Soviética. Nas palavras de Jean-Michel, personagem pelo qual o autor expressa muitas vezes suas próprias ideias, a exemplo do que fez anteriormente com Sem Medo de Mayombe e Anibal de A geração da utopia: "Existia uma grande orquestra de muitos partidos e movimentos de libertação, todos ditos irmãos, e o maestro estava ali no Kremlin. (PEPETELA, 2009, p. 44) 
O diálogo com a história e o questionamento político que, no início, a exemplo do racismo, aparecem restrito ao contexto angolano, agora também transcendem este contexto e adquirem feições mundiais. O jogo político não é mais uma queda de braço entre colonizados angolanos e colonizadores portugueses ou entre os angolanos explorados e a elite predadora angolana, e sim entre o socialismo soviético, que estendia seus tentáculos com a política do internacionalismo proletário na tentativa de fomentar movimentos que levassem à criação de mais repúblicas socialistas aliadas, e o imperialismo americano, que tentava conter a expansão soviética; e ainda entre a União Soviética e a China, com a Mongólia pelo meio.

Dessa forma, ao mesmo tempo em que conta uma bela história de amor, Pepetela também está fazendo uma crítica aos regimes socialistas, expondo toda a hipocrisia de um discurso que era um na teoria e outro na prática. Percorrendo os bastidores da política internacional, Pepetela descortina todas as contradições e incoerências do socialismo mundial, não poupando o Kremlin e todas as repúblicas socialistas.

Se compararmos $O$ planalto e a estepe, O terrorista de Berkeley, Califórnia e $O$ quase fim do mundo, e também à produção literária anterior a essas obras, constataremos que esse romance marca o retorno do escritor ao locus angolano sem deixar de lado a temática universal contida nos dois romances precedentes, pois tanto o racismo quanto a política são abordados num contexto internacional.

No romance A sul. O sombreiro, publicado em Portugal em setembro de 2011, Pepetela revisita novamente a história antiga de Angola, como já havia feito anteriormente em A revolta da casa dos ídolos, Yaka, Lueji, o nascimento dum império e A gloriosa família e produz uma outra narrativa de fundação da sociedade angolana. Dessa vez o romancista retorna ao início do século XVII, bem no começo da colonização portuguesa, quando Luanda ainda era um esboço de cidade e Benguela estava para ser fundada, e período também em que Portugal se encontrava em poder da Espanha. O alvo principal de Pepetela é figura histórica 
de Manuel Cerveira Pereira, ex- governador da colônia de Angola e fundador da cidade de Benguela.

Na ficcionalização feita por Pepetela, Manuel Cerveira Pereira, depois de muitos abusos de poder frente ao governo da Angola, na época um território que compreendia apenas a região de Luanda, é preso e enviado a Lisboa, acusado de assassinatos, torturas, roubos do erário público e dos colonos, e, pasmem, até da sedução de 25 das 50 mulheres portuguesas casadas residentes na colônia. Mas, apesar de todas essas acusações, valendo-se dos seus relacionamentos familiares em Portugal e, principalmente, da fortuna acumulada em Angola, ele não apenas foi absolvido pelo rei Filipe II como também foi recebido pelo monarca em Madri e nomeado, em 1612, Governador e Conquistador do Reino de Benguela, com o objetivo de encontrar as fabulosas minas de cobre, que mais tarde se revelariam inexistentes.

Com uma tropa formada basicamente por algumas dezenas de adolescentes e mais alguns soldados recrutados em Luanda, Manuel Cerveira Pereira chega a região em 1615 e funda a cidade com o nome de São Filipe de Benguela. Devido a localização da cidade numa região pantanosa, fato que provocava malária numa escala muito maior que em outros lugares, e os abusos de poder do governador, que administrava a nova colônia com mão de ferro, Cerveira Pereira enfrentou constantes rebeliões internas, vingando-se cruelmente dos rebelados, até ser expulso também de lá. Entretanto, novamente dá a volta a por cima e retoma o governo da colônia.

Mas o romance não fala somente de Manuel Cerveira Pereira. Utilizando-se da técnica do contraponto, Pepetela insere no livro a história do aventureiro Carlos Rocha, um angolano mulato, bisneto de um dos capitães da expedição de Diogo Cão, que teria engravidado uma nativa durante a histórica viagem que o comandante português empreendeu à foz do rio Kongo em 1482. 
Carlos Rocha foge de Luanda com medo que o pai o vendesse como escravo e empreende uma perigosa fuga pelo interior de Angola, tendo como companhia o escravo Mulende e um mosquete. No seu percurso pelo território angolano, ele trava relações com o aventureiro inglês Andrew Battell, de quem se torna amigo, e com os temíveis jagas, guerreiros sanguinários que eram, na época, o pesadelo tanto dos portugueses quanto dos demais povos africanos que habitavam a região. Entretanto, utilizando-se de astúcia e muita coragem, Carlos Rocha torna-se aliado deles e chega até se casar como uma mulher jaga, e no final acaba ludibriando-os ao fugir com a esposa e não pagar pelo seu alembamento, que era nada mais nada menos que a oferta de um escravo para ser comido no banquete nupcial. $\mathrm{O}$ final das aventuras de Carlos ocorre justamente na baia de Benguela, local para onde também se dirigia Manuel Cerveira, o outro herói do romance.

A sul. O sombreiro pode ser enquadrado como um novo romance histórico, conforme a acepção de Fernando Ainsa (1991) e Seymour Menton (1993), ou então como uma metaficção historiográfica, de acordo com a concepção de Linda Hutcheon (1991), pelo fato de ficcionalizar uma personagem histórica e realizar uma irônica e crítica releitura da história, através da qual desmitifica a imagem de figuras históricas canônicas como as dos reis D. Sebastião e D. Filipe II; mostra as contradições e a crueldade do processo colonial português e espanhol, amparado numa falsa missão civilizadora, e revela a hipocrisia da Igreja Católica, eterna parceira dos estados ibéricos na expansão ultramarina, cujo discurso da preocupação com a salvação da alma dos nativos se contrastava com as suas atitudes materialistas.

Nesse sentido, o romance oferece ao leitor uma outra perspectiva histórica, ou seja, outras versões do fato histórico, a partir do ponto de vista de quem sofreu o silenciamento durante séculos de dominação colonial ou mesmo de quem foi agente da história, mas é visto a partir de dentro ou por olhares que o desnudam, numa perspectiva nietzschiana da história 
que, segundo Hayden White (1995), não concebia "uma única verdade histórica” mas sim "verdades históricas".

Para tanto, Pepetela lança mão de algumas estratégicas narrativas já utilizadas em seus livros anteriores. A primeira delas é a técnica do contraponto, recurso que permite elaborar a obra com duas histórias paralelas que se harmonizam na configuração do todo do romance, a de Manuel Cerveira e a de Carlos Rocha, que o autor vai orquestrando através do processo de alternância, ora interrompendo uma ora retomando a outra. Uma outra estratégia é a utilização de diversos narradores, o que dá à narrativa um caráter extremamente polifônico, pois essas vozes são todas independentes umas das outras. Ao todo, cinco narradores povoam o romance. E uma terceira estratégia narrativa é o recurso metaficcional da intromissão do autor no livro, grafada em itálico e entre colchetes, cortando em muitos momentos a voz dos narradores para acrescentar uma informação histórica com um comentário não raro irônico ou ácido, como é característico do escritor.

Desse modo, com esse romance, Pepetela fecha até o momento o seu projeto literário, no qual é perfeitamente possível entrever uma linha de coerência que vem desde os seus primeiros escritos. A sua grande temática é Angola: a construção dessa nação, a busca das raízes fundadoras, o questionamento desse processo de construção nacional e dos desvios que ele teve no percurso histórico. Mas o objetivo do seu projeto de escrita não é apenas escrever sobre Angola, recontando a sua história e denunciando todo tipo de violência, abuso de poder e roubalheiras que a nação e o povo angolanos sofreram tanto no período colonial quanto no período pós-independência. O grande objetivo do seu projeto literário, aquilo que o motiva a escrever, é escrever sobre Angola para levar os seus leitores à reflexão, principalmente os leitores angolanos.

Nesse sentido, ele elabora a sua escrita como um meio de ação que é só concebível e útil "em função dos seres aos quais esta ação concerne" (CARPENTIER, 1971, p. 91), ou 
seja, a sua ação escrita se dá em prol dos leitores e do mundo em que ambos (autor e leitor) vivem, de modo que ela é permeada por um projeto ético fiel à sua visão de mundo e ao seu compromisso social e humano de despertar consciências. Por isso, no melhor estilo sartriano (SARTRE,2006), Pepetela procura desvendar o mundo, ou melhor, a sociedade angolana ao seus leitores. 


\section{YAKA: UMA SAGA FAMILIAR E UMA NARRATIVA DE FUNDAÇÃO ENGAJADA}

\subsection{Uma narrativa de fundação engajada}

Conforme vimos no capítulo anterior, Pepetela inicia o seu percurso como escritor em circunstâncias históricas específicas, estando engajado no movimento revolucionário angolano na luta pela independência do país, primeiramente trabalhando no Centro de Estudos Angolanos em Argel e depois estando diretamente no front de batalha na Frente Leste. Desse modo, conforme ele próprio afirma (LABAN, 1991), os seus primeiros romances foram escritos a partir de uma necessidade pessoal e coletiva e por isso dialogavam diretamente com o momento histórico em que estava vivendo. A necessidade pessoal vem do fato de que Pepetela precisava escrever para poder refletir e compreender melhor os problemas e as contradições que emergiam no seio do grupo revolucionário, e a coletiva porque o resultado dessa escrita/reflexão seria utilizado nas aulas de formação política que o escritor ministrava aos guerrilheiros, visando levá-los também à reflexão e à conscientização sobre os problemas que enfrentavam no processo revolucionário.

Nesse aspecto, essa escrita atendia a uma necessidade didática urgente daquele contexto histórico e correspondia também a uma tomada de posição diante daquela realidade vivida, conforme a concepção do engajamento do intelectual de Jean-Paul Sartre (2006) e Edward Said (2005). Daí então que suas obras escritas naquele período foram publicadas somente após a independência de Angola ocorrida em 1975, exceção feita a As aventuras de Ngunga.

No entanto, depois de consumada a independência política de Angola, acontecimento que, segundo Mário César Lugarinho (2007), promoveu a literatura angolana da condição de 
"contraliteratura" (MOURALIS, 1982) ao posto de literatura nacional, e diante da necessidade de se construir e consolidar, simultaneamente, uma nação e uma literatura angolana, tarefa que se apresentava de modo urgente aos escritores angolanos da geração de Pepetela, conforme observou Rita Chaves em A formação do romance angolano (1999), cabia representar literariamente a formação da nação angolana, através de narrativas que fossem buscar no passado as origens da sociedade que estavam a construir, e aí então entra o romance de fundação no projeto literário do autor ${ }^{14}$, inserindo-se ele na corrente literária da "tradição romântico-realista de escrever a nação por meio da ficção" (HELENA, 2005, p. 168-169).

Em entrevista concedida à professora Maura Eustáquia de Oliveira, Pepetela comenta a necessidade que as literaturas das nações em formação têm de ir buscar as raízes nacionais e transformá-las em temas de reflexão.

Quando as nações como Angola estão a viver uma fase de formação e afirmação da sua identidade, a literatura tem uma certa intenção de explicar suas raízes, de encontrar respostas a questões fundamentais como: quem somos? Onde estamos? Nesse momento, a referência histórica torna-se importante no contexto da literatura. Isso explica, talvez que o meu tema principal e recorrente é sempre a nação. Esse é meu leitmotiv. (OLIVEIRA, 2003, p. 367)

Ou seja, conforme observa Edward Said (1995, p. 13), a literatura, sobretudo a narrativa de ficção, após ter sido utilizada durante séculos pelos impérios coloniais, torna-se nos períodos da descolonização e pós-independência o instrumento utilizado pelos povos colonizados para afirmação da identidade e da existência de uma história própria deles.

É com esse objetivo que Pepetela vai escrever e publicar o romance Yaka (1998), uma obra plenamente engajada no processo de construção nacional, na qual o escritor angolano

\footnotetext{
14 Aqui vale lembrar que embora Pepetela seja o principal representante da narrativa de fundação angolana, ele não foi o primeiro escritor a cultivar esse gênero em Angola. Esse posto cabe a Manuel Pedro Pacavira que em 1979 publicou Nzinga Mbandi, um romance sobre a história da lendária rainha Nzinga.
} 
elabora "uma literatura que, mesclando, registro e invenção, intensifica aquele desejo de saber de que barro somos feitos. " (CHAVES, 2005, p. 83).

E nessa busca pelo barro de que são feitos os angolanos, conforme observa a professora Rita Chaves (Ibid., p.87), Pepetela "recorre a mitos, vai às fontes da História, subverte-as, reinventa o passado", pois, para ele, "criar, através da literatura, insere-se no mito unificador de Angola, no ideal de reunir etnias e ideologias em torno da construção/reconstrução do país" (OLIVEIRA, 2003, p. 363). Desse modo, além de buscar fontes históricas referentes à colonização portuguesa em Angola, Pepetela vai também em busca dos mitos angolanos para encontrar um "mito unificador/fundador" de Angola, conforme declara a Maura Eustáquia de Oliveira:

Os mitos que povoam Angola são preservados pelos grupos étnicos que ocupam as diferentes regiões do nosso território. Conheço-os da experiência que tenho junto à população rural e ando à procura do mito que reconstrua Angola, pois tem de haver um mito para construir uma identidade nacional e é nessa busca que me perco ou me encontro... (OLIVEIRA, 2003, p. 367)

O romance Yaka, escrito em 1983 e publicado em 1984, foi a primeira narrativa de fundação escrita por Pepetela e também a primeira tentativa de encontrar o mito fundador/unificador da nação. Yaka, a estátua africana que dá título a obra, exerce esse papel de "mito unificador", explicitando no texto a voz da consciência coletiva africana e, principalmente, segundo o próprio Pepetela (LABAN, 1991, p.802), representa um ponto comum em direção à unidade nacional angolana, aquilo que ele denomina de "cazumbi ${ }^{15}$ antecipado da nacionalidade (PEPETELA, 1998, p. 14). Para construir essa imagem de uma alegoria da unidade, Pepetela buscou fontes pré-coloniais, utilizando como ponto de partida (explicitada em nota prévia na obra) a história dos jagas (ou yakas), um povo que teria percorrido todo o território angolano, "pontuando um percurso que se tornou nacional, mais

${ }^{15}$ Cazumbi: espírito. 
tarde" (LABAN, 1991, p. 802-803), estabelecendo chefias por toda parte e, dessa forma, representaria um bom exemplo da unidade e identidade angolana, que poderia ser recriado através da ficção. Vejamos uma parte da nota prévia do romance sobre os jagas:

Yaka, Mbayaka, jaga, imbangala?

Foram uma mesma formação social (?), Nação (?) - aos antropólogos de esclarecer. Certo é que agitaram a já tremeluzente História de Angola, com suas incursões ao Reino do Congo (...) Na Matamba, deram força à legendária Rainha Njinga (ou Nzinga), que empurrou o exército português até o mar. Talvez Njinga fosse yaka? A hipótese ainda não morreu. Os ditos guerreiros, que por comodidade chamo de yaka, desceram para o sul e já no Centro ocidental de Angola aprisionaram o inglês Battel que deles conta coisas de estarrecer - (...). Tiveram influência certa no dito Reino de Benguela, formaram chefias nas terras dos Muila, Gambo, já lá bem no Sul, irrequietamente voltaram a subir, formaram chefias no Planalto, em Caconda, Huambo, Bailundo, Bié...

E o círculo yaka ficou fechado nesses séculos antigos.

Criadores de chefias, assimiladores de culturas, formadores de exércitos com jovens de outras populações que iam integrando na sua caminhada, parecem apenas uma ideia errante, cazumbi antecipado da nacionalidade.

Mas não é deles que trata este livro, só duma estátua.

E a estátua é pura ficção. Sendo a estatuária yaka riquíssima, ela poderia ter existido. Mas não. Por acaso. Daí a necessidade de a criar, como mito recriado. Até porque só os mitos têm realidade. E como nos mitos, os mitos criam a si próprios falando. (PEPETELA, 1984, p.6)

Na história engendrada por Pepetela, a estátua de origem jaga ou yaka, que o pai de Alexandre Semedo ganhou no jogo, exerce um duplo papel: é uma alegoria da nação enquanto corpo que está sendo formado a partir da conscientização do povo, e por esta razão ela se apresenta como um enigma para Alexandre Semedo que só será revelado no final da narrativa pelo seu neto Joel, momento em que o patriarca já está angolanizado, e ao mesmo tempo é a voz coletiva angolana, que ao assumir a voz narrativa narra com total onisciência, denunciando as violentas práticas colonialistas e reforçando a esperança de todos os que sofreram tais abusos e violências.

Mas além de utilizar a estátua yaka como um mito fundador/unificador da angolanidade, como uma alegoria da unidade nacional, o romance também tinha outro propósito: fazer, através da ficção, um análise da sociedade colonial portuguesa em Angola, 
procurando "identificar no passado as causas para o que veio depois" e investigando o "processo pelo qual, lentamente, essas causas começaram a produzir seus efeitos", conforme a observação feita por Umberto Eco (1985, p. 76) sobre o romance histórico. Nesse sentido, Pepetela afirma numa entrevista ao professor Carlos Serrano (1999) que essa análise poderia explicar muita coisa da atual e da futura sociedade angolana, sendo que esse lançar de luzes sobre o período colonial em Angola também serviria para que as novas gerações, que não viveram a situação colonial, soubessem como foi o colonialismo e como era a mentalidade do colono. Segundo Pepetela:

A preocupação principal era a seguinte, e que portanto tem importância talvez para o futuro, é que me parece, exceto Castro Soromenho, não há ainda na ficção uma análise da sociedade colonial. Ora, há muita coisa de Angola de hoje e de Angola de amanhã que encontram explicação nessa sociedade. Porque apesar da luta de libertação, apesar da independência, etc., muita coisa ficou fundamentalmente em termos do que se pode chamar muito genericamente de cultura, incluindo comportamentos sociais, preconceitos, etc. Há uma série de reações que tiveram que são explicadas pela história colonial. Há trajetórias individuais de pessoas que só podem ser explicadas pela educação que receberam em determinado meio. Depois houve a ruptura. A independência é uma ruptura, um trauma de que se recuperam numa nova sociedade, mas com muita coisa que vem de trás. (SERRANO, 1999, p. 138)

Ao encontro da preocupação de Pepetela em relação às influências do colonialismo sobre a atual sociedade angolana, vem a observação feita por Rita Chaves sobre os efeitos que a situação colonial provocou no continente africano:

O peso das relações fundadas a partir da ocupação portuguesa se arrastou e ainda repercute no presente, seja sobre a sua realidade diária, seja sobre os bens simbólicos ali gerados e/ou que circulam. Sem receio de cair no excessivo, podemos afirmar que de tal forma os esquemas coloniais penetraram na composição sociocultural do continente que se torna difícil elaborar qualquer análise sobre qualquer que seja o objeto, sem passar pela indagação da natureza e dos efeitos do colonialismo naquelas sociedades. (CHAVES, 2005, p. 288)

Como dizia Frantz Fanon (1979), as marcas deixadas pelas ações colonialistas nos povos africanos colonizados são múltiplas e muitas vezes indeléveis. Para Pepetela, essas 
marcas deixadas pela colonização são visíveis nos comportamentos dos indivíduos angolanos após a independência, como, por exemplo, o hábito de se comer bacalhau na noite de Natal deixado pelos portugueses em Angola, um tema que o autor abordou numa de suas crônicas $\operatorname{angolanas}^{16}$, e na vida em geral das pessoas e seus valores culturais, fato que fez Pepetela ver Luanda como uma cidade mestiça, que é africana mas também é europeia em muitos aspectos.

Uma outra preocupação do autor na composição dessa obra era mostrar a possibilidade de que alguém que fizesse parte da sociedade colonial pudesse angolanizar-se a ponto de participar ativamente da guerra contra os sul-africanos, como fez Joel, personagem do romance.

Dessa forma, guiado pela preocupação de preencher lacunas históricas (e lacunas na própria ficção angolana), tematizar a formação da nação e da identidade angolana, buscando encontrar os mitos fundadores de Angola, e analisar a sociedade colonial para refletir e compreender melhor os aspectos sociais e culturais da sociedade pós-independência, Pepetela planejou escrever Yaka, uma romance que tendo como fio condutor a saga de uma família de colonos portugueses abordaria um período de quase 100 anos da história angolana, especificamente os últimos anos da colonização portuguesa em Angola. A esse respeito, em entrevista a Michel Laban, o escritor comenta as dificuldades que teve para levar a cabo o projeto de escrever uma saga da nação:

O primeiro livro que foi pensado antes de ser escrito. (...) foi sistematizado antes. Todos os outros são idéias que se desenvolvem à medida em que vou escrevendo. O Yaka não, foi sistematizado antes. Talvez por isso tenha sido o livro mais difícil de escrever e que me tenha dado menos gozo - já não havia muitas surpresas... Esse problema pôs-se logo de princípio, quando eu pensei no livro, que tinha que ser um tempo largo, mas que pensava que seria aborrecido, que haveria muitos pontos mortos se pegasse uma linha de continuidade... Portanto, resolvi situá-los em cinco momentos, excepto a primeira parte que é numa linha mais contínua - a parte da infância, em que tinha que haver uma certa continuidade - mas, a partir daí, situar em momentos precisos, que eram momentos significativos da própria história da

\footnotetext{
${ }^{16}$ PEPETELA. O bacalhau do Natal. In. Crônicas com fundo de guerra. Lisboa: Norton de Matos, 2011.
} 
região... Portanto, situar revoltas, fundamentalmente. (LABAN, 1991, p. 800)

Ao voltar-se aos mitos angolanos e ao passado colonial em busca das raízes nacionais, Pepetela, que já tinha a formação da nação angolana como o tema principal do seu projeto literário desde o primeiro romance, Muana Puó, mas antes voltada ao passado recente ou ao período contemporâneo, incorpora ao seu projeto literário a narrativa de fundação, seguindo um modelo iniciado pelos romancistas do século XIX "de escrever a nação por meio da ficção" (HELENA, 2005, p. 168-169), voltando-se ao passado nacional distante, conforme já nos referimos anteriormente. No entanto, ao fazê-lo, o escritor rompe com o modelo tradicional cultivado pelos escritores românticos e realistas, ao incorporar elementos do engajamento literário do século XX à narrativa de fundação, através da denúncia da violência colonial e do contar de uma outra história, que se contrapõe à história oficial portuguesa, a história dos vencidos, conforme a concepção de Walter Benjamin (1985) sobre a história e a escrita alegórica. Nesse aspecto, as narrativas de fundação escritas por Pepetela se aproximam do conceito de "romance histórico de resistência" concebido pela professora Vera Follain de Figueiredo:

O romance histórico de resistência voltou-se contra a visão universalizante da história segundo um paradigma ocidental, denunciando as falácias desse discurso tido como científico, mas, ao tentar criar uma outra história, se contrapondo à versão oficial, revelou também, de certa forma, uma crença na história, não mais como verdade única mas como conflito de versões no qual cabe afirmar a visão dos vencidos. Ao travar uma luta contra o esquecimento promovido pelo poder e fazer emergir os aspectos do passado que haviam sido silenciados pelas representações oficiais, é ainda a história que sai engrandecida - mas uma outra história, que uma vez resgatada, tem em si um potencial utópico. (FIGUEIREDO, 1997, p. 483)

É desnecessário dizer que o conceito de "romance de resistência" estabelecido por Vera Figueiredo, por realizar uma releitura crítica da história e dar voz a tudo o que foi silenciado pela história oficial, é muito semelhante ao conceito de "novo romance histórico 
latino-americano" de Fernando Ainsa (1991) e Seymour Menton (1993), haja vista que os seus principais exemplos de romances históricos de resistência são as narrativas de Alejo Carpentier, Augusto Roa Bastos, Gabriel Garcia Marquez e Carlos Fuentes ${ }^{17}$, embora se distancie, principalmente da concepção de Seymour Mentor, por flexibilizar o distanciamento temporal da narrativa histórica, ao mesmo tempo em que se aproxima do conceito de "metaficção historiográfica", de Linda Hutcheon (1991, p. 127-146), pelo fato de considerar a história, assim como a ficção, como um discurso, um construto humano, e por isso passível de carregar em seu bojo "verdades no plural, e jamais uma só verdade", conforme a filosofia nietzscheana da história que, segundo Hayden White afirma:

\begin{abstract}
O escopo de Nietzsche era destruir a crença num passado histórico no qual os homens pudessem aprender qualquer verdade única e substancial. Para Nietzsche, como para Burckhardt, havia tantas "verdades" acerca do passado quantas fossem as perspectivas a respeito dele. (...) Os homens encaravam o mundo por ópticas que se harmonizavam com os propósitos que os motivavam; e exigiam diferentes visões da história para justificar os vários projetos que deviam empreender a fim de realizar plenamente sua humanidade. Basicamente, portanto, Nietzsche dividia as maneiras como os homens encaravam a história em dois tipos: um tipo negador da vida, que pretendia encontrar o único modo eternamente verdadeiro, ou "correto", de considerar o passado; e um tipo afirmador da vida, que estimulava tantas visões dissímeis da história quantos projetos houvesse de alcançar uma consciência de si nos seres humanos individuais. (WHITE, 1995, p. 340)
\end{abstract}

Nesse contexto, insere-se a narrativa de fundação engajada, ou de resistência, elaborada por Pepetela, que preenche as lacunas e os silêncios deixados pela história oficial, iluminando os desvãos e ouvindo as vozes silenciadas pelo processo colonial português, e assim apresenta um outro lado da história, a história dos vencidos que, ao final, acabam-se por se tornar também vencedores. Nesse sentido, embora a narrativa de Yaka guie-se pela história já escrita ${ }^{18}$, por apresentar essas características ela se aproxima em parte da

\footnotetext{
${ }^{17}$ Entre os escritores brasileiros que escreveram narrativas históricas de resistência, Vera Figueiredo cita Antonio Callado, Erico Verissimo, João Ubaldo Ribeiro e J. J. Veiga.

${ }^{18}$ Para a escrita do romance, Pepetela se valeu das informações históricas contidas em História das campanhas de Angola (1986) do historiador René Pelisier.
} 
metaficção historiográfica de Linda Hutcheon, ainda que Pepetela não seja exatamente um escritor pós-moderno, e apresenta algumas das características identificadas por Fernando Ainsa (1991) no novo romance histórico latino-americano, como as que seguem citadas abaixo, conforme veremos na análise da polifonia e do contraponto presentes no romance.

1 - O novo romance histórico caracteriza-se por fazer uma releitura crítica da história;

2 - A releitura proposta por esse romance impugna a legitimação instaurada pelas versões oficiais da história. Nesse sentido a literatura visa suprir as deficiências da historiografia tradicional, conservadora e preconceituosa, dando voz a tudo aquilo que foi negado, silenciado ou perseguido pela história;

3 - A multiplicidade de perspectivas possíveis faz com que não haja uma só verdade do fato histórico. A ficção confronta diferentes versões que podem ser até mesmo contraditórias.

(...) (ESTEVES, 1995, p. 29-30)

Ao representar literariamente e criticamente o povo e a nação angolana, Pepetela também encarna o papel que o escritor cubano Alejo Carpentier (1971) defendia para o romancista latino-americano, por transformar o seu povo e a sua terra em objeto de reflexão literária, agindo também como "o homem colonizado que escreve para o seu povo", utilizando o passado "com o propósito de abrir o futuro, convidar à ação, fundar a esperança" conforme afirma Frantz Fanon (1979, p. 193). Desse modo, as suas narrativas de fundação são engajadas porque são instrumentos contra a alienação, são uma tomada de posição diante de uma determinada realidade, procurando atingir o leitor para desvendar o mundo a ele (SARTRE, 2006).

\subsection{As estratégias narrativas utilizadas para contar uma outra história}

Para que Yaka fosse uma narrativa de fundação engajada, conforme o sentido de engajamento estabelecido por Jean-Paul Sartre (2006), sem que houvesse qualquer prejuízo 
do seu valor literário, Pepetela lançou mão de estratégias narrativas semelhantes às utilizadas por Erico Verissimo na elaboração de $O$ tempo e o vento, como a saga familiar, o contraponto, a polifonia e a metaficção, recursos narrativos que permitiram ao escritor angolano conciliar, dentro do seu projeto literário, o elemento ético e o estético, alcançando, dessa forma, o equilíbrio entre literatura de intervenção social e alta elaboração estética. A utilização desses recursos possibilitaram a Pepetela contar a história do colonialismo português em Angola pelo ponto de vista do povo angolano, contrastando-a com a história oficial; fazer uma análise da sociedade colonial angolana; dar voz aos excluídos e silenciados pela história e mostrar diferentes pontos de vista sobre um mesmo assunto.

\subsubsection{A saga familiar}

Yaka constitui-se como uma saga familiar pelo fato de ter o seu principal núcleo narrativo centralizado na história dos Semedo, uma família de colonos portugueses que veio para Angola no final do século XIX, ao mesmo tempo em que a história desse clã está atrelada ao desenvolvimento histórico de uma região de Angola e também da nação angolana.

A obra narra a história da família de Alexandre Semedo, filho do português Óscar Semedo e de dona Esmeralda, considerada portuguesa de segunda por ter nascida em Angola. Alexandre, também português de segunda, casa-se com Donana, uma portuguesa pobre, que veio para Angola em busca de um casamento que pudesse lhe trazer uma condição social melhor, após ter sido desvirginada por um marinheiro em Portugal. Juntos eles terão cinco filhos: Aquiles, Orestes, Eurídice, Helena e Sócrates. Aquiles, Orestes e Eurídice casam-se respectivamente com Glória, Matilde e Bartolomeu Espinha, dando continuidade à descendência da família Semedo, enquanto que Helena morre na infância e Sócrates vai para 
Portugal estudar direito e praticamente desparece da narrativa, só tendo o seu nome citado algumas vezes. Alexandre Semedo também constrói uma descendência fora do casamento, através do seu envolvimento com a mulata Joana, que lhe dá a filha Ofélia. Na página 263 do romance, através da reflexão de Alexandre Semedo, temos a menção de quase todos os membros da família:

Onde está a tradição da família? O pai dele, Óscar Semedo, rugiria de raiva ao saber que bisnetos tinha. Todos uns apolíticos. Já os netos também, talvez só o Sócrates, lá em Portugal, tivesse algumas ideias assentes. Tinha obrigação disso, era advogado. Nunca mais se encontraram. Todos os outros tinham traído o gosto de Óscar Semedo pela política. Era o futebol, as mulheres, os negócios ou a administração. Nenhum era capaz de dizer uma frase interessante, que chatice! Nem mesmo o Heitor, esse ia só para filosofias. A conversa parara de repente e o patriarca olhou os netos sentados à volta dele. Ali estavam os três filhos de Aquiles: Xandinho, Irene e Dionísio. O Sócrates, filho de Orestes, e a irmã, Chucha, lá na janela. Excepto Chucha, todos tinham mais de vinte anos, uma escadinha perfeita. E finalmente, os filhos de Eurídice: Heitor, Jaime e Olívia. Eram ligeiramente mais novos, Heitor tinha vinte e Jaime quatro anos menos; Olívia era a caçúla, só com nove anos. Faltavam os filhos do Sócrates, lá em Portugal. E a Ofélia, sua filha mulata, feita fora do casamento, que vivia no Huambo e um dia viera conhecê-lo, já depois da morte de Donana. Ofélia tinha um filho, Chico, que veio com a mãe. Agora deve ter também vinte anos. Alexandre Semedo tinha um único bisneto, o pequeno Joel, que dormia lá em cima à espera que os pais o levassem para casa. (PEPETELA, 1998, p. 263)

Após essa reflexão feita por Alexandre Semedo em 1961, a sua família é aumentada através do nascimento de mais quatro bisnetos: Eusébio e Sandra, filhos de Xandinho e Alice; e Demóstenes e Aristóteles, filhos de Chico e Sónia.

A utilização dessa estratégia narrativa, a saga familiar, permite a Pepetela entrelaçar a história da família fictícia à história do desenvolvimento da cidade de Benguela e de Angola, de modo a realizar uma análise da sociedade colonial, ao mesmo tempo em que faz uma releitura da história do país, dando voz a tudo aquilo que foi silenciado e obscurecido pela historiografia oficial portuguesa.

Para tanto, Pepetela se apropriou de matéria de extração histórica tanto angolana quanto portuguesa e mundial. Da matéria de extração histórica angolana presente em Yaka 
podemos citar as diversas revoltas dos nativos (Revolta do Bailundo, Guerra preta do Amboim e Revolta dos Seles), as quais o escritor foi buscar na obra do historiador René Pelisier, a história do povo jaga citada na nota prévia, o movimento de ocupação das terras do interior de Angola feito pelos portugueses a partir do Conferência de Berlim (1884-1885), a construção da ferrovia Lobito-Huambo, a guerra de libertação nacional, os acontecimentos às vésperas da independência e a guerra contra os sul-africanos. Quanto à matéria de extração histórica portuguesa, há referências a vários acontecimentos históricos, como o Ultimato Inglês (1890), a crise da monarquia, a proclamação da república, a ascensão de António Salazar ao poder e a Revolução dos Cravos. Em relação à história mundial, há referências às duas grandes guerras mundiais.

Pelo fato de traçar um grande painel histórico, de 1890 a 1975, e de se utilizar de uma família totalmente fictícia para a análise dos acontecimentos históricos abordados, mostrando como essas personagens foram afetadas e como reagiram a determinados acontecimentos históricos, enquanto que as personagens históricas como Silva Porto, Mutuya-Kevela, Ndunduma e Antonio Salazar apenas são mencionadas no romance, compondo o pano de fundo da narrativa, Yaka possui em grande parte de sua extensão uma forma de representação literária característica do romance histórico tradicional, conforme a teorização feita por Georg Lukács (1966), recuperando a singularidade histórica de uma época atravessada por diversas crises históricas provocadas por fatores de ordem econômica (crise da borracha e construção da ferrovia Lobito-Huambo, entre outros) e pelos constantes conflitos entre colonos portugueses e nativos angolanos.

Sob esse aspecto, em sua análise da sociedade colonial angolana, Pepetela representa literariamente como os colonos que viveram naquela sociedade foram afetados por determinados acontecimentos históricos do período (as revoltas, a crise da borracha, o 
Ultimato Inglês) e como reagiram a eles, mostrando como eles pensavam e agiam, pois conforme nos aponta Regina Zilberman:

Lukács concebe o romance histórico como um gênero que não apenas situa o leitor num tempo passado, mas ajuda-o a entender os acontecimentos. Por isso, ele valoriza o modo como se dá a representação do período histórico, que deve corresponder a uma fase de crise e transformação. Contudo, a ênfase do romancista não recai sobre o movimento histórico, e sim sobre seus efeitos sobre as figuras humanas, especialmente quando essas se organizam em núcleos domésticos. (ZILBERMAN, 2003, p. 120)

Nesse sentido, é significativo o trecho em que Óscar Semedo, republicano convicto, toma conhecimento do Ultimato Inglês, pelo qual a Inglaterra impôs à monarquia portuguesa a desocupação de alguns territórios localizados no interior da África, mais precisamente entre Angola e Moçambique:

Quando chegou, o pai de Alexandre soube do Ultimato Inglês. Já tinha passado meses atrás, mas os colonos ainda estavam em efervescência. Óscar Semedo, cada vez que falava disso, espumava de raiva:

- Tiraram-nos o que era nosso. Todo o território do Atlântico ao Índico, o território cor-de-rosa, era nosso por direito natural. De descoberta. Mas os ingleses queriam o meio. E disseram: ou nos dão isso, ou é guerra. E esse rei incapaz e covarde dobrou-se. Os reis de Portugal sempre se dobraram aos ingleses. Por essas e por outras me perseguiram sempre. (PEPETELA, 1998, p. 26)

Dessa forma, ao mostrar como a notícia do Ultimato Inglês foi recebida por Óscar Semedo e como reagiu a ela, Pepetela realiza a intersecção entre os acontecimentos históricos e as existências individuais agrupadas em sociedade (JAMESON, 2007), que é uma das principais características do romance histórico tradicional, pois conforme aponta a professora Marilene Weinhardt, na teoria lukcasiana,

ao romance histórico não interessa repetir o relato dos grandes acontecimentos, mas ressuscitar poeticamente os seres humanos que viveram essa experiência. Ele deve fazer com que o leitor aprenda as razões sociais e humanas que fizeram com que os homens daquele tempo e daquele espaço pensassem, sentissem e agissem da forma como o fizeram. (WEINHARDT, 1995, p. 53) 
Desse modo, a narrativa mostra o pensamento do colono português em relação às terras africanas, como sendo propriedade portuguesa por direito natural de descoberta, sem levar em conta, em nenhum momento, que essas terras já eram habitadas e possuíam donos. O pensamento de Óscar Semedo nos lembra as "estruturas de atitudes e referências" identificadas por Edward Said (1995, p. 89) em textos literários, históricos e etnográficos ingleses, franceses e americanos, em que "havia praticamente uma unanimidade de que as raças submetidas devem ser governadas, (...) que apenas uma raça merece e tem conquistado sistematicamente o direito de ser considerada a raça cuja principal missão é se expandir além de seu próprio domínio". Nesse caso específico, tanto ingleses quanto portugueses pensavam da mesma maneira, que eram detentores legítimos do direito de dispor de territórios para a sua expansão, subjugando os verdadeiros donos dessas terras, pois, segundo Said (Ibid., p. 118), a posse geográfica efetiva da terra está no cerne do empreendimento colonial: "pensar em lugares distantes, colonizá-los, povoá-los ou despovoá-los: tudo isso ocorre na terra, em torno da terra ou por causa da terra."

O Ultimato Inglês acontece em 1890, no mesmo ano em que nasce Alexandre Semedo, o protagonista do romance, de modo que essa data e esses dois acontecimentos relacionados a ela podem ser considerados como o "momento axial" da narrativa, o acontecimento fundador, "o marco zero para a contagem do tempo cronológico" (RICOUER, 2010, p. 181), de que toda ficção de caráter histórico deve conter. Abaixo transcrevemos o trecho em que é narrado o nascimento do protagonista, realizado em primeira pessoa pela voz narrativa da própria personagem.

Nasci em 1890, embaixo duma árvore. A minha mãe foi assistida pela velha Ntumba, escrava ganguela. A escrava, talvez por velhice, deixou-me cair no pó. Segundos apenas. Os suficientes para no meu corpo ficar misturado o pó da terra e os líquidos que trazia comigo ao sair da mãe. O pai berrou que ia matar a velha. A mãe disse que foi sem querer. A velha só chorava, lavando-me. Depois o pai acalmou. (PEPETELA, 1998, p. 18) 
A narração do nascimento de Alexandre Semedo também é feita pela voz narrativa da estátua yaka, conforme veremos na parte desse capítulo que trata da polifonia. A respeito do momento axial, como elemento primordial da narrativa de caráter histórico e, principalmente, de fundação, a professora Inocência Mata (2001, p. 182) identificou Alexandre Semedo, Lueji, do romance homônimo, e Baltazar Van Dum, de A gloriosa família, como personagens primordiais do autor, aquelas que estão na origem da Angola moderna (o primeiro Semedo, a primeira rainha e o primeiro Van Dum), que configuram a busca da identidade e desvelam a recuperação de um mito (de fundação) que sacraliza um território.

Ainda sobre o nascimento de Alexandre Semedo, a professora Maria Aparecida Santilli situou-o juntamente com o Ultimato Inglês como o nó episódico inicial do romance, conforme podemos verificar no trecho abaixo.

... a data de 1890, ano de nascimento de Alexandre, figura central do romance que é a primeira geração angolana da família portuguesa dos Semedos, lance, portanto, de origem da estória de vida que a ficção engendrará, arca a implantação do nó episódico inicial, no período de decorrências históricas do "Ultimatum" inglês, na Colónia, a determinar a eminência e urgência dos esforços de ocupação cujos resultados aparecem, tanto nas guerras do Bié, como em outros, por desdobramentos da resistência dos reinos Ngambu e Humbi, até o marco-fecho de 1904. (SANTILLI, 2002, p. 128)

Também é de 1890 a primeira descrição feita da centenária cidade de Benguela, o espaço onde é ambientado o romance e que vai ter a função de um microcosmo de Angola na estrutura da narrativa.

Benguela dos quintalões. Quintalões onde escravos dos Guanguelas, do Bié, da Lunda, dos Lozi e de mais longe ainda, da costa oriental de África, vinham parar. Engordavam aí para resistir à viagem de barco até S. Tomé, Antilhas ou Brasil. Quintalões de muro alto que escondiam cubatas e mangueiras, vigiados por vimbali atentos, dedilhando kissanges.

(...)

Em 1890 a cidade devia ser o conjunto de quintalões entre o mar e o princípio do bairro da Peça, com grandes vazios no meio. Para a Peça fomos viver. (PEPETELA, 1998, p. 25-26) 
Estabelecidos o espaço e o tempo romanescos, os narradores de Yaka em terceira e em primeira pessoa (quando Alexandre Semedo assume a voz narrativa) ${ }^{19}$ vão mostrar o processo da colonização portuguesa em Angola conforme a visão do colono português, através dos membros da família Semedo, e assim o autor ressuscita literariamente as pessoas que viveram aquela experiência, revelando ao leitor o que sentiam, o modo como pensavam e como agiam, conforme a teoria lukacsiana (LUKÁCS, 1966) sobre os efeitos do movimento histórico sobre as criaturas humanas. Nesse sentido, vejamos como Alexandre Semedo via as constantes bebedeiras do pai, compreendendo-as e justificando-as pelo ambiente iletrado, monótono e ao mesmo tempo hostil em que viviam na Benguela colonial, conforme o diálogo imaginário entre Alexandre e a estátua yaka:

Era cena cada vez mais frequente. Como não haveria de beber, Yaka? A lojeca todo o dia, a aturar negros beberrões que o único português que sabiam era para encomendar vinho. A casa, onde a mulher não o acompanhava nos sonhos. Os amigos da taberna, onde era preciso cuidado a discutir, pois ameaçavam-no com Capangombe. Os livros lidos e relidos. Acho que nunca foi dado a mulheres, não ouvi uma só estória sobre ele. Se ainda fosse católico, ao menos teria Deus. Sim, compreendo-o bem. Benguela era uma vilória sem nada. A partir das oito da noite, as pessoas fechavam-se em casa com medo dos mundombes. Volta e meia havia uma notícia aterradora: que iam atacar o Dombe, que tinha havido tiros na Catumbela, que escravos se tinham revoltado, etc. E todos os meses havia qualquer levantamento dos arredores. Como não havia de beber? Que mais tinha para esquecer? Responda então, raio de estátua! (PEPETELA, 1998, p. 34)

Desse modo, são revelados o preconceito que os colonos nutriam pelo nativo e o medo constante que eles tinham das revoltas levantadas pelos povos que viviam nas regiões próximas a Benguela. Em relação ao preconceito, é necessário lembrar com Albert Memmi (1967) que a justificativa feita pelo colonizador para legitimar o domínio e a expoliação dos

\footnotetext{
${ }^{19} \mathrm{O}$ romance possui sete narradores: um em terceira pessoa e seis em primeira pessoa: Alexandre Semedo, a estátua yaka, o soldado do Cuamato, Chucha, Dionísio e Jaime. Os três últimos narram apenas para contar cada um a sua versão sobre um triângulo amoroso entre eles e por essa razão fogem ao nosso interesse de análise. Discorremos mais sobre as vozes narrativas de Alexandre Semedo e da estátua yaka na abordagem da polifonia e da metaficção.
} 
colonizados e suas terras era de que eles eram seres inferiores por essência: preguiçosos, incapazes, indolentes, ingratos, desleais e desonestos; e com Frantz Fanon (1979) de que para as nações colonialistas em África todo o vasto continente africano era habitado por selvagens, cheios de supertições e fanatismo, e por essa razão, eles estavam fadados ao desprezo e à maldição de Deus.

Assim, dentro do romance, a relação entre nativos e colonos vai ser permeada pelo preconceito, o medo, a exploração econômica e a violência física, de forma que o fio condutor da narrativa será as revoltas que vão ocorrendo a partir de 1890 até culminar no movimento revolucionário de 1961. Nesse sentido, vejamos um trecho em que é narrado o início da revolta dos bailundos que instala um verdadeiro pânico na população de Benguela:

E, de repente, estourou a bomba. Os bailundos se tinham revoltado. Começaram a queimar as lojas dos comerciantes no Bailundo, se falava em centenas de brancos mortos. Outros tinham-se refugiado na fortaleza e estavam sitiados. Temiam a rebelião vai passar para o Huambo, a Tchiaka, o Soque, o Bié. Os alarmistas diziam os bailundos vêm a caminho de Benguela. Nunca vi tanto branco comprar tanta arma. Mesmo alguns degredados perigosos, assassinos, agora passavam na rua ostentado Winchester ou Kropotché no ombro. O pai de Alexandre andava com uma Kropotché e uma pistola. A Winchester ficava em casa com a mãe. Só Acácio andava desarmado. (PEPETELA, 1998, p. 51)

Dessa forma, Pepetela descreve o ambiente colonial na Benguela do começo do século XX, no qual reinava a ideia da existência de um "nós" e de um "eles", cada qual muito bem definido e com seus lugares sociais muito bem demarcados pela ideologia colonial de que nos fala Edward Said (1995, p. 27). Nesse contexto colonial, marcado pelo preconceito e pela exploração física e econômica, emerge a violência do regime colonial e a contraviolência do colonizado, conforme observa Frantz Fanon.

A violência do regime colonial e a contraviolência do colonizado equilibram-se e correspondem-se numa extraordinária homogeneidade recíproca (...) O trabalho do colono é tornar impossíveis até os sonhos de liberdade do colonizado. O trabalho do colonizado consiste em imaginar todas as combinações eventuais para aniquilar o colono. No plano da raciocínio o maniqueísmo do colono produz um maniqueísmo do 
colonizado. A teoria do "indígena mal absoluto" corresponde a teoria do "colono mal absoluto". (FANON, 1979, p. 73)

Quanto à estruturação, o romance é dividido em cinco partes, cada uma delas englobando um período importante da história angolana: "A boca (1890/1904), "Os olhos (1917), "O coração" (1940/41), "O sexo (1961)" e "As pernas (1975). Essas partes compõem a imagem de um corpo em formação, o corpo da nação angolana, como um feto em desenvolvimento. No entanto, para a professora Maria Aparecida Santilli essa estrutura

reproduz o estilhamento, a saga de um corpo (que à leitura irá identificar-se como colectivo), cuja cabeça pode supor-se ambiguamente estar representada no protagonista e/ou que concebeu, para, desse corpo, se conscientizar. Por essa via, os marcos de periodização da odisseia de resistência, no contraponto com os desastres da história de ocupação ampla e efectiva do território angolano, constituem-se lances simbólicos da desorganização de todo corpo físico-social concernente aos povos de Angola. (SANTILLI, 2002, p. 128)

Os períodos históricos focados em cada uma das partes do romance são todos marcados por acontecimentos importantes tanto no aspecto regional/nacional quanto mundial, que vão desde os conflitos: as revoltas dos povos nativos, o Ultimato Inglês, a Revolução Russa, as duas Guerras Mundiais, o movimento revolucionário e a Revolução dos Cravos; até aspectos econômicos como a crise da borracha, a construção da ferrovia Lobito-Huambo e outros elementos associados ao desenvolvimento de Benguela e região. Acompanhando a par e passo todos esses eventos e, principalmente, sendo condicionados por eles, se encontram os integrantes da família Semedo, cujas vidas são transformadas e "remodeladas pelo vagalhão das forças sociais " e históricas (ANDERSON, 2007).

Até as duas primeiras partes (A boca e Os olhos), as principais discussões políticas sobre os acontecimentos históricos eram realizadas no Bar do Lima. Era para lá que os colonos iam beber, saber as novidades e discutir os problemas da colônia. Tanto Alexandre quanto seu pai eram frequentadores do local, e é acompanhando esses dois membros da 
família Semedo que tomamos conhecimento dos pensamentos dos outros colonos sobre as revoltas e a exploração colonial que eles impunham aos nativos.

Acácio tinha sido o primeiro a aparecer depois do almoço na taberna do Lima. Depois foram chegando os outros e até o menino Alexandre Semedo atrás do pai. A conversa foi aquecendo e só podia ser sobre a revolta do Bailundo.

- Devia ter-se conquistado o Huambo e o Bailundo - dizia Sô Agripino de Sousa. - Qual ocupação pacífica, qual bosta! Era com armas, porra. Deixaram lá os sobas a mandar, limitaram-se a por comerciantes e uma guarnição no Bailundo, vejam a merda que deu. Quiseram deixar os reinos independentes, à inglesa. E agora estamos fodidos.

(...)

Mas os outros também estavam alterados. Sem caravanas a chegar, todo o comércio ia à falência.

- Olhem, por uma vez o Governador tinha razão - arriscou o tímido Sô Almeida. - A culpa é dos comerciantes do mato. Roubavam como podiam e agora todos nos lixamos.

- Cale-se lá, homem! - gritou um dos refugiados. - Fala porque nunca andou por lá. Sempre na boa vida da cidade... A culpa é desses oficiais de meiatijela que nomeiam como capitães-mores. Impõem o imposto que querem, para ficar com a maior parte. Provocam revoltas. E quem paga é o comerciante.

- Contaram-me como vocês fazem - disse Óscar Semedo. Fonte insuspeita, um comerciante do Bié. Provocam uma dívida qualquer, geralmente por causa da bebida. Para pagar a dívida, põem os negros a trabalhar para vocês. Geralmente para toda a vida. É mentira ou é verdade? (PEPETELA, 1998, p. 56)

A polifonia de vozes orquestrada pelo narrador em terceira pessoa revela uma situação de exploração do nativo na qual ninguém é inocente: todos os colonos são culpados de uma forma ou outra da exploração dos negros. Até mesmo o barbeiro Acácio, um degradado político que vive honestamente do seu trabalho, indiretamente também faz parte do processo de exploração colonial, conforme ele mesmo assume num trecho da narrativa, por depender do dinheiro dos colonos que exploram a população nativa.

A discussão da exploração colonial realizada no Bar do Lima nos lembra, em parte, as ações que os colonos europeus tinham fundadas no "pressuposto da subordinação e vitimização do nativo" observadas por Edward Said (1995, p. 177): "uma delas é o prazer no uso do poder - poder de observar, governar e tirar proveito de territórios e povos distantes. (...) 
Outra consiste no princípio ideológico para reduzir e depois reconstituir o nativo como indivíduo a ser dirigido e governado."

Alexandre Semedo, na noite de 14 de julho de 1917, em que os colonos de Benguela estavam em suas casas armados e aterrorizados com a perspectiva de um ataque da população nativa que havia se revoltado, resolve acabar com o próprio medo e faz um análise do colonialismo português num desabafo violento que chega a assustar a esposa Donana:

Foi naquela noite de 14 de julho de 1917 que Alexandre Semedo, sitiado em casa pelo medo, escoltado pela grávida Donana, deu um murro na mesa e, como tantos outros, gritou para a posteridade:

- Merda! Não se pode viver sempre com medo. Temos de acabar com eles.

Um silêncio pesado lhe respondeu e nem eu suspirei. Silêncio que vinha das ruas vazias, as casas fechadas e abandonadas. Donana perguntou então a Alexandre, pela primeira vez com respeito:

- Todos, Alexandre?

- Todos! Enquanto houver negros viveremos no medo. Estou-me cagando se se revoltam porque lhes roubam as terras boas para o café. Estou me cagando se se revoltam contra o imposto de ter uma cubata ou contra o imposto do nascimento. Estou-me cagando se a terra antes era deles. Não quero é viver mais no medo. E deixa de olhar assim, Yaka, também me estou cagando para ti e para o que penses de mim.

- Acalma-te, Alexandre. Vais acordar as crianças.

- O meu pai morreu com medo. Eu nasci já com medo. Todos esses vivem só com medo. Não há ano sem revolta. Porra, já chega!

(...)

O problema é que não nos devíamos ter metido no barco, um barco que não dá para todos e onde havia gente antes. Bom. Agora já estamos, não podemos sair. É matar ou morrer. Que sejam os outros a saltar do barco.

- Mas se matam todos, quem vai trabalhar? (PEPETELA, 1998, p. 137-138)

Dessa forma, Alexandre Semedo nomina os principais tipos de exploração a que os nativos estavam sujeitos: pesada carga de impostos e roubo das suas terras, e de certa forma reconhece a exploração absurda que um "nós-colonos" impunham a "eles-africanos", mas prevalece a sua condição de colono, motivada pelo instinto de sobrevivência, do ou nós ou eles. Daí então a sensação de ter entrado num barco furado, sendo que a única saída que se apresentava para os colonos era acabar como a população nativa, mas daí vem a sensata pergunta de Donana: "Mas se matam todos, quem vai trabalhar?", inviabilizando a ideia de 
Alexandre Semedo, pois os colonos precisam não apenas da terra mas também dos nativos para os explorarem.

Neste trecho revela-se a contradição existente dentro do processo colonial, sendo que o desespero e a revolta de Alexandre Semedo diante do medo constante nos lembra a observação feita por Albert Memmi (1967) de que a colonização é uma doença do europeu, havendo, por conta disso, um drama no colonizador, de forma que

... sua cura supõe uma terapêutica difícil e dolorosa, um desenraizamento e uma reforma de suas condições atuais de existência. (...)

A colonização só podia desfigurar o colonizador. Colocava-o diante de uma alternativa com saídas igualmente desastrosas: entre a injustiça quotidiana aceita em seu proveito ou o sacrifício de si mesmo, necessário e jamais consumado. A situação do colonizador é tal que, aceitando-a, apodrece nela, recusando-a, nega-se a si mesmo. (MEMMI, 1967, p. 123)

Proporcional ao crescimento de membros da família Semedo é a ascensão social e econômica que eles experimentam a partir do momento em que o ainda garoto Alexandre Semedo herda do seu padrinho a pequena loja em que seu pai trabalhava. O processo é lento, mas se torna mais rápido e agressivo a partir da entrada de Bartolomeu Espinha na família, através do casamento com Eurídice. Ele, um lisboeta iletrado e sem escrúpulo que viera para Angola em busca de construir um império, e para isso estava disposto a usar todos os métodos disponíveis, inclusive os ilícitos, teve o consentimento de Alexandre para casar com filha justamente por possuir a aptidão para os negócios que faltava ao patriarca e aos outros membros da família, conforme podemos verificar no trecho abaixo em que Alexandre conversa com a esposa Donana sobre a decisão tomada.

-Tiveste uma decisão muito acertada - disse Donana. - E eles vão aceitar, mais cedo ou mais tarde. (...)

- Decisão acertada? Sem dúvida. A família Semedo não nasceu para os negócios. O pai era um político falhado. Eu nunca dei nada na loja. O Aquiles é o que se vê. Só quer pancadarias, almoçaradas, futebol e caça. No trabalho dele até é capaz de ser eficiente, capataz da Câmara é para dar chapadas e pontapés, pôr os negros a trabalhar. Mas sem futuro. O Orestes, coitado, pacífico, só serve mesmo para contar as notas no Banco de Angola. 
Nunca há-de passar disso. O Sócrates talvez desse, mas não me parece que volte. Sócrates era o intelectual da família e Alexandre Semedo mandou-o estudar direito em Lisboa. Se formou, casou e ficou por lá. Nas cartas não mostrava intenção de vir para perto da família. O sonho de Óscar Semedo tinha se cumprido, não em relação ao filho mas ao neto. A família precisava dum fura-vidas, alguém que tomasse conta dos negócios. Tinha encontrado esse alguém, era o fuinha Bartolomeu Espinha. Mesmo se era detestado pelos futuros cunhados, acabariam por aceitar. Além disso, Eurídice estava embeiçada por ele, não compreendia aliás o que podia o fuinha contar, mas na janela ela ria muito. Decisão acertada, sim. (PEPETELA, 1998, p. 171172)

O primeiro negócio em que Alexandre Semedo e Bartolomeu Espinha se associam, uma fazenda para cultivo de algodão, prospera graças a um golpe que o genro aplica roubando o gado do povo cuvale, usando como justificativa a morte do cunhado Aquiles Semedo, que fora morto num conflito com uma família cuvale, conforme veremos na parte deste capítulo dedicada ao contraponto. Bartolomeu fica ainda mais rico depois que pratica outro crime: o massacre e o roubo das terras do soba Mona, vizinho de sua fazenda. Assim, na parte final do romance, quando a independência está prestes a acontecer, ele e Matilde Semedo (nora de Alexandre, casada com Orestes) são colonos ricos, detentores de poder econômico e social na colônia, enquanto que Alexandre Semedo tem uma situação econômica confortável que permite cuidar do restante da família.

Um pouco antes da entrada de Bartolomeu Espinha na família Semedo, por volta da metade da década de 30, Alexandre já dera um salto econômico e social considerável ao adquirir com suas economias o sapalalo, residência de dois altares feita de madeira e que era na época um dos símbolos do poder colonial português em Angola. A aquisição o promoveu à categoria de comerciante com loja e casa própria.

Comprou o sapalalo cinco anos atrás. Sempre tinha vivido em casa alugada. Nem onde dormia era dele. Tinha guardado umas economias, porque a loja finalmente dava certo lucro. E um dia o Gomes foi à falência e os bens dele foram leiloados. Também esse sapalalo de madeira, de dois pisos e por isso era um sapalalo com cinco quartos e uma imensa sala. Varandas nos dois lados e atrás. À frente, para a rua, a varanda era no piso superior. Coisa linda esse sapalalo em ruínas. Estranhamente, ninguém se interessou pela casa. A crise com a criação do Estado Novo traziam desassossego, ninguém 
arriscava em propriedades urbanas. Alexandre arrematou o sapalalo por preço irrisório. As economias ainda lhe deram para restaurar a casa. $\mathrm{O}$ sapalalo tinha-o promovido à categoria de comerciante com casa própria, loja e residência. (PEPETELA, 1998, p. 173-174)

A partir de "O coração", parte ambientada nos anos 1940/41, o sapalalo passa a ser a moradia oficial dos Semedo e também o espaço de discussão política que antes era ocupado pelo Bar do Lima. Dessa forma, a discussão dos acontecimentos históricos e políticos que antes se realizavam num espaço público, com amigos e conhecidos, passa para o espaço doméstico, sendo realizada entre os membros do clã. Nesse sentido, o sapalalo ocupa um papel estrutural semelhante àquele ocupado pelo sobrado dos Terra-Cambará em $O$ tempo e o vento, de Erico Verissimo. Por causa dessa posição central que o casarão dos Semedo ocupa a partir deste ponto na narrativa, podemos considerá-lo também como o "cronotopo" de Yaka, o centro organizador dos principais acontecimentos temáticos do romance, tendo também, a exemplo do que apontamos na trilogia de Verissimo, uma função similar àquelas exercidas pelos cronotopos do castelo e do salão-sala de visita, onde há o entrelaçamento entre que é particular e privado com o que é histórico, social e público; entre a intriga pessoal e a política, entre a série biográfica e a histórica (BAKHTIN, 1998).

Desse modo, em fevereiro de 1961, a família Semedo, já bem mais numerosa, com filhos, genro, nora e netos, e já elevada socialmente e economicamente, se reúne no sapalalo para discutir os acontecimentos de fevereiro de 1961, que desencadearam o movimento revolucionário angolano.

A família Semedo estava toda reunida no sapalalo, como acontecia sempre que havia acontecimento importante. Este era, sem sombra de dúvida. Tão grave que todos calavam, vergados ainda ao peso das notícias.

- No passado houve muitas dessas coisas - disse Alexandre Semedo. Acabaram sempre da mesma maneira. Atirava-se uns contra os outros. Agora é diferente. Começou na capital, agora está a espalhar-se. É muito mais sério.

(...)

Esta toma as feições da revolta do Seles - continuou Alexandre. - Por causa das terras de café. Mataram alguns roceiros, o distrito estava todo a ferro e fogo. Aqui havia as notícias mais alarmistas. Que os calcinhas tinham planos 
para matar todos os brancos, mesmo em Benguela. Ninguém queria ter cozinheiros em casa, medo dos envenenamentos. Não é o que se diz agora do Norte? Os cozinheiros das roças envenenam a comida, depois trucidam as famílias? Igual. Afinal não houve nada em Benguela. Os bailundos foram ao Seles e deram cabo da rebelião. Era revolta localizada e não transbordou. Agora começou na capital, é diferente. (PEPETELA, 1998, p. 254-255)

A eclosão do processo revolucionário, através da luta armada, tal como aconteceu em Angola a partir de 1961, é vista por Frantz Fanon (1979) como uma indicação de que

o povo está decidido a só depositar confiança nos meios violentos. Ele, de quem sempre se disse que só compreendia a linguagem da força, resolveu exprimir-se pela força. Com efeito, o colono jamais deixou de lhe mostrar o caminho que devia ser o seu se quisesse conquistar emancipação. $\mathrm{O}$ argumento escolhido pelo colonizado foi-lhe indicado pelo colono e, por uma irônica reviravolta das coisas, o colonizado é de quem agora afirma que o colonialista só entende a força. (FANON, 1979, p. 65)

A repressão cruel e violenta ao movimento revolucionário levada a cabo pelas autoridades coloniais portuguesas serviu aos propósitos inescrupulosos de Bartolomeu Espinha, que já há algum tempo estava de olho nas terras da fazenda do soba Mona. Ele se aproveita da situação de paronoia do momento para arquitetar uma farsa que leva ao massacre de toda a família do soba e, por conseguinte, as terras produtivas do nativo vão parar em suas mãos, tornando-o ainda mais rico. O massacre da família nativa, um dos momentos mais marcantes da narrativa que reflete toda a exploração colonial, é narrado pela voz da estátua yaka, que incorpora uma voz coletiva de todos os excluídos pelo poder colonial.

Eu vi, não me contaram, eu vi um sábado sangrento.

Com esses olhos que andaram por tanto lado, sem sair duma mesa de parede, com esses olhos rodeados de branco e vermelho e azul, mas transparentes. Foi assim naquele sábado e o que veio depois.

Aspirante Xandinho e mais o tio dele e o irmão e o primo e outros brancos e ainda o mulato Guilherme, com as armas deles a brilhar a brilhar naquela noite de Lua cheia entre nuvens, a andarem devagar devagar, (...) se aproximaram da casa do soba Mona, onde tudo estava a dormir, ninguém que lhes ouviu chegar, aí cercaram a casa, eram vinte, deu para cercarem também a casa das mulheres, no momento mesmo em que outros grupos estavam entrar nas sanzalas, (....) pega masé é fogo à cubata para iluminar as cenas e Guilherme mulato obedece, labaredas subindo para o ar, se enterraram as armas nas cubatas as munições vão explodir, afastem-se, vermelhos-laranja subindo beijar o azul-escuro do luar, nuvens alaranjadas 
na Lua de ouro-prata, beijo da traição, a cara de Bartolomeu contorcionada pelas chamas, sorriso esgar na cara magra de rato, um império, tudo por um império,... (PEPETELA, 1998, p. 313-314)

O desfecho da reunião no sapalalo referida anteriormente só se daria 14 anos depois, em 1975, numa outra reunião em que:

Os ventos de pânico entravam agora pelas portas e janelas do sapalalo. Alexandre Semedo sentia as vagas de frio percorrerem todos os esforços e se depositarem em Glória, agora sem o filho e netos, se depositarem no Orestes e família, mesmo na Chucha que perdera de repente o ar atrevido. A tempestade, essa, chegou com Bartolomeu, quando tinham acabado de jantar.

- Prenderam-me. Prenderam-me por umas horas.

Tinha o ar de fuinha muito mais vincado, os olhitos a saltitar para todos os lados. Alexandre Semedo não tinha à sua frente Joel, só estavam os pais dele, por isso não escondeu o interesse pela notícia.

- Queriam saber do camião que dei à FNLA. Disse que era só emprestado, eles insistiram que foi dado. Enfim, não devem ter provas cabais. Chatearam-me mais com o carregamento de munições que mandei ir buscar ao Norte. Eles ouviram qualquer coisa. (PEPETELA, 1998, p. 362-363)

$\mathrm{O}$ contexto em que esta reunião acontece é o momento em que as Fapla ${ }^{20}$ impõem derrotas significativas às forças da Unita e FNLA e coloca o MPLA na condição de assumir o controle administrativo da nação que surge oficialmente em 11 de novembro de 1975. Esta é a razão do pânico de Bartolomeu Espinha e de todos os membros da família Semedo, à exceção de Alexandre e Joel, pois se aproxima o momento do acerto de contas dos séculos de exploração colonial portuguesa. Diante da catástrofe iminente, os Semedo, a exemplo de muitos outros portugueses e descendentes, preocupados com suas situações econômicas, políticas e sociais, só veem como saída a fuga para a África do Sul ou Portugal. Os únicos integrantes da família que se dispõem a ficar são o patriarca Alexandre Semedo, que sofre um longo e lento processo de angolanização, o seu neto mulato Chico e o seu bisneto Joel, que se engaja nas Fapla. É fim do império erguido por Bartolomeu Espinha à custa do massacre de nativos e do roubo de suas terras, que remete ao fim do colonialismo português em Angola.

\footnotetext{
${ }^{20}$ Fapla - Forças Armadas Populares de Libertação de Angola, ligadas ao MPLA.
} 
Na noite em que a família Semedo foge para a África do Sul, Joel ouve um tenente português, namorado de sua prima Chucha, contar-lhe sobre o caos reinante no porto do Lobito, onde já não havia espaço para abrigar as levas de colonos que chegavam a todo momento, carregados com seus pertences, tentando embarcar para Portugal. Desconhecendo a gravidade dos crimes cometidos por alguns de seus parentes no período colonial, Joel não compreende o porquê da paranoia deles, assim como dos demais colonos, em querer fugir.

- Então explique-me por que querem bazar todos - disse Joel.

O tenente brincou com o copo de uísque.

Têm medo. De tudo. Sobretudo do passado.

- Os que fizeram crimes, está bem disse Joel - Mas o meu pai de que pode ter medo? Sempre foi um desgraçado. Nem sei como vai viver lá fora, não sabe fazer nada...

- Aí o caso pode ser diferente. Mesmo sem saber fazer nada, como dizes, aqui tinha o emprego. Era superior aos negros, tinha o estatuto de branco. Sabe que vai perder esse estatuto. A partir de agora será igual a eles, não terá privilégios. Tem de mostrar o que sabe fazer. É duro para quem toda vida viveu pensando ter inferiores. De repente já não os tem. É igual a eles...

- Mas lá vai ser inferior a todos!

- A todos os que ele considera seus iguais. Não pode aceitar o risco de ser inferior aos que ele toda a vida considerou inferiores...

É muito complicado tudo isto. (PEPETELA, 1998, p. 288)

O passado de violência contra os nativos é um verdadeiro pesadelo para o colonizador no momento da descolonização, trazendo o medo da revanche do colonizado que viveu a vida inteira sob o jugo do poder colonial. O caráter conflituoso e não pacífico da descolonização, carregado de medo, insegurança e violência, que quase sempre provoca o retorno dos colonos aos países colonizadores é explicado por Frantz Fanon (1979) e Albert Memmi (1967).

Para Fanon (1979), a descolonização é sempre um fenômeno violento, substituindo, sem transição, completa e absolutamente, uma espécie de homens por outra espécie de homens, e é também um programa de desordem absoluta, quando se propõe a mudar a ordem do mundo.

A descolonização, sabemo-lo, é um processo histórico, isto é, não pode ser compreendida, não encontra a sua inteligibilidade, não se torna transparente para si mesma senão na exata medida em que se faz discernível o movimento 
historicizante que lhe dá forma e conteúdo. A descolonização é o encontro de duas forças congenitamente antagônicas que extraem sua originalidade precisamente dessa espécie de substantificação que segrega e alimenta a situação colonial. (FANON, 1979, p.26)

E para Albert Memmi (1967), a descolonização é um processo lento, difícil e doloroso, comparável à convalescença de uma longa e grave enfermidade.

Dessa forma, o que se passa nas páginas finais do romance, com a fragmentação completa da família Semedo e com a tomada do poder e do controle territorial pelo grupo de revolucionários angolanos do MPLA, é um quadro de desordem absoluta que inverte a ordem política da colônia. Nesse novo ciclo da história angolana que se desenha só há lugar para portugueses e descendentes que se tornarem angolanos, ou seja, para aqueles que aceitarem a nova condição social em que estarão no mesmo nível dos angolanos nativos, destituídos dos princípios de superioridade de raça e classe que o regime colonial lhes outorgava.

No entanto, Alexandre Semedo, com a sabedoria de quase um século de vida, observa a Joel, que adotara Ulisses como nome de guerra, que a utópica compreensão entre os homens angolanos pode ser algo que ainda demore a acontecer e é que preciso, antes de tudo, ultrapassar o peso da história. Por isso, aconselha o bisneto a não se iludir.

Não te iludas, Ulisses. Pode não ser para este século.

- Aqui vamos todos entender-nos, avô. Já estamos a lutar juntos, homens de raças diferentes. Será o primeiro caso em África, dizem os camaradas.

- É preciso ultrapassar muita coisa, o peso da História. Essa estátua não fala para todos, ainda é só para raros eleitos como tu. Não te iludas...

- É este ou não o caminho, avô?

- Claro que é. Quando nasci, deixaram-me cair no chão. E comi a terra. É isso, acho que não é feitiço nenhum. E se for... (PEPETELA, 1998, p. 388)

A observação de Alexandre Semedo feita ao neto reflete uma preocupação antiga do autor que remonta ao romance Mayombe, quando na esteira do pensamento de Frantz Fanon (1979, p.167), que afirmou que o nacionalismo que moveu as massas no continente africano contra o colonizador europeu "se desagrega no dia seguinte ao da independência", Pepetela 
alertou que o movimento revolucionário angolano carregava dentro de si o ovo da serpente do poder e por isso havia o risco no pós-independência do novo grupo dirigente se tornar uma nova ditadura sobre o povo, conforme a sua percepção histórica do caráter cíclico da reconstituição das classes dirigentes. Por essa razão, o alerta ao neto nacionalista para conter o entusiasmo e não se iludir com a perspectiva de uma independência total, pois esta poderia demorar ainda muito tempo para ocorrer, e só poderia vir, segundo afirma Fanon (Ibid., p. 207), se se desse um rápido passo "da consciência nacional para a consciência política e social".

A narrativa da saga da família Semedo, que se inicia com o nascimento de Alexandre em 1890, termina com a sua morte em 1975, poucos dias antes da independência de Angola. Ao morrer, ele leva a estátua yaka para o quintal do sapalalo, cujas paredes de madeira já estavam há muito tempo corroídas pelo salalé e ameaçavam desabar a cada obus que passava sobre o casarão, e faz um balanço da sua vida, morrendo em paz com a sua consciência e com a terra angolana:

É o fim, pensou ele, já sem forças para o dizer em voz alta. Devo fazer o balanço da minha vida. (...) Só tenho que fazer a das perdas. Uma família a que dei origem, hoje espalhada pelo mundo. Só Joel e Chico sobraram. E Joel talvez agora já esteja morto, sem sepultura. É importante estar sem sepultura? Gostaria de levar a enterrar esse menino que descobri no fim da vida. E fui egoísta e ia dizer-lho, quando me alegrei que fosse lutar. Ia fazer o que nunca fui capaz de fazer, ele ia redimir-me. É sempre assim, descobre-se demasiado tarde. Não deixará traço no mundo. Nem o sapalalo. Não foi ele que o construiu, mas deixei-o apodrecer, já saí pó por todos os lados, basta uma explosão aqui perto para ele desabar. Nada, não deixa nada atrás dele. A sociedade será outra nesta terra, nem vestígios registará na História. A História guarda os feitos de heróis, na medida que interessam às forças vitoriosas da época. Não são os seus vestígios que a nova sociedade vai querer na História. Um colono a mais. Para esquecer. A culpa foi minha? Tinha sido apenas o mexilhão da história, uma bimba que se afogou porque duas vagas chocaram exactamente sobre ela.

(...)

A terra que a boca de Alexandre Semedo morde lhe sabe bem. É o cheiro do barro molhado pelo orvalho de madrugada e o som longínquo de badalos de vacas na vastidão do Mundo. Leva esse sabor e cheiro de terra molhada para cima da pitangueira, onde fica a balouçar, para sempre. (PEPETELA, 1998, p. 393-395) 
Dessa forma, no final do romance há uma simbiose entre Alexandre Semedo e a estátua yaka. Pela primeira vez na narrativa o patriarca entende a sua linguagem e vê pelos olhos dela as imagens que só ela poderia ver e narrar. O destino da família que desde o início esteve ligado ao destino de Angola também termina totalmente imbricado com o da excolônia que se torna nação. A morte de Alexandre coincide com a morte do colonialismo português em Angola e a fragmentação da família Semedo é equivalente à desestruturação social que ocorre às vésperas da independência, com a fuga em massa dos colonos. Mas ao mesmo tempo, o fim do regime e da sociedade colonial remete ao início de uma nova sociedade formada "por todos aqueles que compartilham dos mesmos ideais, não importando raça ou nacionalidade" (MARTINS, 2002, p. 297) e a cena da morte de Alexandre Semedo é também a imagem da angolanização do colono: ao morrer, ele morde a terra angolana novamente, como fizera ao nascer, mas desta vez o gosto da terra lhe sabe bem e ele leva esse sabor para os galhos da pitangueira, local onde vai habitar depois de morto, como manda as tradições dos povos angolanos, e assim, conforme observa Via Rossi Martin (2002, p. 296), ocorre a reconciliação definitiva de Alexandre Semedo com o verdadeiro espaço de sua nacionalidade, incorporando os valores e os interesses do povo angolano.

\subsubsection{A técnica narrativa do contraponto}

A técnica narrativa do contraponto é utilizada por Pepetela em Yaka para contar a história sob o ponto de vista de uma família que foi massacrada pela polícia colonial portuguesa, a família cuvale de Vilonda, formada por ele, suas duas mulheres, seus filhos, mais uma irmã e um sobrinho. Segundo afirma Pepetela a Michel Laban (1991), a história 
dos cuvale, uma população pastora que habita a região sul ocidental de Angola, foi a parte do romance mais prazerosa em ser escrita e por isso a história deles é tratada com mais carinho.

A introdução da história dessa família funciona na estrutura da narrativa como uma antissaga em contraste com a família Semedo, representando todos os nativos que sofreram a violência do processo colonial em Angola, tendo papel similar àquele ocupado pelos Carés em O tempo e o vento, de Erico Verissimo. Nesse aspecto também podemos ver a presença dessa família que ocupa um papel marginal, ou seja, está fora do centro da narrativa ocupado pela família Semedo, como um grupo ex-cêntrico, no sentido definido por Linda Hutcheon (1991, p.89) como "grupos anteriormente silenciosos definidos por diferenças de raça, sexo, preferências sexuais, identidade étnica, status pátrio e classe", que a partir dos anos 60 passam a ser registrados na história. E por outro lado a utilização desse recurso narrativo, juntamente com a polifonia, possibilita ao autor contar outras versões da história, dando voz a tudo o que foi silenciado e excluído da historiografia portuguesa. Nesse sentido, o uso dessa estratégia narrativa faz com que o romance contenha algumas das características identificadas por Fernando Ainsa (1991) no novo romance histórico latino-americano, que são a releitura crítica da história, com o propósito de impugnar a legitimação instaurada pela história oficial, e a multiplicidade de perspectivas possíveis que faz com que não haja uma só verdade do fato histórico.

Também podemos relacionar essas características de Yaka à metaficção historiográfica, conforme a definição de Linda Hutcheon (1995). Embora haja sérias dúvidas acerca da pós-modernidade da obra de Pepetela, a professora Inocência Mata (2006, p. 49) considera não apenas Yaka, mas também os romances Mayombe, Lueji, o nascimento dum império, A geração da utopia, Parábola do cágado velho e A gloriosa família como "metaficções historiográficas", vistas por ela como "romances que se apropriam de personagens e acontecimentos históricos, não para simplesmente celebrar o passado mas para 
o utilizar como veículo de uma reflexão sobre a própria condição presente do país e sua projecção futura". Sob esse aspecto, Anselmo Peres Alós (2007, p. 3) observa que ainda que seja difícil ver a obra de Pepetela filiada à estética pós-moderna, pelo fato de ela abordar um universo onde o colonialismo, e não modernidade, forneceu a matéria histórico-social para a produção cultural e literária, há em seus escritos "aquilo que de mais pós-moderno há na produção literária", especialmente as duas principais características da metaficção historiográfica: "a ficcionalização e reescritura do discurso histórico oficial, acompanhadas de uma reflexão sobre o ato da escritura do mesmo, e da própria reescritura promovida pelo exercício literário pós-moderno."

Retomando a história da família cuvale, ela ocupa os capítulos 2, 5, 8 e 11 da parte "O coração" e é narrada em terceira pessoa por um narrador que não procura se distanciar ou fingir imparcialidade diante dos fatos narrados, e sim dá amostras de simpatia e solidariedade em relação à família de nativos, através de uma narração em que ele "toma para si o discurso do oprimido", definição de que nos apropriamos de uma observação feita por Eduardo de Assis Duarte (1998) sobre Jubiabá, de Jorge Amado, conforme podemos verificar no trecho abaixo que dá início à história da família de Vilonda, em que o mundo dos cuvale é descrito como um ambiente em total harmonia:

Vilonda, sentado no rochedo azul do seu território, olhou o rio Cuporolo. Espera a volta das duas mulheres que tinham ido à lavra. Terra boa, a do Cuparolo. Daqui se via as bandeiras do milho pintar de branco o verde da lavra. E para os bois então? O rio tinha água todo o ano, o capim estava sempre verde e tenro, os bois engordavam e luziam. Virou a cabeça para a esquerda e viu a manada. $\mathrm{O}$ filho mais novo e o sobrinho trazem os bois para o curral. A manada sobe o morro que nasce ao lado do rio, ondulando entre os penhascos, reconheceu no meio dela a namulilo ${ }^{21}$, a vaca mais sagrada de todas, o boi mocho, o dos cornos retorcidos, o malhado, a vaca cega, os vitelos. Ao todo, oitenta animais. Subiam sem pressa, de barrigas atulhadas, as vacas cheias de leite agitando os chocalhos. Um ou outro mugido eram música no seu ouvido. Encheu o peito de ar. Tudo estava ali. O cheiro, o som, a luz. Terra boa essa do Cuporolo.

(...)

\footnotetext{
${ }^{21}$ Vaca sagrada dos cuvale.
} 
Lá vêm as duas mulheres e as filhas da lavra. Vêm a conversar contentes. A filha mais velha dá uma gargalhada que repercute de rochedo em rochedo até chegar a ele. Um grande paz inundou Vilonda. (PEPETELA, 1998, p. 176)

Essa harmonia, típica de um ambiente ainda não contaminado pelo colonialismo, começa a ser quebrada primeiramente pela passagem de um avião, o grande pássaro que sobrevoa diariamente o território cuvale e que desinquieta a namulilo, comportamento que é interpretado por Vilonda como presságio de um acontecimento ruim, pois a vaca sagrada nunca se engana e isso traz a Vilonda uma angústia no peito e acaba com a sua paz do fim de tarde; e depois pelas notícias trazidas pelo filho mais velho, que estava percorrendo as aldeias cuvale para cumprir um rito de iniciação antes de se casar. O relato feito por Tyenda é aterrorizador, pois a guerra estava por todos os lados da terra cuvale, confirmando o mau presságio da namulilo. Conta ele ao pai:

No Caitou disseram não avances mais que havia guerra na Bibala, no Pocolo, em todas as partes. Guerra? Já não as habituais razias dos colonos e polícias que vinham requisitar o gado aos cuvale. Agora é guerra mesmo. Tudo começou, porque três cuvales foram à loja dum comerciante e o comerciante lhes deu de beber, de beber, até eles adormecerem. Quando acordaram, viram o gado deles tinha sumido. Bateram no comerciante, este disse onde estava o gado. Na cerca dele, já com as marcas de ferro vivo. Eles foram lá recuperar o gado. Os guardas do branco não queriam deixar, eles perderam a cabeça. Mataram os dois guardas com os onjaviti ${ }^{22}$. Levaram o gado deles e como castigo levaram o resto que tinha lá. Aí começou a guerra. Os polícias vieram, começaram a atacar as ongandas. A matar toda a gente, homens, mulheres, crianças. E levavam o gado todo. A guerra já estava na Bibala e em Capangombe, no Bentiaba também, os cuvale de Moçamedes dispersaram pelo deserto, os bois perdidos a morrer de sede na areia, ninguém que os levava para as cacimbas. As gentes de Caitou iam retirar para as Mundas do Hambo, único sítio onde se podiam proteger quando havia seca ou guerra. Tyenda retirou com elas. Em Camucuio, as ongandas já estavam vazias e algumas mesmo ardiam. Tyenda se misturou às gentes e ao gado que em longas filas avançavam para Chiquite e as Mundas. No caminho foram atacados por um pássaro grande que vomitava fogo. Muitos homens e bois morreram. O pássaro baixava, ficava muito grande e roncando muito e se via as faíscas saltar dele e as pessoas e os bois a cair, mortos. (PEPETELA, 1998, p. 200-201)

\footnotetext{
${ }^{22}$ Onjaviti - machado.
} 
O relato feito por Tyenda ao pai mostra o conflito visto pelo olhar do nativo, ou seja, pela ótica dos vencidos, conforme a concepção benjaminiana (BENJAMIN, 1985). Sem ocultar os erros cometidos pelos cuvale que mataram os dois guardas e roubaram o resto do gado do comerciante, em represália ao roubo de que tinham sido vítimas, Tyenda conta a monstruosa ação bélica montada pelos colonos, que tomavam um fato isolado como pretexto para massacrar os nativos, não se importando em matar mulheres, crianças e velhos, e roubar todo o gado que encontravam. Ao encontro da ação dos colonos portugueses, lembramos a observação feita por Frantz Fanon (1979) de que o aparecimento do colono significou a morte da sociedade autóctone.

Pouco tempo depois do relato de Tyenda, a família de Vilonda, conhecida por ser pacífica e nunca ter criado problemas, conforme a descrição de um comerciante do Dombe Grande, sofreria o mesmo tipo de violência, quando Tyenda é assassinato pelo truculento Aquiles Semedo e seu grupo de amigos que tinham ido caçar nos arredores da onganda ${ }^{23}$ cuvale. No conflito Aquiles também morre, alvejado no peito pela azagaia de Vilonda, morte que serve de pretexto para Bartolomeu Espinha arquitetar junto ao exército o massacre da família de Vilonda para que ele pudesse roubar o gado cuvale. O capital conseguido através desse roubo teria importância fundamental na ascensão econômica do colono português que buscava construir o seu império particular em Angola. Na narração do massacre, altera-se a voz narrativa e quem narra é a voz solidária da estátua yaka, que tudo vê e tudo acompanha no decorrer da narrativa:

Os orgulhosos cuvale aguentaram o primeiro ataque do pássaro estranho que deitou fogo e bala na onganda. os meninos fugiram para o seio das mães, não choraram. Depois vieram os soldados, o medo nos olhos. Viram Vilonda de pé, fugiram. O estranho pássaro deu a volta, veio de novo. Baixinho, baixinho. Tac-tac-tac saía dele. E uma das balas que rebentaram mesmo no meio da onganda e os tectos das cubatas voaram e Ngonga caiu de vez e o filho dele também. Só Vilonda que ficou de pé e os soldados não avançaram. Mas os do outro lado já não tinham Ngonga e o filho a lhes travar. Quando

\footnotetext{
${ }^{23}$ Onganda - habitação cuvale.
} 
Vilonda virou para o lado, os soldados de cáqui estavam entrar na onganda. Os tiros eram demais. A primeira bala entrou no braço de Vilonda e o arco caiu. A segunda entrou na barriga, a terceira na cabeça. O corpo caiu no pó fininho entre as pedras e os soldados passavam e disparavam nele, com a raiva do medo. Mas nenhuma entrou no coração dele. As mulheres corriam entre os restos de cubatas e os soldados disparavam. (PEPETELA, 1998, p. 246-247)

Dessa forma, a repressão do sistema colonial é violenta. Roland Corbisier, no prefácio escrito ao Retrato do colonizado precedido pelo retrato do colonizador (1967), de Albert Memmi, comenta a violência da reação dos governos coloniais às manifestações de inconformismo e rebeldia dos povos colonizados, que lembra muito a reação colonial portuguesa não só no episódio dos cuvale, mas também em todos os outros referentes às revoltas que abordamos anteriormente.

O empreendimento colonial, desafiado pelos povos em revolta, se revela em sua verdadeira fisionomia. A violência que permanecia latente, implícita na opressão, explode, e o colonialismo, com a assistência e o beneplácito da metrópole, passa a reprimir sistemática e brutalmente todas as manifestações de inconformismo e rebeldia. (CORBISIER, 1967, p. 14-15)

Desse modo, através da técnica do contraponto, o escritor mostra o outro lado da moeda, ou seja, a outra história. Juntamente com a história de prosperidade dos colonos portugueses é mostrada também as histórias de violência e espoliação que os angolanos nativos sofreram durante o processo colonial, por meio de um processo engendrado pelo autor visando "recuperar suas histórias reprimidas" (BHABHA, 2010, p. 29). O trabalho escravo, o roubo das terras, o estupro das mulheres, os massacres em massa de nativos, tudo isso é mostrado como um dos fatores responsáveis pela prosperidade dos colonos a que nos referimos anteriormente. Por isso, o romance tem um teor todo anticolonial. Ele visa, sobretudo, contar a verdadeira história do colonialismo português em Angola e sua derrocada que se dá na parte final do romance. Nesse sentido, o romance põe a descoberto toda a hipocrisia da propaganda colonial, ao retratar a crueldade com que esse empreendimento foi 
praticado, e assim Pepetela toma a sua posição através da literatura, utilizando-a como crítica da alienação, denunciando através dela todas as injustiças de onde quer que venham e desvendando o mundo e oferecendo-o ao leitor como um convite à reflexão, na esteira daquilo que Jean-Paul Sartre (2006) pensava sobre o papel do romancista.

\subsubsection{A polifonia}

Yaka é um romance essencialmente polifônico. Nele, a polifonia acontece de duas formas: através dos diálogos travados entre as personagens, principalmente nas conversas no Bar do Lima e nas reuniões da família Semedo realizadas no sapalalo, nas quais emergem-se ideias divergentes a todo momento, e pela existência de diversos narradores, cujos pontos de vista são diferentes. A predominância desse recurso narrativo deve-se a um aspecto importante do projeto literário de Pepetela: "dar voz aos que não tiveram voz na História", conforme bem observou Fabrice Aimé Fernand Schurmans (2012, p. 352).

Dessa forma, o caráter polifônico de Yaka produz um descentramento da narrativa, destruindo a simulação de distanciamento e imparcialidade do romance histórico tradicional e produzindo assim várias versões de um mesmo fato, seja ficcional, como o nascimento de Alexandre Semedo no início do romance, ou histórico, como a guerra do Amboim, reforçando, dessa forma, a presença na narrativa das três características do novo romance histórico que apontamos na parte sobre o contraponto (fazer uma releitura crítica da história através da impugnação da história oficial, dar voz a tudo que foi silenciado e apresentar mais de uma versão do fato histórico) e reforçando também a presença das características da metaficção historiográfica que Inocência Mata (2006) e Anselmo Alós (2007) veem no romance. 
No primeiro caso, a polifonia constituída por meio do diálogo, a utilização dessa estratégia narrativa serve para o autor inserir vozes divergentes entre os atores que participam diretamente do processo colonial, como, por exemplo, a do barbeiro Acácio, anarquista e republicano que veio para Angola como degredado político, e que critica abertamente a atitude exploratória de seus compatriotas, mesmo reconhecendo que indiretamente ele também participa da exploração colonial por depender financeiramente do serviço prestado aos colonos. No trecho abaixo, reproduzimos parte de um diálogo em que Óscar Semedo chama a atenção de Acácio, acusando-o de estar passando dos limites ao lembrar aos colonos seus passados de crimes cometidos em Portugal.

- Também acho que você está a passar das marcas.

- Acha?

- Sim, Acácio. Que se insurja contra os erros, muito bem. Mas sempre a ofender as pessoas, a lembrar o passado que querem esquecer, isso não.

(...)

- São muito sensíveis - disse Acácio. - Aqui, agora. Quando fizeram lá as patifarias que os levaram ao degredo não eram tão sensíveis. Encolhiam-se à rente dos polícias que lhes batiam. Conheço o género. Vêm para aqui e são respeitáveis. Até se ofendem por se lembrar o passado crapuloso deles. E você quer que os trate como senhores, esses delinquentes?

- Foram delinquentes, mas corrigiram-se. Ou não admite que tenham corrigido?

- Corrigiram uma merda! Só que agora roubam ou assassinam os negros e isso já não é considerado delinquência porque tudo que seja mau para os negros é bom para a Pátria.

- Nem tanto assim.

- Nem tanto assim? Não deu o exemplo há bocado com o truque das dívidas para manter a escravatura camuflada? E agora quer convencer-me que não continuam delinquentes? De que lado está afinal?

- Do lado da justiça - disse Óscar Semedo.

- Qual justiça? A deles é claro.

- A justiça é só uma.

- Devia ler Proudhon ou Kropotine. Há sempre duas justiças: a dos opressores e a dos oprimidos. E você parece que escolheu a dos opressores. (PEPETELA, 1998, p. 58)

Pela voz do barbeiro Acácio são denunciadas várias injustiças históricas cometidas contra as populações nativas e vários crimes praticados tanto pelos colonos quanto pelas autoridades portuguesas, de modo que ele acaba morrendo violentamente por causas das suas 
ideias de justiça e liberdade e pelas denúncias que fazia em público. Por essa razão ele é uma das personagens que possui a simpatia do autor e também de grande parte da população explorada da fictícia Benguela, tanto é que o seu enterro, rejeitado pela igreja, foi celebrado pelo povo das sanzalas como manda as tradições africanas: "Mas o povo das sanzalas deu ao enterro a cor que a Igreja não quis dar. Ao ritmo de ngomas ${ }^{24}$ e carpideiras. E um coral improvisado que cantou em umbundo no momento do caixão entrar na cova" (PEPETELA, 1998, p. 116).

No segundo caso, da polifonia por meio da diversidade de narradores, temos sete narradores em Yaka, um narrador onisciente em terceira pessoa e seis em primeira pessoa: Alexandre Semedo, o soldado do Cuamato, a estátua yaka (que também narra com total onisciência), Chucha, Dionísio e Jaime. Conforme já observamos, os três últimos tomam a voz narrativa para contar cada um a sua versão sobre um caso amoroso entre eles e por esse motivo fogem ao interesse de nossa análise. No entanto, o narrador em terceira pessoa e a narração em primeira pessoa de Alexandre Semedo e da estátua yaka misturam-se no decorrer da narrativa, sendo que, muitas vezes, fica difícil até identificar qual voz narrativa está no comando da narração, pois acontece de elas mudarem dentro até de um mesmo parágrafo. Nesse sentido, observa o professor Pires Laranjeira:

O descentramento da narração conduz a uma visão mais alargada, como se a história, a diegese, se comparasse à História interpretada por vários autores. Por outro lado, nem sempre, num capítulo, existe um exclusivo narrador, permitindo uma ambiguidade ou indeterminação focalizada. (LARANJEIRA, 1995, p. 156)

As narrações feitas pelo narrador em terceira pessoa e por Alexandre Semedo se complementam no decorrer do romance, e com exceção feita aos quatro capítulos em que o primeiro narrador narra a história da família de Vilonda, todos os demais em que essas duas vozes narram, a narrativa é feita através da perspectiva dos colonos, embora haja algumas

\footnotetext{
${ }^{24}$ Ngomas - tambores.
} 
cunhas inseridas pelo autor através da polifonia constituída por meio do diálogo. No entanto, pela voz narrativa da estátua yaka, Pepetela conta a mesma história, mas sob o ponto de vista dos angolanos, construindo uma narrativa em contraponto às vozes narrativas do narrador em terceira pessoa e de Alexandre Semedo.

Yaka geralmente assume a voz narrativa na maioria dos inícios e fechamentos das cinco partes do romance e em alguns acontecimentos importantes, como os massacres das famílias de Vilonda, já abordado na parte sobre o contraponto, e do soba Mona, no qual Bartolomeu Espinha arquiteta uma verdadeira carnificina para roubar as terras do soba; a revolta do Seles; a eclosão do movimento revolucionário em 1961; a Revolução dos Cravos e a iminência da independência de Angola; e a loucura de Xandinho, provocada pelo sentimento de culpa e pelo medo de ser condenado por ter participado do massacre da família do soba Mona.

Para narrar a história angolana vista pela perspectiva daqueles que sofreram durante séculos a dominação colonial portuguesa, Pepetela se apropria e insere no discurso da estátua a metáfora da chuva, utilizada pelo poeta/presidente Agostinho Neto no profético poema "Aqui no cárcere", como imagem da independência de Angola:

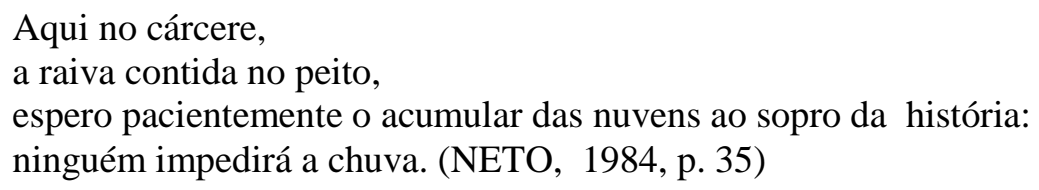

Por meio dessa metáfora, Pepetela constrói pela voz da estátua yaka uma narrativa angolanizada e em prosa poética, tendo a chuva como elemento condutor para narrar o outro lado da história contada por Alexandre Semedo e pelo narrador em terceira pessoa. Nesse sentido, essa voz surge logo no início do romance para narrar a sua versão do nascimento de Alexandre Semedo: 
Ouvi o grito de Alexandre Semedo a rasgar as entranhas da mãe e sair para a luz. Me misturei aos olhares curiosos e assustados das gazelas e ao parar súbito dos lagartos azuis fazendo sim-sim com a cabeça.

Esperava chuva única, talvez sem água, que ia ligar a boca aos olhos e às pernas e ao sexo, ainda isolados em desconfianços. Se cumpriria então o augúrio lido nos intestinos do cabrito, que confundia ruído de chuva com música estranha, nova, mas tão nossa?

Vi a boca do menino morder a terra seca. Mordeu ou beijou?

Essa mordidela-beijo era arco-íris de fim de tarde puxando a chuva da música, ou apenas o feixe de capim em que se dá o nó para amarrar a vinda da anunciada?

Estou para ver. E para contar a quem entende. Sofrendo. (PEPETELA, 1998, p. 24-25)

A partir de então, todo acontecimento histórico relevante em solo angolano vai ser relacionado à chuva pela voz de yaka, como metáfora da independência do país e elemento de ligação entre as diversas partes separadas do corpo nacional ainda em formação. Assim, no período em que se inicia a construção da ferrovia entre Lobito e o Huambo, a voz narrativa de yaka questiona:

Esse comboio vai trazer a minha música? Ou vai assoprar a chuva de música para longe, com o puf-puf e o fumo dele?

Procuro no mar, do alto da montanha, o anúncio das nuvens especiais. Nada vejo ainda. Sei, não é chuva dessa que faz o milho ter bandas. É música de água mbulumbumbando ${ }^{25}$ em gotas de cascatas, enchendo o ar de perfumes molhados, densos.

A minha boca se abriu definitivamente, igual à do menino ao nascer, para 0 sabor da terra molhada. (PEPETELA, 1998, p. 96)

No trecho final da segunda parte do romance, "Os olhos", depois de sufocada a revolta do Amboim pelas forças coloniais, a voz da estátua yaka narra os últimos acontecimentos da guerra preta, denunciando o trabalho forçado a que os nativos eram submetidos, o roubo das suas melhores terras, a violação de suas filhas, os altos impostos cobrados pela colônia e a cooptação dos bailundos pelos portugueses, antes revoltosos e agora aliados na destruição dos seles e dos sumbes, ao mesmo tempo em que reforça a certeza de que somente a chuva anunciada poderia acabar com as revoltas em território angolano.

\footnotetext{
${ }^{25}$ Mbulumbumbando - tocando mbulumbumba (berimbau)
} 
Naquele Outubro de 1917, os sumbes e os seles perderam os sonhos deles, aquecidos no calor das fogueiras, a olhar os frutos vermelhos do café. Acabar o trabalho forçado nas roças? Haka, sonhos! Recuperar as terras vermelhas boas para o café? Haka, sonhos! Acabar com o imposto de cubata? Acabar com as razias, as rusgas, as violações das meninas? Haka, sonhos! Tudo sonhos, como antes os dos bailundos, como antes os do mundombe. Canhão veio, destruiu os sonhos. Canhão com bailundos a puxar agora por ele contra os sumbes e os seles.

(...)

As montanhas ficaram queimadas? Mentira deles. A fogueira não queima montanha, só a lambe, a fogueira não queima o verde das plantas, só os castanhos. A mentira é deles.

(...) Os pés estão gretados, unhas arrancadas pela palmatória, mas tem aquela força nos olhos. Nos olhos, os sumbes e seles guardaram a força da terra vermelha, iluminada pela fogueira que apagou em Outubro.

Apagou mesmo?

Queimada não apaga com banda de canhão, nem com traições nas falas. Só a minha chuva de música, criação nossa, pode apagar de vez essa fogueira que fica escondida nas brasas, sempre avivadas pelo sopro da injustiça. Deixa só! O vermelho das brasas guardadas está escondido nos olhos dos sumbes e dos seles, leão pronto a saltar na anhara.

Assim danço no komba, no alto da montanha. ((PEPETELA, 1998, p. 156157)

Os acontecimentos de fevereiro de 1961, que marcam o início do movimento revolucionário angolano e que causaram pânico no sapalalo dos Semedo, são encarados pela voz narrativa de yaka como a sua própria festa da puberdade, ou seja, é o rito de passagem final para a independência. No entanto, o lento desenrolar dos acontecimentos depois de um começo avassalador, provocado em grande parte pela violenta reação colonial, que faz com que a independência não chegue imediatamente e ainda leve mais 14 anos para acontecer, provoca o questionamento feito pela voz narrativa a partir do segundo parágrafo do capítulo 4, da parte "O sexo", do fato de a chuva não ter vindo forte, embora permaneça a certeza de que os orvalhos e os chuviscos que caíram ainda se transformarão na chuva torrencial tão aguardada que chegará muito em breve, conforme podemos verificar no trecho abaixo:

Danço a minha própria festa da puberdade. (...) Os intestinos do cabrito abertos e sanguinolentos escreviam, a chuva de música chegou. Os fumos 
brancos das penas de capota $^{26}$ queimadas apontavam a chuva. E chuva choveu?

Chuviscou só orvalhos nas hastes de capim verde-tenrinho a furar a terra. Orvalhos nas ruas de Luanda, nos muros da Casa de Reclusão, da Sétima Esquadra, orvalhos de Luanda. Chuviscou nos Dembos, Território Livre de Nambuangongo, Quitexe, Quibaxe, Quiculungo, Damba, Tamboco, notas musicais nortistas. Mas a chuva de lavar a terra vermelha, a chuva de torrentes barrentas levando casas e carros e gentes para o mar, a música limpadora de rancores e de medos, a chuva estava aonde? O cabrito se enganou nos seus enrolados intestinos? Não pode. As penas pretas pintalgadas de branco da capota se enganaram? Não pode. Os mistérios do mundo ao contrário levaram a dançar quando devia me fechar em casa. A dança interdita ia endireitar o mundo? A dança antes da música. $\mathrm{O}$ ser antes da criação.

(...)

A chuva anunciada por Mutu-ya-Kevela e seus equívocos seguidores era só esse chuvisco? Os olhos dos sumbes e dos seles que se misturaram aos olhos dos cuvale sem gado traziam apenas gotas esparsas. No Norte, muitos outros sumbes e cuvale tinham nos olhos a mesma certeza de torrenciais trovoadas, mas a vaga? (PEPETELA, 1998, p. 217-272)

A tão esperada chuva, que leva casas, carros e gentes para o mar, numa alusão metafórica à fuga dos colonos portugueses, chega na última parte do romance, "As pernas", que aborda o período da independência angolana em 1975. Os chuviscos e orvalhos que metaforizam as primeiras revoltas anticoloniais (dos bailundos, seles, sumbes e cuvales) se transformam numa chuva torrencial que cai sobre o território angolano, trazendo com ela a certeza da independência política e do nascer de uma pátria angolana, consumando, dessa forma, a previsão lida nos intestinos do cabrito e na fumaça das penas queimadas da galinha capota.

Os intestinos do cabrito, quando abertos por homem prudente e sábio, nunca se enganam. Duvidavam? Então não estão aí as chuvas, aquelas mesmas começadas nos olhos de bailundos e sumbes e seles e cuvales e outros olhos lá do Norte e o Leste e as danças e no batuque de noites sem fim lavados mesmo para o outro lado o mar?

Foram os orvalhos e chuviscos primeiros, depois as chuvas dispersas por Cabinda e o imenso Leste então, quando tudo estava quieto ao sol e até o lagarto azul tinha preguiça de os dizer sim-sim, com a cabeça pesada de meio-dia, quando os siripis se encolhiam debaixo das folhas procurando sombra, quando a paz mentirosa parecia enlanguescer os músculos e as vontades, estourou aquele trovão medonho que para muitos era música de marimba anunciando água fresquinha a cair gota a gota de cascatas

\footnotetext{
${ }^{26}$ Capota - galinha d'angola.
} 
intermináveis ou era cadência frenética de mbulumbumba a despertar os homens e o gado, e para outros foi só isso mesmo, um trovão medonho de estarrecer, como Bartolomeu Espinha que gritou esses capitães já me foderam, traidores da merda, a brincarem aos golpes de Estado, e o rádio que repetia não se sabe bem o sucedido em Lisboa, mas já o trovão tinha chamado as nuvens grossas e os batuques refloresceram nos cânticos coletivos de bater palmas, agora é que era, e as armas lá na mata dispararam saraivadas para o ar festejando a vitória coletiva e ninguém que segurava mais o processo pois não tinha mais quem quisesse lutar para travar o avanço impetuoso das nuvens e as faíscas brilhavam nas noites e o batuque aumentava e os cantos aumentavam e as nuvens vinham e eu danço por cima do Pundo, da Chela, das Mundas, do Moco, do Mucaba e das chanas orientais, chuva diferente caindo que não provocava enxurradas na terra sequiosa, só abria os sorrisos e a música das flores silvestres... (PEPETELA, 1998, p.321)

O “trovão medonho”, uma metáfora da Revolução dos Cravos ocorrida em Portugal em abril de 1974, pondo por terra a ditadura portuguesa do Estado Novo, anuncia a chegada da chuva, a independência política angolana, trazendo alegria para os angolanos e medo e apreensão para os colonos portugueses exploradores, como Bartolomeu Espinha e tantos outros que tiveram que fugir do país, aterrorizados pela possibilidade de terem que pagar pelos crimes cometidos durante décadas de exploração colonial.

Dessa forma, através da voz da estátua yaka, Pepetela apresenta uma outra versão da história, comprometida com o povo angolano e seus valores culturais, conforme fica bem nítido nos trechos que citamos anteriormente, por meio de

... um discurso essencialmente poético, repleto de referências à mitologia africana, que estabelece um contraponto ao discurso e à acção do colonizador, pois resgata os valores e as práticas culturais da população nativa e recupera o passado de resistência do povo angolano contra o invasor colonial. (MARTIN, 2002, p. 298)

A polifonia é um dos principais recursos narrativos utilizados por Pepetela, não só em Yaka mas também na grande maioria de suas outras obras literárias, para fazer aquilo que Alfredo Bosi (2008, p. 120) chama de "translação da esfera ética para a estética", pois ela lhe permite contar outras histórias, contar a mesma história sob uma outra perspectiva, dar voz àqueles que nunca tiveram voz e mostrar as contradições políticas e sociais através do 
contraste de atitudes e pensamentos divergentes. Por essa razão, a polifonia é um dos principais elementos que fazem Yaka ser uma obra também engajada no plano estético.

\subsubsection{A metaficção}

No romance Yaka não temos nenhuma personagem-escritor que esteja escrevendo ou planejando escrever um livro. No entanto, do meio para o final da narrativa tomamos conhecimento que o patriarca Alexandre Semedo passou a escrever as suas memórias após a morte da esposa Donana.

Depois de Donana falecer, começou a escrever as suas memórias. Em forma de conversas para a estátua yaka. Leu tudo o que pôde encontrar sobre a história da região e não só. Também livros etnográficos sobre o leste e o Norte. Era raro o que aparecia no mercado, havia talvez muita coisa longe, inacessível para ele. Também não era um drama. Interessava-lhe explicar como vivera o pai dele e como ele viveu. Para isso não precisa muita História. Durante quatro anos escreveu regularmente, mas muito lentamente, na média de duas frases por dia. Cada palavra puxava uma recordação, uma ideia, e se perdia nos meandros da memória. Depois vinha uma ideia e esta levava-o a filosofar sobre coisas mais gerais e sentia a necessidade de conhecer melhor os detalhes dum facto passado fora do seu conhecimento directo ou um costume dos povos da região. O que nasceu como uma biografia modesta, para consumo exclusivo da família, começou a ganhar um âmbito mais geral, que o ultrapassava. Além disso, não podia pôr tudo o que passara ou que sentira. Era para ser lido pelos netos, depois da morte dele. Que imagem de homem ia deixar? Poderia por exemplo contar o seu amor infeliz por Njaya? Nas páginas lidas e relidas não se reconhecia. Era só uma parte dele. A parte visível, a que queria mostrar. E depois foi desinteressando do projecto, porque os netos não mereciam o esforço. (...) $\mathrm{E}$ depois? Escrever a história da família? Ou apenas as suas ideias sobre a história da família? Todos os dias passava um momento a olhar para as páginas esborratadas de azul-violeta, mas já sem lhes acrescentar nada. As memórias paravam com a revolta do Seles, de que ele hoje tinha opinião radicalmente diferente. Como pudera ter aquelas ideias? Foi escrevendo que se separou delas e hoje as sentia como punhaladas do passado. Nisso reconhecia o mérito do seu esforço. Mas era exclusivamente para ele, pois se tratava de ter uma visão diferente do antigamente. Não ia convencer ninguém. (PEPETELA, 1998, p. 277-278) 
Nessa altura da narrativa já é possível perceber que grande parte do romance que estamos lendo, os trechos narrados em terceira pessoa pelo narrador onisciente e em primeira pessoa por Alexandre Semedo, é, na verdade, parte integrante da autobiografia escrita pelo patriarca dos Semedo, pois as semelhanças existentes entre o romance e aquilo que Alexandre diz ter escrito são grandes.

Alexandre afirma que o objetivo da escrita de suas memórias era mostrar como ele e o pai viveram no tempo colonial, de modo a escrever a história da família e ao mesmo tempo fazer uma reflexão sobre ela. Esse propósito coincide com um dos objetivos de Pepetela para a escrita Yaka, que era mostrar como viveram e como pensavam os colonos, de forma a realizar uma análise da sociedade colonial angolana. Também há uma coincidência nos processos de escrita da autobiografia da personagem e do romance, pois, além da memória, tanto Alexandre Semedo quanto Pepetela se valem da pesquisa de livros históricos e etnográficos sobre a região. E, ainda, o processo de escrita para Alexandre serviu-lhe para reflexão e compreensão dos acontecimentos históricos que viveu, tornando-se fundamental para a sua angolanização, fato que lembra a declaração de Pepetela a Michel Laban (1991) de que a escrita literária serve-lhe para a refletir e compreender melhor determinada situação.

Acrescentando-se a essas semelhanças a informação dada pela personagem de que grande parte do livro de memórias consiste em conversas dela com a estátua, algo que vínhamos presenciando no decorrer da romance, nos trechos narrados em primeira pessoa por Alexandre Semedo, podemos considerar, sem nenhum risco, Yaka também como um romance metaficcional, que chama "a atenção para o seu status ficcional e para seus próprios procedimentos de composição", (LODGE, 1992, p. 206), ou, como diz Hayden White (1994) para a sua natureza de artefato literário.

Dessa forma, a autobiografia de Alexandre Semedo citada na narrativa configura-se numa mise em abyme, correspondendo "a inserção de uma narrativa dentro da outra que 
apresenta uma relação de semelhanças com aquela que contém” (DÄLLENBACH, 1977, p. 18). A utilização dessa estratégia narrativa por Pepetela serve para mostrar o lento processo de angolanização que Alexandre Semedo sofre no decorrer do romance, pois, se no início da narrativa ele compartilhava o mesmo pensamento dos outros colonos, chegando, inclusive a pensar em matar todos os negros para ficar livre do medo e a apoiar a iniciativa de alguns colonos de assassinar covardemente nativos prisioneiros de guerra, conforme o relato feito por Tuca da guerra preta do Amboim, no final ele repudia todas essas ideias que teve no passado e faz a opção por Angola no momento da independência, quando toda a família resolve fugir para a África do Sul, morrendo em paz consigo mesmo e com a terra que ele ansiava por compreender.

A presença dessa estratégia narrativa em Yaka faz com que o romance contenha uma das seis características identificadas por Seymour Menton (1993, p. 43) no novo romance histórico, que é "a metaficção ou comentários do narrador sobre o processo de criação", e da maneira como ela foi articulada pelo autor permite entrever o processo de criação e desenvolvimento da narrativa, procedimento que Linda Hutcheon (1984) denomina de "mimese do processo", que colabora também para o engajamento do romance no plano estético, em total consonância com a escolha ética e o projeto literário do escritor. 


\section{CONCLUSÃO}

Conforme vimos no decorrer desta tese, Erico Verissimo e Pepetela são escritores engajados, comprometidos com as causas humanas e contrários a qualquer tipo de repressão, violência e cerceamento de liberdade, e por isso seus projetos literários comportam, acima de tudo, um projeto ético fiel às suas visões de mundo e aos seus compromissos social e humano, que é intensificado pelo projeto estético que o acompanha, de modo que ambos conseguem aliar literatura de intervenção social com alta elaboração estética. Desse modo, para eles a escrita literária é uma ação que visa "representar o mundo e testemunhar sobre ele", recuperando-o e mostrando-o tal como ele é, para desvendá-lo e oferecê-lo à reflexão do leitor, com os objetivos de testemunhar e explorar o paradoxo que é o homem no mundo (SARTRE, 2006, p.47-49) e também "promover a liberdade humana e o conhecimento" (SAID, 2005, p. 31).

Sob esse aspecto, os seus textos literários possuem uma função social, que é ao mesmo tempo humanizadora e política, pois buscam oferecer ao leitor, além da fruição da boa história contada, algo que possa despertar consciências e colaborar para a ocorrência de significativas mudanças sociais que por sua vez contribuam para o bem-estar do homem. Por isso, eles colocam em suas obras literárias o conjunto dos valores nos quais acreditam e pelos quais se definem (DENIS, 2002, p. 46). Nesse sentido, lembramos duas declarações dadas pelos dois romancistas sobre a escrita literária. Erico Verissimo, numa entrevista a Jorge Andrade afirma sobre o papel do romancista:

Sempre achei que o menos que um escritor pode fazer, numa época de violência e injustiças como a nossa, é acender a sua lâmpada, fazer luz sobre a realidade de seu mundo, evitando que sobre ele caia a escuridão, propícia aos ladrões e aos assassinos. Segurar a lâmpada, a despeito da náusea e do resto. Se não tivermos uma lâmpada elétrica, acendamos o nosso toco de vela ou, em último caso, risquemos fósforos repetidamente, como um sinal de que não desertamos nosso posto. (ANDRADE, 1972, p .9) 
E Pepetela, em entrevista à professora Jane Tutikian, ao ser questionado sobre a confluência entre literatura e ideologia e o papel do escritor, responde:

Não me parece possível o escritor separar a sua ideologia da sua prática de escritor. É claro que se pode pôr na boca dos personagens tudo o que se queira e a literatura em parte é isso mesmo, uma discussão/confronto entre personagens de ideologias diferentes, mesmo se elas não sabem o que isso quer dizer. Mesmo os escritores mais desideologizados têm uma ideologia e um papel na sociedade. (TUTIKIAN, 2009, p. 209)

Dessa forma, são muitas as afinidades ideológicas entre Pepetela e Erico Verissimo, que por sua vez levaram também a uma afinidade estética entre os dois escritores na configuração de suas narrativas de fundação. Conforme já vimos no primeiro capítulo, essas afinidades foram geradas pela nova articulação entre o elemento literário e o social, que a partir das primeiras décadas do século $\mathrm{XX}$ envolveu mais o aspecto político e tornou a literatura mais compromissada com a realidade que lhe dava origem, levando os escritores a "uma tomada de posição refletida, consciência lúcida do escritor de pertencer ao mundo e vontade de mudá-lo" (DENIS, 2002, p. 37-38), diante de um contexto histórico desolador, de guerras e crises sociais, como foi a primeira metade do século XX. E assim a literatura passou a ser também um meio de "tomar partido" contra todas as injustiças, violências e misérias que emergiam desse cenário caótico, tornando-se engajada, conforme teorizou Sartre (2006), criando-se então um novo modo de se fazer literatura de intervenção social, que por sua vez provocou um grande diálogo intertextual entre romancistas de todas as nacionalidades por causa da afinidade ideológica e dos laços de solidariedade gerados entre eles, proporcionando o compartilhamento de temáticas e estratégias narrativas que passaram a ser de uso comum.

É nessa tradição da literatura de intervenção social, nos moldes como foi configurada no século $\mathrm{XX}$, que se filia a literatura de Erico Verissimo e Pepetela. O primeiro foi contemporâneo do surgimento dessa literatura, fazendo parte dos escritores engajados de língua portuguesa que foram formados na mesma atmosfera ideológica da frente popular 
antifascista que contagiou os intelectuais do mundo todo na década de 30, conforme observa Benjamin Abdala Júnior (2007), sendo forjados num dos mais turbulentos períodos históricos que a humanidade teve. Já Pepetela, cuja carreira literária começa na década de 60, podemos considerá-lo como herdeiro direto da tradição da literatura engajada em língua portuguesa que começou no Brasil nos anos 30, chegou a Portugal na década seguinte e um pouco mais tarde serviu como modelo a ser seguido pelos escritores das nascentes literaturas de Angola, Cabo Verde e Moçambique, conforme atestam várias declarações de escritores portugueses e africanos que citamos nos capítulos anteriores. Nesse sentido, concordamos inteiramente com a afirmação feita pelo professor Edvaldo Bergamo (2008, p. 199) de que "o projeto literário dos anos 30 e 40 do século XX de revalorização do realismo e de aprofundamento da questão social (...) deixou marcas que foram aproveitadas e/ou reformuladas pela posteridade." Dentre elas estão, a nosso ver, algumas marcas temáticas e formais da literatura do romancista brasileiro (a narrativa de fundação, a saga familiar, a metaficção, o contraponto e a polifonia) que foram apropriadas, reformuladas e adaptadas pelo escritor angolano ao seu projeto literário e ao contexto da literatura angolana.

No entanto, embora a nossa pesquisa seja norteada pela tese de que a afinidade ideológica existente entre Pepetela e Erico Verissimo tenha levado o escritor angolano a incorporar ao seu projeto literário alguns elementos temáticos e formais utilizados pelo brasileiro, conforme procuramos demonstrar em nossa análise e argumentação, a relação entre eles não se alimenta apenas na semelhança nos pontos em que mencionamos, mas também nas diferenças que há entre suas obras. A começar por seus projetos literários, que são construídos de acordo com o contexto histórico-social em que estão inseridos, pois lembramos com Antonio Candido (1972, p. 79) que o texto literário se forma a partir do contexto, que dá "lastro às obras e as amarram ao mundo onde vivemos" (CANDIDO, 1972, 2000), de forma 
que uma obra literária é fruto da confluência entre a iniciativa individual do escritor e as condições sociais do ambiente em que está inserido.

Dessa forma, à parte a grande afinidade que há entre os dois escritores, com a confluência, no plano ideológico, da ideologia humanista e do compromisso social e humano que ambos apresentam em seus projetos literários, e no plano estético, da semelhança existente entre as estruturas narrativas de seus romances de fundação, através do uso de temáticas e estratégias narrativas comuns; a matéria literária abordada em seus romances, mesmo naqueles em que há confluência estética, é totalmente diversa, sendo também que os seus projetos literários apresentam significativas diferenças em relação ao desenvolvimento.

Comecemos por seus projetos literários. Erico Verissimo inicia a sua trajetória literária nos anos 30 procurando a melhor forma de "realizar um corte transversal da sociedade", através do qual pudesse revelar ao leitor a engrenagem social e seus mecanismos, de modo que mostrasse o homem na sua dinâmica social e o indivíduo em sua humanidade (CHAVES, 2001). Por essa razão, os seus primeiros romances são ambientados em cenários urbanos, seja Porto Alegre ou a fictícia Jacarecanga, espaços que lhe permitia transitar por diversos estratos sociais, desde as classes mais baixas até as mais abastadas, embora o escritor se fixasse mais na representação da classe média baixa, cujas preocupações se baseavam na questão econômica que impunha dificuldades às suas sobrevivências. Conforme o próprio escritor reconhece, as personagens dos seus primeiros livros preocupavam-se com as contas a pagar no fim do mês, o que, na verdade, era um reflexo da própria condição socioeconômica do autor, que na época se desdobrava em várias atividades durante mais de 12 horas por dia para poder sobreviver, tendo apenas os finais de semana para escrever os seus livros (BORDINI, 1997).

Excluindo-se a malograda experiência de Saga, cuja primeira parte narra a participação de Vasco Bruno na Guerra civil espanhola, todos os romances anteriores a $O$ 
tempo e o vento, mesmo sendo romances engajados em total consonância com a estética do romance social brasileiro das décadas de 30 e 40, não apresentam o teor político elevado que os seus últimos livros publicados possuem. O forte questionamento político vai figurar na obra literária de Erico Verissimo somente a partir de $O$ tempo e o vento, principalmente a partir do terceiro volume, $O$ arquipélago, e também, não por coincidência, após o escritor ocupar o cargo de Diretor do Departamento de Assuntos Culturais da União dos Estados Americanos (UEA), no período de 1953 a 1956, condição que colaborou para o seu amadurecimento político, principalmente por propiciar ao autor a vivência de situações políticas de bastidores, de ver o poder do lado de dentro, fato que certamente ajudou na elaboração de romances de forte conteúdo político, como se pode verificar nas suas últimas produções literárias.

Dessa forma, o projeto literário de Erico Verissimo, que apresenta uma visível linha de coerência do início ao fim, vai se desenvolvendo e incorporando outros elementos, tanto formais quanto de conteúdo, na medida em que o contexto sócio-histórico muda e o autor vai tendo outras vivências, e em consequência ele vai obtendo uma visão política mais alargada. Exemplos disso são os fatos de que Erico Verissimo só empreendeu a elaboração de $O$ tempo e o vento, se aventurando pela história da origem do Rio Grande do Sul, somente quando se sentiu suficientemente amadurecido para realizar tal tarefa; e também, ele que sempre teve um verdadeiro horror à violência, passar a aceitar a violência contra a violência (a violência necessária), conforme fica nítido em $O$ senhor embaixador, quando ele engaja na luta armada os intelectuais Leonardo Gris e Pablo Ortega. Nesse aspecto, no contexto do seu projeto literário, $O$ tempo e o vento ocupa uma posição central, como obra do amadurecimento do escritor que faz uma transição para um discurso político mais radical. Nesse sentido, podemos afirmar que Erico Verissimo inicia a sua trajetória com obras mais preocupadas com o aspecto 
social, passando para a preocupação histórica da formação do estado do Rio Grande do Sul, até chegar ao questionamento político nacional e internacional.

Já em relação à Pepetela, de maneira inversa à trajetória literária de Erico Verissimo em que o elemento político vai gradativamente sendo incorporado à sua obra literária até se tornar o elemento predominante nos seus três últimos romances, ele já inicia a sua carreira literária produzindo uma literatura em que o "milieu político é o cenário dominante" (HOWE, 1998, p.5), ou seja, ele já nasce escritor como um romancista em que o questionamento político é um elemento fundamental em sua obra. A razão disso já o sabemos. O contexto histórico-político-social no qual Pepetela estava inserido era totalmente diverso do contexto vivido por Erico Verissimo. Ele vivia num país que ainda era uma colônia portuguesa e por isso havia a necessidade de uma descolonização urgente e do engajamento, não só literário, mas também do engajamento na luta armada para a libertação nacional. Por isso, a guerra contra o colonialismo português e discurso anticolonial vão pautar as suas primeiras obras literárias, que iniciam o seu projeto literário, cujo tema principal, conforme já foi amplamente mencionado no decorrer desta tese, é a nação angolana, acompanhado de um constante questionamento às estruturas de poder tanto coloniais quanto pós-independência. E ao contrário de Verissimo, que só no final de sua trajetória literária incorpora a violência necessária ao seus romances, em Pepetela ela está presente desde o início, como único meio de libertar Angola do jugo colonial português.

Desse modo, Pepetela surge como escritor no período de reivindicação da independência política angolana, e como personagem atuante desse processo histórico, estando totalmente engajado na causa revolucionária, os seus primeiros romances foram escritos para não serem publicados e tinham um cunho totalmente didático, seja para ser utilizado como tex to de reforço no ensino da língua portuguesa nas escolas do MPLA, caso de As aventuras de Ngunga, seja para servir de instrumento de reflexão política do próprio 
escritor para auxiliá-lo nas aulas de formação política que dava aos guerrilheiros, como foi o caso de Mayombe, quando estava atuando diretamente no front da guerra colonial. Naquele momento, o romance de caráter político atendia melhor a uma necessidade didática urgente daquele contexto histórico e correspondia também a uma tomada de posição diante daquela realidade vivida, que durou cerca de 14 aos, período em que Pepetela viveu em situação diáspora e guerrilha.

Somente alguns anos após a independência política, depois do autor ter deixado o cargo de vice-ministro da Educação, é que ele pode começar a pensar a sério o seu fazer literário, como uma atividade sistematizada que poderia ser escrita para ser publicada. Aí então é que surgem as narrativas de fundação em seu projeto literário. Após essa estabilização do autor, e em certa medida do próprio país, apesar da guerra civil ter durado até 2002, Pepetela transita entre romances históricos (que também são de fundação), políticos, alegóricos e satíricos, e à exceção de $O$ terrorista de Berlkeley, Califórnia e $O$ quase fim do mundo, todos eles têm Angola como tema e cenário, ao mesmo tempo em que mantêm o questionamento político como uma espécie de eixo norteador do seu projeto literário que objetiva levar o seu leitor a pensar a construção de Angola.

Nesse sentido, o projeto literário de Pepetela difere totalmente do projeto literário de Erico Verissimo. O projeto de Pepetela já se inicia com uma consistente conscientização política que o atravessa do início ao fim, enquanto que o escritor gaúcho só adquire uma conscientização política mais sólida a partir da escrita de $O$ tempo e o vento. Outra diferenciação é que Erico Verissimo prioriza em seus romances a abordagem da sociedade, mas sem a preocupação da construção nacional, com exceção, é claro de $O$ tempo e o vento e em certa medida de Incidente em Antares, enquanto que em Pepetela a abordagem da sociedade angolana e a construção da nação são inseparáveis, ou seja, são duas faces de uma mesma moeda. 
Em relação à confluência estética entre a estrutura narrativa de $O$ tempo e o vento e Yaka, que norteou nosso trabalho de pesquisa, que defende a ideia de que o escritor angolano incorporou à sua literatura alguns elementos formais utilizados por Erico Verissimo na elaboração da trilogia, cabe dizer também que a semelhança é apenas formal e temática. No plano do conteúdo predomina a diferença entre as duas narrativas de fundação. O conteúdo veiculado por $O$ tempo e o vento é uma matéria literária brasileira, que, centralizada na representação do Rio Grande do Sul, aborda aspectos da sociedade, da cultura e da história brasileira em total em consonância com o projeto literário de Erico Verissimo. Do mesmo modo podemos dizer que Yaka possui uma matéria literária 100\% angolana, representando aspectos importantes da história, da cultura e da sociedade angolana, também em perfeita consonância com o projeto literário de Pepetela.

Nesse sentido, vale lembrar uma observação feita por Antonio Candido (2004) sobre o fato de uma técnica narrativa ser utilizada por vários escritores. Para o crítico brasileiro, a técnica empregada por um escritor é um instrumento de trabalho e por isso ela pode ser utilizada por mais de um deles, de forma que podem usá-la para expressar mais de um conteúdo, ou seja, se a técnica ou a forma é semelhante, os conteúdos expressados por ela podem ser diferentes. Ao encontro da observação de Candido vem o pensamento do crítico literário russo Victor Zhirmunsky (1994), para quem cada influência literária envolve a transformação social do modelo que é adotado, ou seja, a sua reinterpretação e adaptação às condições literárias e sociais, e à individualidade ideológica, psicológica e artística do autor em questão, de forma que, segundo Edvaldo Bergamo (2008), o compartilhamento da mesma série ideológica e de temas e estratégias formais semelhantes não impedem que a obra literária seja permeada por variantes locais, que devem ser observadas na comparação literária como elementos de diferenciação que a caracterizam. 
Sob esse aspecto, cabe também lembrar outra observação feita por Antonio Candido. Desta vez sobre o fato de Erico Verissimo ter se apropriado e adaptado ao seu projeto literário e ao contexto da literatura brasileira algumas técnicas narrativas originárias das literaturas de língua inglesa e francesa. Segundo o crítico brasileiro, o fato de ele ter se apropriado delas não significa de forma alguma que ele tenha feito uma mera cópia, conforme muitos acusavam o escritor gaúcho na época.

Erico Verissimo é um escritor brasileiro que fez romance especificamente brasileiro, transpondo para o plano da arte, numa linguagem bem brasileira, temas, problemas, sentimentos e personagens que são essencialmente brasileiros. Os seus recursos técnicos, os seus ângulos de visão, é que sofrem a influência de escritores estrangeiros. (CANDIDO, 2004, p. 64)

Da mesma forma, podemos considerar Yaka como um romance legitimamente angolano, escrito em língua portuguesa e numa linguagem autenticamente angolana, abordando temas, problemas, sentimentos e personagens essencialmente angolanos, encaixados numa estrutura narrativa que apresenta muitos pontos em comum com a saga de Erico Verissimo. Desse modo, Yaka difere-se de $O$ tempo e o vento por apresentar matéria literária e matéria de extração histórica angolanas, e o fato de Pepetela ter se utilizado de estratégias narrativas já utilizadas por outro escritor na sua elaboração não diminui em nada o seu valor literário e nem a torna inferior ou devedora à obra que lhe serviu de matriz.

Nesse sentido, vejamos então alguns pontos que marcam diferenças entre Yaka e $O$ tempo e o vento. Comecemos pela utilização do gênero da narrativa de fundação.

A narrativa de fundação escrita por Pepetela em 1983 e publicada em 1984, embora não seja a primeira em Angola, pois em 1979 Manuel Pedro Pacavira havia publicado Nzinga Mbandi, ela praticamente inicia uma tradição dentro da literatura angolana, cujo principal representante vai ser o próprio escritor, pois até o momento da escrita de nosso texto, além de Yaka, Pepetela já havia publicado mais três narrativas de fundação (Lueji, o nascimento dum império, A gloriosa família: o tempo dos flamengos e A sul. O sombreiro. Nesse sentido, é 
possível também afirmar que esse gênero se torna uma tradição dentro do próprio projeto literário do escritor angolano, através do qual o escritor enceta uma busca pelo mito fundador da angolanidade, conforme observamos no terceiro capítulo, que possa construir/reconstruir a nação angolana.

Quanto à narrativa de fundação de Erico Verissimo, ela se insere numa tradição já existente na literatura brasileira, iniciada por José de Alencar em 1957, quando o escritor cearense publicou $O$ guarani, dando sequência ao gênero com as publicações posteriores de Iracema, Ubirajara e As minas de prata e depois continuada no Modernismo brasileiro por Mário de Andrade com o seu Macunaíma. E depois de $O$ tempo e o vento, Erico Verissimo voltou ao gênero apenas parcialmente em Incidente em Antares, o último romance publicado pelo escritor gaúcho, onde segundo Márcia Ivana de Lima e Silva (2000), o autor realizou uma paródia da própria trilogia. É importante ressaltar também que embora O tempo e o vento adquira feições nacionais pelo diálogo que trava com a história e a política brasileira, a preocupação do autor ao escrever a obra é abordar a saga da formação do estado do Rio Grande do Sul, que é apenas uma parte da formação da nação brasileira.

Em relação à saga familiar, Pepetela utiliza essa estratégia narrativa da mesma forma com que Erico Verissimo utilizou-a em $O$ tempo e o vento, centralizando a narrativa na história de numa família fictícia, mediana, que sintetiza as peculiaridades do período histórico representado e sofre diretamente os efeitos das crises históricas abordadas, seguindo um modo de representação típico do romance histórico tradicional, conforme a teorização de Georg Lukács (1966). No entanto, a família protagonista criada pelo escritor brasileiro tem como característica a miscigenação biológica, pois seus fundadores têm origens diversas (portugueses, índios, paulistas e açorianos) pelo fato de que a origem miscigenada seria um dos principais elementos da história da formação do Rio Grande do Sul; enquanto que em Yaka Pepetela utiliza uma família de colonos portugueses, aparentemente sem nenhuma 
marca de miscigenação biológica, sendo que esta só vai acontecer quando Alexandre Semedo engravida a criada Joana, dando origem a um tronco bastardo na família Semedo. Dentro do tronco principal da família, a verdadeira mestiçagem que ocorre é a mestiçagem cultural que se dá através da angolanização do patriarca Alexandre Semedo e seu neto Joel, que estão colocados estrategicamente nos dois polos da família, como a primeira e a última geração.

Compreende-se essa opção de Pepetela, de ter uma família de colonos portugueses como protagonista ao invés de ter uma família de origem miscigenada, por conta de alguns dos objetivos da escrita da obra que, conforme ele declarou ao professor Carlos Serrano (1999), visava realizar uma análise da sociedade colonial, procurando revelar a mentalidade do colono e as marcas deixadas pela sociedade colonial na sociedade angolana contemporânea, bem como mostrar a violência do sistema colonial vista por dentro, e também mostrar a possibilidade de que alguém que fizesse parte dessa sociedade pudesse angolanizarse a ponto de participar ativamente da guerra contra os sul-africanos, como fez Joel, o último representante do ramo principal da família Semedo a permanecer em Angola após a independência.

Outra diferença entre os Terra-Cambará e os Semedo é que na narrativa de Erico Verissimo há um contraponto estabelecido entre as figuras masculinas e femininas da família protagonista, que polarizam a trilogia do início ao fim; enquanto que em Yaka a narrativa é centralizada na figura do patriarca Alexandre Semedo, tanto é que o romance começa com o seu nascimento e termina com a sua morte. Embora Alexandre seja um eterno indeciso, as figuras femininas presentes no romance (a esposa, a filha, a nora, as netas) são personagens coadjuvantes que não possuem força suficiente para contrastar com ele.

Conforme vimos no item sobre a técnica narrativa do contraponto, em $O$ tempo e o vento Erico Verissimo utiliza essa técnica para a articulação da história que se passa no sobrado, no tempo sincrônico, com as diversas histórias dos integrantes da família Terra- 
Cambará passadas no tempo diacrônico, e para a inserção de outras histórias que ficaram à margem da narrativa principal nos episódios intermediários presentes em $O$ continente e $O$ arquipélago, como, por exemplo a história dos Caré, uma família de gaúchos paupérrimos, explorados pelas classes superiores e pelo estado, que representa uma espécie de antissaga familiar em contraposição à história da família Terra-Cambará. No primeiro caso, a utilização da técnica permite a Erico Verissimo elaborar a narrativa com dois tempos históricos distintos, de forma a quebrar a linearidade da narrativa, sem, contudo, prejudicar a sua comunicabilidade; e no segundo caso, a utilização do recurso permite ao autor inserir na narrativa a história dos excluídos, dos gaúchos pobres e sem história, que ficaram à margem da história oficial, e que sofreram mais do que outros os efeitos das inúmeras guerras e conflitos armados ocorridos no Rio Grande do Sul.

Em Yaka, Pepetela utiliza o contraponto para contar a história sob a perspectiva da família cuvale de Vilonda, uma família que foi massacrada pela polícia colonial portuguesa. A introdução da história dessa família funciona na estrutura da narrativa como uma antissaga em contraste com a família Semedo, representando todos os nativos que sofreram a violência do processo colonial em Angola, tendo papel similar àquele ocupado pelos Caré em $O$ tempo e o vento de Erico Verissimo. A diferença em relação a forma utilizada pelo escritor brasileiro ocorre pelo fato de Pepetela ter ser utilizado de uma família nativa, pertencente a um povo que habita a região sul ocidental de Angola e que exerce um atividade pastora, enquanto Erico Verissimo se vale de uma família tão miscigenada que é praticamente impossível determinar com precisão quais são as suas origens. Também é fator de diferença entre as duas famílias marginais a extensão da abordagem de suas histórias. Pepetela aborda apenas um momento da família cuvale, fixado na década de 40, quando ela se cruza com a família Semedo e depois acaba dizimada como vingança pela morte de Aquiles; enquanto a família Caré figura do início ao fim da trilogia de Erico Verissimo. 
Diferentemente do escritor brasileiro, Pepetela elabora a estrutura narrativa de Yaka de forma linear, focando cinco momentos importantes da história angolana, abordados nas partes "A boca (1890/1904), "Os olhos (1917), "O coração" (1940/41), "O sexo (1961)" e "As pernas (1975)", e a única quebra da linearidade temporal que ocorre é através de uma analepse presente na início da narrativa, quando o narrador antecipa um diálogo entre Alexandre Semedo e seu bisneto Joel que só aconteceria mais de 70 anos depois, no qual o bisavô conta ao bisneto o modo como a estátua yaka veio parar na família.

Mais tarde, já no fim da vida, Alexandre Semedo contou ao bisneto Joel: - O meu pai ganhou essa estátua yaka no jogo. Já a tinha em Capangombe, quando casou. A minha mãe sempre a achou horrível com estes olhos transparentes de berlinde e estas três listas paralelas, branca, preta e vermelha. Repara, tem quase um metro de altura e corpo de homem, mas a cara é estranha, por vezes com aspecto humano, por vezes animal. O nariz batatudo parece de bêbado e dá um ar trocista ao todo. O meu pai gostava dela, era uma recordação do jogo.(PEPETELA, 1998, p. 34)

Já em relação à polifonia, além de utilizá-la através do diálogo travado entre as personagens, como faz Erico Verissimo nos dois itens em que analisamos em que o escritor gaúcho a utiliza para desmitificar a guerra e o mito da democracia racial gaúcha, Pepetela surpreende ao utilizar pelo menos sete narradores, sendo três extremamente significativos: o narrador onisciente em terceira pessoa, Alexandre Semedo e a estátua yaka. Esses três narradores misturam-se no decorrer da narrativa, sendo que, muitas vezes, fica difícil até identificar qual voz narrativa está no comando da narração, pois acontece de elas mudarem dentro até de um mesmo parágrafo. Essa multiplicidade de narradores faz com que vejamos um mesmo assunto sempre por duas ou mais perspectivas.

Dentre esses narradores, chama a atenção o modo como Pepetela constrói a narrativa pela voz da estátua yaka. Através dela, o autor conta a mesma história, mas sob o ponto de vista dos angolanos, construindo uma narrativa angolanizada e em prosa poética, em contraponto às vozes narrativas do narrador em terceira pessoa e de Alexandre Semedo, ao 
narrar o outro lado da história contada por eles. Da forma como foi elaborada, a mesma história narrada por ela se transforma numa outra história e assim essa polifonia pode ser considerada também como uma narrativa em contraponto, que em certa medida lembra as narrações feitas nos episódios intermediários de $O$ continente, por explicitar no texto a voz da consciência coletiva africana.

Quanto à metaficção, Pepetela não utiliza uma personagem-escritor como faz Erico Verissimo em $O$ tempo e o vento, com a inclusão do romancista Floriano Cambará que se revela ao final da narrativa como o escritor do romance no qual está inserido. Pepetela utiliza como recurso metaficcional as memórias que o patriarca Alexandre Semedo escreve para contar aos seus descendentes como ele e o pai viveram no tempo colonial. Assim, ao sabermos da escrita dessa autobiografia nos damos conta de que, pelo menos, uma parte do romance que estamos lendo é parte integrante das memórias do protagonista, caracterizandose uma mise em abyme.

Conforme antecipamos na introdução, Yaka não é a única obra de Pepetela que revela semelhanças com O tempo e o vento. Lueji, o nascimento dum império, romance que não pudemos analisar por conta da extensão da tese, apresenta o mesmo processo de construção da trilogia, com a utilização de dois tempos históricos (um tempo diacrônico e outro sincrônico) e duas histórias paralelas separadas por quatro séculos, se espelhando e se dialogando o tempo todo. No tempo diacrônico, que corresponde ao passado mítico, a protagonista é a rainha Lueji, e no tempo sincrônico, a bailarina Lu, uma provável descendente da rainha, que ensaia um bailado para representar a história da soberana lunda. Além dessa estrutura narrativa em contraponto com duas histórias e dois tempo históricos, essa obra também se caracteriza como uma narrativa de fundação e uma saga familiar e contém uma personagem-romancista (o escritor Dinoluan), que se revela como o autor do próprio romance no qual está inserido, tal qual Floriano Cambará de $O$ tempo o vento (1995). 
No entanto, apesar dessas semelhanças, Lueji, o nascimento dum império se diferencia totalmente de $O$ tempo e o vento e também de Yaka. A família que protagoniza a narrativa é uma família real mítica, e ao contrário dos Semedo ou dos Terra-Cambará, que sofrem as vicissitudes da história, ela é uma agente direta da história. Nesse sentido, Pepetela não faz, na abordagem do passado mítico, uma reconstituição social típica do período e da sociedade abordada, e sim utiliza a saga de uma família que detém o poder para realizar uma profunda análise do poder, uma análise que não fica restrita ao tempo passado, podendo ser alusiva ao período de vida do autor, conforme ele mesmo admite em entrevista a Michel Laban (1991). Desse modo, desaparece a forma de representação literária típica do romance histórico tradicional que permeou a escrita de Yaka e entra uma forma de representação literária característica do novo romance histórico e da metaficção historiográfica, pois além de ter uma família mítica como protagonista, que equivale a uma família histórica, e de priorizar o questionamento político, a história que se passa no tempo sincrônico questiona o tempo todo a veracidade da história do tempo mítico.

Outra grande diferença em relação ao $O$ tempo $e$ o vento, é na articulação do contraponto das duas histórias e dos dois tempos históricos. Na trilogia de Erico Verissimo a mudança de história e de tempo histórico se dá através de uma mudança de capítulo, e em Lueji, o nascimento dum império, a mudança tanto de história quanto de tempo histórico acontece na maioria das vezes no mesmo parágrafo sem que o leitor sinta o salto por sobre os séculos que os (as) separam, conforme podemos verificar no trecho abaixo:

Timóteo foi embora, prometendo voltar amanhã. Marina descolou da janela, pôs um velho disco de Elias dia Kamezu, vou estudar. Lu puxou o caderno que estava na cabeceira, se pôs a escrever. Sons de marimba e imagens de chanas amarelecidas se baralhavam nas palavras. Talvez também sons amortecidos de palmas batidas ritualmente. Foi isso que despertou Lueji, sentada sozinha na sala de audiências. Levantou vivamente a cabeça e à sua frente estava Kandala, o advinho, saudando. (PEPETELA, 1997, p. 48) 
Depois de Lueji, o nascimento dum império, Pepetela volta a publicar outra narrativa de fundação em 1997, com A gloriosa família: o tempos dos flamengos. Nessa obra, que aborda o período da invasão holandesa em Luanda, no século XVII, o autor angolano volta a utilizar o recurso da saga familiar, mas se afasta totalmente do modelo estrutural de narrativa de fundação de Erico Verissimo. Na última narrativa de fundação publicada por Pepetela, $A$ sul. O sombreiro, publicado em setembro de 2011 em Portugal, ele retoma o uso da técnica narrativa do contraponto para inserir a história do aventureiro Carlos Rocha em contraposição à história do protagonista Manuel Cerveira Pereira, ex-governador da colônia de Angola e fundador de Benguela, e mantém a polifonia narrativa através dos diversos narradores, algo que lhe é característico. Mas, a exemplo de A gloriosa família, manteve-se afastado do modelo de Verissimo.

Dessa forma, acreditamos que Pepetela tenha se apropriado do modelo de narrativa de fundação de Erico Verissimo, incorporando e adaptando ao seu projeto literário algumas estratégias de composição utilizadas pelo escritor gaúcho em $O$ tempo e o vento, num período de construção e afirmação da literatura angolana e também de início de carreira do próprio autor, pois foi somente a partir daquele período que ele pode pensar melhor o seu projeto literário e se afirmar como escritor. Depois dessa fase o escritor encontrou outros caminhos para as suas narrativas de fundação.

Assim esperamos ter conseguido mostrar através de nossa análise a afinidade ideológica e estética existente entre Erico Verissimo e Pepetela, visível nas narrativas de fundação O tempo e o vento e Yaka e também em Lueji, o nascimento dum império, embora não tenhamos analisado esta última obra. 


\section{REFERÊNCIAS BIBLIOGRÁFICAS}

\section{A - DOS AUTORES:}

PEPETELA. A corda. 2 ed. Luanda: UEA, 1980. . A geração da utopia. Rio de Janeiro: Nova Fronteira, 1992. . A gloriosa família. Rio de Janeiro: Nova Fronteira, 1999. . A montanha da água lilás. 5 ed.Lisboa: Dom Quixote, 2007. . A revolta da casa dos ídolos. Lisboa: Edições 70, 1980. . A sul. O sombreiro. Lisboa: Dom Quixote, 2011. . As aventuras de Ngunga. 2 ed. São Paulo: Ática, 1981. . Contos de morte. Lisboa: Norton de Matos, 2008. . Crónicas com fundo de guerra. Lisboa: Norton de Matos, 2011. . Jaime Bunda, agente secreto. Rio de Janeiro: Record, 2003. . Jaime Bunda e a morte do americano. 3 ed. Lisboa: Dom Quixote, 2005.

_ Lueji, o nascimento de um império. 3 ed. Lisboa: Dom Quixote, 1997 . Luandando. Luanda: ELF Aquitaine, 1990. . Mayombe. São Paulo: Ática, 1982. . Muana Puó. 2 ed. Lisboa: Dom Quixote, 1995.

. Parábola do cágado velho. Rio de Janeiro: Nova Fronteira, 2005.

_ _ O cão e os caluandas. 3 ed.Lisboa: Dom Quixote, 1996. . O desejo de Kianda. 5 ed. Lisboa: Dom Quixote, 2004. . O quase fim do mundo. Lisboa: Dom Quixote, 2008. . O planalto e a estepe. 4 ed. Lisboa: Dom Quixote, 2009. . O terrorista de Berkeley, Califórnia. 2 ed. Lisboa: Dom Quixote, 2007. . Predadores. Rio de Janeiro: Língua Geral, 2008. 
. Yaka. 4 ed. Lisboa: Dom Quixote, 1998.

VERISSIMO, Erico. Caminhos cruzados. 30 ed. São Paulo: Globo, 1995a. . Clarissa. 50 ed. São Paulo: Globo, 1995b.

_ Fantoches e outros bichos. 13 ed. São Paulo: Globo, 1995c.

_. Incidente em Antares. 25 ed. São Paulo: Globo, 1995d. . Música ao longe. 32 ed. São Paulo: Globo, 1995e. . Noite. São Paulo: Globo, 1995f.

. O arquipélago. 18 ed. Vol. I, II e III. São Paulo: Globo, 1995g.

. O continente. 34 ed. Vol. I e II. São Paulo: Globo, 1995h . O resto é silêncio. 21 ed. São Paulo: Globo, $1995 \mathrm{i}$.

. O retrato. 18 ed. Vol. I e II. São Paulo: Globo, 1995j.

. O prisioneiro. Porto Alegre: Globo, 1970.

. O prisioneiro. 12 ed. São Paulo: Globo, 19951.

. O senhor embaixador. 14 ed. São Paulo: Globo, 1995m.

. Olhai os lírios do campo. 71 ed. São Paulo: Globo, 1995n.

. Saga. 15 ed. São Paulo: Globo, 1995 o.

. Solo de clarineta. vol. 1. São Paulo: Globo, 1995p.

. Solo de clarineta. vol. 2. Porto Alegre: Globo, 1976.

.Um lugar ao sol. 30 ed. São Paulo: Globo, 1995q.

\section{B) TEÓRICA-CRÍTICA}

ABDALA JÚNIOR, Benjamin. A escrita Neo-realista. São Paulo: Ática, 1981. . . De vôos e ilhas: literatura e comunitarismos. Cotia: Ateliê Editorial, 2003. . Literatura, história e política. 2 ed. Cotia: Atelê Editorial, 2007. 
- Benjamin. Notas sobre a utopia em Pepetela. In CHAVES, Rita; MACEDO, Tânia (orgs.). Portanto... Pepetela. Luanda: Edições Chá de Caxinde, 2002, p. 197-2004.

AGUIAR, Flávio; VASCONCELOS, Sandra Guardini T (orgs.). Ángel Rama: literatura e cultura na América Latina. Trad. Rachel La Corte dos Santos e Elza Gasparotto. São Paulo: Edusp, 2001.

AINSA, Fernando. La nueva novela histórica latinoamericana. Plural, 240(82-85), México,

ALMEIDA, Antonio Ramos. O romance brasileiro contemporâneo através de seus principais intérpretes. Sol Nascente. Porto, dez. 1965.

ALONSO, Amado. Ensayo sobre la novela histórica. Madrid: Gredos, 1987.

ALÓS, Anselmo Peres. As fronteiras internas da nação: pensando o colonialismo a partir da literatura angolana. Cadernos do IL, v. 2, n. 35. 2007.

ALTHUSSER, Louis. Aparelhos ideológicos do estado. 10 ed. Trad. José Evangelista e Maria Laura Viveiro de Castro. Rio de Janeiro: Graal, 2010.

ALVES, Maria Thereza Abelha. O desejo de Kianda: crônica e efabulação In CHAVES, Rita; MACEDO, Tânia (orgs.). Portanto... Pepetela. Luanda: Edições Chá de Caxinde, 2002, p. 2005-218.

ALVES, José Édil de Lima (org.). Erico Verissimo: provinciano e universal. Canoas/RS: Editora Ulbra, 2006.

ANDERSON, Benedict. Comunidades imaginadas. São Paulo: Companhia da Letras, 2008.

ANDERSON, Perry. Trajetos de uma forma literária. Novos estudos CEBRAP. São Paulo, $\mathrm{n}^{\circ}$ 77, p. 205-220, março de 2007.

ANDRADE, Fernando Costa. Literatura angolana (opiniões). Lisboa: Edições 70, 1980.

ANDRADE, Jorge. O galho da nespereira. In. CHAVES, Flávio Loureiro (org.). O contador de histórias: 40 anos de vida literária de Erico Verissimo. Porto Alegre: Globo, 1972. p. 1-15.

ARISTÓTELES. Arte retórica e arte poética. Trad. Antônio Pinto de Carvalho. 16 ed. Rio de Janeiro: Ediouro, 1998.

ATHAYDE, Tristão. Erico Verissimo e o antimachismo. In. CHAVES, Flávio Loureiro (org.) O contador de histórias: 40 anos de vida literária de Erico Verissimo. Porto Alegre: Globo, 1972. p. 86-102.

BAKHTIN, Mikhail. Problemas na poética de Dostoievski. Trad. Paulo Bezerra. São Paulo: Forense, 1997.

Questões de literatura e estética (A teoria do romance). 4 ed. Trad. Aurora Fornoni Bernardini. São Paulo: Edunesp, Hucitec, 1998. 
BARTHES, Roland. O grau zero da escrita. 2 ed. Trad. Mário Laranjeira. São Paulo: Martins Fones, 2004.

BASTOS, Alcmeno. A história foi assim o romance político brasileiro nos anos 70/80. Rio de Janeiro: Caetés, 2000.

BEAUVOIR, Simone. La force des chose. Paris: Galimard, 1963.

BENJAMIN, Walter. Magia e técnica, arte e política. Trad. Sérgio Paulo Rouanet São Paulo: Brasiliense, 1985.

BERGAMO, Edvaldo. Ficção e convicção: Jorge Amado e Neo-realismo português. São Paulo: Editora da Unesp, 2008.

BHABHA, Homi. O local da cultura. Tradução de Myriam Ávila, Eliana Lourenço de Lima Reis e Glâucia Renate Gonçalves. 5 e. Belo Horizonte: Ed. UFMG, $2010 .$.

BORDINI, Maria da Glória (org.). A liberdade de escrever: entrevistas sobre literatura e política. Porto Alegre: Editora da UFRGS, EdPUCRS, 1997.

BORDINI, Maria da Glória Bordini (org). Lukács e a literatura. Porto Alegre: EDIPUCRS, 2003.

Caminhos cruzados e a crítica literária. Travessia, n. 11, jul/dez. de 1985, p. 22-35.

. . Do moderno ao pós-moderno. Cadernos de Literatura Brasileira, n. 16, nov. 2003, p. $141-157$.

BORDINI, Maria da Glória; ZILBERMAN, Regina (Orgs.). O tempo e o vento história, invenção e metamorfose, Porto Alegre: EDIPUCRS, 2004.

BOSI, Alfredo. Literatura e resistência. São Paulo: Companhia das Letras, 2008.

BRAGA, Adolfo. Prisioneiros. In. BORDINI, Maria da Glória (org.). A liberdade de escrever: entrevistas sobre literatura e política. Porto Alegre: Editora da UFRGS, EdiPUCRS, 1997, p. 27-33.

CANDIDO, Antonio. A educação pela noie e outros ensaios. 5 ed. Rio de Janeiro: Ouro sobre Azul, 2006.

Literatura e sociedade. 8 ed. São Paulo: T. A. Queiroz, 2000.

$77-92$.

A literatura e a formação do homem. Ciência e Cultura. v. 9, n. 24. 1972, p.

Brigada Ligeira. 3 ed. Rio de Janeiro: Ouro sobre Azul, 2004a.

Entrevista com Antonio Candido. In. PESAVENTO, Sandra et. al. (org.). Erico Verissimo: o romance da história. São Paulo: Nova Alexandria, 2001, p. 11-18. 
Erico Verissimo de trinta a setenta. In. CHAVES, Flávio Loureiro (org.) O contador de histórias: 40 anos de vida literária de Erico Verissimo. Porto Alegre: Globo, 1972b, p. 4051 . p. 105-113.

Literatura, espelho da América? Remate de Males. Campinas. número especial, 1999, . O discurso e a cidade. 3 ed. São Paulo: Duas Cidades, Rio de Janeiro: Ouro sobre Azul, 2004b.

CARPENTIER, Alejo. Literatura e consciência política na América Latina. Trad. M. J. Palmeirim. Lisboa: Dom Quixote, 1971.

CESAR, Guilhermino. O romance social de Erico Verissimo. CHAVES, Flávio Loureiro (org.) O contador de histórias: 40 anos de vida literária de Erico Verissimo. Porto Alegre: Globo, 1972, p. 52-70.

CHAGAS, Wilson. 1999. Mundo velho sem porteira. 2 ed. Porto Alegre: Movimento, 1999.

CHAVES, Flávio Loureiro (org.) O contador de histórias: 40 anos de vida literária de Erico Verissimo. Porto Alegre: Globo, 1972.

. O escritor e o seu tempo. Porto Alegre: Ed. UFRGS, 2001.

CHAVES, Rita. A formação do romance angolano. São Paulo: Coleção Via Atlântica, 1999.

Angola e Moçambique: experiência colonial e territórios ocupados. Cotia: Ateliê Editorial, 2005.

CHAVES, Rita; MACEDO, Tania. (orgs.).Portanto... Pepetela. São Paulo: Ateliê Editorial, 2009.

Portanto... Pepetela. Luanda: Edições Chá de Caxinde, 2002.

CORBISIER, Roland. Prefácio. In. MEMMI, Albert. Retrato do colonizado precedido pelo retrato do colonizador. Rio de Janeiro: Paz e Terra, 1967.

DÄLLENBABACH, Lucien. Le récit spéculaire: essai sur la mise em abyme. Paris: Seuil, 1977.

DENIS, Benoît. Literatura e engajamento: de Pascal a Sartre. Bauru/SP: Edusc, 2002.

DINORAH, Maria. Dona sorte ou aprendizado. In. BORDINI, Maria da Glória (org.). A liberdade de escrever: entrevistas sobre literatura e política. Porto Alegre: Editora da UFRGS, EdPUCRS, 1997, p. 35-45.

EAGLETON, Terry. A ideologia da estética. Trad. Mauro Sá Rego Costa. Rio de Janeiro: Zahar, 1993. 
ECO, Umberto. Pós escrito a O nome da Rosa. Trad. Letizia Z. Antunes e Álvaro Lorencini. 3. ed. Rio de Janeiro: Nova Fronteira, 1985.

ERVEDOSA, Carlos. Roteiro da literatura angolana. 2 ed. Lisboa: Edições 70, 1979.

ESTEVES, Anonio Roberto. Lope de Aguirre: da história para a literatura. São Paulo: FFLCH-USP, 1995, Tese de Doutorado.

FANON, Frantz. Os condenados da terra. 2 ed. Rio de Janeiro: Civilização Brasileira, 1979.

FARIA, Zênia de. Sobre a metaficção e outras estratégias narrativas em A Rainha dos Cárceres da Grécia. In. CONGRESSO INTERNACIONAL ABRALIC, 11, 2008. Anais.... Porto Alegre, 2008.

FAURI, Ana Letícia. O pensamento político de Erico Verissimo: questões de identidade e ideologia. Porto Alegre: PUCRS, 2005, Tese de doutorado.

FERREIRA, Manuel. A aventura crioula. Lisboa: Ulisséia, 1967.

FERREIRA, Vergílio. Um escritor apresenta-se. Lisboa: Imprensa Nacional/Casa da Moeda, 1981.

FIGUEIREDO, Vera Folain Da alegria e da angústia de diluir fronteiras: o romance histórico hoje na América latina. Cânones \& contextos: Anais do $5^{\circ}$ Congresso ABRALIC. Rio de Janeiro: ABRALIC, 1998. Vol. 1, p. 479-486.

FOSTER, Ernest. M. Aspectos do romance. São Paulo: Globo, 2008.

FRESNOT, Daniel. O pensamento político de Erico Verissimo. Rio de Janeiro: Edições do Graal, 1977.

GALVÃO, Walnice Nogueira, Indianismo revitado. In. Esboço de figura: homenagem a Antonio Candido. São Paulo: Duas cidades, 1979.

GENETTE, Gérard. Discurso da narrativa. Trad. Fernando Cabral Martins. Lisboa: Veja, 1976.

GOLDMANN, Lucien. A sociologia do romance. 3 ed. Trad. Álvaro Cabral. Rio de Janeiro: Paz e Terra, 1976.

GOMES, Simone Caputo. o livro policial é um pretexto. In CHAVES, Rita; MACEDO, Tânia (orgs.). Portanto... Pepetela. São Paulo: Ateliê Editorial, 2009, p. 338-346.

GRANDI, Celito de. Somos todos uns mentirosos. BORDINI, Maria da Glória (org.). A liberdade de escrever: entrevistas sobre literatura e política. Porto Alegre: Editora da UFRGS, EdPUCRS, 1997, p. 59-67.

GROSSMAN, Leonid. Dostoiévski artista. Trad. Boris Schnaiderman. Rio de Janeiro: Civilização Brasileira, 1967. 
HELENA, Lucia. Figuração e questionamento da nação em $O$ tempo e o vento. In. BORDINI, Maria da Glória (org.). Caderno de pauta simples: Erico Verissimo e a crítica literária. Porto Alegre: Instituto Estadual do Livro, 2005, p. 167-182.

HOWE, Irving. A política e o romance. Trad. Margarida Goldsztajn. São Paulo: Perspectiva, 1998.

HUTCHEON, Linda. Poética do pós-modernismo: história, teoria , ficção. Trad. Ricardo Cruz. Rio de Janeiro: Imago, 1991.

Narcissistic narrative: the metaficcional paradox. 2 ed. New York: Metheun, 1984.

JAKOBSON, Roman. Lingüística e comunicação. Trad. Isidoro Blinkstein e José Paulo Paes. 2 ed. São Paulo: Cultrix, 1974.

JAMESON, Fredric. O inconsciente político. Trad. Valter Lellis Siqueira. São Paulo: Ática, 2992.

O romance histórico ainda é possível? Novos estudos CEBRAP. São Paulo, nº 77, p. 185-203, março de 2007.

KRISTEVA, Julia. Introdução à semálise. Trad. Lúcia Helena França Ferraz. São Paulo: Perspectiva, 1974.

LARANJEIRA, Pires. Literaturas africanas de língua portuguesa. Coimbra: Universidade Aberta, 1995.

LEITE, Ana Mafalda. Janus-narrador em A gloriosa família de Pepetela, ou o poder profético da palavra narrativa. In CHAVES, Rita; MACEDO, Tânia (orgs.). Portanto... Pepetela. Luanda: Edições Chá de Caxinde, 2002, p. 139-150.

LINS, Álvaro. Os mortos de sobrecasaca: obras, autores e problemas da Literatura Brasileira. Rio de Janeiro: Civilização Brasileira, 1963.

LODGE, David. The art of ficition. London: Penguin Books, 1992.

LUCAS, Fábio. O romance de Erico Verissimo e o mundo oferecido. In. CHAVES, Flávio Loureiro (org.) O contador de histórias: 40 anos de vida literária de Erico Verissimo. Porto Alegre: Globo, 1972, p. 144-157.

LUGARINHO, Mário César. Quem quer comer lagostas? Reflexões sobre os estudos poscoloniais a partir de alguma ficção de Pepetela e Agualusa. In. CHAVRS, Rita; MACÊDO, Tania; VECHIA, Rejane (orgs.). A kinda e a missanga. São Paulo: Cultura Acadêmica; Luanda: Nzila, 2007.

LUKÁCS, George. La novela histórica. Mexico: Era, 1966.

MACÊDO, Tania. A geração da utopia. Metamorfoses. Rio de Janeiro, n. 07, ago. 2006.

MACHADO, Irene. O romance e a voz. Rio de Janeiro: Imago, 1995. 
MANTOLVANI, Rosangela Manhas. Jaime Bunda, agente secreto: a paródia do mito. In. CHAVES, Rita; MACEDO, Tânia (orgs.). Portanto... Pepetela. São Paulo: Ateliê Editorial, 2009, p. 329-337.

MARINANGELO, Célia Regina. A geração da utopia: a lição do mar. In CHAVES, Rita; MACEDO, Tânia (orgs.). Portanto... Pepetela. Luanda: Edições Chá de Caxinde, 2002, p. 311-318.

MARTIN, Vima Lia de Rossi. Formulações utópicas em Yaka, de Pepetela, e Levantado do chão, de José Saramdago. In CHAVES, Rita; MACEDO, Tânia, VECHIA, Rejane. (orgs.). A kinda e a missanga. São Paulo: Cultura Acadêmica, 2007.

. Yaka: a construção do discurso utópico. In CHAVES, Rita; MACEDO, Tânia (orgs.). Portanto... Pepetela. Luanda: Edições Chá de Caxinde, 2002, p. 293-298.

MARTINHO, Fernando. Muana Puó enigma e metamorfose. In CHAVES, Rita; MACEDO, Tânia (orgs.). Portanto... Pepetela. Luanda: Edições Chá de Caxinde, 2002, p. 293-298.

MARTINS, Wilson. A Literatura Brasileira: O Modernismo (1916-1945). Vol, VI. São Paulo: Cultrix, 1977.

Erico Verissimo em ciclos. Correio do Povo. Porto Alegre, 13 jan. 1968.

MATA, Inocência. Literatura angolana: silêncios e falas de uma voz inquietante. Mar Além, 2001.

Pepetela e a sedução da história. Metamorfoses. Rio de Janeiro, n. 07, ago. 2006.

1982.

. Literatura angolana: silêncios e falas de uma voz inquietante Coimbra: Almedina,

MEMMI, Albet. Retrato do colonizado precedido pelo retrato do colonizador. 3 ed. Trad.

Roland Corbisier e Marilza Pinto Coelho. São Paulo. São Paulo: Paz e Terra, 1989.

MENTON, Seymour. La nueva novela histórica de la América Latina. 1979-1992. México:

FCE, 1993.

MOISÉS, Massaud. Dicionário de termos literários. 15 ed. São Paulo: Cultrix, 2004.

História da Literatura Brasileira. Vol. III, 9 ed. São Paulo: Cultrix, 2009.

MONTEIRO, Adolfo Casais. $O$ romance (teoria e crítica). Rio de Janeiro: José Olympio, 1964.

OLIVEIRA, Alberto Pinto. Muana Puó. Metamorfoses, n. 07, ago. 2006.

OLIVEIRA, Maura Eustáquia. Pepetela: humor e sonho na vida de um contador de histórias.In LEÃO, Ângela Vaz. Contatos e ressonâncias: literaturas africanas de língua portuguesa. Belo Horizonte: PUC Minas, 2003, p.363-372.

POUILLON, Jean. O tempo no romance. São Paulo: Cultrix, EdUSP, 1974. 
RIAÚZOVA, Helena. Dez anos de literatura angolana. Lisboa: Edições 70, 2986.

RICOUER, Paul. Tempo e narrativa. Claudia Berliner. São Paulo: Martins Fontes, 3 v., 2010 .

ROSÁRIO, Lourenco. Pepetela: o Homero angolano. In CHAVES, Rita; MACEDO, Tânia (orgs.). Portanto... Pepetela. Luanda: Edições Chá de Caxinde, 2002, p. 255-228.

ROZÁRIO, Denira. Palavra de poeta: Cabo Verde e Angola. Rio de Janeiro: Bertrand do Brasil, 1999.

SAID, Edward. Cultura e imperialismo. Trad. Denise Bottman. São Paulo: Companhia das Letras, 2010..Trad. Milton Hatoum. São Paulo: Companhia das Letras, 2005.

Representações do intelectual: as conferências de Reith de 1993. Trad. Milton Hatoum. São Paulo: Companhia das Letras, 2005.

SALGADO, Maria Teresa. O cão e o caluandas; texto, o leitor e o mundo. In CHAVES, Rita; MACEDO, Tânia (orgs.). Portanto... Pepetela. Luanda: Edições Chá de Caxinde, 2002, p. 307-310.

SANT'ANNA, Affonso Romano de. Paródia, paráfrase \& cia. São Paulo: Ática, 1985.

SANTIAGO, Silviano. A estrutura musical no romance. In. BORDINI, Maria da Glória (org.). Cadernos de pauta simples: Erico Verissimo e a crítica literária. Porto Alegre: Instituto Estadual do Livro, 2005, p. 143-165.

SANTILLI, Maria Aparecida. Factos de vida,feitos de ficção ( Yaka, de Pepetela: história, mito e símbolo). In CHAVES, Rita; MACEDO, Tânia (orgs.). Portanto... Pepetela. Luanda: Edições Chá de Caxinde, 2002, p. 293-298.

SARTRE, Jean-Paul .Que é literatura? 3 ed.Trad. Carlos Felipe Moisés. São Paulo: Ática, 2006.

Em defesa dos intelectuais. Trad. Sérgio Góes de Paula. São Paulo: Ática, 1994.

SAVIANI FILHO, Hermógenes. O processo de colonização no Rio Grande do Sul: o caso de São Leopoldo no sécuilo XIX.. Porto Alegre: UFRGS, 2008 (Tese de Doutorado).

SCHOLES, Robert. Metafiction. In. CURRIE, Mark (org). Metafiction. New York, 1995. SCHOLES, Robert; KELLOG, Robert. A natureza da narrativa. São Paulo: MacGraw-Hill, 1977.

SCHULER, Donaldo. Teoria do romance. São Paulo: Ática, 2000.

SECCO, Carmen Lucia Tindó Ribeiro. Na curva oblonga do tempo, uma alegórica parábola. In CHAVES, Rita; MACEDO, Tânia (orgs.). Portanto... Pepetela. Luanda: Edições Chá de Caxinde, 2002, 177- 198. 
SERRANO, Carlos. $O$ romance como documento social: o caso Mayombe. Via Atlântica, n. 3,dez. 1999.

SHURMANS, Fabrice Aimé Fernadnd. O Trágico do Estado Pós-Colonial Pius Ngandu Nkashama, Sony Labou Tansi e Pepetela. Coimbra, 2012. (Tese de Doutorado)

SILVA, Márcia Ivana de Lima e. A gênese em Incidente em Antares. Porto Alegre: EDIPUCRS, 2000.

1992.

A polifonia em Erico Verissimo. Letras de Hoje, Porto Alegre, n. 87, p. 111-122,

SOMMER, Doris. Ficções de fundação: os romances nacionais da América Latina. Belo Horizonte: Editora UFMG, 2004.

SURO, Joaquim Rodriguez. Erico Verissimo: história e literatura. Porto Alegre: D.C. Luzzatto Editores, 1985.

TEIXEIRA, Valéria. A gloriosa família - o tempo dos flamengos. In CHAVES, Rita; MACEDO, Tânia (orgs.). Portanto... Pepetela. Luanda: Edições Chá de Caxinde, 2002, p. 337-348.

TELLES, Gilberto Mendonça. A retórica do silêncio: teoria e prática do texto literário. São Paulo: Cultrix, 1979.

TODOROV, Tzvetan. As categorias da narrativa literária. In. BARTHES, Roland et. al. (org.). Análise estrutural da narrativa. 4 ed. Trad. Maria Zélia Barbosa Pinto. Petrópolis: Vozes, 1976, p. 209-254.

TUTIKIAN, Jane. Entrevista com Pepetela. Organon, n. 47, jul-dez. 2009.

VELLINHO, Moysés. Um contador de histórias? In. CHAVES, Flávio Loureiro (org.) $O$ contador de histórias: 40 anos de vida literária de Erico Verissimo. Porto Alegre: Globo, 1972, p. 35-39.

VELLINHO, Moysés. Uma aventura noturna. In. BORDINI, Maria da Glória (org.).

Cadernos de pauta simples: Erico Verissimo e a crítica literária. Porto Alegre: Instituto Estadual do Livro, 2005, p. 55-63.

VIANA, Magdala França. Parábola do cágado velho: o cágado velho e o pensador. In CHAVES, Rita; MACEDO, Tânia (orgs.). Portanto... Pepetela. Luanda: Edições Chá de Caxinde, 2002, p. 327-336.

WATT, Ian. A ascensão do romance. Trad. Hildegard Feist. São Paulo: Companhia das Letras, 1990.

WEINHARDT, Marilene. O romance histórico no Sul. São Paulo: FFLCH - USP, 1995 (Tese de doutorado).

WHITE, H. Meta-história. Trad. J. L. Melo. São Paulo: EDUSP, 1990. 
Trópicos do discurso - ensaios sobre a crítica da cultura. Trad. Alípio Correia de França Neto. São Paulo: Edusp, 1994.

WIESER, Doris, O livro policial é o pretexto. Espéculo, revista de estudos literários. Madrid, fev. 2007.

WILLIANS, Raymond. Marxismo e literatura. Trad. Waltensir Dutra. Rio de Janeiro: Zahar, 1979.

YOUNG, Theodore Robert. O questionamento da história em O tempo e o vento. Lajeado:

FATEX, 1997.

ZHIRMUNSKY, Victor. Sobre o estudo da literatura comparada. Trad. Ruth Percice Nogueria. In. COUTINHO, Eduardo Faria; CARVALHAL, Tânia. Literatura comparada: textos fundadores. Rio de Janeiro: Rocco, 1994, p. 199- 214.

ZILBERMAN, Regina. História, mito, literatura. In. BORDINI, Maria da Glória; (Orgs.). O tempo e o vento - história, invenção e metamorfose, Porto Alegre: EDIPUCRS, 2004, p. 21-48.

Saga familiar e história política. In. BORDINI, Maria da Glória; ZILBERMAN, Regina (Orgs.). O tempo e o vento - história, invenção e metamorfose, Porto Alegre: EDIPUCRS, 2004, p. 141-158. 